\title{
Lithostratigraphy of the continental Devonian sediments in North-East Greenland
}

G E U S

Report file no.

22317

Henrik Olsen and Poul-Henrik Larsen

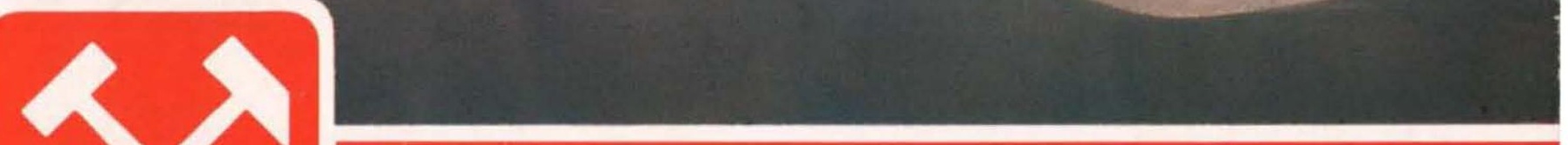

GRØNLANDS GEOLOGISKE UNDERS $\varnothing$ GELSE

GGU Bulletin 165 


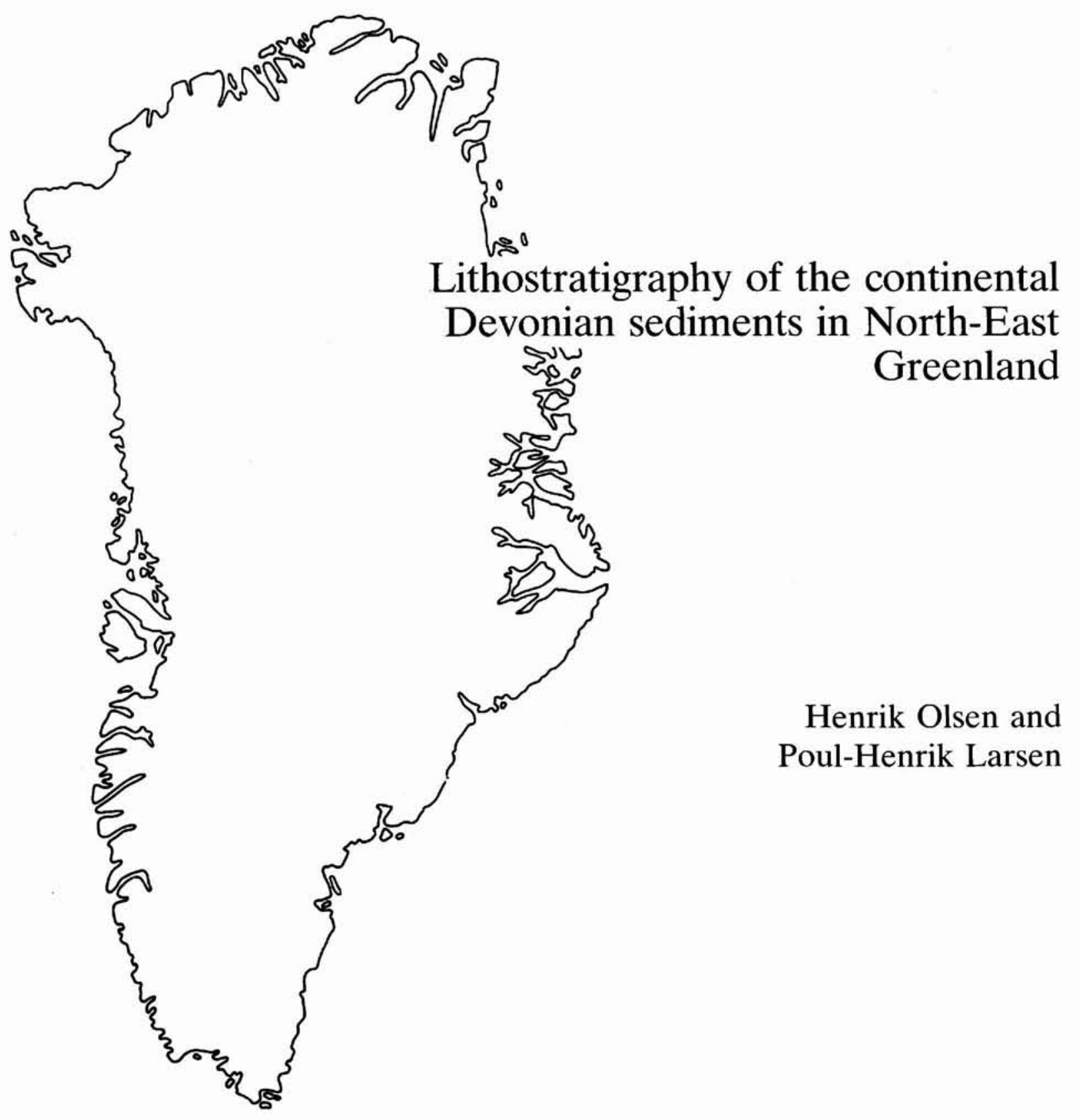


Olsen, H. \& Larsen, P.-H. 1993: Lithostratigraphy of the continental Devonian sediments in North-East Greenland. Bull. Grønlands geol. Unders. 165, $108 \mathrm{pp}$.

A new lithostratigraphy is erected for the continental Devonian sedimentary rocks in North-East Greenland based on genetic stratigraphy.

The oldest of the four groups is the upper Middle Devonian (Givetian) Vilddal Group. In the lower part it comprises the Solstrand and Kap Bull Formations (conglomerates), and in the upper part the Ankerbjergselv Formation (sandstones, siltstones, mudstones). The Solstrand Formation was deposited on a huge braidplain, whereas the Kap Bull Formation is an alluvial fan deposit. The Ankerbjergselv Formation was deposited by ephemeral and perennial rivers, flowing into terminal flood basins and lakes, respectively. Palaeocurrents in the group are generally towards the east.

The Vilddal Group is unconformably overlain by the Kap Kolthoff Group which spans from late Middle Devonian (Givetian) to Late Devonian (Famennian). It is predominantly composed by the pebbly sandstones of the Sofia Sund Formation deposited in a basin-wide braidplain environment. A number of formations occur as wedges in the Sofia Sund Formation. The Vergys Formation (conglomerates, sandstones, siltstones and mudstones) represents a braidplain grading down-current into a lacustrine environment. The Langbjerg, Barnabas Dal and Madsen Bjerg Formations (pebble free sandstones) are dominated by aeolian deposits and represent local ergs. The Snehvide Formation (conglomerates and sandstones) is mainly alluvial and was deposited as a terminal fan. The Rødebjerg Formation (mainly sandstones) is interpreted as a terminal fan enveloped in aeolian dunes. The Midnatspas Formation (alternating sandstones and mudstones) was laid down in a meander belt environment. Palaeocurrents in the Kap Kolthoff Group from both eastern and western basin margins turn southwards along the basin axis. Palaeowinds are mainly from the northeast.

The Upper Devonian (Famennian) Kap Graah Group conformably succeeds the Kap Kolthoff Group. It is composed mainly of sandstones with important conglomerates and mudstones. The lower part of the group is dominated by the pebble-free sandstones of the Udkiggen Formation, which is interpreted as an erg. Towards the west the Udkiggen Formation is replaced by the mudstones and sandstones of the Zoologdalen Formation representing a terminal fan environment.
The upper part of the group is dominated by three formations. The Rødsten Formation (conglomerates, sandstones and alternating sandstones and siltstones) represents alluvial fans with associated extensive terminal fans. The Woodward Bjerg Formation (dominated by pebble free sandstones) represents an erg. The Andersson Land Formation (sandstones alternating with mudstones) was laid down in a meander belt environment. Palaeocurrent and palaeowind patterns in the Kap Graah Group are similar to the Kap Kolthoff Group.

The Upper Devonian (Famennian) Celsius Bjerg Group rests locally conformably on the Kap Graah Group and locally unconformably on the Kap Kolthoff and/or the Kap Graah Groups. It is composed of mudstones, siltstones and sandstones with local conglomerates. The group exhibits a 'layercake stratigraphy' formed by 7 superimposed formations. The lowermost unit, the Agda Dal Formation (sandstones, siltstones and local conglomerates), represents a fluvial plain dominated by ephemeral streams. The Elsa Dal Formation (sandstones and few local conglomerates) was deposited in a fluvial environment by braided rivers. The Aina Dal Formation (mudstones and sandstones) represents a fluvial environment with perennial and ephemeral meandering rivers. The Wimans Bjerg Formation (mudstones and siltstones) was laid down in alternating alluvial mudflat and lacustrine environments. The Britta Dal Formation (mudstones and sandstones) was deposited in an ephemeral meandering river and flood basin environment. The Stensiö Bjerg Formation (sandstones with associated siltstones) was laid down in a meander belt environment. The topmost formation is the Obrutschew Bjerg Formation (muddy shales associated with limestones) laid down in a major lake. The Celsius Bjerg Group is characterized by palaeocurrents towards the north, in opposition to the underlying Kap Graah Group.

The Celsius Bjerg Group is succeeded by the Harder Bjerg Formation of uncertain age. Very little information was obtained from this unit. It is dominated by sandstones, of both aeolian and fluvial origin.

\section{Authors' addresses:}

H. O., Instituttet for Geologi og Geoteknik, Bygning 204, Danmarks Tekniske Højskole, DK-2800 Lyngby, Denmark.

P.-H. L., Mærsk Olie og Gas A/S, Esplanaden 50, DK-1263 Copenhagen K, Denmark. 


\section{Contents}

Dansk sammendrag - Imaqarnersiuineq .......... 4

Introduction

Review of research and stratigraphy of the Devonian

in North-East Greenland

Vilddal Group.

Solstrand Formation. .................... 16

Kap Bull Formation................... 23

Genvejsdalen Member ................ 26

Ankerbjergselv Formation ................ 27

Kap Kolthoff Group ..................... 32

Sofia Sund Formation .................. 39

Watson Plateau Member................ 45

Blaskbjerg Member ................. 46

Teglbjerg Member .................. 48

Vergys Formation................... 50

Langbjerg Formation.................... 52

Barnabas Dal Formation................... 54

Rødebjerg Formation .................... 57

Snehvide Formation ................... 60
Madsen Bjerg Formation ............... 61

Midnatspas Formation ................... 64

Kap Graah Group $\ldots \ldots \ldots \ldots \ldots \ldots \ldots \ldots \ldots \ldots \ldots \ldots \ldots$

Udkiggen Formation $\ldots \ldots \ldots \ldots \ldots \ldots \ldots \ldots \ldots, 72$

Zoologdalen Formation.................. 75

Rødsten Formation $\ldots \ldots \ldots \ldots \ldots \ldots \ldots \ldots \ldots \ldots$

Woodward Bjerg Formation................ 81

Andersson Land Formation ............... 83

Celsius Bjerg Group $\ldots \ldots \ldots \ldots \ldots \ldots \ldots \ldots \ldots . \quad 86$

Agda Dal Formation .................. 89

Elsa Dal Formation ..................... 96

Aina Dal Formation. .................. 97

Wimans Bjerg Formation .................. 99

Britta Dal Formation..................... 101

Stensiö Bjerg Formation .................. 102

Obrutschew Bjerg Formation............. 103

Harder Bjerg Formation................. 104

Acknowledgements ...................... 106

References............................ 106

Cover picture

Smith Woodward Bjerg overlooking Kejser Franz Joseph Fjord with approximately $950 \mathrm{~m}$ of continental Devonian sediments of the Kap Kolthoff and Kap Graah Groups. See also Fig. 32.

\section{Grønlands Geologiske Undersøgelse Ujarassiortut Kalaallit Nunaanni Misissuisoqarfiat Geological Survey of Greenland}

The Geological Survey of Greenland (GGU) is a research institute affiliated to the Mineral Resources Administration for Greenland (MRA) within the Danish Ministry of Energy. As with all other activities involving the non-living resources in Greenland, GGU's investigations are carried out within the framework of the policies decided jointly by the Greenland Home Rule Authority and the Danish State. 


\section{Dansk sammendrag}

Devone sedimentære bjergarter i Nordøstgrønland dækker et område på størrelse med Sjælland og andrager en kummulativ tykkelse på mere end $8 \mathrm{~km}$. Sedimenterne er aflejret i et kontinentalt, intramontant aflejringsbassin i perioden umiddelbart efter den kaledonske bjergkædedannelse. Omfattende sedimentologiske og strukturgeologiske undersøgelser i området (1986-88) har ført til en stærkt revideret litostratigrafi, som præsenteres i denne bulletin (Plate 1).

De devone aflejringer er inddelt i 4 litostratigrafiske grupper: Vilddal Gruppen (ældst), Kap Kolthoff Gruppen, Kap Graah Gruppen og Celsius Bjerg Gruppen (yngst). Alderen spænder fra øvre mellem Devon (Givetian) til øvre Devon (Famennian). Hver gruppe repræsenterer en overordnet bassin-palæogeografi, som adskiller sig fra de øvrige gruppers. Gruppegrænserne repræsenterer større tektoniske/klimatiske begivenheder, som tolkes foregået over et relativt kort tidsrum, og gruppegrænserne betragtes derfor som 'eventstratigrafiske' niveauer. Internt er grupperne inddelt $i$ et antal formationer, som repræsenterer aflejringssystemer, dvs. selvstændige geomorfologiske elementer $\mathrm{i}$ den overordnede palæogeografi. Formationerne kan skelnes fra hinanden på deres litologi, faciesassociationer og palæostrømretninger og er karterbare på en subregional skala. Der er ialt defineret 23 formationer inden for de 4 grupper, samt en yngre, selvstændig formation uden for grupperne. Enkelte formationer er inddelt i members af både sedimentologiske og kortlægningsmæssige årsager.

\section{Imaqarnersiuineq}

Tunup Avannaarsuani ujaqqat sedimentiusut Devonip nalaani pinngorsimasut nuna Sjællanditut isorartutigisoq qallersimavaat qaleriiaallu katillutik $8 \mathrm{~km}$ sinnerlugu issussuseqarlutik. Sedimentit nunatoqarsuup qaqqarsuaqarfiisa akornanni Tunumi Caledoniap qaqqarsuisa pinngoreersimatsiarnerisa kingorna kiviorarsimapput. Sedimentit tamaani sananeqaataasa qanorlu peqititersimanerisa sukumiisumik misissoreernerisa kingorna (1986-88) ujaqqat qanga pinngorsimanerat erseqqinnerusumik paasineqarsimavoq, tamannalu nalunaarusiami uvani allaaserineqarpoq.

Devonip nalaani kiviorarsimasut ujaqqanut qaleriiaanut sisamanut immikkoortinneqarsimapput: Vilddal Gruppen (pisoqaanerit), Kap Kolthoff Gruppen, Kap Graah Gruppen aamma Celsius Bjerg Gruppen (pisoqaannginnerit). Pisoqaassusaat Devonimi immikkoortut qiterliit naalernerannit (Givetian) qalliit (Famennian) tikillugit pisoqaassuseqarpoq. Immikkoortut ta- marmik taamanersuaq imartorumarngit pissusaannik ersissitsipput immikkoortinneqarsinnaasunik. Immikkoortullu akorngi tassaapput ukiut amerlavallaanngitsut nunap silaannaallu pissusiisa allanngornerinik oqaluttuartut. Immikkoortut imminni suli ujaqqanut ataatsimoortunut (formationinut) immikkoorteqqinneqarsimapput, taakkuuppullu nunatoqarsuarmi kiviorarfiusimasunik oqaluttuartut. Ujaqqat ataatsimoortut sunik sananeqaateqarnerat, sumi kiviorarsimanerat kiviorarsimasullu sumut sammiveqarnerat tunngavigalugit immmikkoortinneqarsinnaapput nunallu assinganut titartarneqarsinnaallutik. Immikkoortut sisamat iluanni ujaqqat ataatsimoortut 23-t ilisarineqarsinnaapput, taakkulu saniatigut ujaqqat ataatsimoortut pisoqaannginnerusullu ilisarineqarsinnaallutik. Ujaqqat ataatsimoortut ataasiakkat suli immikkoorteqqinneqarsimapput ujaqqat sedimentinik nunallu assiliornermi periaatsit peqqutigalugit. 


\section{Introduction}

Several kilometres of clastic sediments were deposited in an intramontane basin in North-East Greenland during the Middle and Late Devonian (Friend et al., 1983). The succession in North-East Greenland has been studied by the present authors and a new lithostratigraphy is presented (Plate 1).

The basin was initiated in the Middle Devonian due to an E-W extensional collapse of an overthickened Caledonian welt associated with $\mathrm{N}-\mathrm{S}$ sinistral strike-slip deformation (Larsen \& Bengaard, 1991). During the basin evolution more than $8 \mathrm{~km}$ of continental clastic deposits accumulated in various depositional facies and environments (e.g. Friend et al., 1983; Olsen, 1993). The Devonian sedimentary rocks rest unconformably on Ordovician carbonates and older rocks (Larsen, 1990a). During deposition, the Devonian basin fill underwent a series of deformations (Hudson Land and Ymer $\varnothing$ phases of Bütler, 1935), which seem to have controlled the sedimentary facies distribution and drainage pattern (Larsen 1990b,c,d; Larsen \& Olsen, 1991; Olsen, 1993; Olsen \& Larsen, 1993). Along the eastern basin margin Devonian sedimentary rocks are generally in fault contact with Upper Palaeozoic and Mesozoic deposits. A small outlier of Devonian rocks is present in Wegener Halvø and Canning Land approximately $100 \mathrm{~km}$ to the SSE indicating a much larger palaeogeographical extension of the Devonian basin than that seen today (Fig. 1). Seismic studies from Jameson Land further south also indicate the presence of deeply buried Devonian sediments in that area (Larsen et al., 1989).

Field work in North-East Greenland supported by helicopter was carried out in the summers of 1986-1988 (Marcussen et al., 1987, 1988; Larsen et al., 1989). In 1988 ground transport was additionally aided by rubber dinghy in some of the fjords. The work was carried out as an integrated structural and sedimentological study based on detailed and general facies logging plus mapping of facies associations and lithostratigraphic units using vertical aerial photographs (1: 50000 and 1:150 000) as field sheets. The field results were combined with computer assisted stereoscopic studies of vertical aerial photographs $(1: 150000)$. The instrument applied in this study is a Kern PG2 stereo plotter with $x$, $y, z$ encoders connected to a Hewlett Packard 1000 computer at the Geological Survey of Greenland.

The present lithostratigraphy is in accordance with the lithostratigraphic code of NACSN (1983). Sedimentological studies concerning lithology, sedimentary structures, palaeocurrents, depositional environments and section matching have been carried out mainly by Henrik Olsen. Aspects of the sedimentology have been presented in Olsen (1990, in press), Bendix-Almgreen et al. (1990), Larsen \& Olsen (1991), Kelly \& Olsen (1993) and Olsen \& Larsen (1993). A detailed sedimentary basin analysis is provided in Olsen (1993). The structural setting of the basin and the distribution, thickness and general geometry of lithostratigraphic units have been studied mainly by Poul-Henrik Larsen, and reported in Larsen (1990a,b,c,d), Larsen \& Bengaard (1991), Larsen \& Olsen (1991) and Olsen \& Larsen (1993).

A genetic stratigraphic approach has been used in the definition of lithostratigraphic units (Olsen, 1993). The subdivision into formations is accordingly based on depositional system analysis (Miall, 1984), i.e. individual formations generally represent entire depositional systems, clearly identifiable on the basis of lithology, facies associations and palaeocurrents. The formations are always mappable on a subregional scale. Members have been established where appropriate. They represent subsystems within larger depositional systems (e.g. braidplain segments) and are mappable on a local to subregional scale. The definition of lithostratigraphic groups is based on event stratigraphy. The group boundaries represent major events in the basin evolution reflected in basin-wide change of the palaeogeography supposedly occurring over a short geologic time interval, although detailed biostratigraphic control or absolute dating are not available. Further details on the depositional system analysis and event stratigraphy are provided in Olsen (1993) and Olsen \& Larsen (1993).

The lithostratigraphic units established in the central area have been mapped within a larger part of the basin (Fig. 1) (Larsen, 1991a). The areas around Kap Franklin and around Nordhoek Bjerg and Salèvebjerg have only briefly been visited by the present authors. Based on previous work by Alexander-Marrack \& Friend (1976) and Friend et al. (1983) the present lithostratigraphy is extended to include the Kap Franklin area, whilst the areas around Nordhoek Bjerg and Salèvebjerg are excluded. The Devonian rocks in Wegener Halvø and Canning Land in northern Jameson Land have likewise not been visited by the present authors and the existing lithostratigraphy by Alexander-Marrack \& Friend (1976) and Friend et al. (1983) for this area is suggested maintained (see the following sections).

Following a general review of previous work in the study area, the succession of new, revised and redefined 
units is discussed in ascending order in accordance with the proposed stratigraphic scheme (Plate 1).

A large number of detailed facies logs and generalized facies association logs are presented in this paper for documentation of the lithostratigraphy. A legend is provided in Plate 2.
At various levels in the Devonian sedimentary succession, extrusives and intrusives of both acid and basic magmatic rocks appear. These rocks are not incorporated in the present lithostratigraphy. For further descriptions of these rocks, the reader is referred to Haller (1971) and references herein.

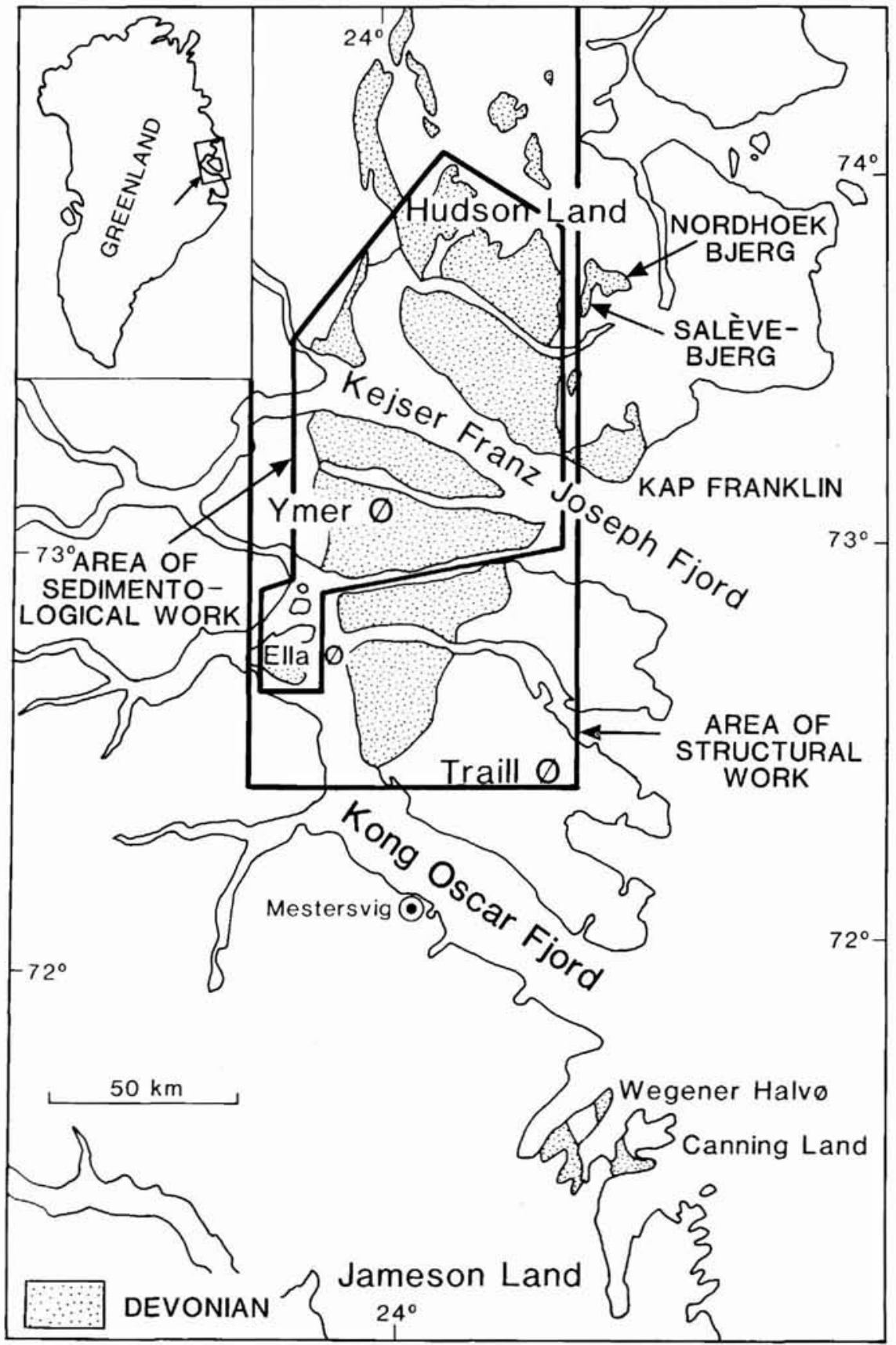

Fig. 1. Map showing the extent of the Devonian outcrops in East Greenland. Sedimentological and structural study areas forming the basis of the present lithostratigraphy are indicated. 


\section{Review of research and stratigraphy of the Devonian in North-East Greenland}

During the search in 1899 along the North-East Greenland coast for possible survivors of the ill-fated 'Andrée balloon expedition', a Swedish expedition under the leadership of A. G. Nathorst had the opportunity to explore Kejser Franz Joseph Fjord and to make some important new geological observations.

Fish remains found in sandstone at Kap Graah were determined by Woodward (1900) to be Late Devonian in age. These findings led Nathorst (1901) to realize the existence of Devonian rocks in North-East Greenland, and he became the first to recognize the Palaeozoic age of the East Greenland fold belt from the angular unconformity in Narhvalsund between unfolded Devonian conglomerates and older folded presumed 'Silurian' rocks (Fig. 2).

About thirty years later in the late 1920s both Norwegian and Danish expeditions commenced an intense stratigraphic and palaeontologic investigation of the 'Old Red Sandstones' in North-East Greenland.

Orvin $(1930,1931)$, the leader of a Norwegian expedition in 1929, found some rew Devonian fossil localities. He tried to group the strata according to the colouring of the beds in an attempt to establish a lithostratigraphy of the Devonian sedimentary sequence (Fig. 3). Unfortunately, since the colour of the series changed in both vertical and horizontal directions (a problem which also later stratigraphers had to face) he was not able to correlate his units regionally. In addition the fjord valleys represented broad areas where the beds could not be followed and he therefore failed to correlate the fossil horizons with certainty. However, new fossil fish material was collected from Celsius Bjerg and Kap Graah and described by Heintz $(1930,1932)$.

Lauge Koch was the leader of the Danish expeditions to North-East Greenland in 1926 and 1927 (Koch, $1929 \mathrm{a}, \mathrm{b})$ and several expeditions in the following years. Kulling $(1930,1931)$, who was a member of Koch's expedition in 1929 , studied the unconformity at the base of the Devonian on Ymer $\emptyset$, its relief and its conglomeratic cover. He measured several stratigraphic sections, and subdivided the sediments into a preliminary lithostratigraphy (Fig. 3). On Celsius Bjerg on the eastern tip of Ymer $\emptyset$ he succeeded in finding remains of a tetrapod, which later became known as Ichthyostegalia. This discovery was considered as one of the great events in vertebrate palaeontology and all of a sudden made the Devonian of North-East Greenland known all over the world. The animals are the earliest tetrapods and the most primitive land vertebrates known being closest to bridge the gap between fish and tetrapods.

Although the first findings were made by Kulling in 1929, it was not until Säve-Söderbergh (1932b) had described seven incomplete skulls, which he collected himself as a member of Lauge Koch's expedition in 1931 at Celsius Bjerg that the order Ichthyostegalia became known and defined.

On a subsequent expedition led by Lauge Koch large fossil collections were obtained from both Celsius Bjerg and Gauss Halvø including representatives of all the principal groups of lower vertebrates. The large slabs of rocks containing the fossil remains were transported from the find localities to the shores of the fjords by the aid of Icelandic ponies; a complicated task compared to modern day helicopter-assisted fieldwork.

The fossil assemblages were prepared and studied by Swedish palaeontologists at the Naturhistoriska Riksmuséet in Stockholm, leading to a comprehensive list of publications of e.g. E. Stensiö, E. Jarvik, G. SäveSöderbergh and A. E. V. Johansson (see reference list for bibliography; see also Bendix-Almgreen (1976) for a summary of the Devonian palaeovertebrate fauna in North-East Greenland).

Based on the fish fauna Säve-Söderbergh (1932a, $1933,1934)$ was the first to succeed in dividing the Devonian succession into several stratigraphic series and thus to establish the first biostratigraphy of the

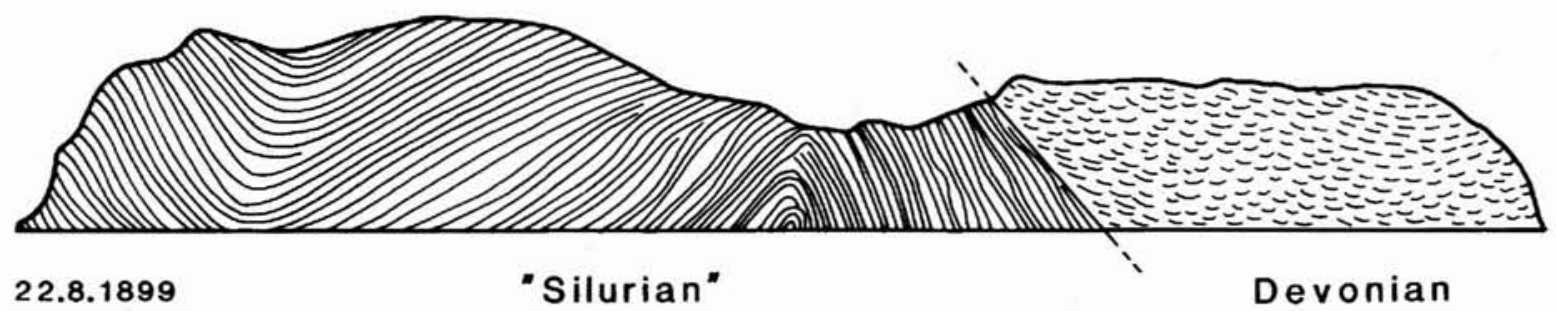

Fig. 2. A. G. Nathorst's geological profile showing the south cliff of the island Ella $\emptyset$ facing Narhvalsund (after Nathorst, 1901, p. 293). 


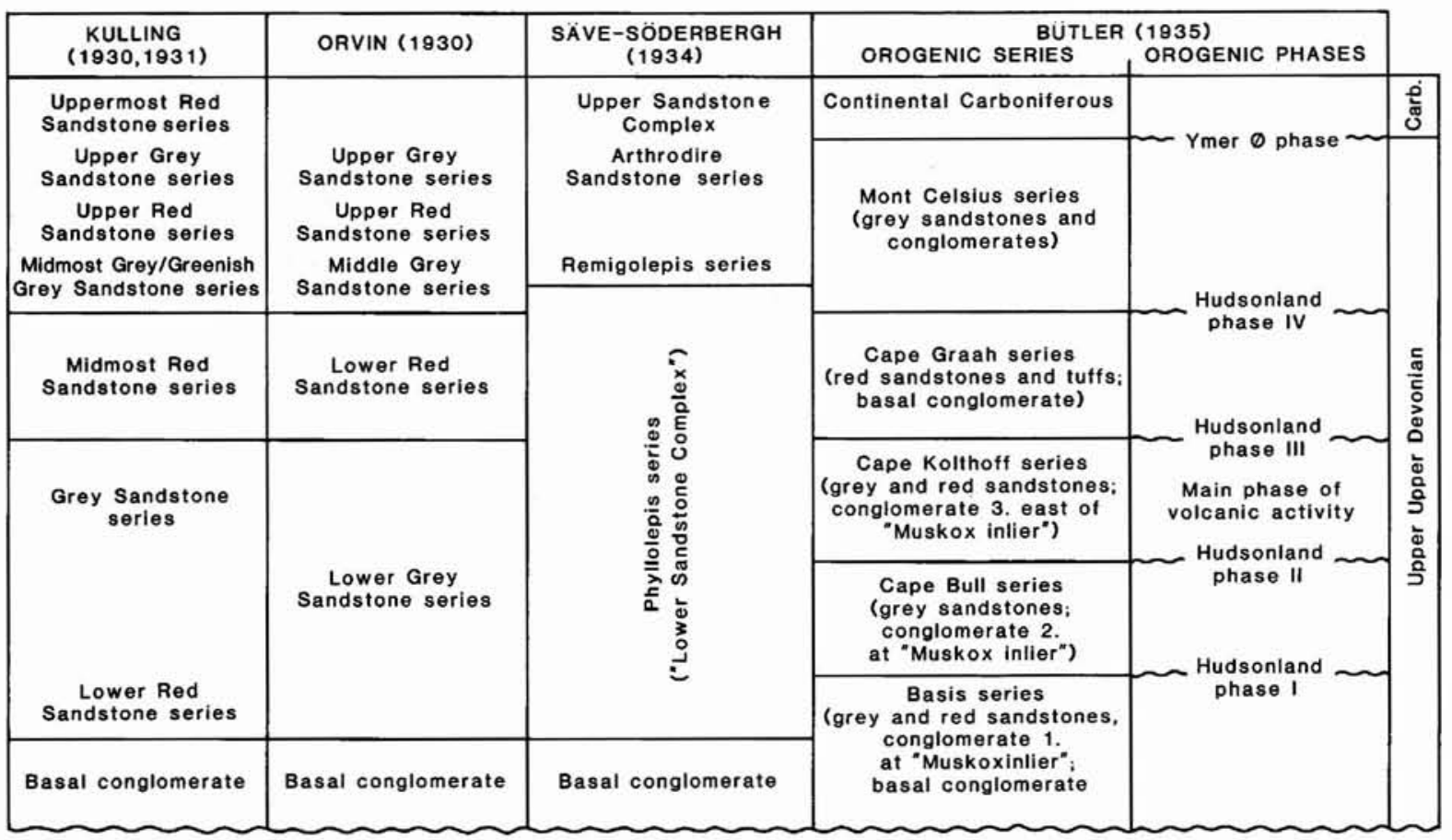

Fig. 3. Early attempts at stratigraphic subdivision of the Devonian sediments. The scheme is modified from the compilations of Bütler (1935) and Maync (1949).

North-East Greenland Devonian deposits (Fig. 3). He had the difficulty, though, that only the uppermost series was rich in fossils and that these were confined to rather small areas. The lower series was far thicker and had a more regional distribution, but they did not yield fossil material usable to subdivide them stratigraphically. Therefore the lower series was consigned in the Devonian Basal conglomerate, whose age within the Devonian was left open, and an Upper Devonian Phyllolepis series (also termed 'Lower Sandstone Complex') which was correlated with the youngest beds in other Old Red Sandstone areas in Europe. It was suggested that the highest series (Remigolepis series and Arthro. dire sandstone) were younger than all the Old Red sandstone formations in other areas known at that time.

A vertebrate palaeontological expedition in 1987 to Gauss Halvø and eastern Ymer $\emptyset$ (Bendix-Almgreen $e t$ al., 1988$)$ is the most recent palaeontological activity in the Devonian of North-East Greenland. Work is still in progress but initial results have already been presented (Clack, 1988, 1989; Bendix-Almgreen et al., 1988, 1990).

From 1933 to 1957 the Swiss geologist H. Bütler carried out the major pioneering lithostratigraphical and structural work on the Devonian areas. As a member of many of Koch's expeditions he spent 12 summers and one winter in North-East Greenland describing the sedimentary successions, the local occurrences of strongly angular unconformities within the Devonian sequences, and the existence of contemporaneous volcanic and plutonic igneous bodies. His detailed work has been reported in a long series of publications (see reference list) and summarized by Haller (1971). Bütler viewed the Devonian succession as an orogenic formation laid down in a N-S trending depression in the interior of the Caledonian foldbelt being influenced by important movements in Middle and Late Devonian. He emphasized the similarity of the Devonian succession to certain characteristics of the molasses in the Alps.

Bütler (1935) established a Devonian lithostratigraphy based on angular unconformities in the Hudson Land - Moskusoksefjord area and divided the succession into five 'Orogene Serien' (Fig. 3) which he tried to correlate to the biostratigraphy of Säve-Söderbergh (1934). Later Bütler (1954) incorporated the Kap Franklin area in his work, and through the years he gradually refined his general stratigraphy finally summarized by Bütler (1959, 1961; Fig. 4).

The biostratigraphy was summarized by Jarvik (1961) mixing previous biostratigraphic divisions with some of Bütler's orogenic series, but it was the allostratigraphic subdivisions of Bütler which formed the basis of the Devonian part of the geological map of North-East Greenland produced by Koch \& Haller (1971; Fig. 4). 


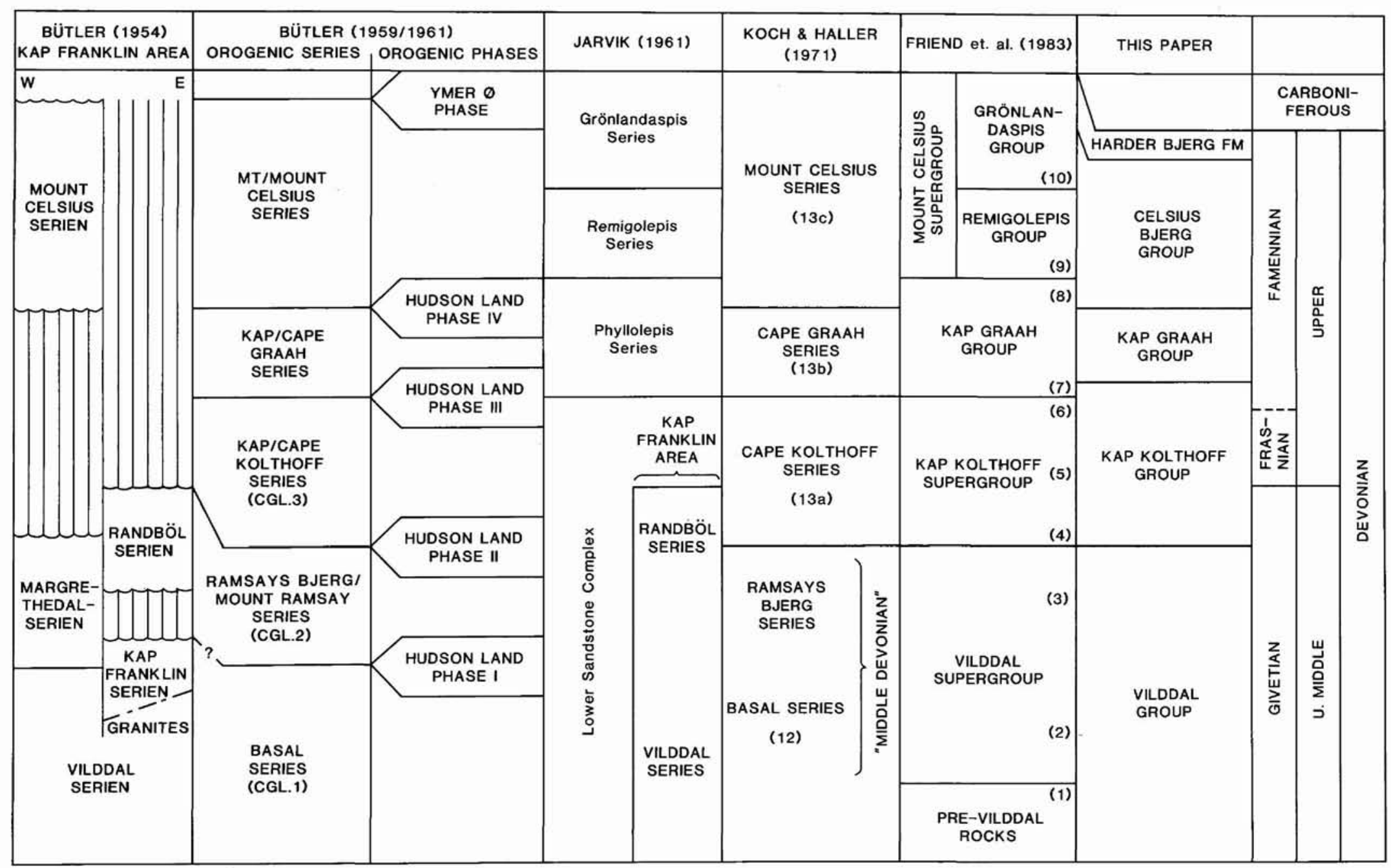

Fig. 4. Stratigraphic schemes from 1954 to 1983 covering the Devonian sediments, with correlation to the main lithostratigraphical subdivision proposed in the present paper. The studies of Alexander-Marrack \& Friend (1976), Nicholson \& Friend (1976) and Yeats \& Friend (1978) are represented by the formalized lithostratigraphy of Friend $e t$ al. (1983). 


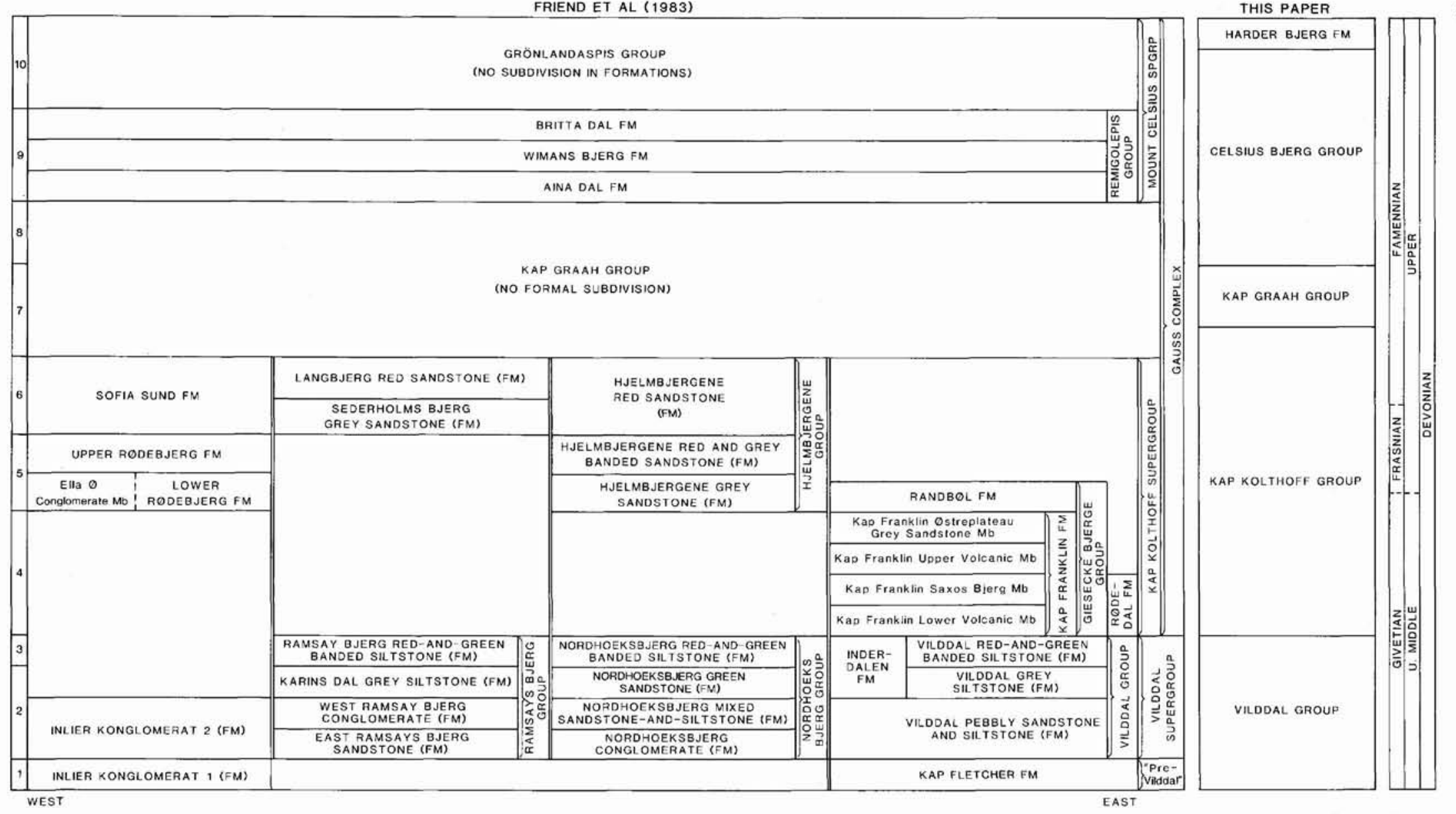

Fig. 5. Scheme of the previous detailed stratigraphical subdivision of the Devonian deposits by Friend et al. (1983, based on Alexander-Marrack \& Friend, 1976; Nicholson \& Friend, 1976; Yeats \& Friend, 1978) and correlated with the new lithostratigraphic subdivision proposed in the present paper. 
This rather confusing mixture of bio- and lithostratigraphy was the starting point for three English expeditions led by P. F. Friend, Cambridge in the summers of 1968-1970. From a sedimentological basis using computer techniques in data compilation the Devonian succession was studied in great detail and documented in a series of comprehensive papers (Friend et al. 1976a, b, 1983; Alexander-Marrack \& Friend, 1976; Yeats \& Friend, 1978; Nicholson \& Friend, 1976). Aided by the growing understanding of sedimentary geology in those years the Cambridge group succeeded in adding many new aspects to the development of the Devonian basin. The fluviatile nature of most of the sediments was documented and great insight into the facies and drainage patterns was gained.

Based on the stratigraphic division and names used by Bütler $(1935,1954,1959,1961)$ the Cambridge group erected a series of lithostratigraphic units (Fig. 5) which were formalized, however inadequately in Friend $\mathrm{et} \mathrm{al}$. (1983, p. 10-15). Much new fossil vertebrate material was collected associated with a palynologica! investigation leading to a Givetian (Middle Devonian) age for the basal conglomerate on Ella $\varnothing$ (Allen, 1972).

From the sedimentological investigations Friend et al. (1983) suggested that the tectonic situation of the Devonian basin was dominated by a series of four more-orless northerly trending fracture zones. They proposed that these fractures were probably largely generated by wrench stresses and periodically showed some components of strike-slip. Their surface effects were thought to include both vertical and horizontal components of motion.

The most recent geological activity in the Devonian of North-East Greenland was under the auspices of three expeditions mounted by the Geological Survey of Greenland during the summers of 1986, 1987 and 1988 (Marcussen et al. 1987, 1988; Larsen et al. 1989; Larsen \& Olsen, 1991). Sedimentological and structural analyses were carried out by the authors of the present paper in order to get an up to date view of the various sedimentological aspects as well as an overall geometrical understanding of the structural setting and evolution of the basin. Work is still in progress on the data collected, but the investigations have already contributed new knowledge of both the structural and sedimentary basin evolution as previously mentioned in the introduction.

To summarize, the geological research of the Devonian successions in North-East Greenland was intensified after 1929 following the fossil discoveries on Celsius Bjerg of the earliest land-living vertebrates. The geological results of the expeditions from the first 60 years of the century, mainly mounted by Lauge Koch, were admirably summarized by Haller (1971). The work by the Cambridge expeditions led by Peter F. Friend (1968-70) was summarized in Friend et al. (1983) and formed the starting point for the present work.

\section{Vilddal Group}

History and general remarks. Sediments of this group were studied in detail in the main part of the outcrop area (Fig. 6). However, in northern Hudson Land, eastern Moskusoksefjord and the Kap Franklin area (Fig. 1) the sediments were only briefly investigated. Bütler $(1954,1959,1961)$ erected the 'Vilddal Series (Vilddal Serien)' (Fig. 4) for a sequence of grey-green sandstones and conglomerates succeeded by a sequence of alternating green and red sandstones. The Vilddal Series in the sense of Bütler $(1954,1959)$ was only defined for the Kap Franklin area. Later Alexander-Marrack \& Friend (1976) renamed the sediments as the 'Vilddal Group'. The 'Vilddal Group' sensu Alexander-Marrack \& Friend (1976) were included by the same authors in their 'Vilddal Supergroup' (Figs 4, 5). The supergroup also comprised the 'Ramsays Bjerg Group' in the eastern Moskusoksefjord area and the 'Nordhoeks Bjerg Group' in Hudson Land. Also included in the supergroup was the 'Nathorst Fjord Group' in the Canning
Land and Wegener Halvø area (Alexander-Marrack \& Friend, 1976). The latter area is not included in the present study and the 'Nathorst Fjord Group' is suggested maintained as a separate group until new investigations document its relation to the Vilddal Group. The remaining part of 'Vilddal Supergroup' is suggested reduced to group status and the constituent groups abandoned, as they only served as geographic subdivisions of the unit and are inconvenient both from mapping and sedimentological points of,view.

The group encompasses the 'Ella $\varnothing$ Conglomerate Member' and parts of the 'Lower Rødebjerg Formation' and 'Upper Rødebjerg Formation' (Fig. 5) of Yeats \& Friend (1978). Also included in the group are the 'Ramsays Bjerg Serie', the 'Basis (Basal) Serie' and the 'Konglomerat 1' and 'Konglomerat 2' at the 'Moskusoksefjord Inlier' in the western Moskusoksefjord area (Bütler, 1959; Fig. 4).

On the map by Koch \& Haller (1971) the group is 
represented as part of the 'Middle Devonian' deposits (Fig. 4).

Name. After the valley Vilddalen $10 \mathrm{~km}$ north of Kap Franklin (Figs 1, 7).
Type area. Hudson Land (Fig. 6).

Thickness. The group reaches a maximum preserved thickness of about $2500 \mathrm{~m}$ in the Ankerbjergselv area in Hudson Land. Along the western margin of the basin

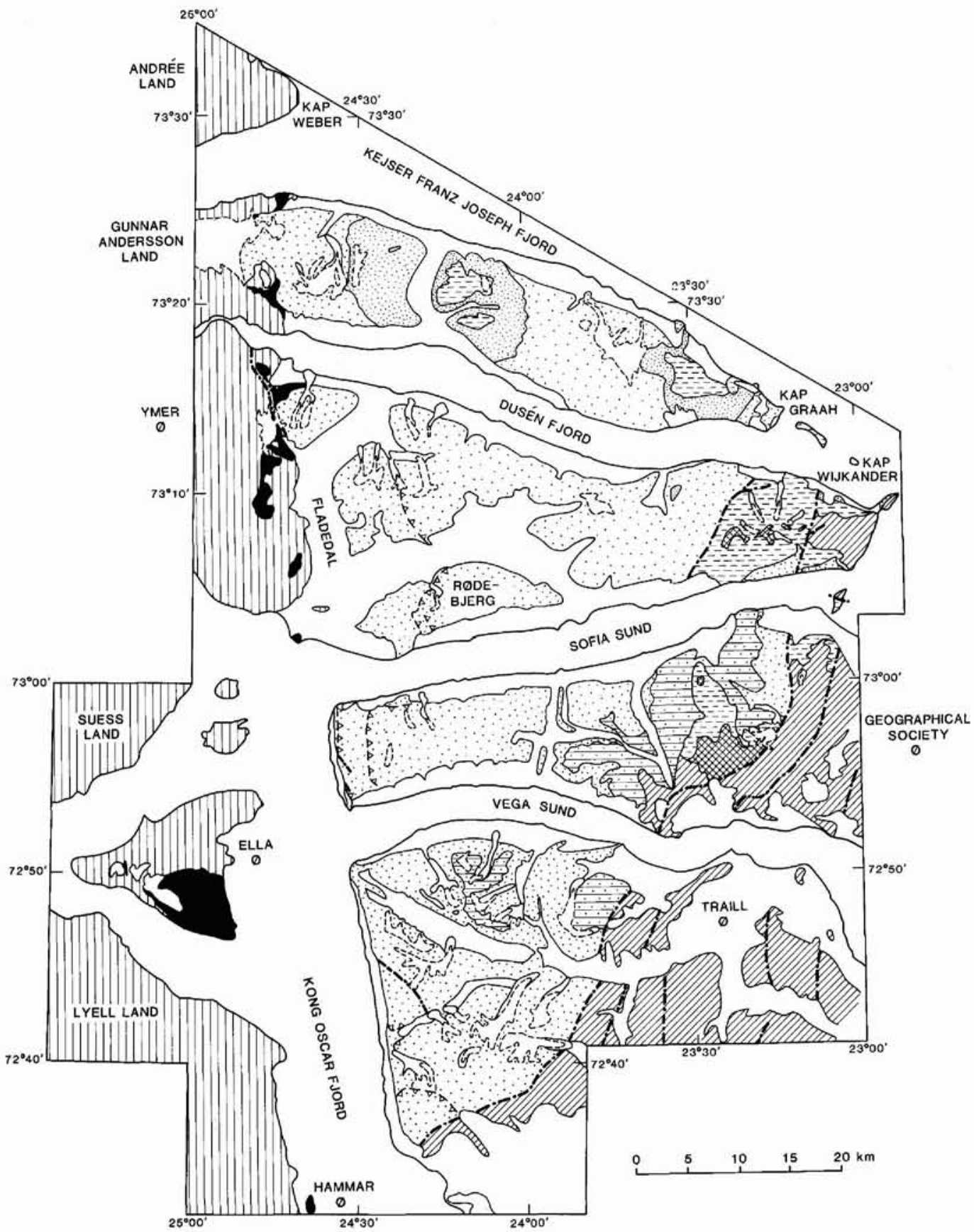

Fig. 6. Geological map of the Devonian basin based on Larsen (1990a), showing the areal distribution of lithostratigraphic groups proposed in the present paper. Areas where detailed investigations have been carried out by the present authors are shown in Fig. 1. 
DISTRIBUTION OF LITHOSTRATIGRAPHIC GROUPS

DEVONIAN

HARDER BJERG FM

E=--A CELSIUS BJERG GROUP

UNDIFFERENTIATED CELSIUS BJERG GROUP AND TOPMOST KAP KOLTHOFF GROUP

KAP GRAAH GROUP

$\because \because$ KAP KOLTHOFF GROUP

VILODAL GROUP

ए QUATERNARY

(i) GLACIERS WITH MORAINES

POST-DEVONIAN ROCKS

[17] PRE-DEVONIAN ROCKS

Fig. 6. cont.

smaller thicknesses are preserved $(300-1300 \mathrm{~m})$. However, the original thickness of the unit is difficult to estimate as the upper boundary is normally an unconformity and/or the lower boundary is unexposed.

Dominant lithology. The group forms a major fining upward succession (Fig. 12). The lower part of the

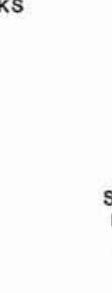
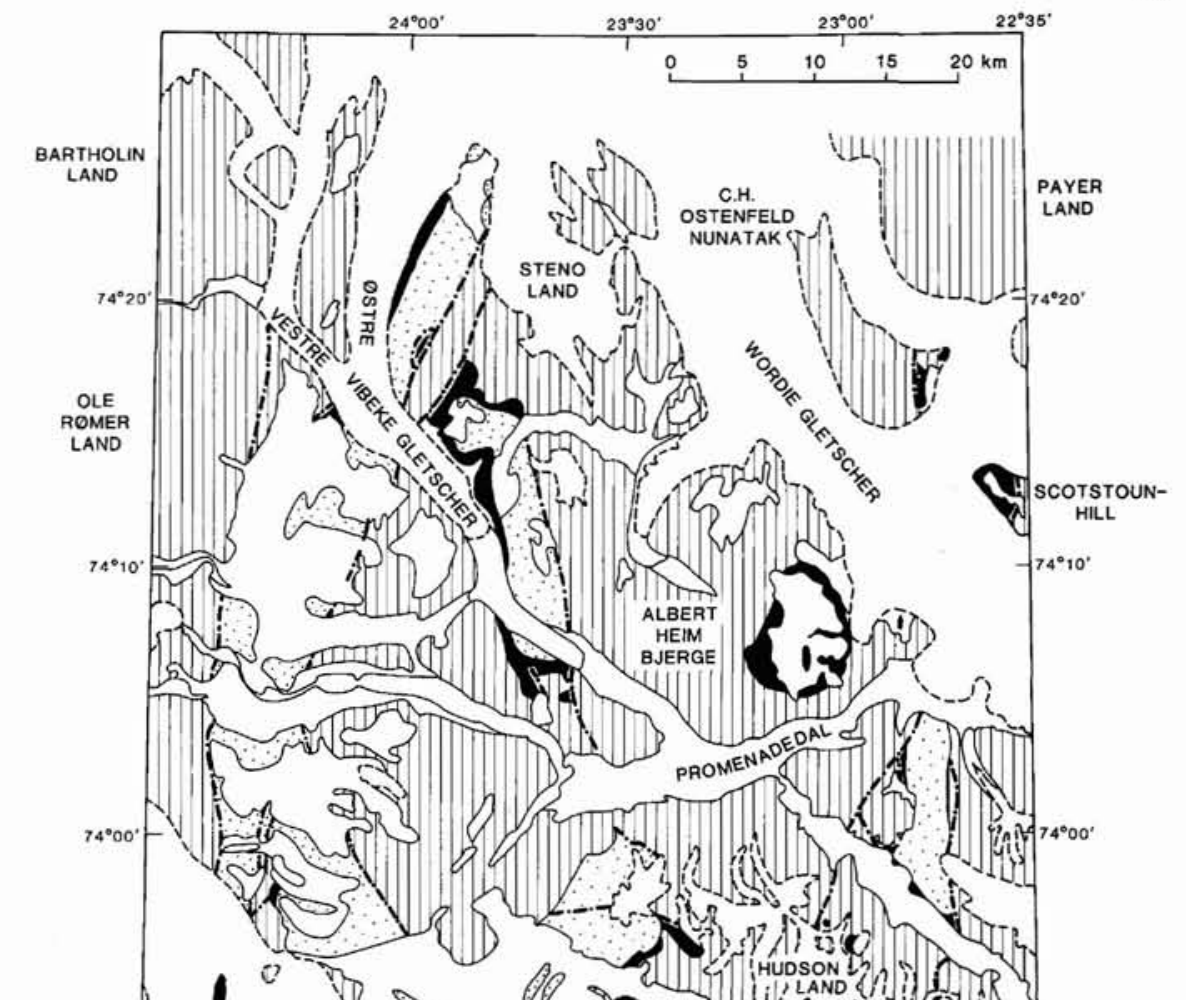


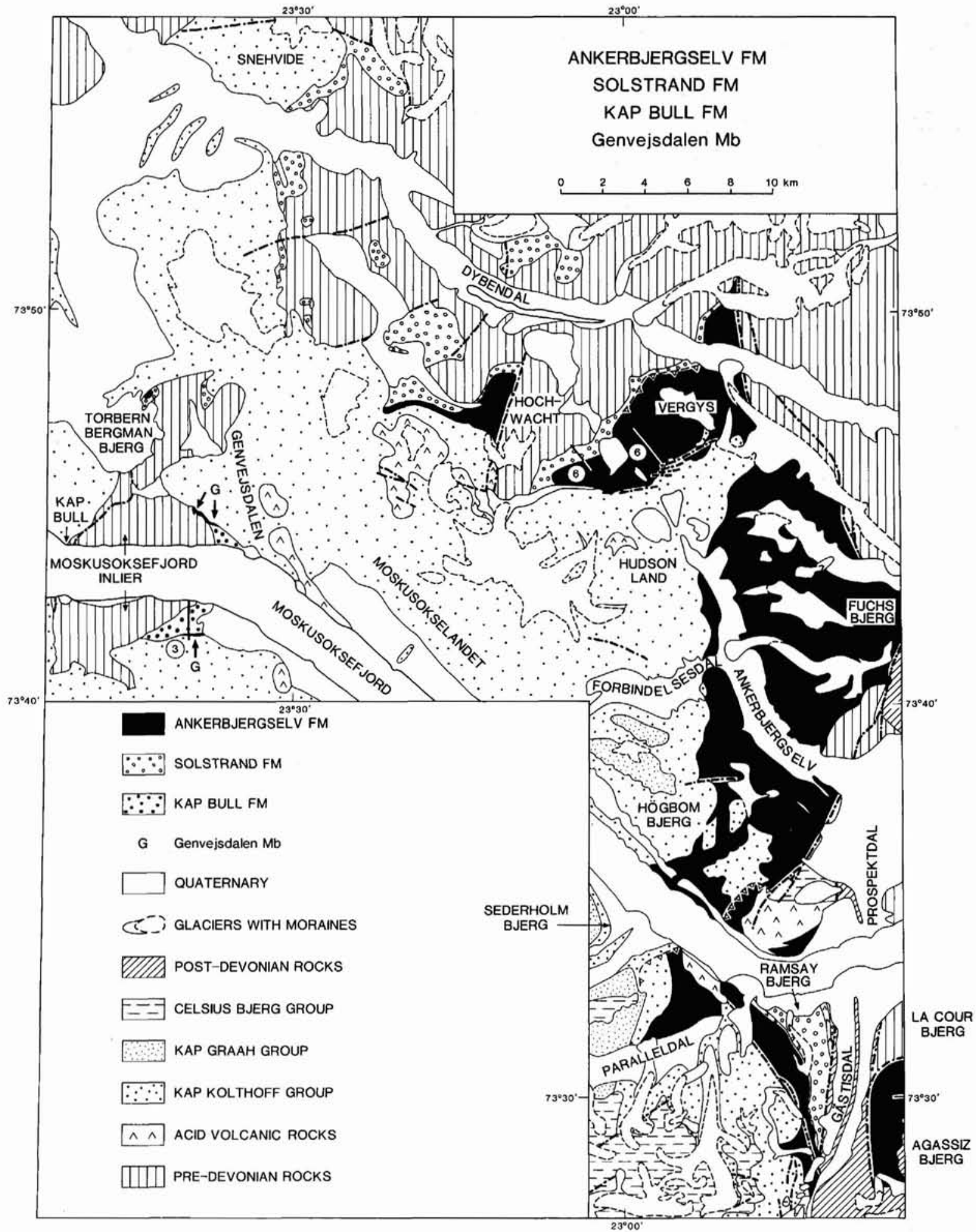

Fig. 8. Geological map of Hudson Land and the Moskusoksefjord area showing the distribution of the Ankerbjergselv, Solstrand and Kap Bull Formations including the Genvejsdalen Member (Vilddal Group). Locations of type section 3 of the Genvejsdalen Member and type section 6 of the Solstrand Formation are indicated. 


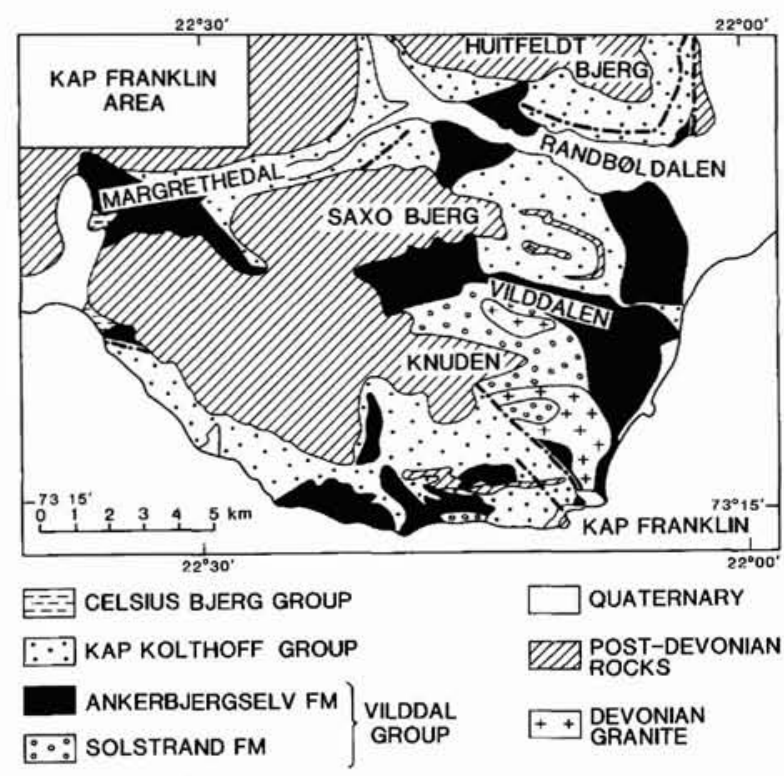

Fig. 7. Geological map of the Kap Franklin area based on Alexander-Marrack \& Friend $(1976$, figs 8, 9) showing the distribution of the new lithostratigraphic units proposed in the present paper. The area was only briefly visited during reconnaissance by the present authors.

group comprises conglomerates, mainly composed of pre-Devonian carbonate clasts. In the eastern part of the outcrop area, in the Kap Franklin area these basal sediments are finer-grained, composed of pebbly sandstone with interbedded siltstone. The conglomerates and pebbly sandstones are generally grey, weathering red. The upper part of the group is composed of alternating red and green sandstones and siltstones and subordinate grey siltstones, directly overlying the conglomerates. The proportion of siltstone increases to the east.

Depositional environments and palaeocurrents. The lower part of the Vilddal Group represents gravelly braided rivers and subordinate alluvial fan deposition (Olsen, 1993). The red and green coloured upper part of the group was mainly deposited by meandering and braided rivers, ephemeral streams and associated floodplains (Olsen, 1993).

Palaeocurrents are generally towards the east and the grain-size generally decreases in the same direction (Alexander-Marrack \& Friend, 1976; Olsen, 1993). Collectively this indicates a source area, and thus a basin margin, west of the outcrop area. Based on sedimentological information from the outcrop area there is no indication of a nearby eastern margin to the basin during deposition of the group (Alexander-Marrack \& Friend, 1976).

Boundaries. The lower boundary is exposed in Hudson Land where it is defined by the abrupt and unconformable change from crystalline rocks or sediments of Precambrian to Ordovician age, to conglomerates of the Vilddal Group (Figs 6, 8, 13). In the western part of the basin the group rests unconformably on Precambrian to early Ordovician sediments (Figs 9, 10, 11, 14). The base of the group is not exposed in the eastern outcrop area south of Moskusoksefjorden. To the west the southern limit of exposures is on Ella $\emptyset$ (Fig. 6) with small outliers on Hammar $\varnothing$, Aakerblom $\varnothing$ and in the Syltoppene area along Kong Oscar Fjord. The upper boundary is generally an angular or erosional unconformity and defined by an abrupt change from red and green sandstones and/or siltstones to green, grey or white sandstones and conglomerates or volcanics of the Kap Kolthoff Group (Figs 6, 12).

Distribution. In the study area the group is exposed in Steno Land, Ole Rømer Land, Hudson Land, Gauss

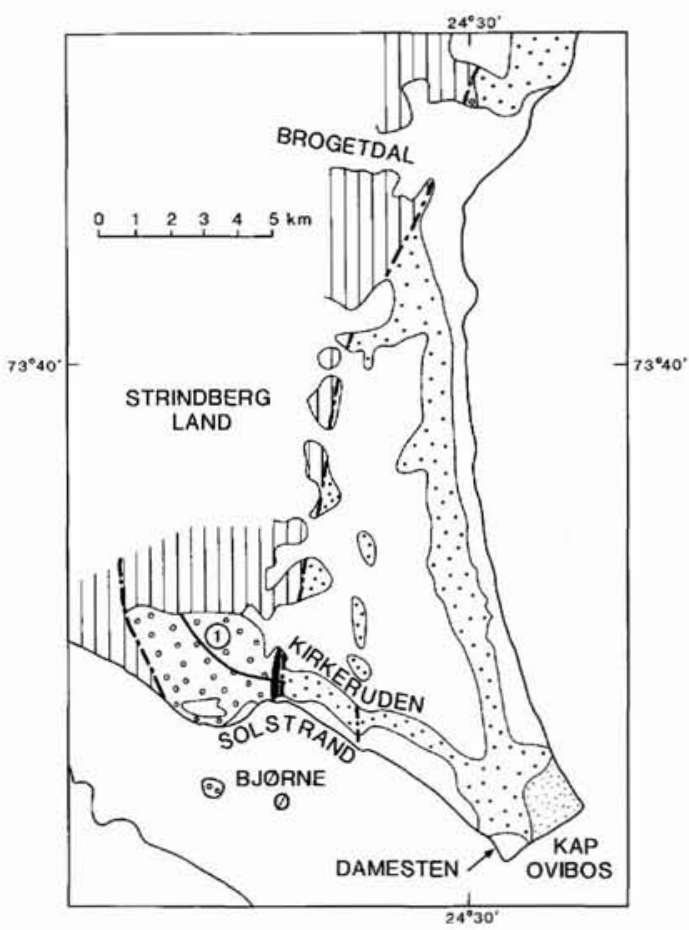

Fig. 9. Geological map of southeastern Strindberg Land showing the distribution of the Ankerbjergselv and Solstrand Formations (Vilddal Group). Location of section 1 is indicated. Legend corresponds to Fig. 8 . 
Halvø, southern Strindberg Land, western Ymer $\emptyset$, western Geographical Society $\emptyset$ and Ella $\varnothing$ (Fig. 6). Outliers only briefly examined by the authors occur on Hammar $\emptyset$, Aakerblom $\emptyset$ and in the Syltoppene area along Kong Oscar Fjord (see also Larsen, 1990a).

Geological age. Jarvik (1950) suggested a late Middle Devonian (Givetian) age on the basis of fossil fish from eastern Gauss Halvø. Spores and megaspores found on Ella $\emptyset$ also indicate a Givetian age of the group (Allen, 1972; Friend et al., 1983).

Subdivisions. The Vilddal Group is subdivided into three formations, the Solstrand Formation, the Kap Bull Formation and the overlying Ankerbjergselv Formation (Plate 1). These formations are described in the following.

\section{Solstrand Formation}

new formation

History. The formation includes the 'Nordhoeksbjerg Conglomerate' and overlying 'Nordhoeksbjerg (Mixed) Sandstone-and-siltstone Formation' and the 'Vilddal Pebbly Sandstone-and-siltstone Formation' defined by Alexander-Marrack \& Friend (1976) and Friend et al. (1983) (Fig. 5). It also encompasses the 'Ella $\emptyset$ Conglomerate Member' (Yeats \& Friend, 1978) and the conglomerates forming the basal part of the Devonian succession in Strindberg Land and Ymer $\emptyset$. These sediments were tentatively included in the 'Lower Rødebjerg Formation' and the 'Upper Rødebjerg Formation' by Yeats \& Friend (1978). The 'West Ramsays Bjerg

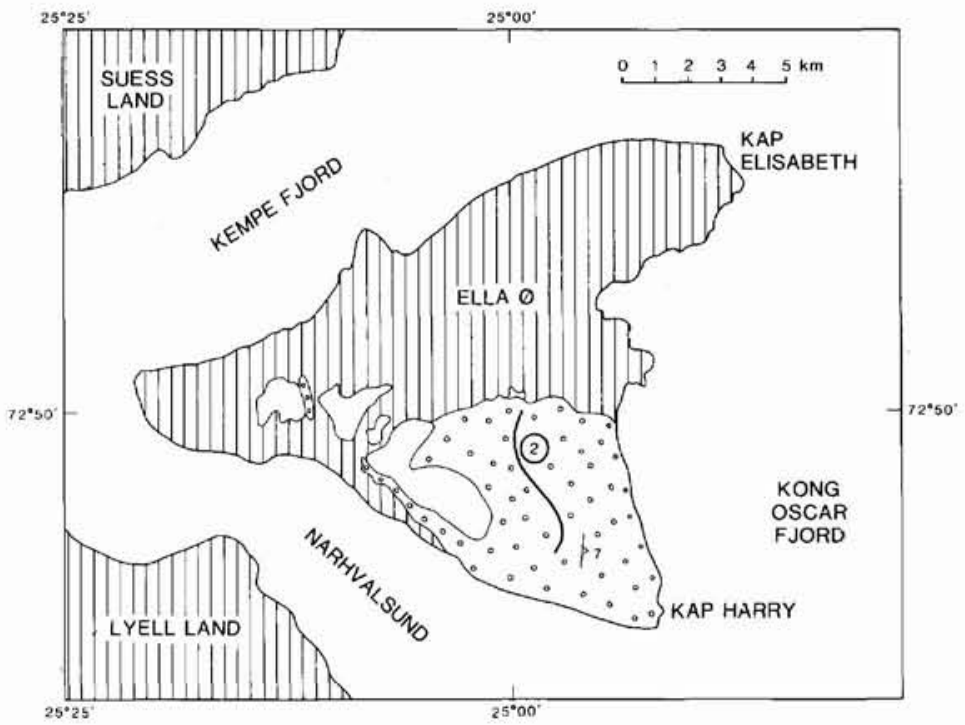

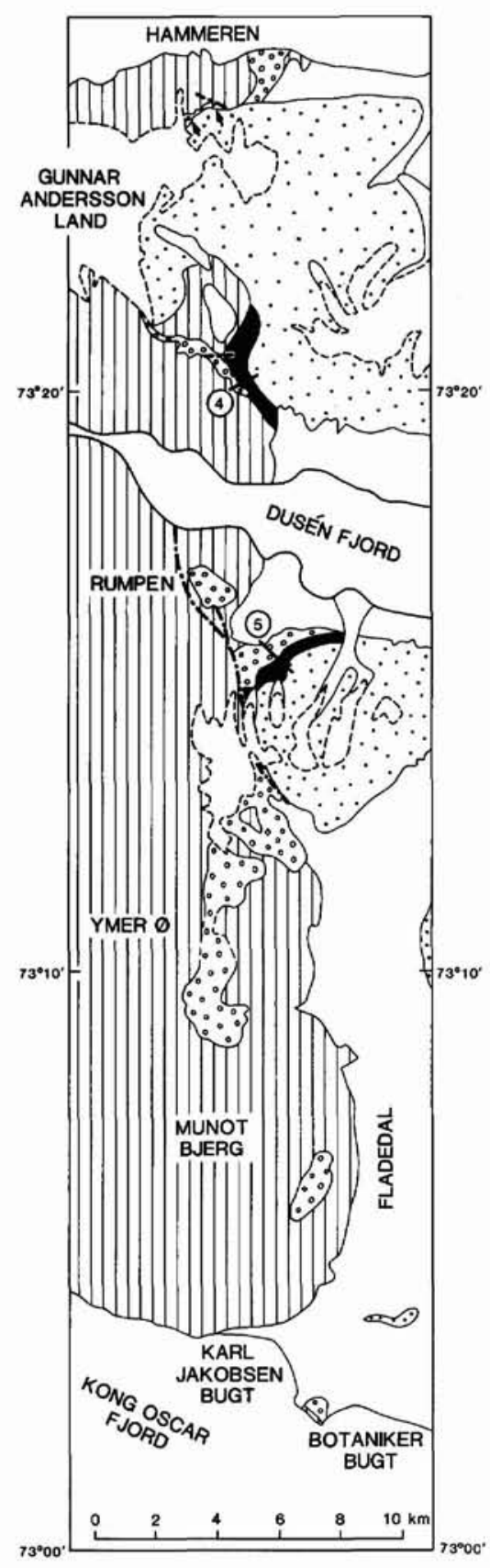

Fig. 10. Geological map of western Ymer $\varnothing$ showing the distribution of the Ankerbjergselv and Solstrand Formations (Vilddal Group). Locations of sections 4 and 5 are indicated. Legend corresponds to Fig. 8 .

Fig. 11. Geological map of Ella $\emptyset$ showing the distribution of the Solstrand Formation (Vilddal Group). Location of section 2 is indicated. Legend corresponds to Fig. 8. 


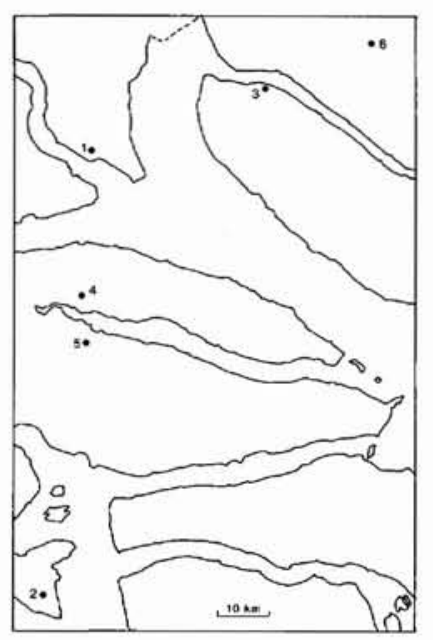

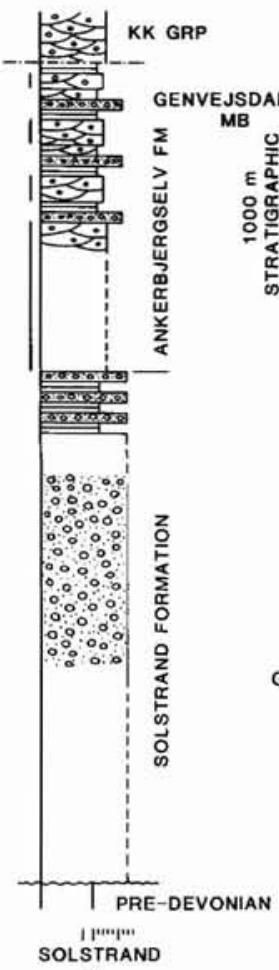

(1)

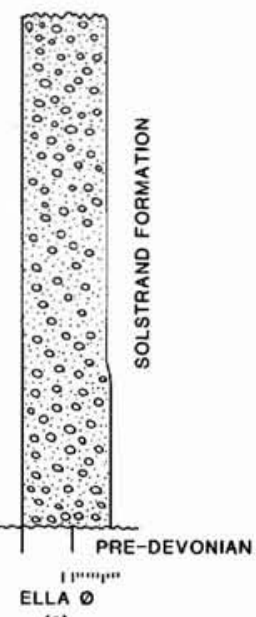

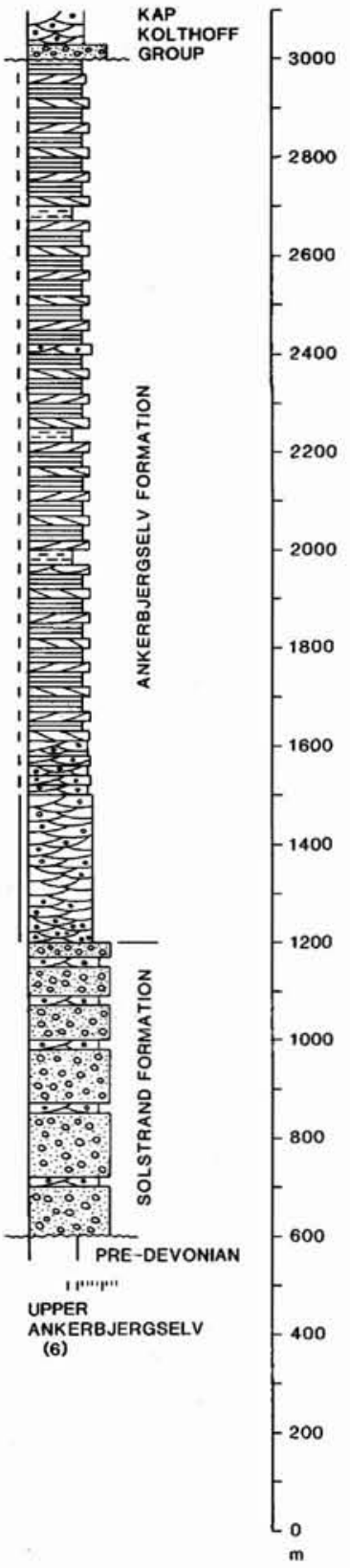

(2)

(5)
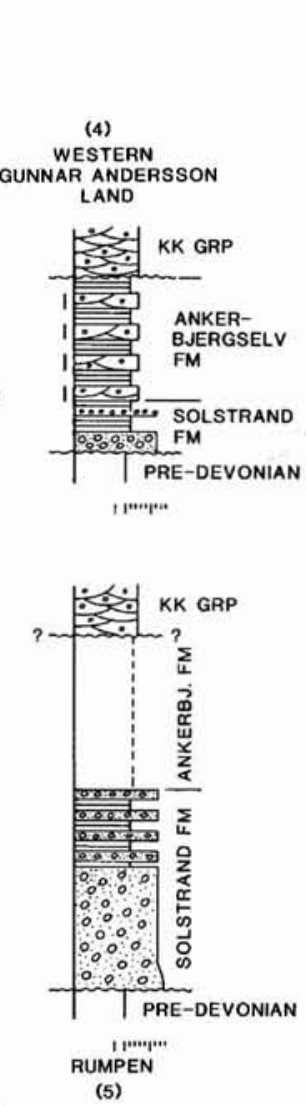

(3)

$m$

Fig. 12. Generalized sections in the Vilddal Group. For location see also Figs $8,9,10,11$. Section 6 is the type section of the Solstrand and Ankerbjergselv Formations. Section 3 is the type section of the Kap Bull Formation and Genvejsdalen Member. The thickness of Ankerbjergselv Formation in section 1 is from Yeats \& Friend (1978, p. 13). According to Bütler (1948, p. 114, 116) the $c .300 \mathrm{~m}$ thick green sandstone in the lower part of Ankerbjergselv Formation (Yeats \& Friend, 1978, p. 13), indicated by dashed line, is not present. Legend is provided in Plate 2. 
Fig. 13. Northwestern part of the Ankerbjergselv valley in Hudson Land. The mountain ridge to the northwest is the lower part of the type section (section 6 in Figs 8, 12) of the Solstrand Formation (SST) and Ankerbjergselv Formation (A) overlying the Precambrian Eleonore Bay Group (EBG). The Ankerbjergselv Formation is unconformably overlain by the Vergys Formation (V). The Sofia Sund Formation (SS) and the Watson Plateau Member (WP) top the sequence to the southeast. Length of the outcrop along the centre of the valley is $c .5$ $\mathrm{km}$.

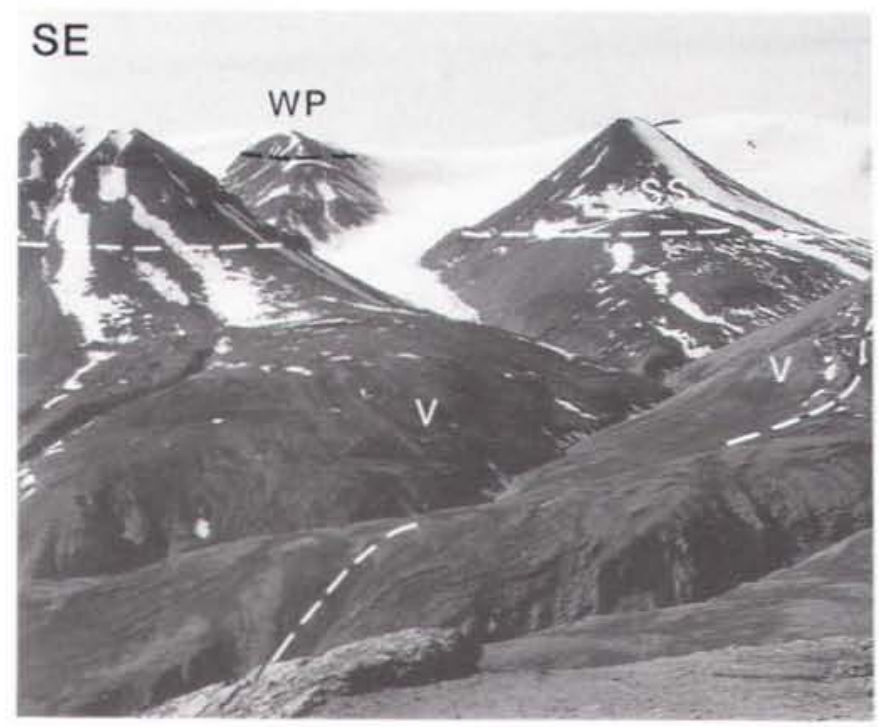

Conglomerate Formation' and 'East Ramsays Bjerg Sandstone Formation' by Alexander-Marrack \& Friend (1976) are also considered as part of the Solstrand Formation (Fig. 5). Included in the formation are conglomeratic parts of the 'Ramsays Bjerg Series', the 'Basis Series' and parts of the 'Vilddal Series' defined by Bütler (1935, 1954, 1959; Figs 3, 4). We suggest all these older names to be abandoned as they merely served as geographic subdivisions of one probably diachronous but genetical equivalent unit which can be treated as such.

On the map by Koch \& Haller (1971) the formation was included in the 'Middle Devonian' mapping unit (Fig. 4).

Name. After Solstrand on the south coast of Strindberg Land (Fig. 10).

Type and reference sections. The type section is located in upper Ankerbjergselv in Hudson Land (section 6 , Figs 8, 12, 13). The reference sections are Solstrand (section 1. Figs 9, 12, 14), Ella $\emptyset$ (section 2, Figs 11,

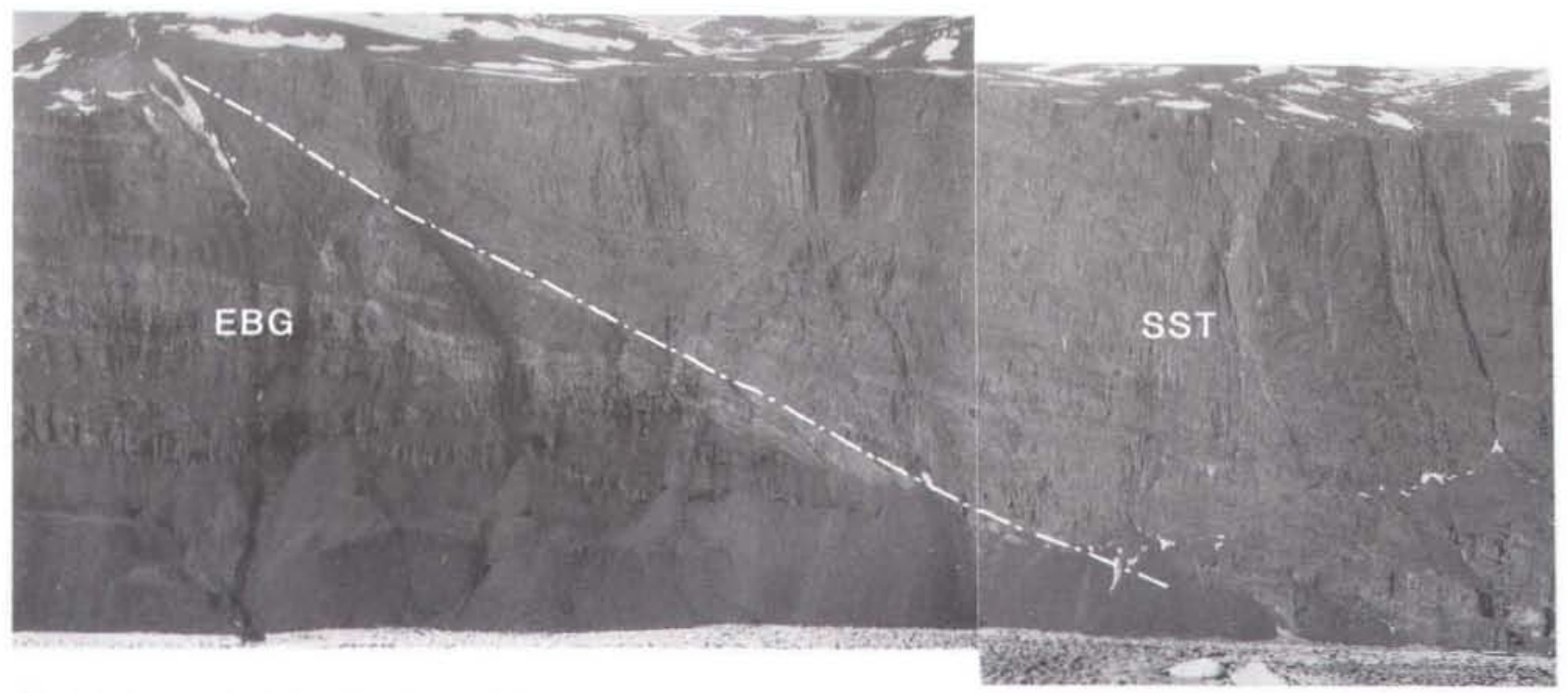

Fig. 14. Section $t$ in the Vilddal Group at Solstrand in southern Strindberg Land (see also Fig. 9). The Solstrand Formation (SST) is in fault contact with the Precambrian Eleonore Bay Group (EBG). The position of the boundary between the Solstrand 


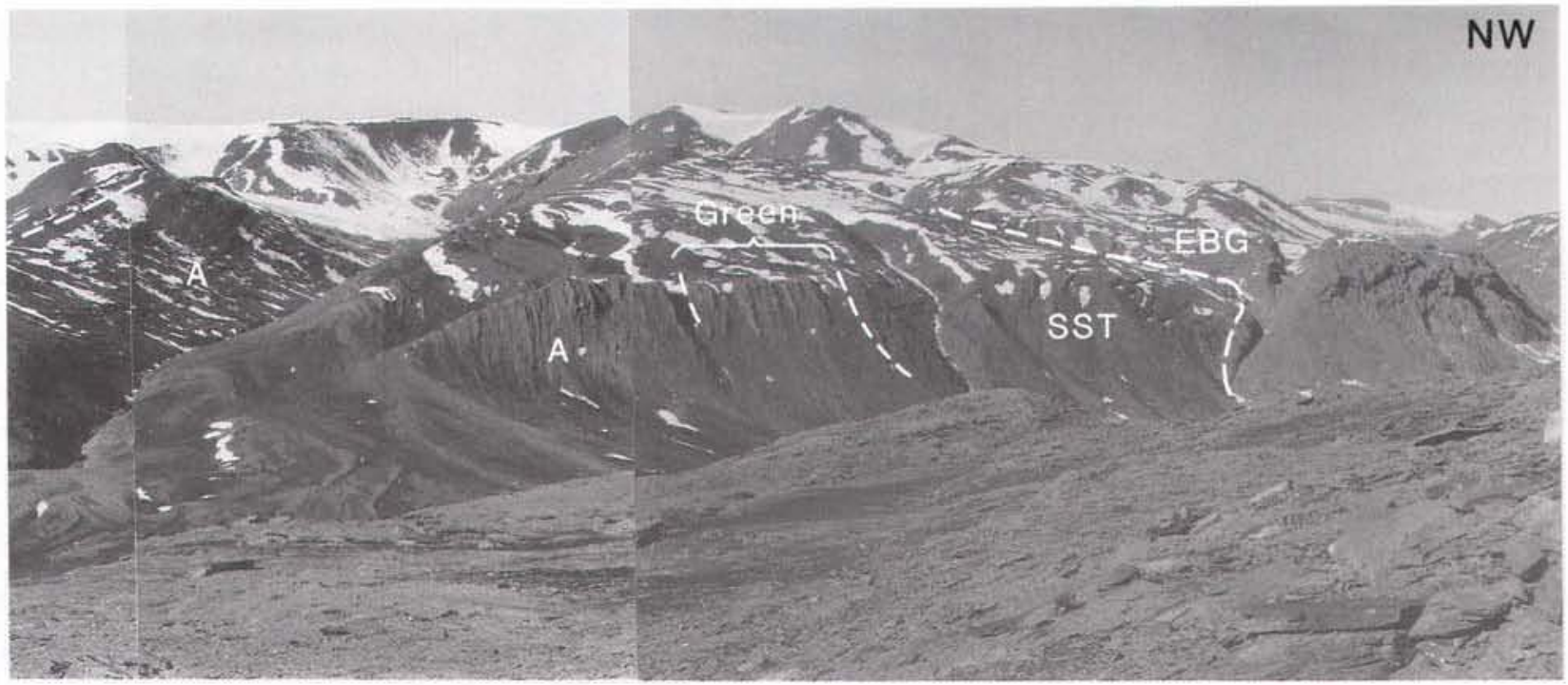

12), western Moskusoksefjord (section 3, Figs 8, 12), western Gunnar Andersson Land south of Hammeren (section 4, Figs 10,12) and Rumpen in western Dûsen Fjord (section 5, Figs 10, 12).

Detailed reference sections are shown from Solstrand, Ella $\varnothing$ and upper Ankerbjergelv (Fig. 15), Rumpen (Fig. 16) and western Moskusoksefjord (Fig. 17).

Thickness. The thickness of the formation varies greatly within the outcrop area. However, it reaches the great- est thickness on Ella $\emptyset$ and at Solstrand in Strindberg Land where more than $1000 \mathrm{~m}$ is exposed in the cliff sections.

Lithology and sedimentary structures. The formation is almost totally dominated by conglomerates with subordinate sandstones, siltstones and very rare limestones. The conglomerate beds range in thickness from $10 \mathrm{~cm}$ to $5 \mathrm{~m}$ as tabular units, or rarely with small-scale channelled base.

The bulk of conglomerates is composed predomin-

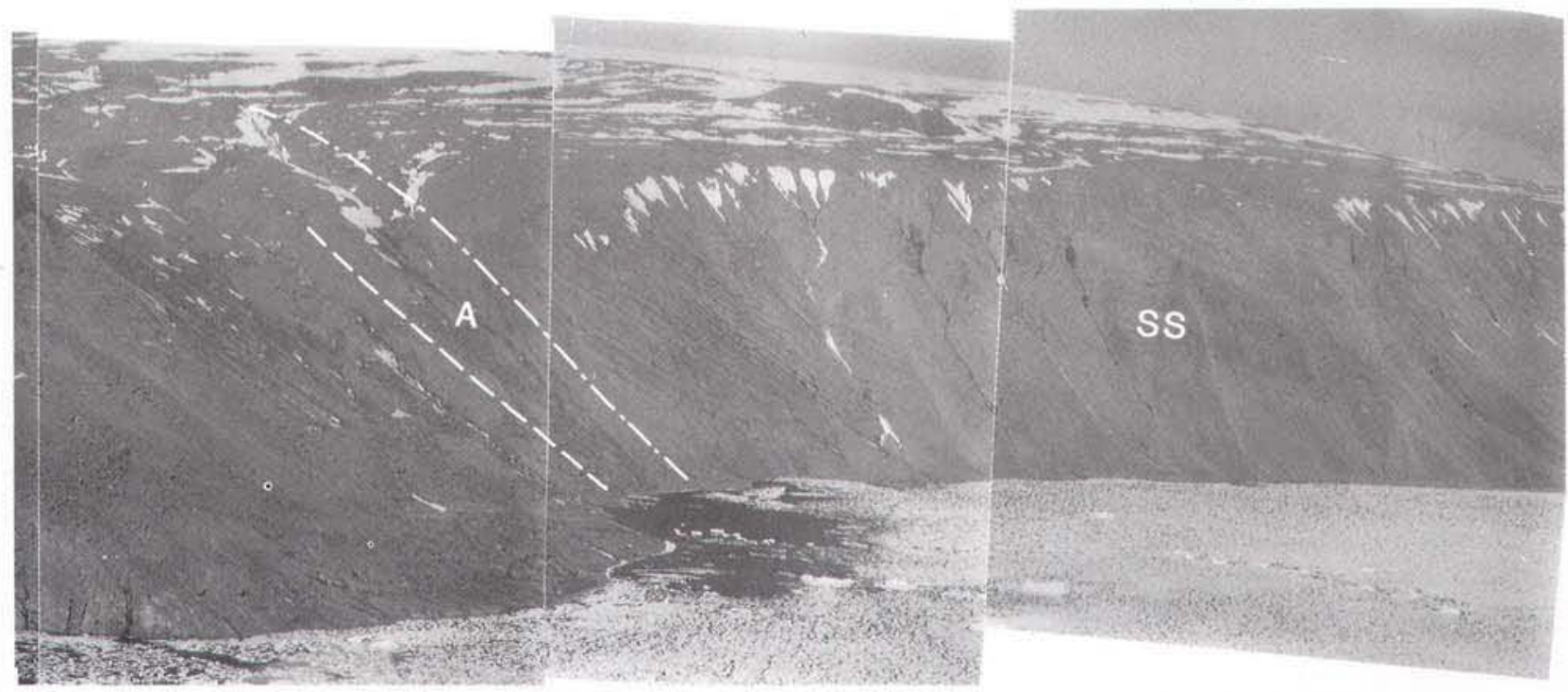

Formation and the Ankerbjergselv Formation is approximate. Height of cliff in centre of the photograph is $c .1100 \mathrm{~m}$. The view is towards NE. 


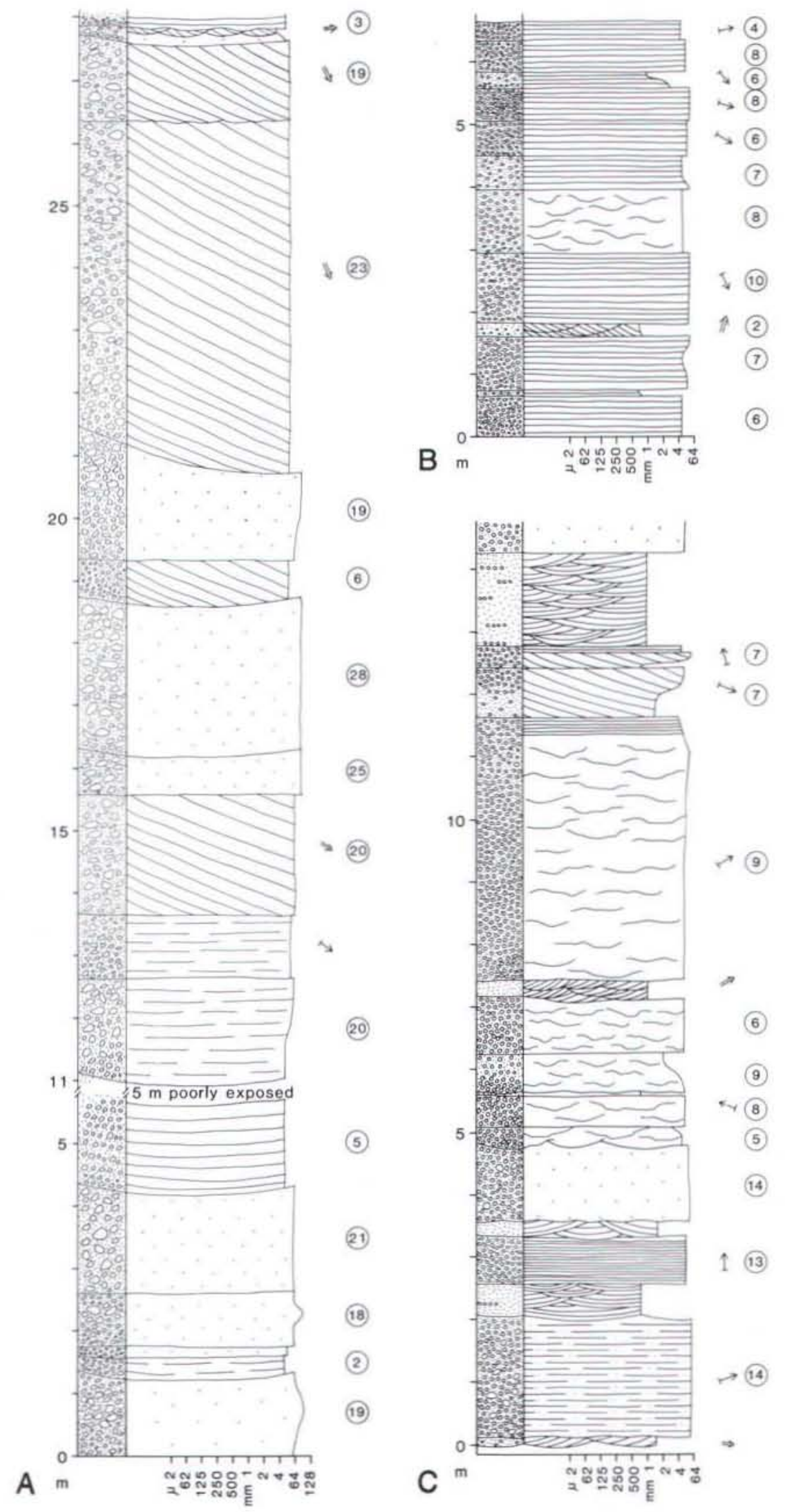

Fig. 15. Facies logs from the Solstrand Formation illustrating its typical development in different parts of the basin. A is from reference section 1 at Solstrand. measured c. $500 \mathrm{~m}$ below the top of the formation (Fig. 9). B is measured c. $100 \mathrm{~m}$ from the exposed top of the formation at Ella $\emptyset$ (reference section 2) (Fig. 12). $\mathrm{C}$ is measured c. $100 \mathrm{~m}$ above the base of the formation $2 \mathrm{~km}$ NE of the Ankerbjergselv river, close to the type section for the formation (section 6 , Figs 8, 12). Legend: Plate 2.

(6) 


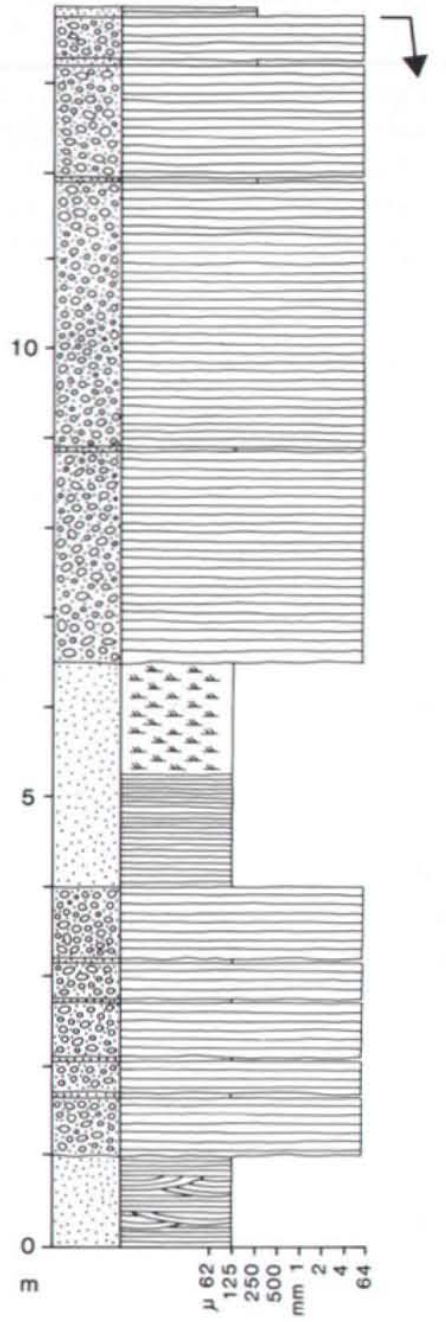

Fig. 16. Facies log from the Solstrand Formation near Rumpen (reference section 5 , Figs 10,12), illustrating the alternating conglomerate and sandstone units in the upper $50-100 \mathrm{~m}$ of the formation in western Ymer $\emptyset$. The section is measured c. $100 \mathrm{~m}$ below the top of the formation. Legend: Plate 2 .
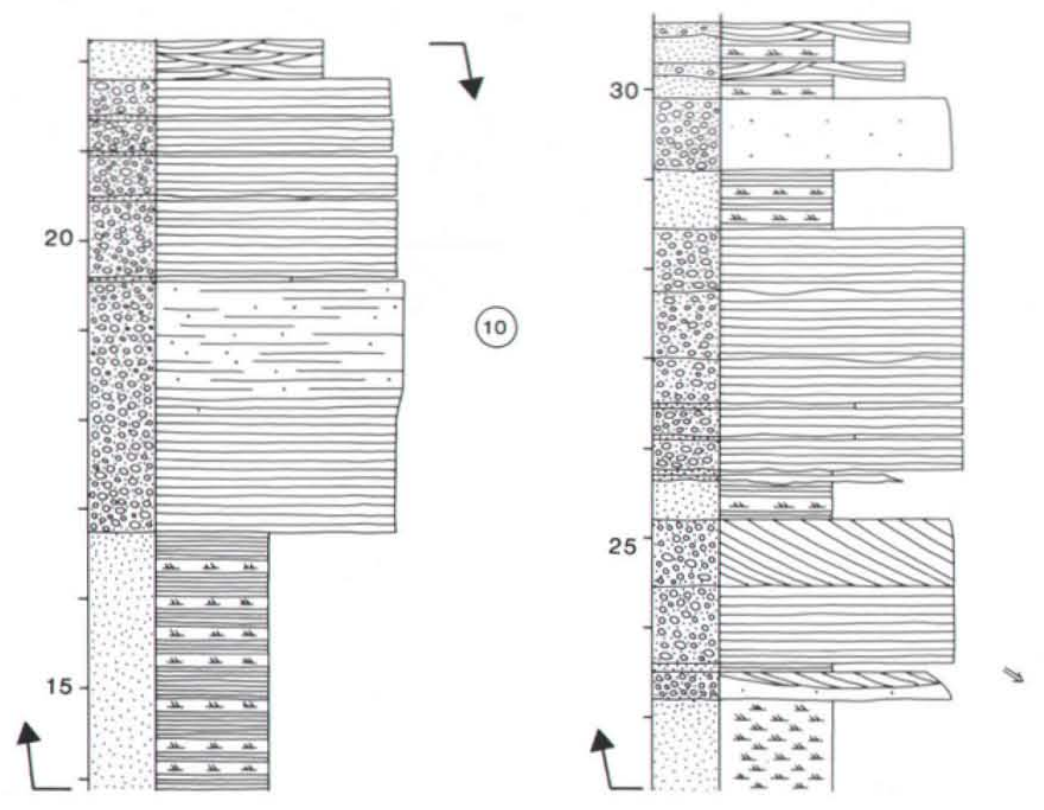

Fig. 17. Erosional base of the Solstrand Formation (SST), cut into dipping Cambro-Ordovician limestones. The photograph is taken at Torbern Bergman Bjerg looking towards the south.

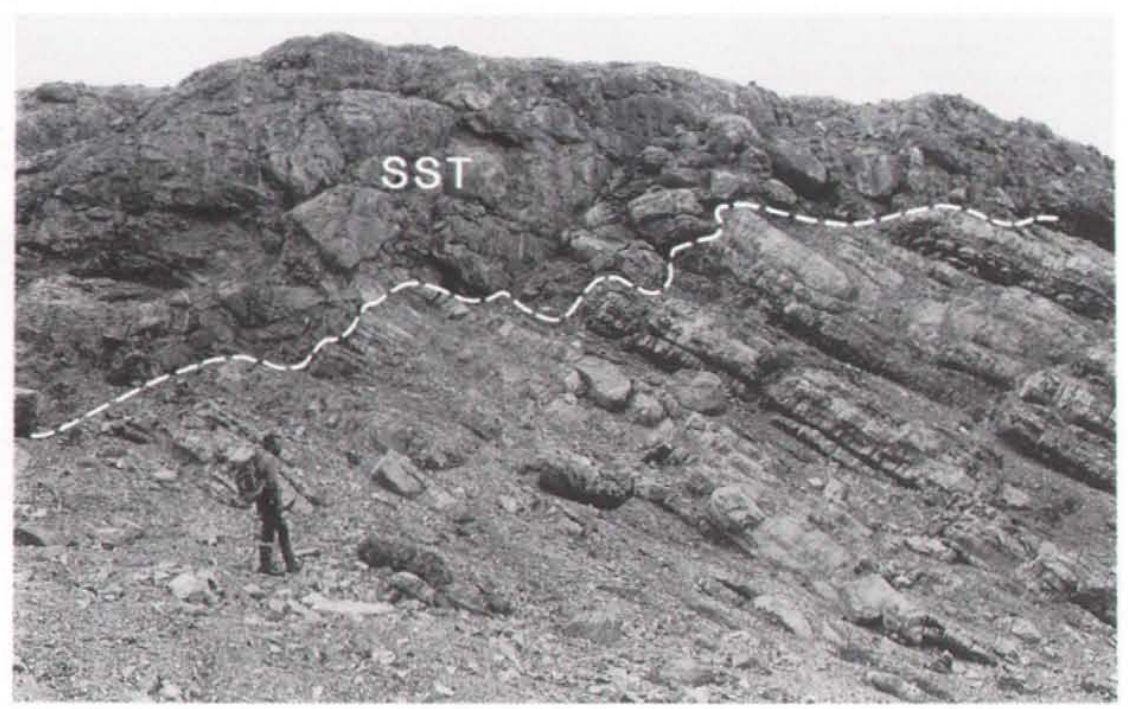




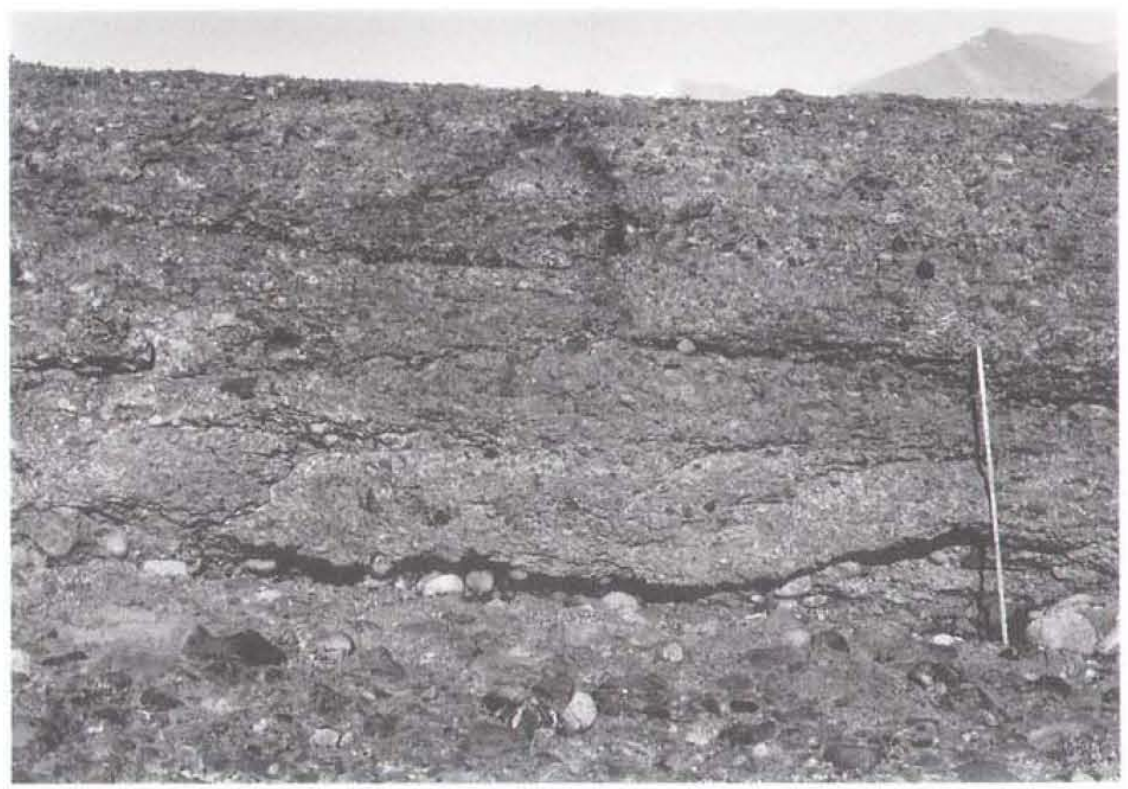

Fig. 18. Bedding characteristics of the conglomerates in the upper part of reference section 2 of the Solstrand Formation (Fig. 11). The conglomerates exhibit scour-and-fill bedding with locally developed crossbedding. The measure is $100 \mathrm{~cm}$ long. The photograph was taken on Ella $\emptyset$ c. $500 \mathrm{~m}$ below the top of section 2.

antly of black, grey and beige dolostone and limestone clasts (c. $50-95 \%$ of total clasts), together with quartzite and rare sandstone and crystalline clasts. Occasionally crystalline clasts of granite, gneiss and vein quartz, or quartzite clasts dominate with subordinate carbonate clasts. The clasts are set in a matrix of grey or red sandstone. The conglomerates weather red. Clast content is typically in the range $70-90 \%$. Usually no clearcut segregation between clasts and matrix is observed. The conglomerates are always clast-supported with angular to rounded clasts. The beds are mainly composed of pebbles with horizontal lamination, massive or structureless bedding, scour-and-fill bedding and planar and trough cross-bedding (Fig. 18). Imbrication is locally well developed. Associated pebbly sandstones occur in units $5 \mathrm{~cm}$ to $1.5 \mathrm{~m}$ thick in the western and northern outcrop areas (Ella $\varnothing$, Solstrand, Ankerbjergselv). They are red coloured and horizontally laminated and trough cross-bedded. Locally sandstones are more dominant (see below).

Minor constituents of red, green and black sandy siltstones and limestones are reported from the lowermost part of the Ella $\varnothing$ succession by (Yeats \& Friend, 1978). These beds attain thicknesses up to $7 \mathrm{~m}$. The basal few metres or tens of metres overlying preDevonian carbonates are anywhere in the basin composed of carbonate breccias with clast-size up to several metres. Such breccias also commonly occur in small gorges cut into pre-Devonian limestones.

At Ramsay Bjerg, north central Gauss Halvø (Fig. $8)$, the formation is composed of a few hundred metres of grey fine sandstones with thin siltstone interbeds
(Alexander-Marrack \& Friend, 1976). Two conglomeratic units, $30 \mathrm{~m}$ and $90 \mathrm{~m}$ thick occur in the lower and upper part of the formation, respectively (Bütler, 1959; Alexander-Marrack \& Friend, 1976).

In the east, the Kap Franklin area (Fig. 7), the formation consists of alternating grey, coarse and mediumgrained pebbly sandstones associated with green, grey and red siltstones (Alexander-Marrack \& Friend, 1976).

The upper $50-100 \mathrm{~m}$ of the formation exposed in western Ymer $\varnothing$, south of Hammeren and east of Rumpen (Fig. 10), are composed of red very fine to fine sandstones and grey conglomerates. The two lithologies alternate in units a few metres thick (Fig. 16), though in Gunnar Andersson Land in northern Ymer $\emptyset$ the sandstones may reach several tens of metres in thickness.

The upper $c .100 \mathrm{~m}$ of the formation in parts of Hudson Land ('Nordhoeksbjerg (Mixed) Sandstoneand-siltstone Formation' of Alexander-Marrack \& Friend (1976)) and on Ramsay Bjerg (upper part of Alexander-Marrack \& Friend's (1976) 'West Ramsays Bjerg Conglomerate Formation') are composed of alternating grey sandstones and red siltstones, similar in character to the formation exposed in the Kap Franklin area (Alexander-Marrack \& Friend, 1976. p. 56, 65. 66).

Depositional environments and palaeocurrents. The Solstrand Formation was mainly deposited by systems of gravelly braided rivers (Olsen, 1993). Palaeocurrents generally trend eastwards indicating a main source area, and thus a basin margin west of the outcrop area (Alexander-Marrack \& Friend, 1976; Olsen, 1993). The distal 
part of the alluvial system, exposed in the Kap Franklin area, was characterized by sandy rivers with associated silty flood basin areas. Locally apparently intra-basinal sources of material is reflected in the conglomerates by the abundance of crystalline clasts, e.g. at Ramsay Bjerg (Bütler, 1959). The change in lithology in the upper part of the formation at several localities testifies to a change from extensive gravelly river systems to gravelly and sandy rivers with flood basins in the proximal and basinal part of the system towards the end of the Solstrand Formation period. In the present outcrops there is no indication of sediments derived from the east, and thus no sedimentological evidence of an eastern margin to the basin in the vicinity of the outcrop area during deposition of the formation (AlexanderMarrack \& Friend, 1976). The basal carbonate breccias always present at the sedimentary contacts between Devonian conglomerates and pre-Devonian carbonates are interpreted as pediment and talus deposits.

Boundaries. The lower boundary is defined by the abrupt and unconformable change from underlying $\mathrm{Ca}$ ledonian crystalline or sedimentary rocks, often limestones of Cambro-Ordovician and Precambrian age to reddish weathering breccias or conglomerates of the Solstrand Formation (Fig. 17). In the Kap Franklin area (Fig. 7), the lower boundary of the formation is not exposed.

The top of the formation is transitional to the Ankerbjergselv Formation in eastern Hudson Land, Strindberg Land and parts of Ymer $\emptyset$. The boundary is here taken at the base of the first green sandstone (locally yellowish weathering) of the Ankerbjergselv Formation. At Ramsay Bjerg and in the Kap Franklin area the formation is also transitional to the Ankerbjergselv Formation. Here it is defined as the base of the green, greenish grey or greenish black siltstones or mudstones of the overlying Ankerbjergselv Formation. At other localities the formation is unconformably overlain by the Kap Kolthoff Group. This is observed in western Hudson Land, where red conglomerates of the Snehvide Formation (see below) overlies the Solstrand Formation. In parts of Ymer $\varnothing$ green sandstones of the Sofia Sund Formation onlap on the Solstrand Formation.

Distribution. In the study area the formation is exposed in Hudson Land, Gauss Halvø, southern Strindberg Land, western Ymer $\varnothing$ and on Ella $\varnothing$ (Figs 6, 8-11). Outliers only briefly examined by the authors occur on Hammar $\varnothing$, Aakerblom $\varnothing$ and in the Syltoppene area (see also Larsen, 1990a).
Grological age. Spores and megaspores from the lowermost part of the formation on Ella $\varnothing$ indicate a Givetian age (Allen, 1972; Friend et al., 1983).

\section{Kap Bull Formation new formation}

History. This formation includes Bütler's (1934, 1959) 'Konglomerat 1' of his 'Basis Series', 'Konglomerat 2' of his 'Kap Bull Series' (later termed 'Ramsey Bjerg Series' and 'Konglomerat 3' of his 'Kap Kolthoff Series'. The formation forms part of Alexander-Marrack \& Friend (1976) and Friend et al.'s (1983) Vilddal Supergroup. Koch \& Haller (1971) includes the formation in the 'Middle Devonian' mapping unit.

Name. After the cape in SW Hudson Land at the mouth of Moskusoksefjord (Fig. 8).

Type section. The type section is at the 'Moskusoksefjord inlier' (Bütler, 1959) on Gauss Halvø north of Flett Plateau, south of the Genvejsdalen delta on the opposite-side of the Moskusoksefjord (section 3, Figs 8 . 12, 19). No reference sections were measured.

Thickness. The thickness, measured perpendicular to the steeply dipping base and top attains a maximum of less than $500 \mathrm{~m}$ in the type section area (Figs 8, 12), wedging out completely towards the west. The exposed stratigraphic thickness is $c .1000 \mathrm{~m}$.

Lithology and sedimentary structures. The formation is dominated by conglomerates with subordinate sandstones. The clasts are pebble and cobble-sized and dominated by granites with subordinate dolostone and limestone clasts. The clasts are set in a matrix of red sandstone and clast content is typically $70-90 \%$. The conglomerates are clast-supported with angular to rounded clasts. The rocks weather red. The formation is almost entirely composed of stacked coarsening and coarsening-to-fining upward cycles in the order of 10$100 \mathrm{~m}$ thick (Figs 19, 20, 21). These cycles are composed of very fine to medium-grained red (and grey) sandstones with only thin conglomerates in their lower $c$. 1-5 $\mathrm{m}$ overlain by thick successions of tabular conglomerate beds in the order of 1-2 m thick with or without centimetre thick sandstone partings. The tops of cycles are sometimes fining upwards and composed of decimetre thick conglomerate beds with centi- to decimetre thick sandstone partings. The dominating sedimentary struc- 
Fig. 19. Facies log from the Kap Bull Formation at the north coast of Gauss Halvø in western Moskusoksefjord above the 'inlier' (reference section 3, Figs 8 , 12, 20). It illustrates coarsening and coarsening-to-fining upward cycles dominating the succession at this locality. Legend: Plate 2.
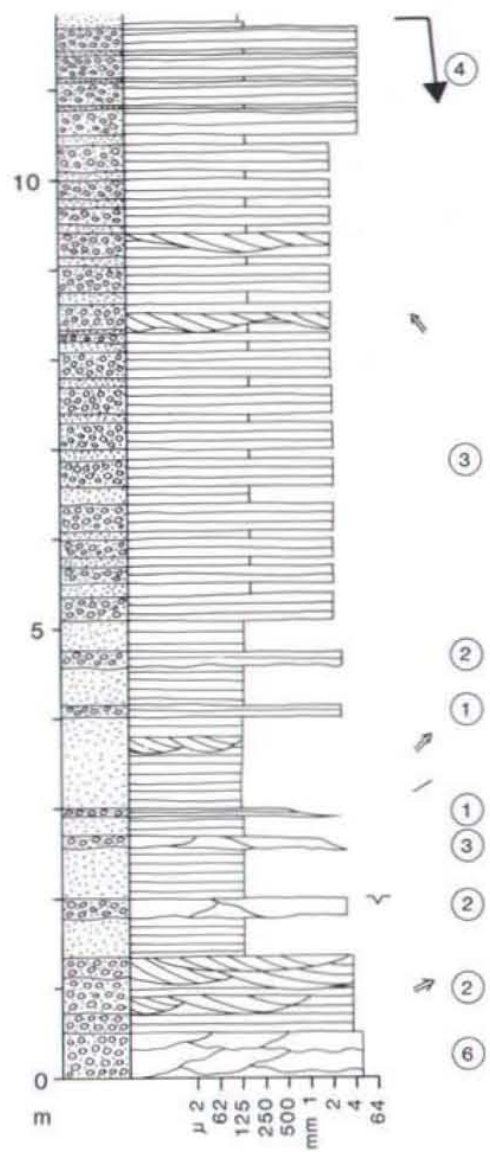

(3)
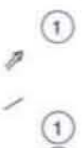

(1)

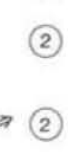

(6)
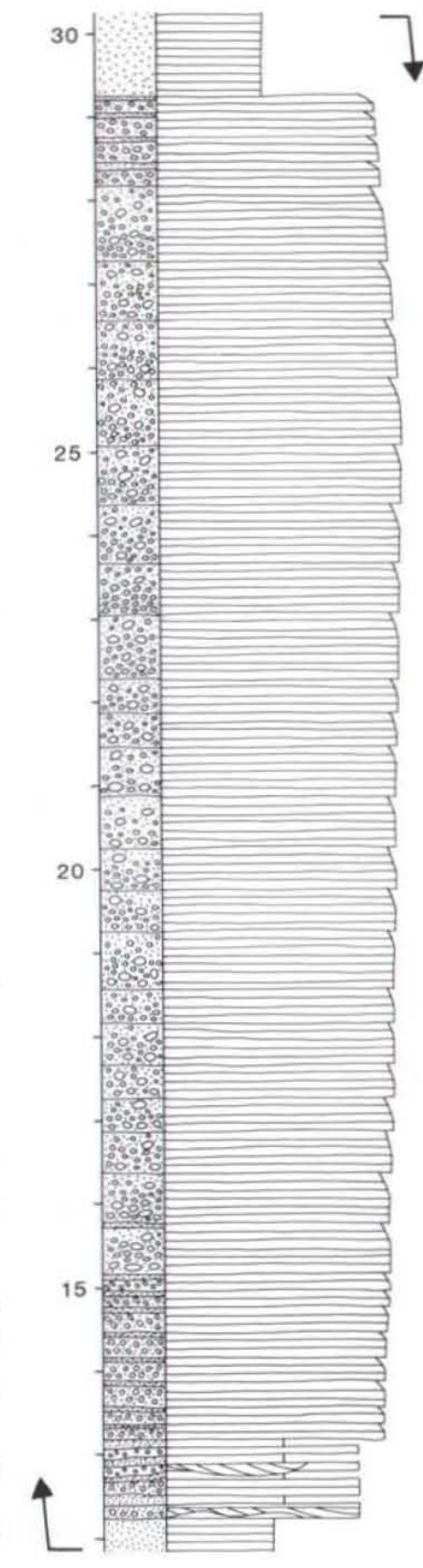

(8)

(12)

(13)

(12)

(12)

(12)

(6)

(7)

(4)

(4)

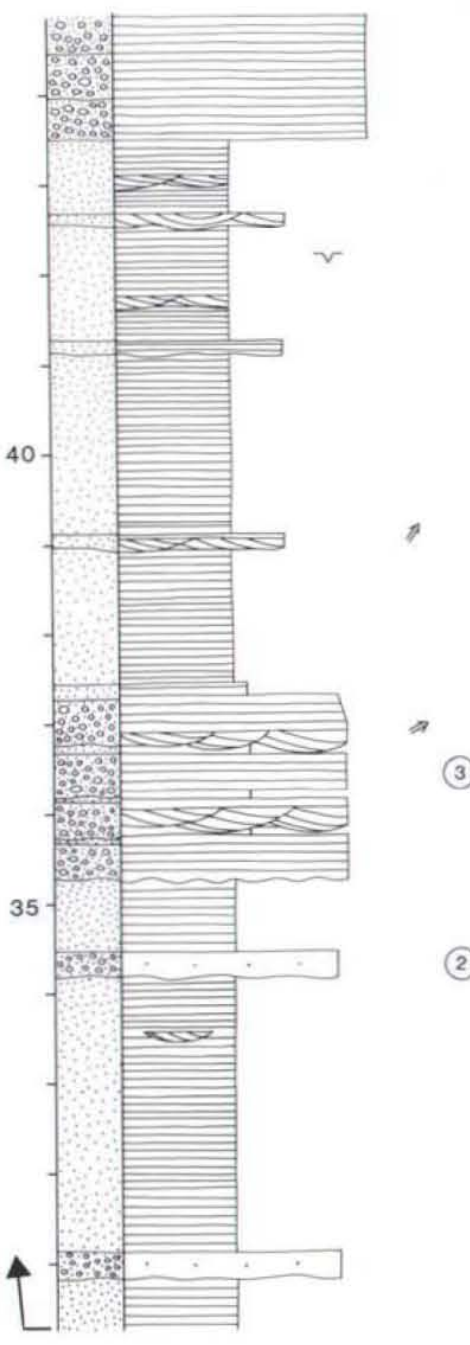

ture in both conglomerates and sandstones is horizontal lamination (Fig. 19). An internal angular unconformity occurs between these stacked cycles and the overlying Genvejsdalen Member, described below (Figs 20, 21). The basal few metres of the formation are locally developed as carbonate breccias, corresponding to the 'Konglomerat 1' of Bütler (1935, 1959).
Depositional environments and palaeocurrents. The Kap Bull Formation is interpreted as predominantly alluvial fan deposits (Olsen, 1993). Individual coarsening and coarsening-to-fining upward cycles reflect repeated progradational to retrogradational alluvial fans. The localized nature of these deposits in the interior of the basin suggests an intra-basinal origin. The basal breccias are 
Fig. 20. Eastward tilted sediments of the Kap Bull Formation (KB) resting on crystalline rocks (CRYST) of the 'inlier' in Gauss Halvø. Moskusoksefjord is seen in the foreground. Location of reference section 3 is indicated. The tilted Kap Bull Formation is unconformably overlain by the Genvejsdalen Member (G) which is onlapped by sediments of the Kap Kolthoff Group: the Langbjerg (L) and Sofia Sund Formations (SS). The Watson Plateau Member (WP) tops the mountains. Length of coast line is $c .2 \mathrm{~km}$.

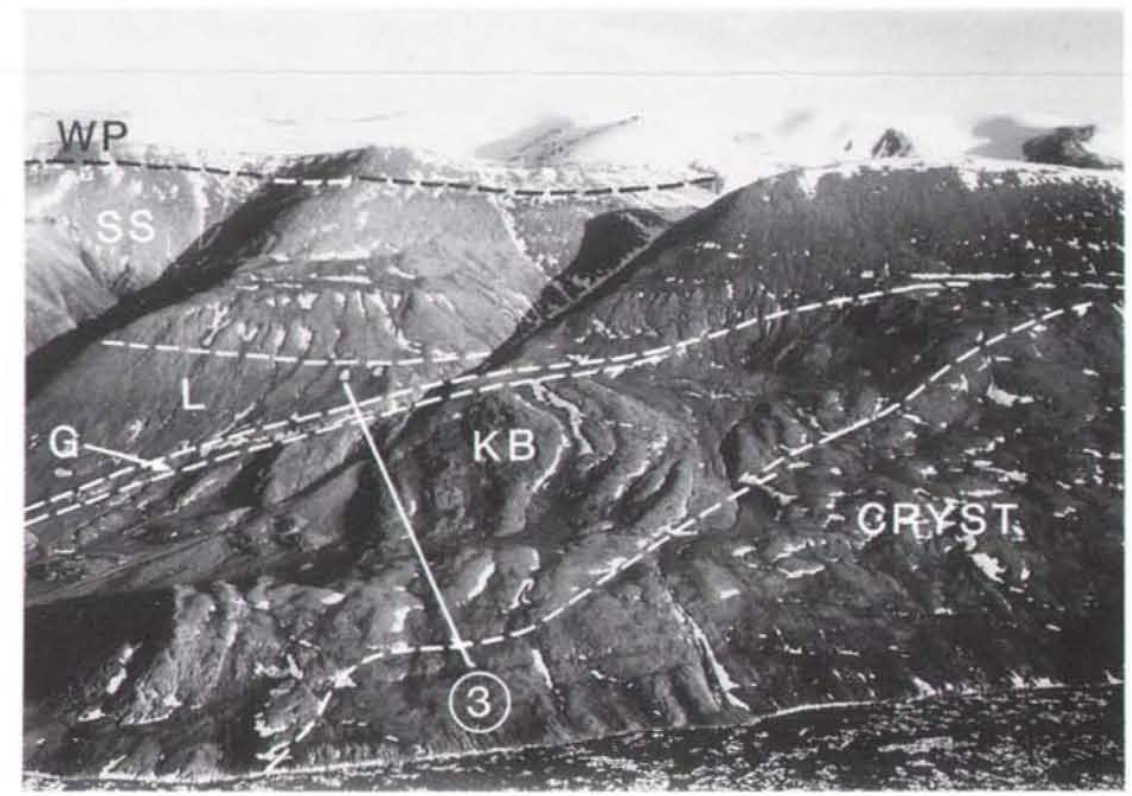

interpreted as talus deposits. Palaeocurrents are towards NE.

Boundaries. The lower boundary is defined by the abrupt and unconformable change from underlying $\mathrm{Ca}$ ledonian crystalline rocks and locally Cambro-Ordovician carbonates to reddish weathering conglomerates of the Kap Bull Formation (Fig. 20). The upper boundary is also an unconformity with onlapping red, green and grey sandstones of the Langbjerg and Sofia Sund Formations, Kap Kolthoff Group (Fig. 20).

Distribution. The formation is restricted to the western part of Moskusoksefjord, mainly east of the 'inlier' (Fig. 8); see also Larsen, 1990a).

Geological age. No fossils were discovered in the Kap Bull Formation. A Middle Devonian age is inferred on
Fig. 21. Close-up of bedding relationships at the 'inlier' from the same locality as Fig. 20. The Kap Kolthoff Group (KK GRP) onlaps the Genvejsdalen Member (G) of the Kap Bull Formation. The Genvejsdalen Member rests unconformably on tilted sediments of the Kap Bull Formation (KB), here represented by a coarsening upward cycle of sandstone and conglomerate (up is towards the left).

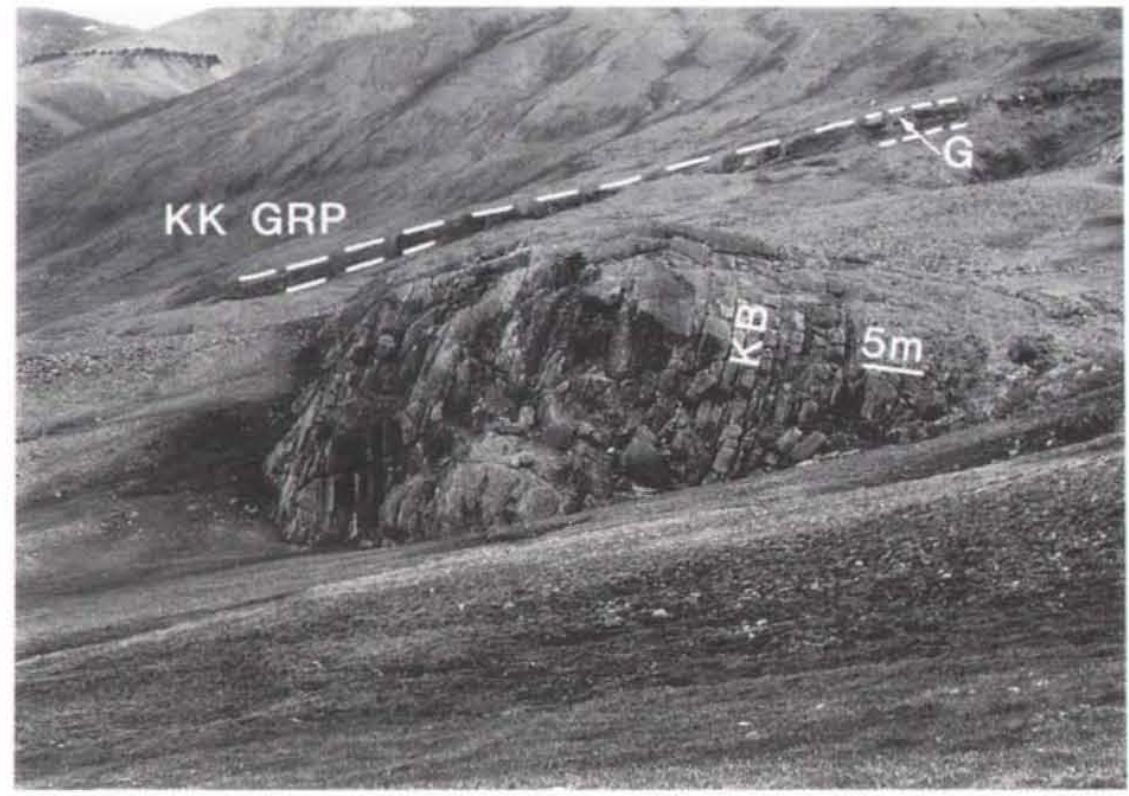


the basis of the position unconformably below the Langbjerg Formation. It is tentatively interpreted to be synchronous with the Solstrand Formation.

Subdivisions. One member is defined, the Genvejsdalen Member (Plate 1), overlying an internal unconformity and forming the topmost c. $25 \mathrm{~m}$ of the formation.

\section{Genvejsdalen Member new member}

History. The member is equivalent to 'Konglomerat 3 ' of Bütler $(1935,1959)$ in the western Moskusoksefjord area. It was indicated as 'Middle Devonian' by Koch \& Haller (1971) and referred to the Kap Kolthoff Group by Friend $e t$ al. (1983, locality 10).

Name. After the valley, Genvejsdalen, in western Moskusokselandet (Fig. 8).

Type section. The type section is at the 'Moskusoksefjord inlier' (Bütler, 1959) on Gauss Halvø north of Flett Plateau, south of the Genvejsdalen delta on the opposite side of the Moskusoksefjord (section 3, Figs $12,20,21)$. No reference sections were measured.

Thickness. The member attains a thickness of approximate $25 \mathrm{~m}$.

Lithology and sedimentary structures. The member is composed of a cobble-size conglomerate dominated by very angular clasts of banded gneiss and 'augen-gneiss', with subordinate granite and schist clasts and less than $10 \%$ carbonate clasts. The conglomerate is clast-supported with a red, weathering green, fine-grained sandstone matrix. The conglomerate beds are decimetre to metre scale thick and generally massive. Rare channelshaped $10-15 \mathrm{~m}$ wide and $1-1.5 \mathrm{~m}$ thick channel-shaped units with very fine to fine-grained red sand are associated with the conglomerates.

Depositional environments. The Genvejsdalen Member was deposited by gravelly braided rivers, probably representing the distal equivalent to the alluvial fans of the Kap Bull Formation (Olsen, 1993). No palaeocurrent directions were obtained.

Boundaries. The lower boundary is an angular unconformity to the underlying conglomerates and sandstones ('Konglomerat 2' of Bütler, 1935, 1959) of the Solstrand Formation. The upper boundary is also an unconformity with onlapping red, green and grey sandstones of the Langbjerg and Sofia Sund Formations, Kap Kolthoff Group (Fig. 19).

Distribution. The member is restricted to the western part of Moskusoksefjord, east of the 'inlier' (Fig. 18; Larsen, 1990a).

Geological age. No fossils were discovered in this member. A Middle Devonian age is inferred.

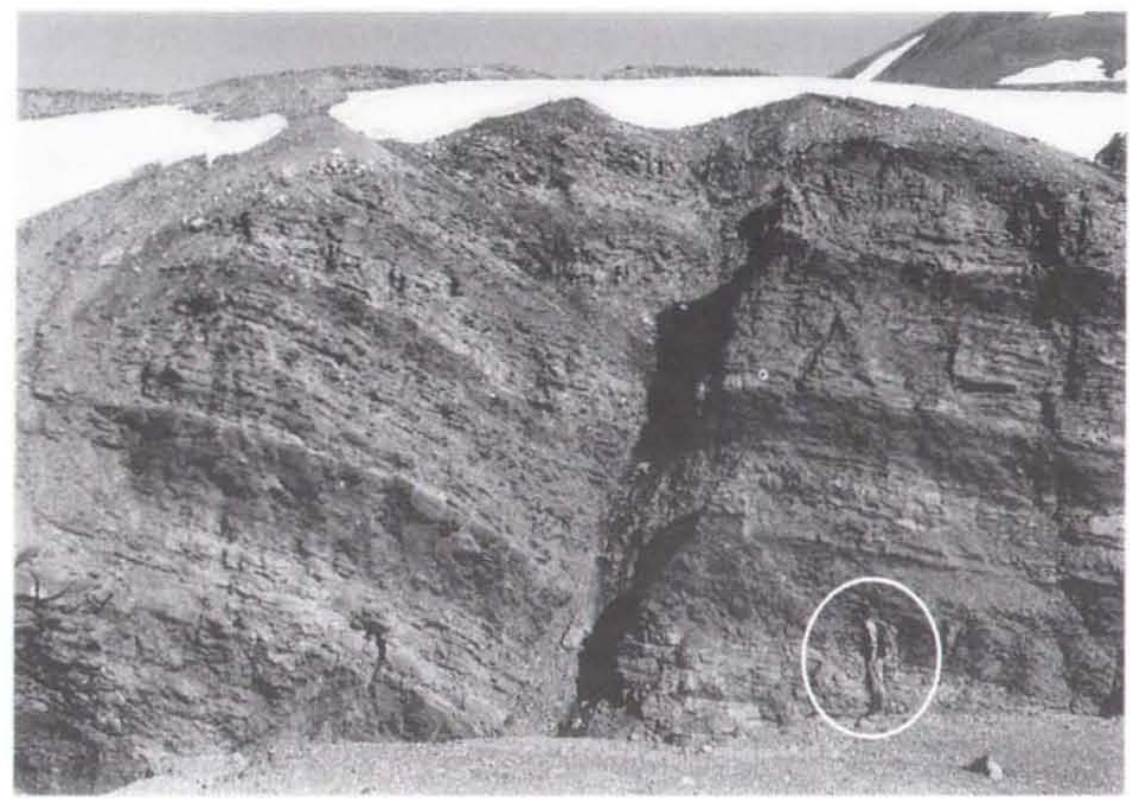

Fig. 22. The characteristic alternation of red (dark coloured on the photograph) and green units in the Ankerbjergselv Formation in western Gunnar Andersson Land immediately north of reference section 4 (Fig. 10). The sediments in this section are all composed of sandstones. Person for scale. The view is towards the east. 


\section{Ankerbjergselv Formation} new formation

History. The formation includes the 'Inderdalen Formation', the 'Nordhoeksbjerg Red-and-green banded Siltstone Formation', the 'Nordhoeksbjerg Green Sandstone Formation', the 'Nordhoeksbjerg (Mixed) Sandstone-and-Siltstone Formation', the 'Ramsays Bjerg Red-and-green banded Siltstone' the 'Karins Dal Grey Siltstone (Formation)' and the 'Vilddal Red-and-green banded Siltstone (Formation)' in the sense of Alexander-Marrack \& Friend (1976) and Friend et al. (1983) (Fig. 5). It includes the "greyish-green, reddishstreaked sandstone series" (Bütler, 1959, p. 167) forming the upper part of his 'Basis Series' (Bütler, 1954, 1959). The formation also includes the "greyish-green ... fine-grained strata interbedded with red bands" (Bütler, 1959, p. 169) comprising the upper part of his 'Vilddal Series' (Bütler, 1954, 1959, 1961) (Fig. 4). It is suggested that these older names are abandoned primarily because they merely served as geographic subdivisions of one genetic unit.

Koch \& Haller (1971) included the formation as part of the 'Middle Devonian' (Fig. 4).

Name. The formation name is after Ankerbjergselv in Hudson Land (Fig. 8).

Type and reference sections. The type section is measured around Ankerbjergselv in Hudson Land (section 6 , Figs $8,12,13$ ). Reference sections are located in western Ymer $\emptyset$ (sections 4 \& 5, Figs 10, 12) and at Solstrand in southern Strindberg Land (section 1, Figs 9, 12). Detailed sections were measured at Solstrand (Fig. 22), south of Hammeren in western Gunnar Andersson Land (Fig. 24) and in the Ankerbjergselv area (Figs 25, 26, 27).

Thickness. A preserved thickness of approximately 1800 $\mathrm{m}$ has been measured in Hudson Land. Along the western basin margin the preserved thickness of the unit is less and does not exceed $2-300 \mathrm{~m}$.

Lithology and sedimentary structures. The formation is generally characterized by an alternation on a 5-100 m

Fig. 23. Facies logs from the Ankerbjergselv Formation illustrating the close association of red sandstones and grey conglomerates, alternating with green sandstone units. Reference section 1 at Solstrand (Fig. 12), measured c. $200 \mathrm{~m}$ from the fault bounded top of the formation (Fig. 9). Legend: Plate 2.

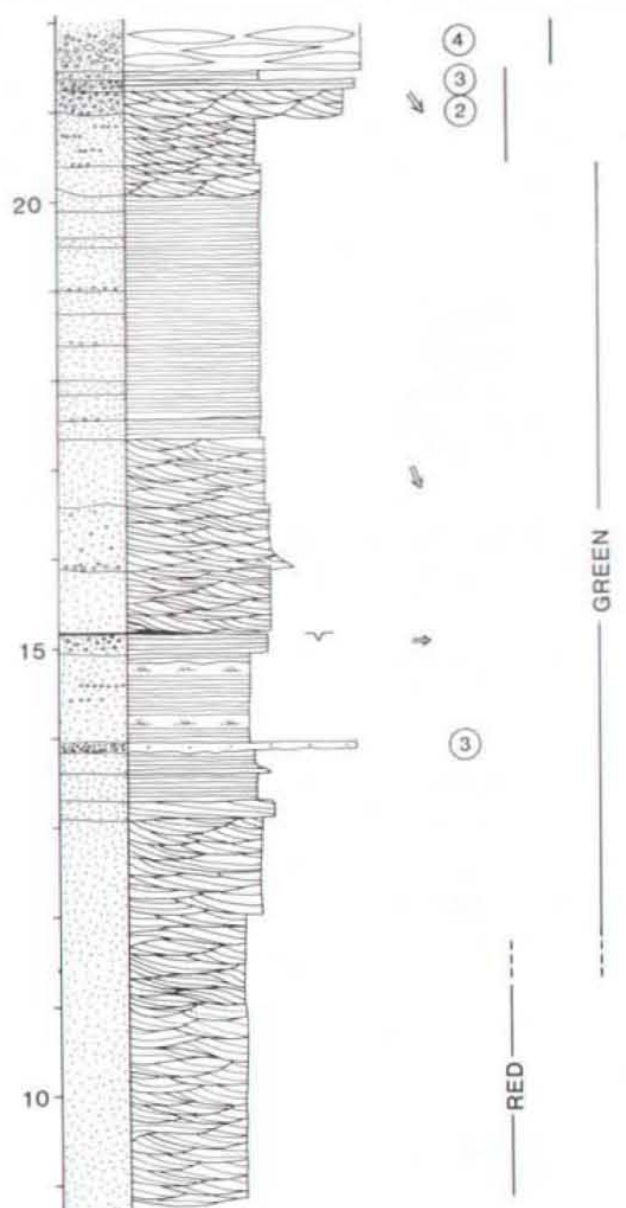

㟧

(1)

-




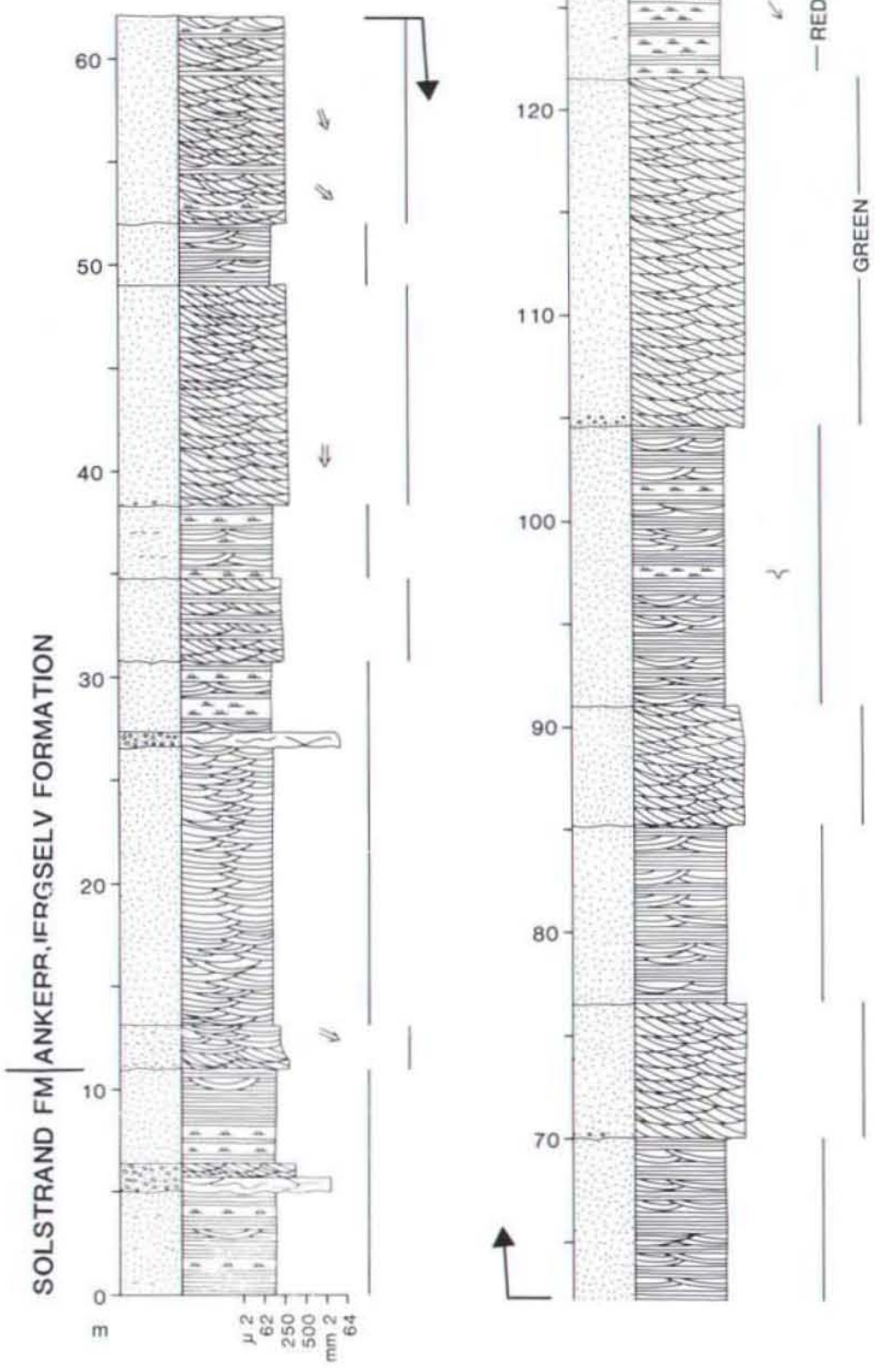

Fig. 24. Facies log from the Ankerbjergselv Formation illustrating the alternation of red sandstones (with thin conglomerate beds) and green sandstones in reference section 4. western Gunnar Andersson Land (Figs 10. 12). Legend: Plate 2.

scale of red and green sandstones and siltstones (Fig. 22) though thicker green and grey units also occur.

In western Ymer $\emptyset$ and southern Strindberg Land the formation is composed of an alternation on a $5-30 \mathrm{~m}$ scale of green sandstones and red sandstones (with associated conglomerates) (Fig. 23). The red units are composed of very fine and fine-grained sandstones with interbedding of trough cross- bedding and parallel lamination and subordinate cross-lamination (Fig. 24). The red units are closely associated with grey conglomerates (weathering red) in fining upward beds $0.5-2 \mathrm{~m}$ thick, forming units up to $5 \mathrm{~m}$ thick. The green sandstones are medium to coarse-grained and dominated by trough cross-bedding. Horizontal lamination and cross-lamination are associated with the trough-cross-bedding.

In the Ankerbjergselv area the formation starts with a c. $300 \mathrm{~m}$ thick green medium-grained pebbly sandstone unit dominated by trough cross-bedding and associated with parallel laminated sandstones and massive to parallel laminated conglomerates (Fig. 25; the 'Nordhoeks Bjerg Green Sandstone Formation' of Alexander-Marrack \& Friend (1976)). These sediments are overlain by alternating green and red units (3-30 m scale) composed of units of green medium and coarse-grained sandstones 
A

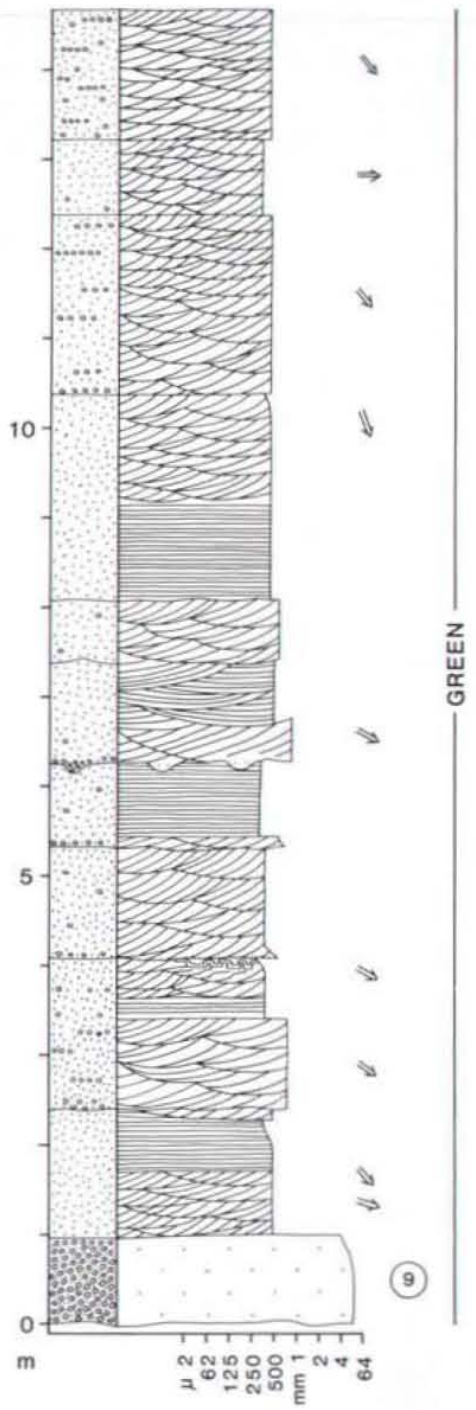

B

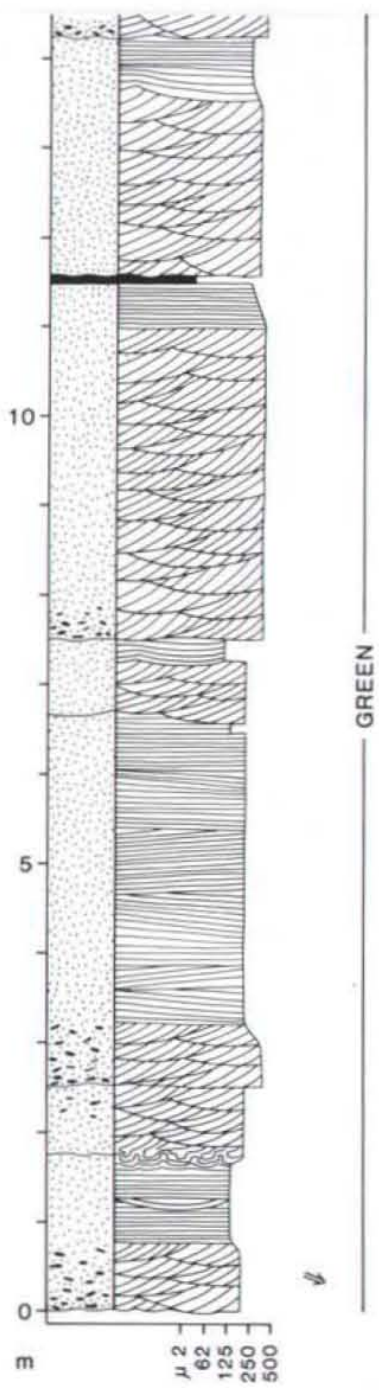

C

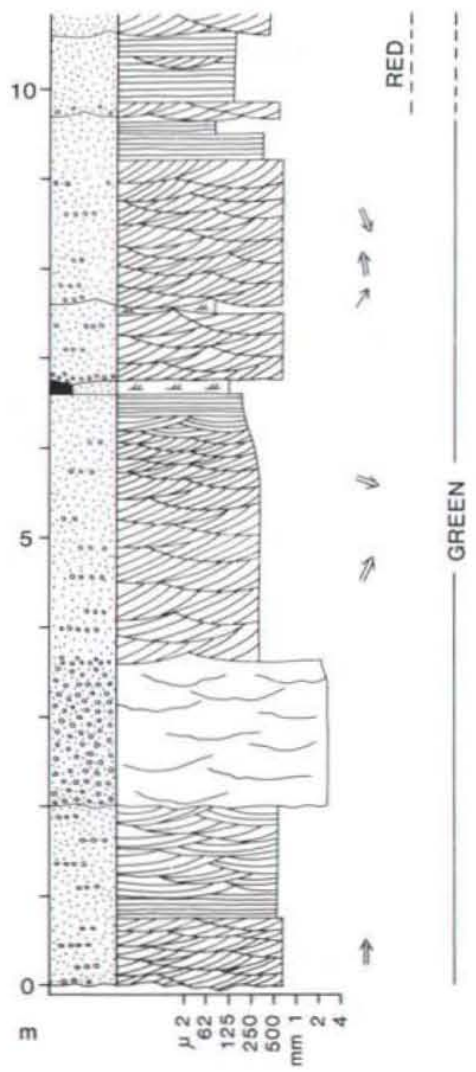

Fig. 25. Facies logs illustrating the typical characteristics of the Ankerbjergselv Formation in the Ankerbjergselv area, Hudson Land (Fig. 8). A is from the $c .300 \mathrm{~m}$ thick succession of green sandstone forming the lower part of the formation in the type section in upper Ankerbjergselv (Fig. 13; section 6, Fig. 12). B is measured c. $2 \mathrm{~km}$ north of the junction between Forbindelsesdal and Ankerbjergselv c. $100 \mathrm{~m}$ below the unconformable top of the formation. Green sandstones dominate in this part of the formation. $\mathrm{C}$ is from the type section 6 (Figs 8,12 ), c. $1200 \mathrm{~m}$ above the base of the formation. Legend: Plate 2.

associated with very fine and fine-grained green sandstones, green and grey siltstones and rare black bituminous shales and limestones alternating with units of red siltstones and very fine to fine-grained sandstones and rare coarser sandstones (Figs 26, 27; the 'Nordhoeks Bjerg Red-and-green banded Siltstone Formation' of Alexander-Marrack \& Friend (1976)). The green sandstones are dominated by trough cross-bedding with locally abundant parallel lamination. They commonly occur in fining upward units generally $1-5 \mathrm{~m}$ thick topped by centi- or decimetre thick siltstones with rare desiccation cracks. The red units are mainly composed of decimetre thick parallel laminated very finegrained sandstone and siltstone beds with common desiccation cracks. Occasionally finer-grained beds in medium and coarse-grained green sandstone units are red coloured.

The alternation of green and red units is $c .1500 \mathrm{~m}$ thick in the northwestern part of the Ankerbjergselv valley where it is unconformably overlain by the Vergys 


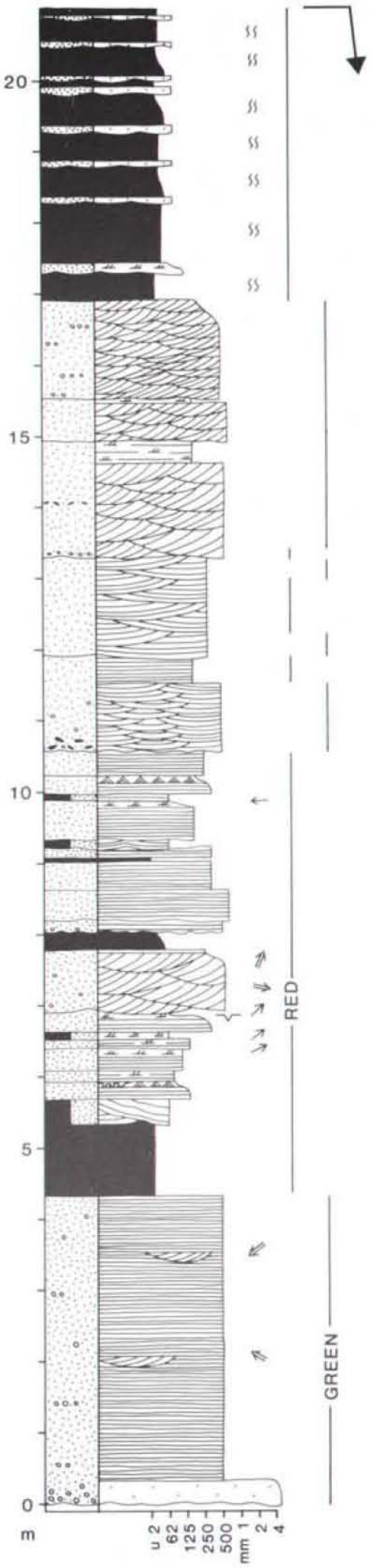

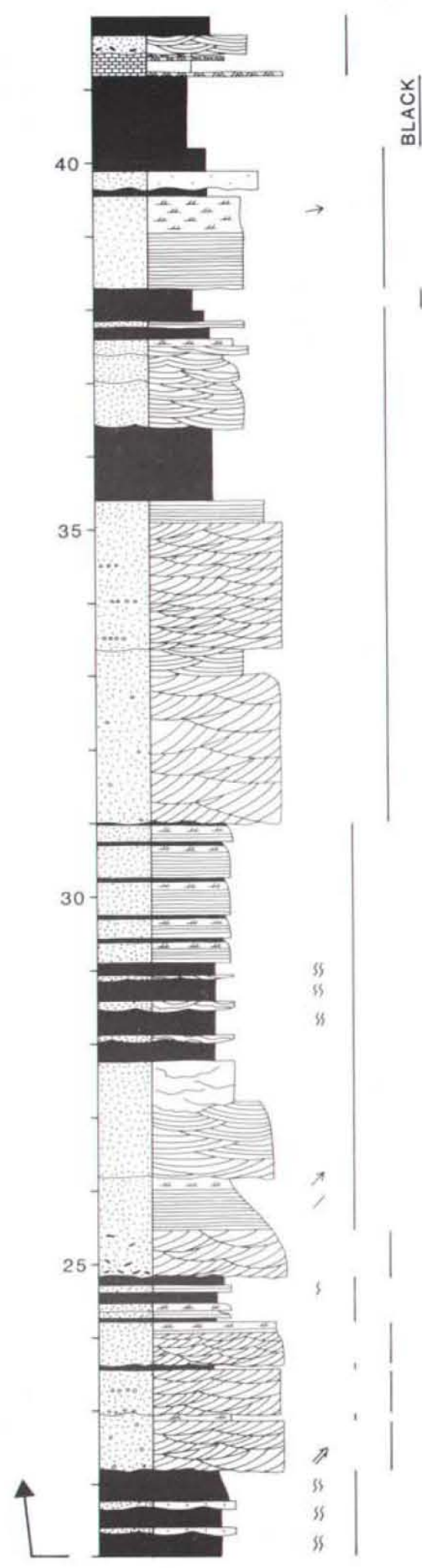

Fig. 26. Facies log exhibiting the typical development of the Ankerbjergselv Formation in the type section (section 6, Figs 8. 12; upper Ankerbjergselv). Green sandstone units alternate with red finer grained units. Thin black shale units occur in one of the green units.

I The $\log$ is measured c. $500 \mathrm{~m}$ above the base of the formation. Legend: Plate 2.
Formation (Kap Kolthoff Group). In the southeastern part of the valley an apparently thicker succession is exposed. Here the formation is dominated by green sandstones with red sandstones and siltstones forming important contributions only in the upper part below the contact to the Vergys Formation. 


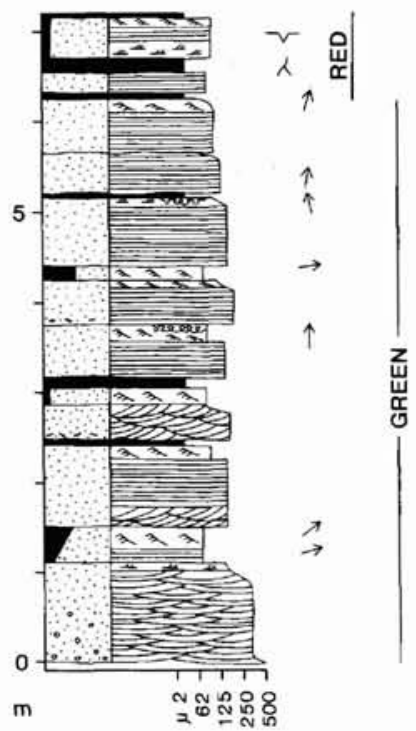

Fig. 27. Facies log from the type section of the Ankerbjergselv Formation, showing the occasional dominance of a green unit by very fine to fine-grained sandstone with horizontal lamination. The $\log$ is measured c. $1100 \mathrm{~m}$ above the base of the formation in section 6 (Figs 8,12) in upper Ankerbjergselv. Legend: Plate 2.

The formation was not studied in detail by us in the Stordal area, but seems to be similar to the northwestern Ankerbjergselv deposits, except for the colour banding which is on a scale larger than $60 \mathrm{~m}$ (Alexander-Marrack \& Friend, 1976).

In the eastern Moskusoksefjord area at Högbom Bjerg and Ramsay Bjerg the formation is dominated by green siltstones and very fine to fine sandstones with parallel lamination, cross-lamination and minor trough cross-bedding. These sediments are associated with red siltstones and very fine sandstones. No detailed sedimentological investigations were carried out in this area by us. On Agassiz Bjerg SE of Ramsay Bjerg (Fig. 18) the formation is characterized by red and green siltstones and very fine sandstones alternating on a scale larger than $60 \mathrm{~m}$ (Alexander-Marrack \& Friend, 1976).

In the Kap Franklin area (Fig. 7) the formation starts with c. $400 \mathrm{~m}$ of greenish grey or green parallel laminated mudstones with coarse siltstone and silty very fine sandstone beds, $10-50 \mathrm{~cm}$ thick and dominated by massive bedding. These are the 'plattige Sandsteine' of Bütler (1954) and the 'Vilddal Grey Siltstone Formation' of Alexander-Marrack \& Friend (1976). Also black silty shales occur in the lower part of this succession. The mudstones and shales exhibit abundant desiccation cracks and rare bioturbation. The grain-size variation is cyclic on a scale of $c .20$ metres (Alexander-Marrack \&
Friend, 76). These sediments are overlain by a sequence of c. $750 \mathrm{~m}$ of red and green-banded, parallel laminated and cross-laminated siltstones and very fine-grained sandstones (Alexander-Marrack \& Friend, 1976). Black shaly siltstones are common in some of the green intervals, often associated with vertebrate (Fish) fragments. The gross colour banding is on a scale of 10-30 metres. These sediments are the 'gebänderte Sandsteine' of Bütler (1954, p. 108) and the 'Vilddal Redand-green banded Siltstone Formation' of AlexanderMarrack \& Friend (1976, p. 17).

Depositional environments and palaeocurrents. The red and green colour banding, typical of the formation, is interpreted as reflecting primary different depositional environments (Olsen, 1993). The green sandstones in the western outcrop area (Ymer $\varnothing$, Strindberg Land) were deposited by braided rivers. In Hudson Land the green sandstones were mainly deposited on point bars in meandering rivers except for the lower c. $300 \mathrm{~m}$, which were deposited by braided rivers. The associated siltstones, shales and limestones (green, grey and black) probably represent deposition in flood basin lakes. The green, grey and black siltstones, very fine-grained sandstones and shales in the eastern Moskusoksefjord and Kap Franklin areas were probably deposited in shallow fluvial channels and lakes (Alexander-Marrack \& Friend, 1976). Palaeocurrents in the dominantly green intervals are generally eastwards in the whole outcrop area (Alexander-Marrack \& Friend, 1976; Olsen, 1993). Collectively the dominantly green deposits (including grey and black) are interpreted as representing braidplains in the west grading into meandering river plains and finally terminal flood basins with lakes in the east (Olsen, 1993).

The red sandstones and associated conglomerates in the western outcrop area are interpreted as ephemeral streams and braided rivers. The red very fine-grained sandstones and siltstones in the central and eastern part of the outcrop area are interpreted as sheetflood and ephemeral stream channel deposits. Palaeocurrents are directed eastwards (Alexander-Marrack \& Friend, 1976; Olsen, 1993). Collectively the dominantly red deposits are interpreted in terms of braided channels and sheetfloods grading down-stream into terminal flood basins characterized by ephemeral stream processes.

The changing nature of alluvial systems, together with the colour changes in the resulting deposits, is interpreted as controlled by climatic changes (Olsen, 1993). During relatively humid periods the green, grey and black deposits were laid down, whereas red sediments were deposited during presumably relatively arid conditions. The thick successions of green and grey 
sediments locally exposed indicate that humid conditions prevailed for prolonged periods during certain time intervals.

Boundaries. The formation is transitional to the underlying Solstrand Formation on Strindberg Land, western Ymer $\emptyset$ and Hudson Land. Here the lower boundary is taken at the base of the first green unit in the Ankerbjergselv Formation (Fig. 24). At Ramsay Bjerg the lower boundary is taken at the base of the first greenish grey siltstone overlying the pale grey coarse-medium sandstones and associated red siltstones of the Solstrand Formation. In the Kap Franklin area the boundary is placed at the base of the first black shale or associated grey siltstone or very fine-grained sandstone bed conformably overlying the grey pebbly sandstones of the Solstrand Formation.
The upper boundary is defined by an abrupt change from red and green sandstones and siltstones to green, grey, red or white sandstones or conglomerates of the Kap Kolthoff Group or volcanics (Alexander-Marrack \& Friend, 1976) of the same group. In general the upper boundary is unconformable.

Distribution. In the study area the formation is exposed in Hudson Land, Gauss Halvø, southern Strindberg Land, western Ymer $\emptyset$ and western Geographical Society $\varnothing$ (Figs 8-10; Larsen ,1990a).

Geological age. The presence of the small crossopterygian Gyroptychins groenlandicus, found in the Kap Franklin area (Alexander-Marrack \& Friend, 1976), suggests an upper Middle Devonian (Givetian) age (Jarvik, 1950).

\section{Kap Kolthoff Group}

History and general remarks. Sedimentary rocks of this group were investigated in the entire study area except for the outcrops around Kap Franklin. The group corresponds in general to the 'Kap Kolthoff Series' of Bütler $(1935,1959)$, the 'Cape Kolthoff Series' of Koch \& Haller (1971) and the Kap Kolthoff Supergroup of Alexander-Marrack \& Friend (1976), Yeats \& Friend (1978) and Friend et al. (1983) (Figs 3, 4). In detail, however, the boundary delimitation is different at several localities which will be specified below. One major difference from the previously defined Kap Kolthoff Supergroup is that Yeats \& Friend (1978) included the basal Devonian deposits, i.e. conglomerates and alternating green and red sandstones, in the western outcrop area (Strindberg Land, Ymer $\emptyset$, Ella $\emptyset$ ) in the Kap Kolthoff Supergroup. These sediments are now included in the Vilddal Group.

Yeats \& Friend (1978) assigned a supergroup rank to the lithostratigraphic unit, mainly because of its great thickness and varied nature. Although these authors made a subdivision into named constituent formations in their study area (the western part of the Devonian outcrop area) the unit was not consequently subdivided into formations in the central and eastern part of the outcrop area by Nicholson \& Friend (1976) and Alexander-Marrack \& Friend (1976). The subdivision of the unit into groups and formations by Yeats \& Friend (1978) is commonly geographical in nature and inconve- nient both from mapping and sedimentological points of view. It is therefore proposed to reduce the lithostratigraphic unit to group status. The former constituent groups and formations are suggested abandoned or redefined. They include the Hjelmbjergene Group, the Upper Rødebjerg Formation, the Lower Rødebjerg Formation, the Sederholm Bjerg Grey Sandstone Formation, the Sofia Sund Formation and the Langbjerg Red Sandstone Formation (Fig. 5).

The Giesecke Bjerge Group (Alexander-Marrack \& Friend, 1976) is exposed in the Kap Franklin area. These rocks, subdivided into the Kap Franklin Formation and Randbøl Formation (equivalent to Bütler's (1954) 'Kap Franklin Serien' and 'Randböl Serien'), collectively were assigned to the Kap Kolthoff Supergroup, and are probably equivalent to what is now defined as the Kap Kolthoff Group. The constituent formations of the former Giesecke Bjerge Group are therefore maintained, forming parts of the Kap Kolthoff Group. The Giesecke Bjerge Group is abandoned as a lithostratigraphic name (Fig. 5).

In the eastern part of the area the group is characterized by several local angular unconformities. The unconformities lose their angular identities southwestwards towards the central part of the outcrop area.

Name. From the northwestern cape of Gauss Halvø (Fig. 6). 
Type area. Gauss Halvø and Ymer $\emptyset$ (Fig. 6).

Thickness. The maximum preserved thickness of the group has been measured in western Gunnar Anderson Land, where more than $2700 \mathrm{~m}$ of sediments onlap the Vilddal Group and pre-Devonian rocks. In Hudson Land the preserved thickness is less, around $2000 \mathrm{~m}$ in the Högbom Bjerg - Ankerbjerg area.

Dominant lithology. The group is mainly composed of medium and coarse-grained sandstones (Figs 28-31). Locally, in the marginal parts of the outcrop area conglomerates occur. Siltstones and shales are rarely found. The sedimentary rocks are yellowish white, green, grey, and red. Commonly carbonate cement occurs in the sandstones. The rocks usually disintegrate due to weathering processes, and are developed as scree. Volcanics, both basic and acid, are common in the group.

Depositional environments and palaeocurrents. Most of this group was deposited by extensive coalescing sandy braidplains (Olsen, 1993). Locally terminal fans developed. Apex of both braidplain fans and terminal fans was probably commonly composed of pebbly rivers though these proximal deposits are rarely preserved. Locally ergs developed and rarely lakes occurred. The palaeocurrent pattern is generally symmetrical, exhibiting southeastward sediment transport in the western part of the outcrop area and southwestward transport in the eastern part of the area. In the aeolian parts of the group palaeowinds are mainly directed northwestwards.

Boundaries. In Strindberg Land and parts of western Ymer $\emptyset$ the lower boundary is defined by the abrupt and unconformable change from alternating green and red sandstones of the underlying Ankerbjergselv Formation (Vilddal Group) to onlapping green sandstones of the Kap Kolthoff Group. In some parts of western Ymer $\varnothing$ the group rests unconformably on Precambrian to Cambrian-Ordovician sediments (Fig. 6). In the central part of the outcrop area the base of the group is not exposed except in western Moskusoksefjord ('Moskusoksefjord Inlier'). Here it is composed of red and green sandstones resting unconformably with onlap on conglomerates of the Genvejsdalen Member (Kap Bull Formation, Vilddal Group) and on crystalline rocks of the 'inlier' (Figs 8, 20). The basal part is marked by a conglomerate on the western side of the 'inlier' and by sandstones on the eastern side. In the north near the mountain Snehvide red conglomerates of the group (Snehvide Formation) unconformably rest on Precambrian rocks of the Eleonore Bay Group and on red conglomerates of the Solstrand Formation (Fig. 55).

In eastern Hudson Land and central Gauss Halvø, the lower boundary is unconformable and the group rests on different parts of the Vilddal Group (Fig. 8). Here the basal part is usually composed of sandstones or conglomerates (the Sofia Sund Formation and - in the Ankerbjergselv area, the Vergys Formation). In the Kap Franklin area the basal rocks are volcanics (Alexander-Marrack \& Friend, 1976).

The upper boundary is defined by an upward change from grey or yellowish white sandstones of the Kap Kolthoff Group to red and green banded siltstones with subordinate sandstones of the Kap Graah Group (Zoologdalen Formation) on Strindberg Land and western Gunnar Andersson Land (west of Zoologdalen; Fig. 61). In western Hudson Land (Rødtop), western and central Gauss Halvø and eastern Gunnar Andersson Land (east of Zoologdalen) the upper boundary is defined by a change from mainly recessive grey or white pebbly sandstones and rare red pebbly sandstones of the Kap Kolthoff Group to resistant red (locally grey) pebble free sandstones of the Kap Graah Group (Udkiggen Formation). At Högbom Bjerg the upper boundary is characterized by an upward change from red pebbly sandstones of the Kap Kolthoff Group to red pebbly sandstones and conglomerates of the Rødsten Formation or red pebble free sandstones of the Udkiggen Formation (Kap Graah Group; Fig. 61). From a distance this contact is difficult to distinguish precisely because the rocks on both sides of the contact are red and resistant. All contacts to the Kap Graah Group are conformable. In Hjelmbjergene and east of Sederholm Bjerg in eastern Gauss Halvø red and green sandstones of the Kap Kolthoff Group are unconformably overlain by red sandstones and conglomerates of the Agda Dal Formation (Celsius Bjerg Group) (Figs 61, 85). At central Celsius Bjerg on Ymer $\emptyset$ red sandstones of the group are overlain by green-spotted red sandstones of the Agda Dal Formation probably separated by a parallel unconformity (Fig. 85). On eastern Celsius Bjerg near Kap Humboldt the upper boundary is defined by a non-angular unconformable contact between yellowish white sandstones of the Kap Kolthoff Group and red siltstones and very fine-grained sandstones of the overlying Aina Dal Formation (Celsius Bjerg Group) (Fig. 85).

In the previous section it was noted that the basal Devonian conglomerates and sandstones in the western outcrop area are now included in the Vilddal Group in contrast to Yeats \& Friend (1978), who included these deposits in their 'Kap Kolthoff Supergroup'. In the following further deviations from earlier work in other areas are discussed. 


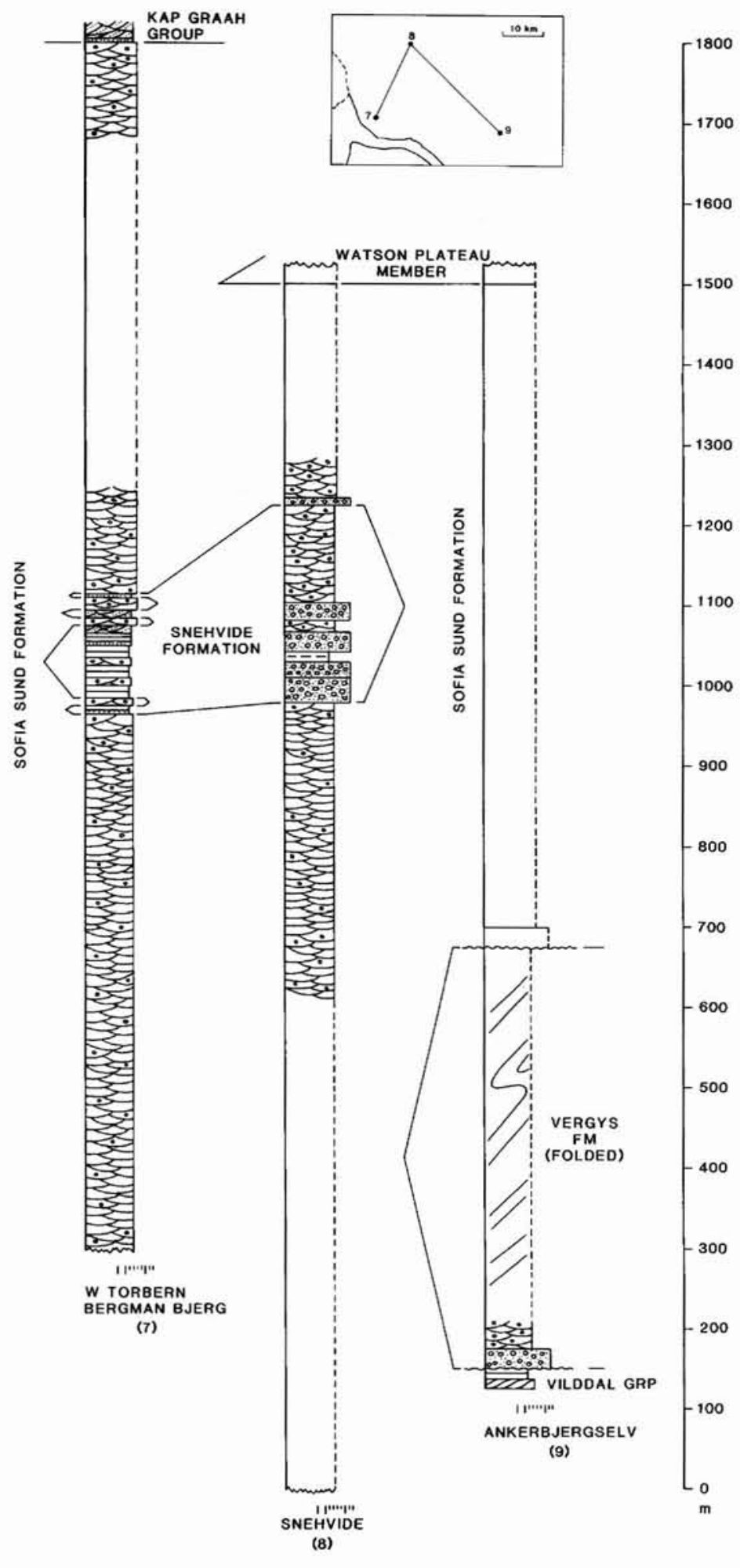

Fig. 28. Generalized sections from the Kap Kolthoff Group in Hudson Land. For locations see also Figs 45,55 . Section 8 is the type section of the Snehvide Formation. Section 9 is the type section of the Vergys Formation. Legend: Plate 2.
In Moskusokselandet Bütler (1959, p. 68) and Nicholson \& Friend (1976, p. 77 and pl. 15) defined the upper boundary of the group at the angular unconformity exposed on Högbom Bjerg and the continuation of this 


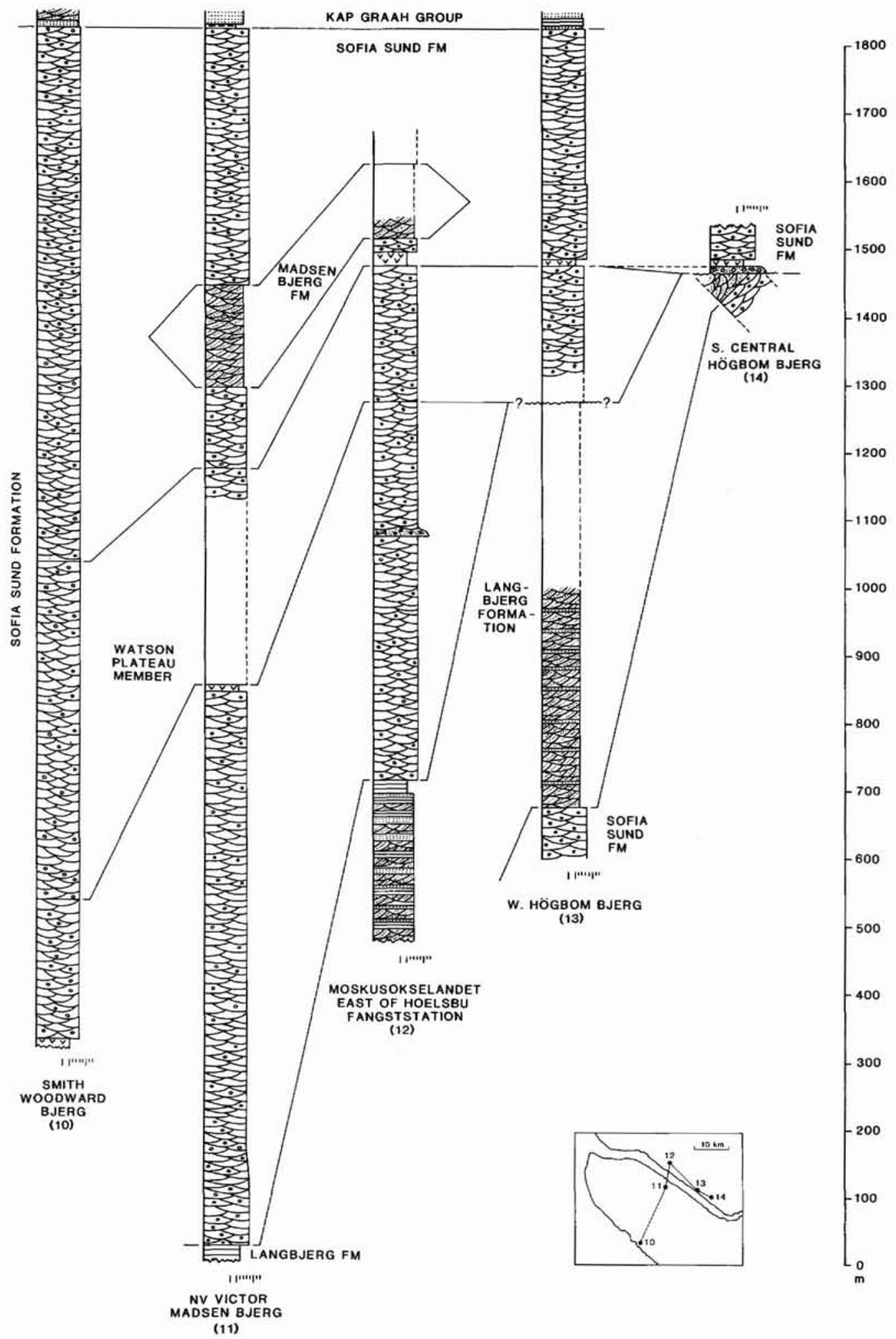

Fig. 29. Generalized sections from the Kap Kolthoff Group in Gauss Halvø and Moskusokselandet. For locations see also Figs $38,45$. Section 10 is the principal reference section for the Sofia Sund Formation and type section for the Watson Plateau Member. Section 11 is the type section for the Madsen Bjerg Formation. Section 13 is type section for the Langbjerg Formation. Legend: Plate 2. 


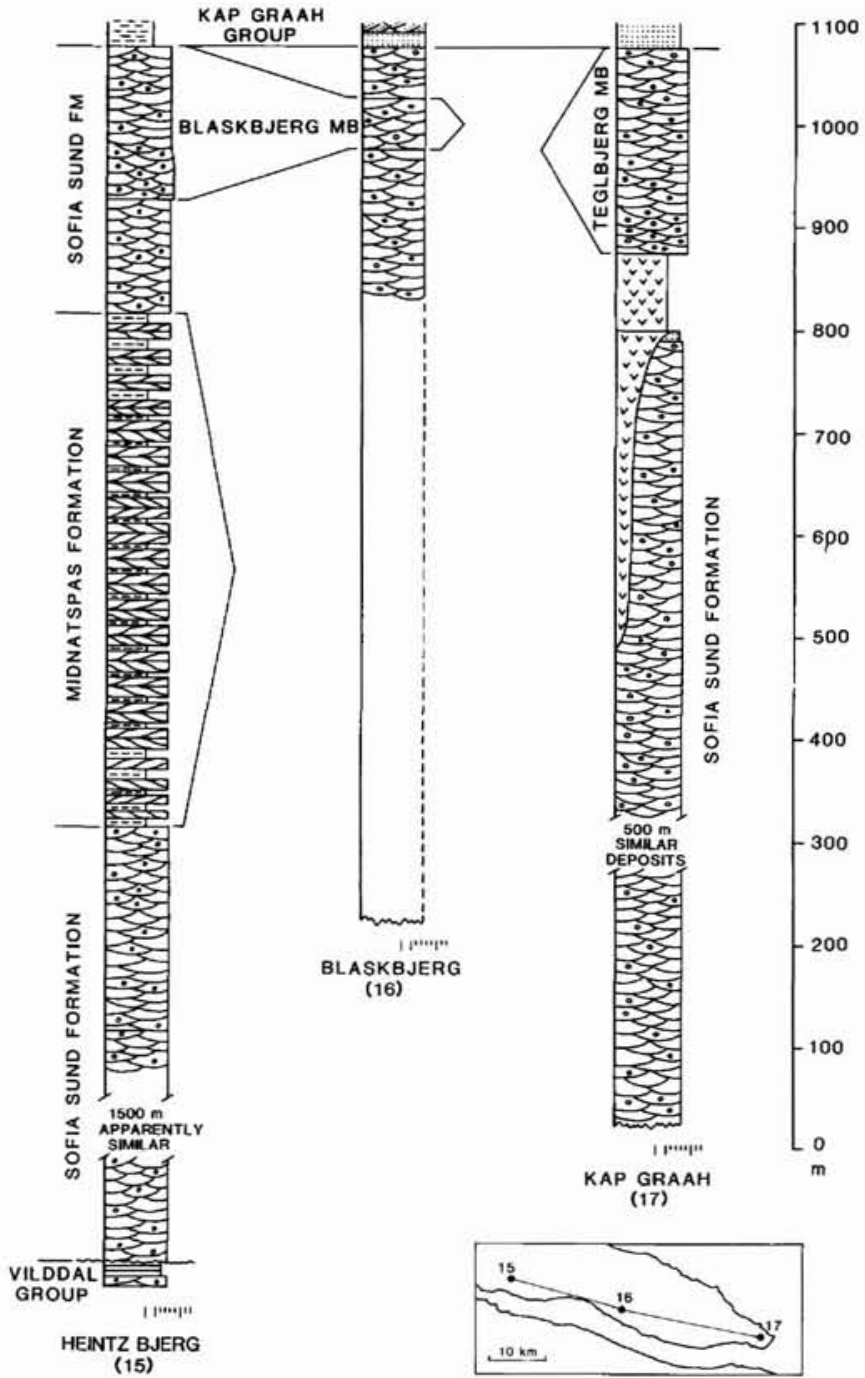

Fig. 30. Generalized sections from the Kap Kolthoff Group in Gunnar Andersson Land. For locations see also Figs 40,42 . Section 15 is type section for the Sofia Sund Formation, Midnatspas Formation and Blaskbjerg Member (Sofia Sund Formation). The type section for the Teglbjerg Member (Sofia Sund Formation) is section 17. Legend: Plate 2.

surface towards the northwest, where the angular unconformity is absent (see also Larsen, 1990a, d). The conglomerate and succeeding sandstones above this surface show close affinities to other parts of the Kap Kolthoff Group. From a sedimentological point of view these fluvial rocks cannot correlate with the basal aeolian rocks of the Kap Graah Group in neighbouring areas, as now defined by us (see later). Accordingly the upper boundary of the Kap Kolthoff Group is now placed higher in the succession on Högbom Bjerg, as defined previously, and Kap Graah Group sediments are absent in Moskusokselandet between Högbom Bjerg in east and Rødtop/Torbern Bergman Bjerg in west (Figs 6, 28, 29, 38).

At Smith Woodward Bjerg on Gauss Halvø (Fig. 38), Nicholson \& Friend (1976, p. 67) placed the upper boundary at an upward transition from grey pebbly sandstones to red pebbly sandstones, all characterized by the same general facies assemblage. These sediments and a succeeding grey unit of similar facies types are now included in the Kap Kolthoff Group (Table 1, Figs 29,39 ). The overlying red resistant pebble free sandstones (Fig. 32) now defined as the basal parts of the Kap Graah Group (Udkiggen Formation) correlates with a similar unit in western Gauss Halvø recognized as the basal part of the Kap Graah Group by both Nicholson \& Friend (1976, p. 71) and the present authors (Fig. 61).

In Gunnar Andersson Land at Kap Graah the upper boundary is taken at the base of the red pebble free sandstone, the Udkiggen Formation of the Kap Graah Group overlying a red pebbly sandstone unit (Figs 30, 
$43,61,63)$. This is in contrast to Nicholson \& Friend (1976, fig. 15), who included the red pebbly sandstone (their 'lower pebbly sandstone division') in the Kap Graah Group as well as an underlying volcanic unit (their 'volcanic division'). However, the pebble free (aeolian) sandstone unit seems to correlate with the basal (aeolian) deposits of the Kap Graah Group defined at Rødsten, western Gauss Halv $\varnothing$ and Rødtop by Nicholson \& Friend (1976) and elsewhere by the present authors (Fig. 61). The red pebbly (fluvial) sandstone unit, underlying the aeolian sandstone at Kap Graah is similar to the Sofia Sund Formation of the Kap Kolthoff Group at other localities and, accordingly, is included in the Kap Kolthoff Group by us (Table 1).

At southwestern Celsius Bjerg (Figs 85, 87) the upper boundary of the group was taken at the contact between grey pebbly sandstones and overlying red pebbly sandstones, supposed to be part of Kap Graah Group, by Nicholson \& Friend $(1976$, figs 22, 24). These red sandstones are, however, composed of the same facies as the underlying grey sandstones and seem to correlate with the uppermost red sandstones of the Kap Kolthoff Group in eastern Gunnar Andersson Land. Accordingly, the red sandstone unit is included in the Kap Kolthoff Group, and the upper boundary is now defined by the contact to the overlying green-spotted red sandstones of the Agda Dal Formation, Celsius Bjerg Group (Table 1).

On the geological map of Koch \& Haller (1971) all sedimentary rocks east of the prominent fault on eastern Celsius Bjerg are assigned to the Carboniferous. The present investigations show, however, that the majority of these rocks are Devonian. The Kap Kolthoff Group forms the lowermost part of this succession (Larsen et al., 1989; Larsen, 1990a).

Distribution. The group crops out in Hudson Land, Gauss Halv $\varnothing$, southern Strindberg Land, Ymer $\emptyset$, Geographical Society $\varnothing$, and Traill $\varnothing$ (Fig. 6), see also Larsen (1990a).

Geological age. Bothriolepis jarviki has been found in the upper part of the group from a number of localities in the study area (Yeats \& Friend, 1978). According to Jarvik (1961, p. 198) this fauna is early Famennian (Late Devonian). Fish remains in the Randbøl Series, supposed equivalent to the lower part of the group, indicate

Fig. 31. Generalized section from the Kap Kolthoff Group at Rødebjerg, southern Ymer $\emptyset$. For location see also Fig. 50. The section is type section for the Barnabas Dal Formation and the Rødebjerg Formation. Legend: Plate 2.

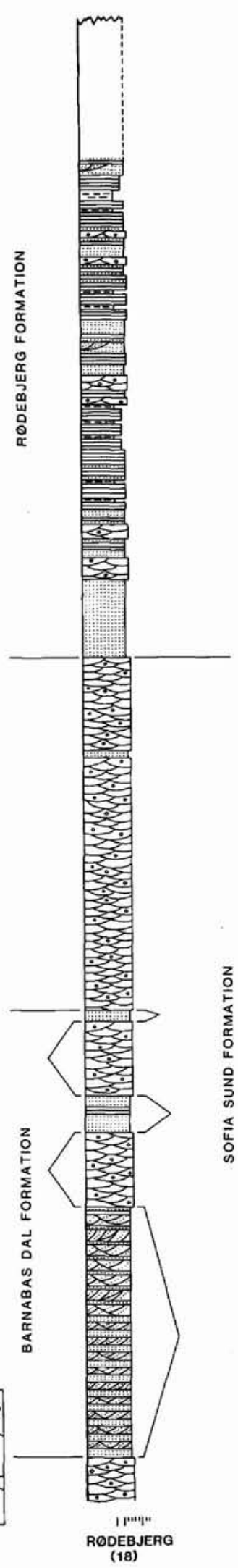


Table 1. Comparison with Nicholson \& Friend (1976) of upper boundary delimitation for the Kap Kolthoff Group at three localities

\begin{tabular}{|c|c|c|c|c|c|c|c|c|c|c|}
\hline \multicolumn{4}{|c|}{ SMITH WOODWARD BJERG } & \multicolumn{4}{|c|}{ KAP GRAAH AREA } & \multicolumn{3}{|c|}{ SOUTHWESTERN CELSIUS BJERG } \\
\hline $\begin{array}{c}\text { Nicholson \& } \\
\text { Friend (1976) }\end{array}$ & $\begin{array}{c}\text { Sedimentary } \\
\text { succession }\end{array}$ & \multicolumn{2}{|c|}{ This paper } & $\begin{array}{l}\text { Nicholson \& } \\
\text { Friend (1976) }\end{array}$ & $\begin{array}{l}\text { Sedimentary } \\
\text { succession }\end{array}$ & \multicolumn{2}{|c|}{ This paper } & $\begin{array}{l}\text { Nicholson \& } \\
\text { Friend (1976) }\end{array}$ & $\begin{array}{l}\text { Sedimentary } \\
\text { succession }\end{array}$ & This paper \\
\hline \multirow{3}{*}{$\begin{array}{l}\text { KAP } \\
\text { GRAAH } \\
\text { GROUP }\end{array}$} & $\begin{array}{l}\text { Red pebble free } \\
\text { sandstones } \\
\text { (aeolian) }\end{array}$ & \multicolumn{2}{|c|}{$\begin{array}{l}\text { KAP } \\
\text { GRAAH } \\
\text { GROUP }\end{array}$} & \multirow{2}{*}{$\begin{array}{l}\text { KAP } \\
\text { GRAAH } \\
\text { GROUP }\end{array}$} & $\begin{array}{l}\text { Red pebble free } \\
\text { sandstones } \\
\text { (aeolian) }\end{array}$ & \multicolumn{2}{|c|}{$\begin{array}{l}\text { KAP } \\
\text { GRAAH } \\
\text { GROUP }\end{array}$} & \multirow{4}{*}{$\begin{array}{l}\text { KAP } \\
\text { GRAAH } \\
\text { GROUP }\end{array}$} & $\begin{array}{l}\text { Green-spotted } \\
\text { red sandstone } \\
\text { with few peb- } \\
\text { bles (fluvial) }\end{array}$ & $\begin{array}{l}\text { CELSIUS } \\
\text { BJERG } \\
\text { GROUP }\end{array}$ \\
\hline & $\begin{array}{l}\text { Grey pebbly } \\
\text { sandstones } \\
\text { (fluvial; } \\
\text { c. } 900 \mathrm{~m} \text { ) }\end{array}$ & & \multirow{4}{*}{$\begin{array}{c}\text { KAP } \\
\text { KOLT- } \\
\text { HOFF } \\
\text { GROUP } \\
\\
\text { Sofia } \\
\text { Sund } \\
\text { Fm }\end{array}$} & & $\begin{array}{l}\text { Red pebbly } \\
\text { sandstones } \\
\text { (fluvial; } \\
\text { c. } 200 \mathrm{~m} \text { ) }\end{array}$ & $\begin{array}{c}\text { Tegl- } \\
\text { bjerg } \\
\mathrm{Mb}\end{array}$ & $\begin{array}{c}\text { KAP } \\
\text { KOLT- }\end{array}$ & & $\begin{array}{l}\text { Red pebbly } \\
\text { sandstones } \\
\text { (fluvial; } \\
\text { c. } 600 \mathrm{~m} \text { ) }\end{array}$ & \\
\hline & $\begin{array}{l}\text { Red pebbly } \\
\text { sandstones } \\
\text { (fluvial; } \\
\text { c. } 500 \mathrm{~m} \text { ) }\end{array}$ & $\begin{array}{c}\text { Watson } \\
\text { Plateau } \\
\mathrm{Mb}\end{array}$ & & \multirow{3}{*}{$\begin{array}{c}\text { KAP } \\
\text { KOLTHOFF } \\
\text { SUPERGROUP }\end{array}$} & $\begin{array}{c}\text { Volcanics } \\
(75-350 \mathrm{~m})\end{array}$ & & $\begin{array}{l}\text { HOFF } \\
\text { GROUP } \\
\text { Sofia }\end{array}$ & & $\begin{array}{c}\text { Basalt } \\
(c .5 \mathrm{~m})\end{array}$ & $\begin{array}{c}\text { KAP } \\
\text { KOLTHOFF } \\
\text { GROUP }\end{array}$ \\
\hline \multirow{2}{*}{$\begin{array}{c}\text { KAP } \\
\text { KOLTHOFF } \\
\text { SUPERGROUP }\end{array}$} & \multirow{2}{*}{$\begin{array}{l}\text { Grey pebbly } \\
\text { sandstones } \\
\text { (fluvial) }\end{array}$} & & & & \multirow{2}{*}{$\begin{array}{l}\text { Grey pebbly } \\
\text { sandstones } \\
\text { (fluvial) }\end{array}$} & & Fm & & $\begin{array}{l}\text { Red pebbly } \\
\text { sandstones } \\
\text { (fluvial; } \\
\text { c. } 30 \mathrm{~m} \text { ) }\end{array}$ & $\begin{array}{l}\text { Sund } \\
\text { Fm }\end{array}$ \\
\hline & & & & & & & & $\begin{array}{c}\text { KAP } \\
\text { KOLTHOFF } \\
\text { SUPERGROUP }\end{array}$ & $\begin{array}{l}\text { Grey pebbly } \\
\text { sandstones } \\
\text { (fluvial) }\end{array}$ & \\
\hline
\end{tabular}


Fig. 32. Western part of the mountain Smith Woodward Bjerg, Gauss Halvø, facing Kejser Franz Joseph Fjord. The mountain ridge is type section 10 (Fig. 29) for the Watson Plateau Member (WP) and principal reference section for the Sofia Sund Formation (SS). It is type and reference section 20 (Fig. 62) for several formations of the Kap Graah Group (KG GRP). Notice the dark (red) wedge in the upper part of the Sofia Sund Formation, representing a braidplain segment. Another. regionally mappable, segment is represented by the Watson Plateau Member, the base of which was defined as the base of the Kap Graah Group by Nicholson \& Friend (1976). Highest point of the mountain face

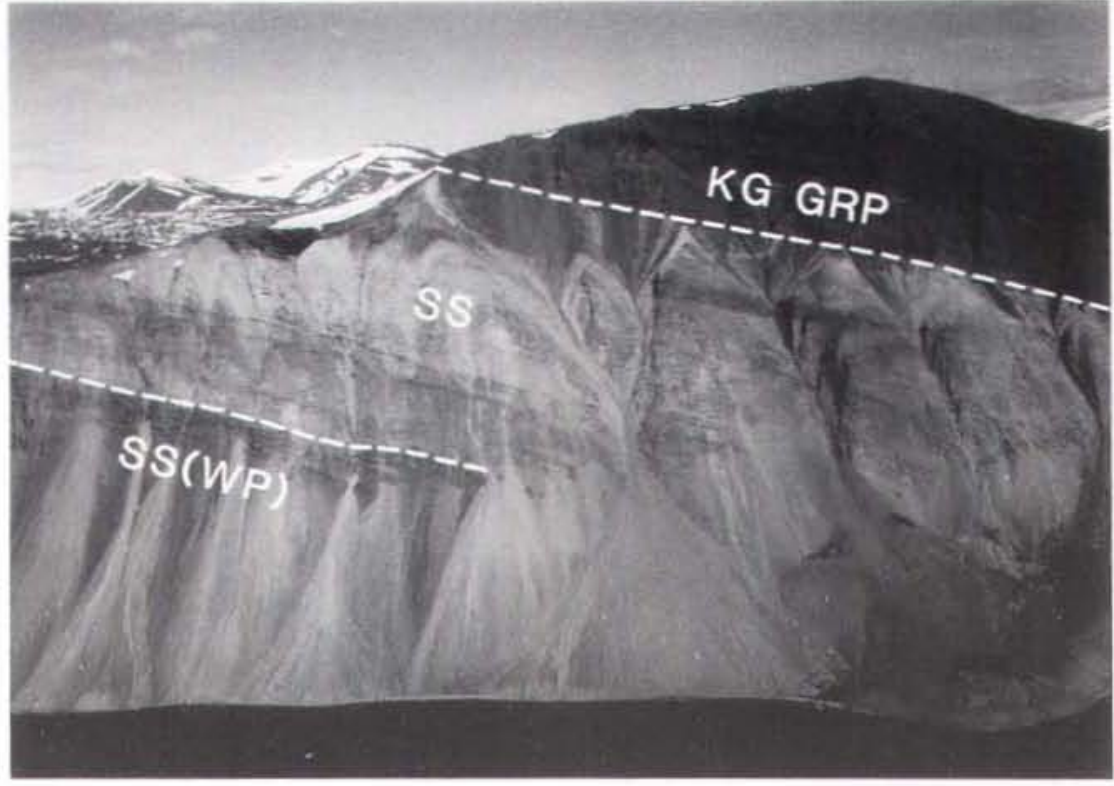
shown is $c .950 \mathrm{~m}$.

a Middle Devonian probably Givetian age (Būtler, 1954; Jarvik, 1950; Alexander-Marrack \& Friend. 1976). In the underlying Vilddal Group Givetian fish faunas (Jarvik, 1950) and floras (Allen, 1972) have been identified. Accordingly the Kap Kolthoff Group probably spans in age from Givetian through Frasnian to early Famennian.

Subdivisions. The group is subdivided into eight formations. These include Sofia Sund, Vergys, Langbjerg, Barnabas Dal, Snehvide, Rødebjerg, Madsen Bjerg and Midnatspas Formations (Plate 1). The Sofia Sund Formation is volumetrically the most important component formation and within this formation all other formations occur as large-scale wedges or lenses, up to several hundred metres thick (Figs 28-31).

The mainly green and greenish grey sandstones of the Vergys Formation and lower part of the Sofia Sund Formation may informally be termed the lower Kap Kolthoff Group, whereas the remaining part of the group with very few green and greenish grey sandstones may be termed the upper Kap Kolthoff Group. Further investigations are, however, needed to outline if these sedimentary rocks form coherent units, which should be formally defined.

\section{Sofia Sund Formation}

History. Yeats \& Friend (1978) and Friend et al. (1983) defined this formation as a grey sandstone unit with minor red sandstones. According to these authors the formation is transitional to their underlying 'Upper Rødebjerg Formation', now redefined and renamed the Rødebjerg Formation (see below) and transitional to the overlying Kap Graah Group. The formation is here revised to include the entire Kap Kolthoff Group in the study area except seven local, sedimentologically distinct and mappable formations, forming large-scale wedges and lenses within the Sofia Sund Formation. The formation was indicated on the map of Koch \& Haller (1971) partly as 'Middle Devonian', partly as 'Cape Kolthoff Series' and partly as 'Cape Graah Series'.

Name. After Sofia Sund, between Ymer $\varnothing$ and Geographical Society $\varnothing$ (Fig. 6).

Type and reference sections. From the description by Friend et al. (1983, p. 14) the location of the type section is uncertain. Therefore, the mountain Heintz Bjerg west of Zoologdalen in Gunnar Andersson Land is defined as a new type section (section 15, Figs 30, 40, 41). Here the most complete section is exposed. The mountain is, however, difficult of access and therefore a principal reference section is chosen on NW Smith Woodward Bjerg (section 10, Figs 29, 32, 38) where the formation is also characteristically developed and easily accessible. Reference sections are located at numerous localities on Ymer $\emptyset$, Gauss Halvø and in Hudson Land (sections 7-18, Figs 28-31, 38, 40, 42, 45, 50, 55). Detailed reference sections are northwest of Paralleldal at 


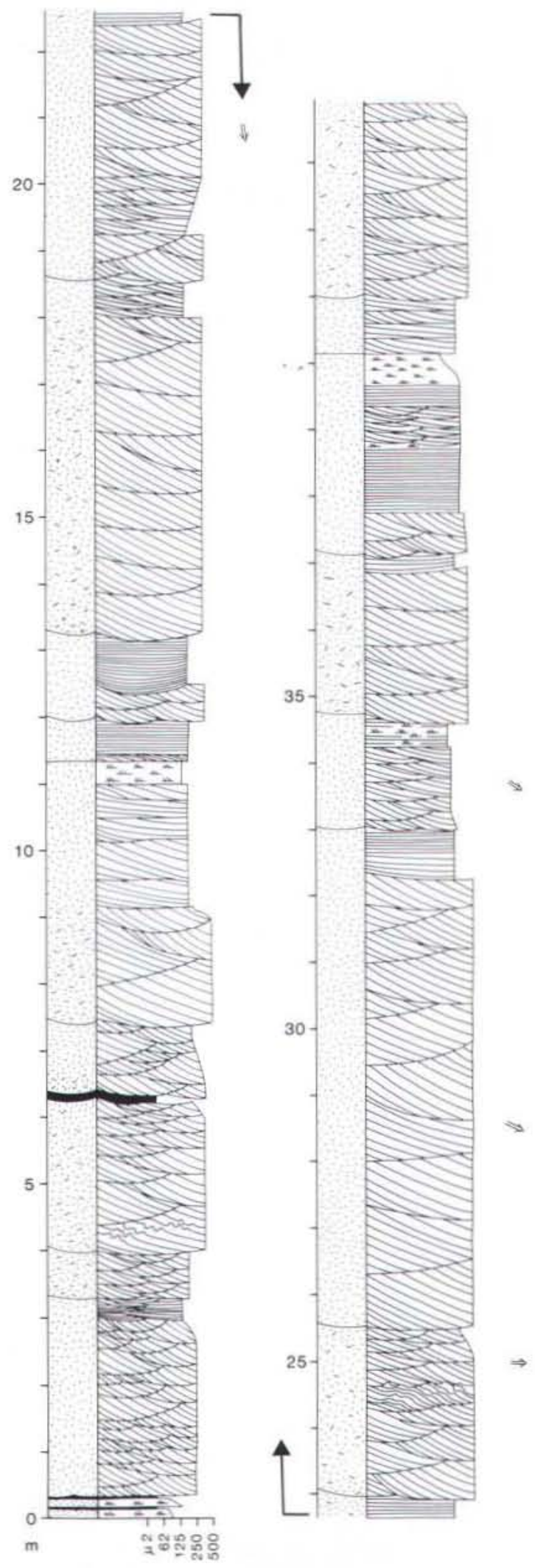

Kejser Franz Joseph Fjord (Fig. 33), Damesten (Fig. 34), the north side of Udkiggen (Fig. 35), Kap Graah (Fig. 36) and Rødebjerg (Fig. 37).

Thickness. The maximum preserved thickness of the formation has been measured in western Gunnar Andersson Land where it exceeds $2700 \mathrm{~m}$, including a wedge of the Midnatspas Formation (section 15, Fig. 30).

Lithology and sedimentary structures. The formation is characterized by medium and coarse-grained trough cross-bedded sandstones. Subordinate facies are parallel laminated, cross-bedded and rarely cross-laminated finer-grained sandstones. Siltstones occur as intra-clasts and very rare $\mathrm{cm}$-thick beds. The sandstones are usually arranged in fining upward units, a few metres thick. Small rounded pebbles are common, although usually forming less than $2 \%$ of the rocks. Wedge shaped conglomerate bodies, a few tens of metres thick. occur locally, usually associated with unconformity surfaces. The sediments are green, grey, white, yellowish white and red. The exposed lower few hundred metres of the formation are green or greenish grey in the main part of the outcrop area, including the type section. The remaining part of the formation is dominated by white and yellowish white sandstones with important units of red sandstone and minor grey sandstone units. Along the margins of the outcrop area (east, west and north) the individual coloured units are commonly distinct and mappable. Towards the central part of the area the units are usually less distinct, either interdigitating or mixed. Volcanics, both basic and acid, are common in the formation.

Depositional environments and palaeocurrents. The formation represents a huge, sandy braidplain composed of fan shaped braidplain segments (Olsen, 1993). The extent of individual braidplain segments were in the order of tens of kilometres. Towards the centre of the basin the segments lost their identity and formed an extensive braided riverplain, draining longitudinally southwards. Palaeocurrents along the margins of the basin are directed towards the basin axis where they

Fig. 33. Facies log from the Sofia Sund Formation, exhibiting the typical development of the formation; dominance of medium-grained, trough cross-bedded sandstones, arranged in fining upward units a few metres thick. The log was measured c. 1200 below the top of the formation at the coastal outcrop in Gauss Halvø along Kejser Franz Joseph Fjord, c. 2.5 km NW of the Paralleldal delta. Legend: Plate 2. 
gradually turn south, parallel to the axis. The local, wedge shaped conglomerates represent small alluvial fans or high gradient alluvial plains developed in the proximal parts of braidplain segments.

Boundaries. The formation forms the base and top of the Kap Kolthoff Group in the entire study area, except at three localities mentioned below. For description of the lower and upper boundary conditions in general the reader is referred to the description of the Kap Kolthoff Group. The three exceptions are in the area of Snehvide where the Snehvide Formation forms the base, in the Ankerbjergselv area, where the Vergys Formation forms the base, and in the Kap Franklin area. See description of boundary conditions between the Sofia Sund Formation and the Snehvide and Vergys Formations in the sections concerning these latter formations. At Kap Franklin (Fig. 7) volcanics form the base of the group (Alexander-Marrack \& Friend, 1976) and the Sofia Sund Formation is absent (see also Larsen, 1990a). Several large-scale wedges or lenses of other formations occur within the Sofia Sund Formation (Figs 28-31). The boundary conditions between these units and the Sofia Sund Formation are described in the following sections under the respective formations.

Distribution. The Sofia Sund Formation crops out in Ole Rømer Land, Hudson Land, Gauss Halvø, southern Strindberg Land, Ymer $\emptyset$, Geographical Society $\emptyset$ and Traill $\varnothing$ (Fig. 6; Larsen 1990a).

Geological age. The formation extends from the base of the Kap Kolthoff Group to the top of it. Accordingly, the formation probably spans from Givetian through Frasnian to early Famennian in age as discussed elsewhere.

Subdivisions. The main part of the formation is not subdivided. However, in the uppermost part three members have been defined; the Watson Plateau Member, the Blaskbjerg Member and the Teglbjerg Member (Plate 1). These members are distinct and mappable due to the colour of the sediments, but are similar in sedimentary facies to the rest of the formation.

Fig. 34. Facies log from the Sofia Sund Formation at Damesten (Figs 6, 19), southernmost Strindberg Land illustrating the soft sediment deformations abounding at this locality. The logs are measured approximately $700 \mathrm{~m}$ below the contact to the Kap Graah Group. B exhibits the most typical grain size distribution at this locality, whereas A represents a slightly finergrained interval. Legend: Plate 2.

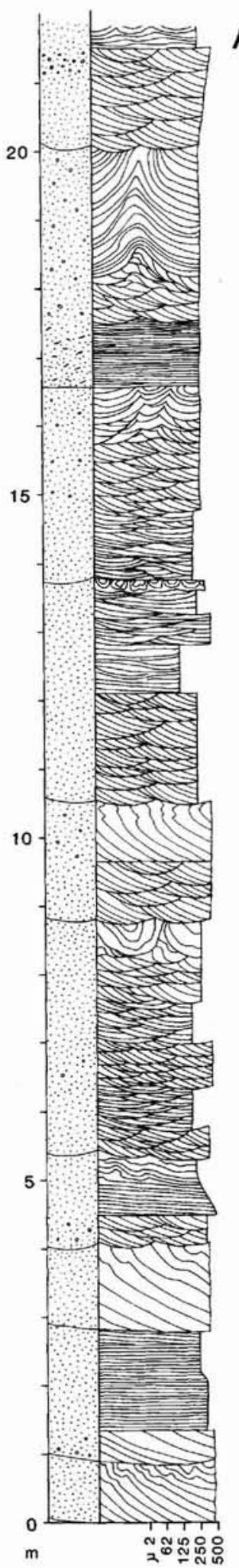

B

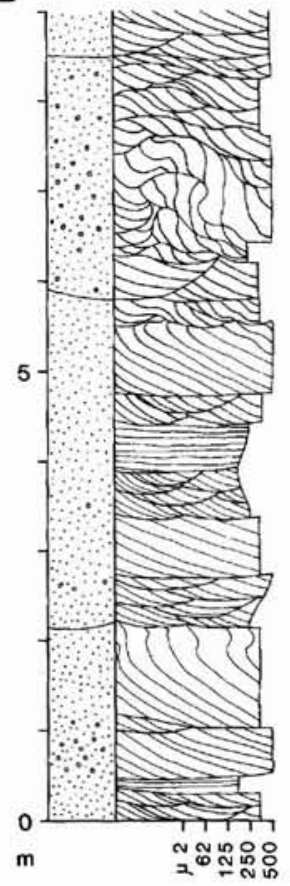




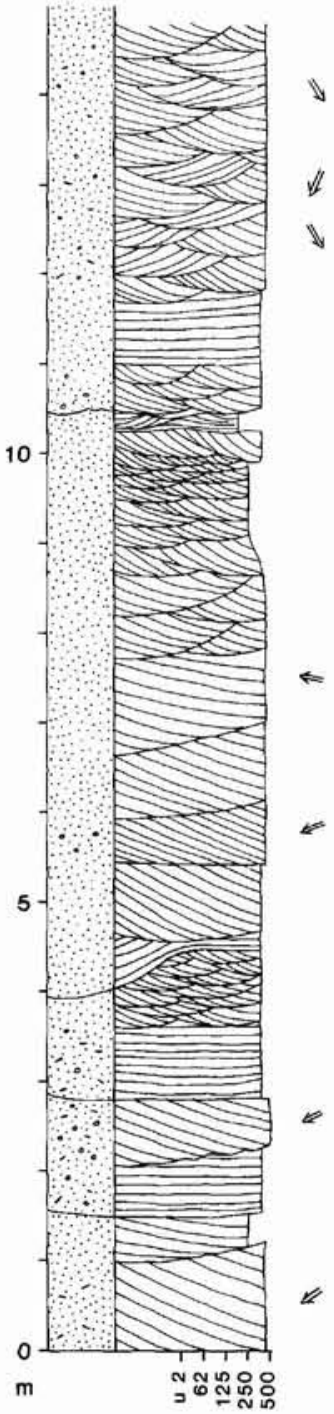

A

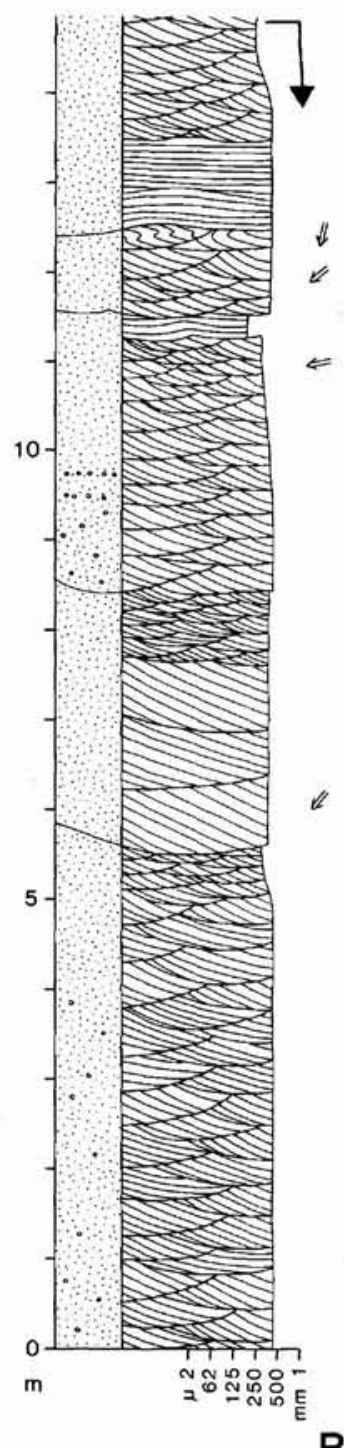

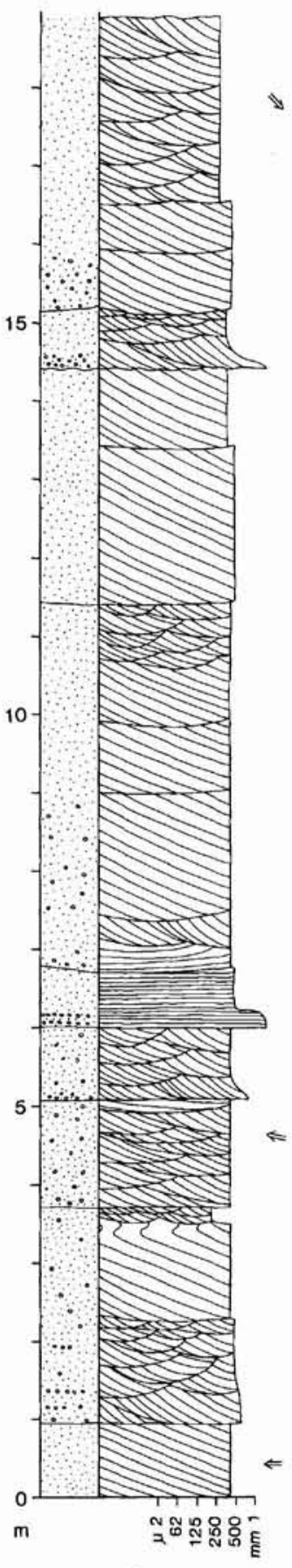

C

Fig. 35. Facies logs from the Sofia Sund Formation illustrating larger scale planar wedge-shaped and trough-shaped cross-sets associated with the typical medium-scale trough cross-bedding. The logs are measured c. $1600 \mathrm{~m}(\mathrm{~A}), c .1500 \mathrm{~m}(\mathrm{~B})$ and $c .1400 \mathrm{~m}$ (C) below the contact to the Kap Graah Group in the coastal exposure north of Udkiggen, Gunnar Andersson Land (section 27. Figs 61, 63). Legend: Plate 2. 


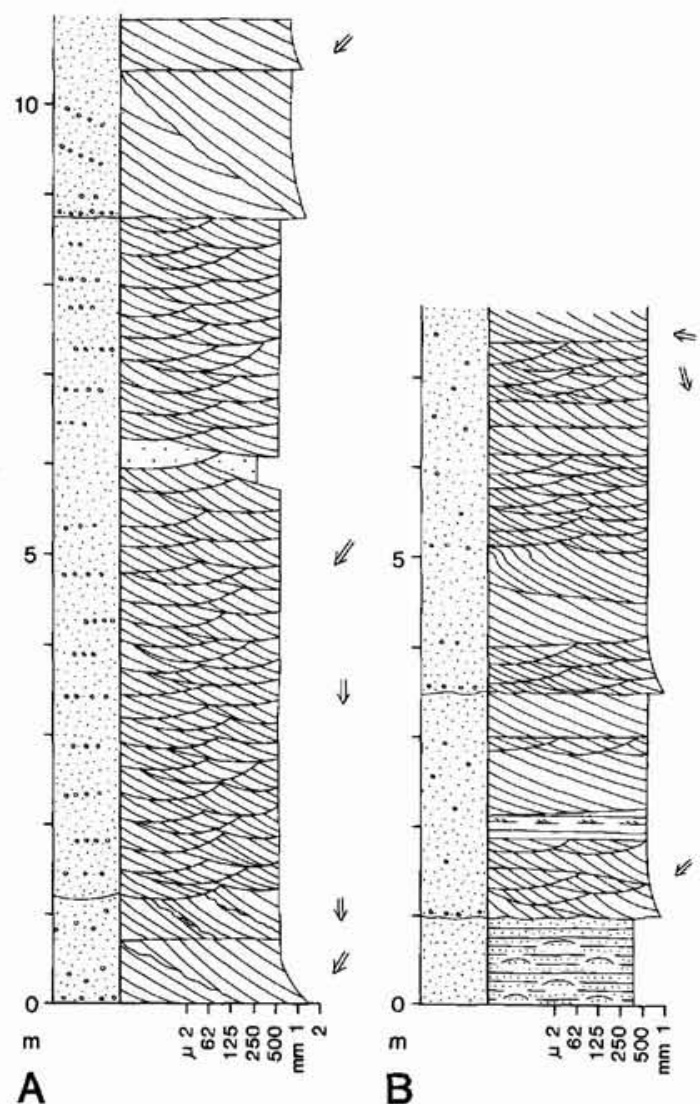

Fig. 36. Facies logs from the Sofia Sund Formation from reference section 17 at Kap Graah, c. $600 \mathrm{~m}$ (A) and c. $350 \mathrm{~m}$ (B) below the contact to the Kap Graah Group (Figs 30,42). The logs exhibit the typical development of the formation at this locality; dominance of pebbly, coarse-grained sandstones with trough cross-bedding. The top of a c. $5 \mathrm{~m}$ thick aeolian interval is observed in B. Larger scale planar wedge-shape cross-sets are observed in both sections. Legend: Plate 2 .

Fig. 37. Facies $\log$ from the lower Sofia Sund Formation at the mountain Rødebjerg, Ymer $\emptyset$. The log was measured in the green interval forming the lower few hundred metres exposed in the formation and located immediately east of the major thrust fault at Rødebjerg (see Fig. 50). Legend: Plate 2.
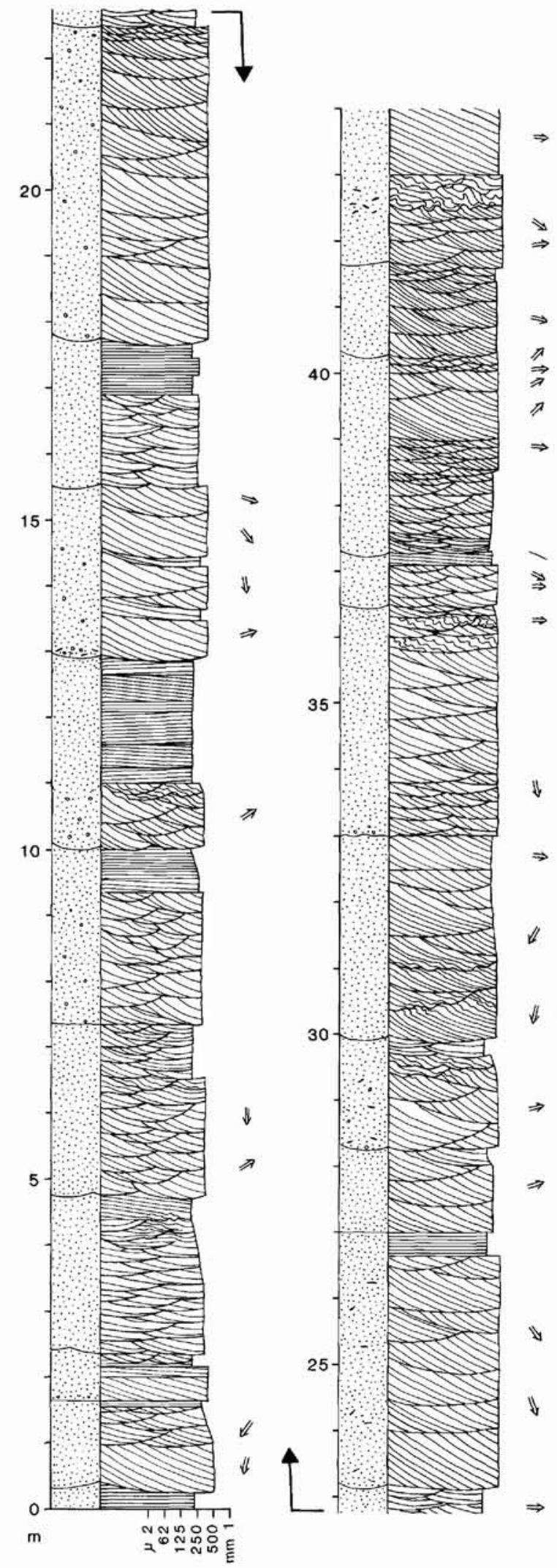


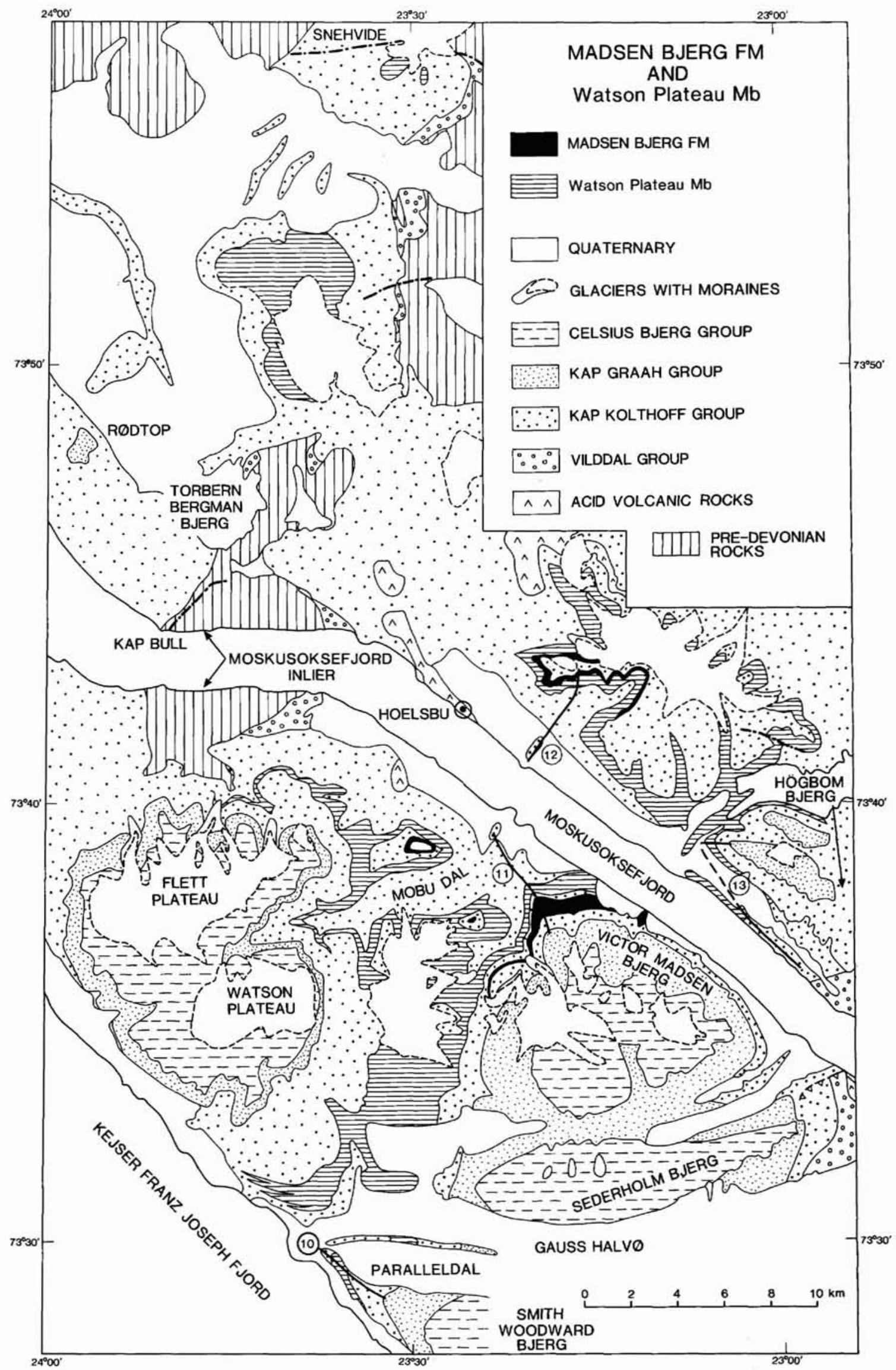


The lower few hundred metres of the formation is green or greenish grey in many outcrop areas (Fig. 37). It is uncertain if these rocks are correlatable and thus may be distinguished as a member. These rocks may informally be termed the lower Sofia Sund Formation.

\section{Watson Plateau Member \\ new member}

Name. After the plateau forming mountains, Watson Plateau, in western Gauss Halvo (Fig. 38).

Type and reference sections. The type section is western Smith Woodward Bjerg on south central Gauss Halvø (section 10, Figs 29, 38, 39). Reference sections are located to the northwest at Victor Madsen Bjerg (section 11, Figs 29, 38, 59), and in Moskusokselandet along Moskusoksefjord (sections 12, 13, Figs 29, 38).

Thickness. The member forms a large-scale wedge of the Sofia Sund Formation and attains a maximum thickness of $c .500 \mathrm{~m}$ at Smith Woodward Bjerg, south central Gauss Halvo (Fig. 39).

Lithology and sedimentary structures. The sediments consist of red medium to coarse-grained pebbly sandstones. Trough cross-bedding dominates, with set thickness generally in the range $8-30 \mathrm{~cm}$. Up to $10 \%$ very large-scale $(>50 \mathrm{~cm})$ trough to wedge-shaped cross-sets occur at some localities. Parallel laminated mediumgrained sandstone beds, $20-50 \mathrm{~cm}$ thick, occasionally separate $2-5 \mathrm{~m}$ thick cross-bedded units resulting in a distinct weathered-out bedding. The red colour is due to c. $20 \%$ feldspathic grains in the sandstones.

Depositional environments and palaeocurrents. This member represents a southward draining sandy braidplain segment forming part of the basin wide Sofia Sund Formation braidplain (Olsen, 1993).

Boundaries. In Gauss Halvø and Moskusokselandet the lower boundary of the member shows a rapid but steady transition upwards from grey or reddish grey pebbly sandstones of similar facies characteristics (undifferentiated Sofia Sund Formation) (Figs 29, 39). This boundary was previously considered the base of the 'Kap-
Graah Series' (Bütler, 1959, pl. 3) and Kap Graah Group (Nicholson \& Friend, 1976, p. 83), see Table 1. It was also shown as the base of the 'Cape Graah Series' on the geological map of Koch \& Haller (1971). On Högbom Bjerg the lower boundary is apparently unconformable to the underlying brownish red sandstones of the Langbjerg Formation (section 13, Fig. 29). Poor exposures prohibit, however, a detailed study of this contact (Fig. 38).

The upper boundary is generally a rapid gradual transition to reddish grey or light grey pebbly sandstones also from the Sofia Sund Formation. In Moskusokselandet near Hoelsbu Fangststation and Forbindelsesdal the member is overlain by a basaltic lava (Figs 29, 38). At western Högbom Bjerg the member is overlain by a red conglomerate of the Sofia Sund Formation. Further east on this mountain this contact becomes an angular unconformity to the Langbjerg Formation. The angular unconformity between the Watson Plateau Member and the overlying undifferentiated Sofia Sund Formation is covered (Fig. 38; Larsen, 1990a).

In northern Gauss Halvø the members exhibit a distinct thinning westwards and finally wedges out at Flett Plateau (Fig. 38). In southern Gauss Halvø a red sandstone unit referred to as the Watson Plateau Member is $500 \mathrm{~m}$ thick on western Smith Woodward Bjerg. In laterally equivalent outcrops west of Paralleldal the member is gradually replaced within $10 \mathrm{~km}$ by sediments of similar facies. These sediments are, however, reddish grey due to a lower content of feldspar grains (c. $5-10 \%$ ) compared to the Watson Plateau Member, although the content is higher than observed in laterally equivalent grey sandstones further west. This probably indicates that the braidplain segment coalesced with other segments to form a broad braidplain (Figs 38, 39).

Distribution. The member crops out in Moskusokselandet, at Högbom Bjerg and in Gauss Halvø (Fig. 38; see also Larsen, 1990a). The red sandstones, mapped as the Watson Plateau Member in the area between Torbern Bergman Bjerg and Snehvide (Fig. 38) were, however, not studied in detail.

Geological age. No fossils were discovered in the member. The position of the member in the middle part of the Sofia Sund Formation probably indicates a Frasnian age.

Fig. 38. Geological map of Gauss Halvø, Moskusokselandet and southern Hudson Land showing the distribution of the Madsen Bjerg Formation and the Watson Plateau Member (Kap Kolthoff Group). Locations of sections 10, 11, 12 and 13 are indicated. 
Fig. 39. Western part of the mountain Smith Woodward Bjerg, bounded to the left by the valley Paralleldal. The mountain ridge is the principal reference section for the Sofia Sund Formation (SS) and type section for the Watson Plateau Member (WP) (see Figs 29, 38). The wedging out of the Watson Plateau Member on the west side of Paralleldal is shown schematically. Maximum height of cliff face seen on this photograph is c. $600 \mathrm{~m}$. The base of the Watson Plateau Member was defined by Nicholson \& Friend (1976) as the base of the Kap Graah Group at this locality.

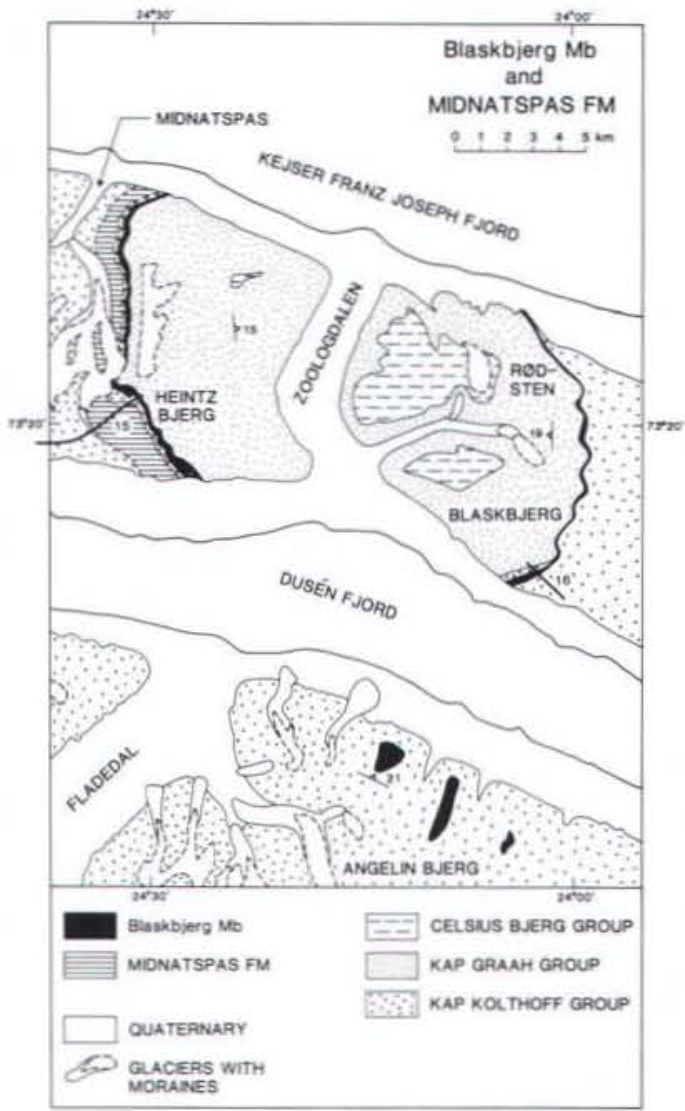

Fig. 40. Geological map of central Gunnar Andersson Land around Zoologdalen showing the distribution of the Blaskbjerg Member and the Midnatspas Formation (Kap Kolthoff Group). Locations of sections 15 and 16 are indicated.

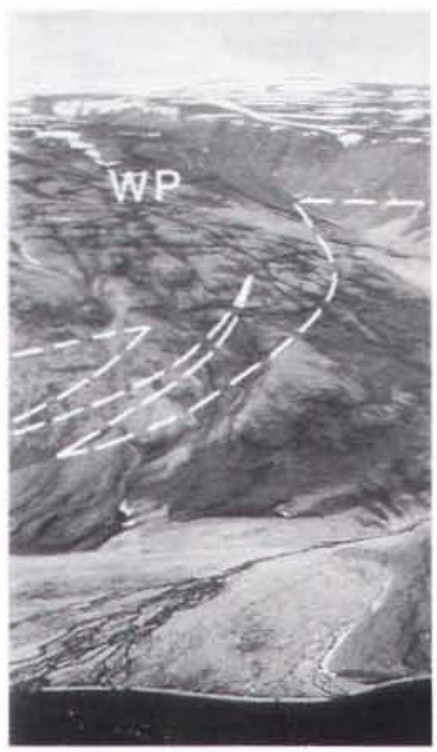

\section{Blaskbjerg Member new member}

Name. After the mountain Blaskbjerg on south central Gunnar Anderson Land (Fig. 40).

Type and reference sections. The type section (Fig. 41) is the mountain Heintz Bjerg west of Zoologdalen, facing the Dusén Fjord (section 15, Figs 30, 40). Reference section is at Blaskbjerg (section 16, Figs 30, 40).

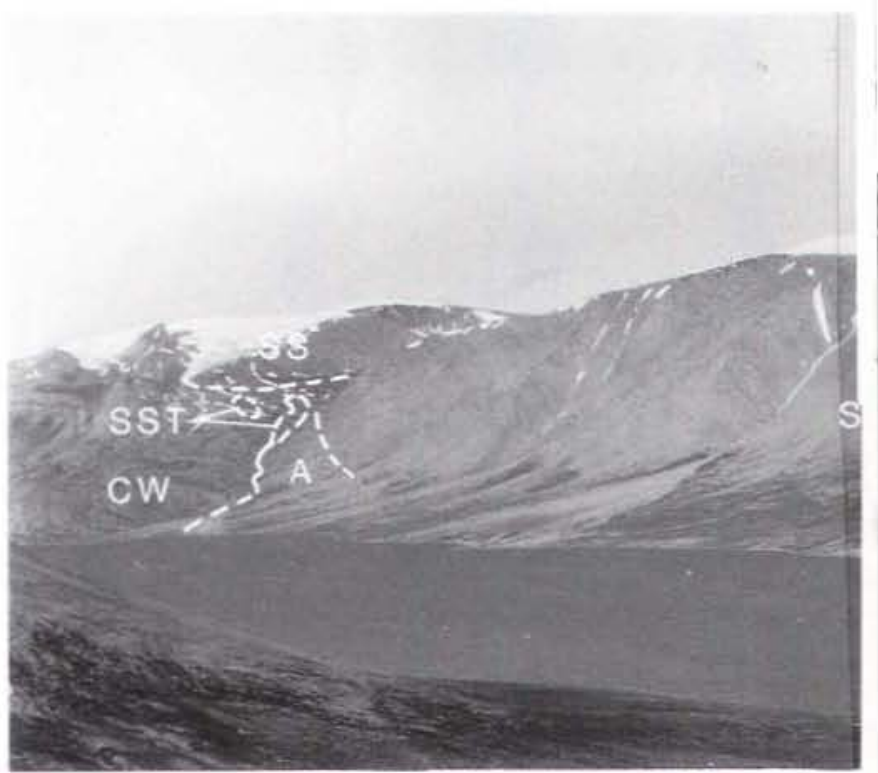




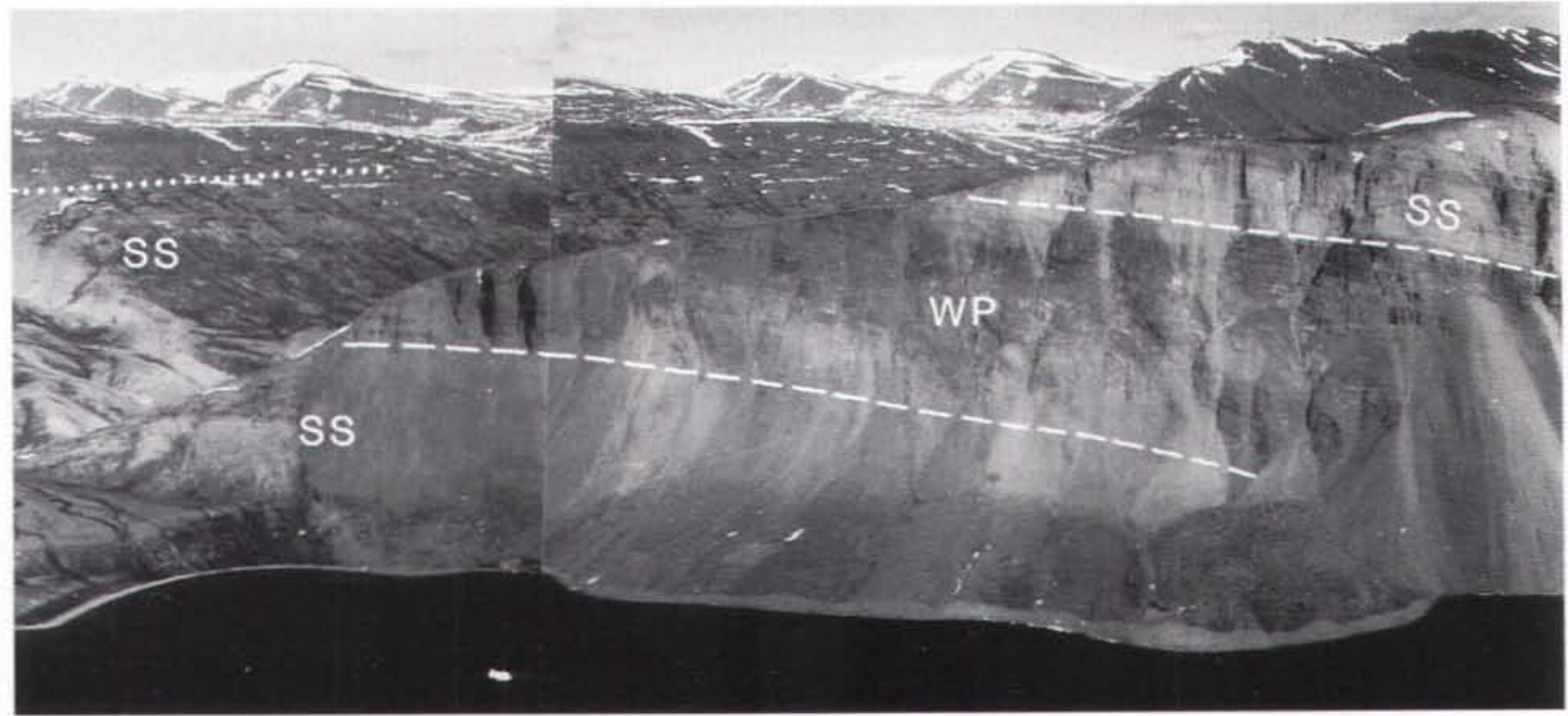

Thickness. The member forms a wedge in the Sofia Sund Formation, decreasing in thickness and disappearing towards the west. It attains a maximum thickness of c. $150 \mathrm{~m}$ on the mountain immediately west of Zoologdalen.

Lithology and sedimentary structures. The member is characterized by medium and coarse-grained trough cross-bedded grey sandstones. Subordinate facies are up to $2.5 \mathrm{~m}$ thick wedge-shaped cross-sets, parallel lamination and rare cross-lamination. Extraformational pebbles form generally $2-10 \%$, usually occurring dispersed in the sandstones but also occasionally as up to $10 \mathrm{~cm}$ thick conglomeratic horizons.

Depositional environments and palaeocurrents. The member represents a southeastward draining sandy braidplain segment (Olsen, 1993).

Boundaries. The lower boundary is defined by an abrupt upward change from white or light grey sandstones of other parts of the Sofia Sund Formation. The

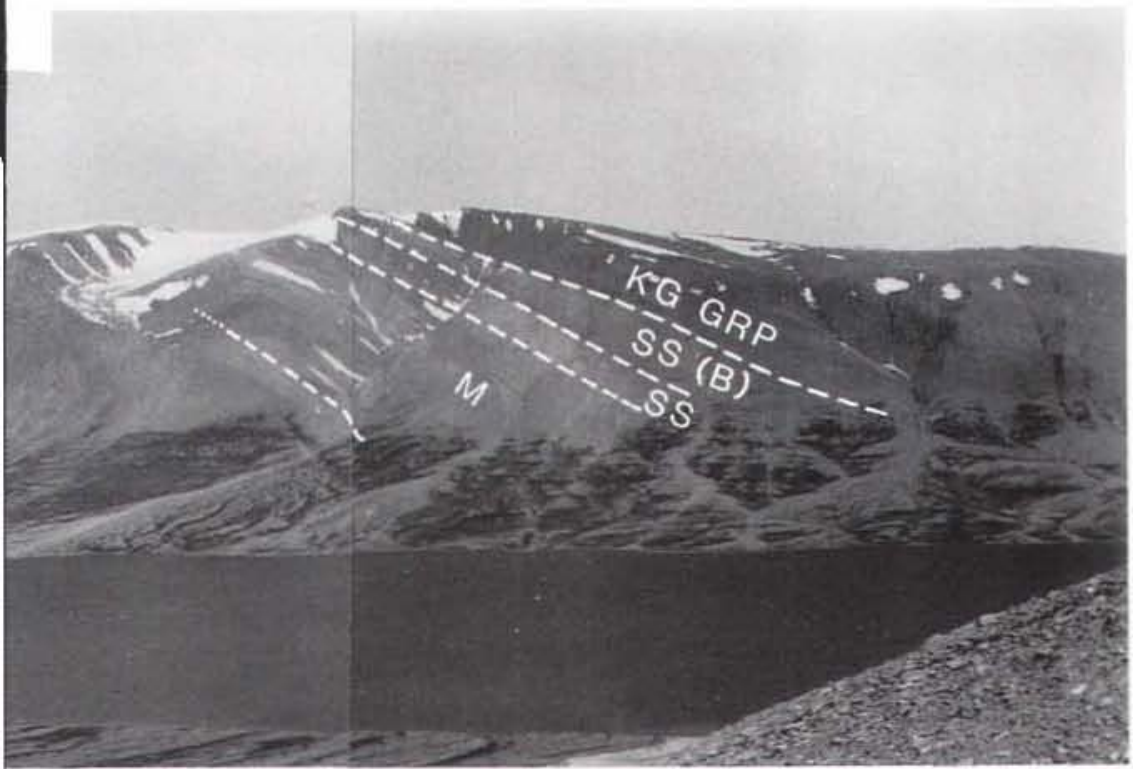

Fig. 41. Section 15 of the Kap Kolthoff Group (see Figs 30, 40, 81) exposed in the mountain Heintz Bjerg in Gunnar Andersson Land. It is the type section for the Sofia Sund (SS) and Midnatspas (M) Formations and the Blaskbjerg Member (B). The lower part of section 25 in the Kap Graah Group (KG GRP) is also visible. In the distance the Sofia Sund Formation overlies sandstones of the Ankerbjergselv Formation (A), conglomerates of the Solstrand Formation (SST) and carbonates of the Ordovician Cape Weber Formation (CW). Height of mountain near the base of the Kap Graah Group is c. $1500 \mathrm{~m}$. 
upper boundary, exposed west of Zoologdalen (Fig. 41 ), is defined by an upward change to interbedded siltstones and sandstones of the Zoologdalen Formation. On Rødsten the upper boundary is defined by an upward change to red sandstones of the Udkiggen Formation of the Kap Graah Group. The upper boundary, exposed on Blaskbjerg, is defined by an upward change to red sandstones (undifferentiated Sofia Sund Formation) (Fig. 40).

Distribution. The member crops out on Ymer $\emptyset$ on both sides of Dusén Fjord (Fig. 40) and possibly also on Geographical Society $\emptyset$ (Larsen, 1990a).

Geological age. No fossils were discovered in the member. It occurs, however, in the uppermost part of the Sofia Sund Formation and an early Famennian age is accordingly assigned to it.

\section{Teglbjerg Member new member}

History. This member was informally referred to as the 'lower pebbly sandstone division' by Nicholson \& Friend (1976, p. 36) in the Kap Graah area.

Name. After the mountain Teglbjerg on eastern Ymer $\emptyset$ (Fig. 42), where the formation forms the top and western flank.

Type and reference sections. Type section is Kap Graah (section 17, Figs 30, 42, 43). The detailed section is also from this locality (Fig, 44).

Thickness. The member forms a wedge in the Sofia Sund Formation, decreasing in thickness and disappearing towards the west. It attains a maximum thickness of c. $200 \mathrm{~m}$.

Lithology and sedimentary structures. The member is composed of medium to very coarse-grained pebbly sandstones (Fig. 44). Sedimentary structures are trough and planar wedge-shaped cross-bedding. Extraformational pebbles form $5-10 \%$ of the sediment, and generally occur dispersed in the sandstones. Locally sandstone cobbles and volcanic cobbles abound. The sediments are red (pink).

Depositional environment and palaeocurrents. The sandstones were deposited as a southwestward draining braidplain segment (Olsen, 1993).

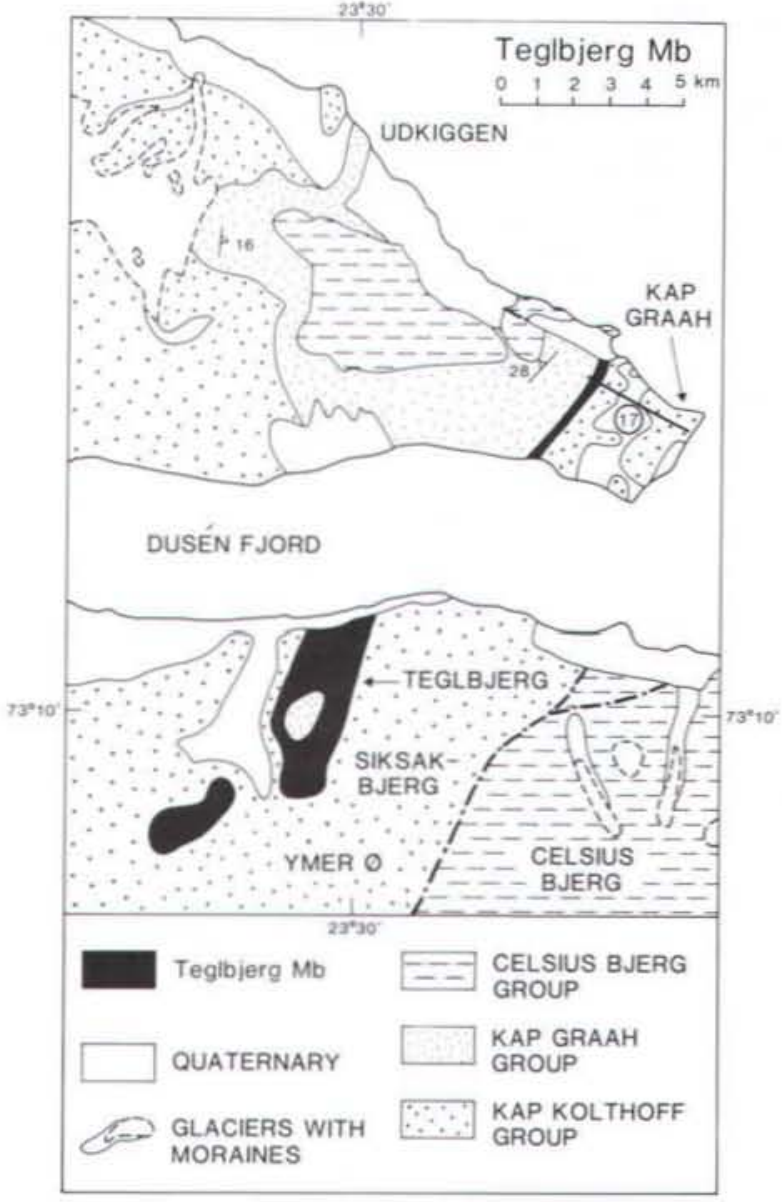

Fig. 42. Geological map of the Kap Graah area showing the distribution of the Teglbjerg Member (Kap Kolthoff Group), Location of section 17 is indicated.

Fig. 43. Aerial photograph of Kap Graah and eastern Udkiggen in Gunnar Andersson Land showing a syncline with a northward dipping axis. The Teglbjerg Member (T) of the Sofia Sund Formation (SS) is overlain by the Udkiggen Formation (U) and Rødsten Formation (R) of the Kap Graah Group. These deposits are succeeded by the Agda Dal Formation (AGD) which follows conformably in the core of the syncline but overlies the Kap Graah Group with an angular unconformity in the western limb of the syncline. The sediments in the core of the syncline are probably older than those in the limb area to the west. The Agda Dal Formation is succeeded by the Elsa Dal (ED) and Aina Dal (AD) Formations. These formations also occur north of a coast-parallel fault zone and on Vinter Øer seen east of Kap Graah. The Teglbjerg Member is underlain by a tabular basaltic unit and several volcanic valleyfills (VVF) of which one is clearly visible on the photograph. The base of these volcanic rocks was previously defined as the base of the Kap Graah Group by Nicholson \& Friend (1976). Copyright Kort- og Matrikelstyrelsen, Denmark, route $872 \mathrm{~N}$. no 353 (A. 200/87) 


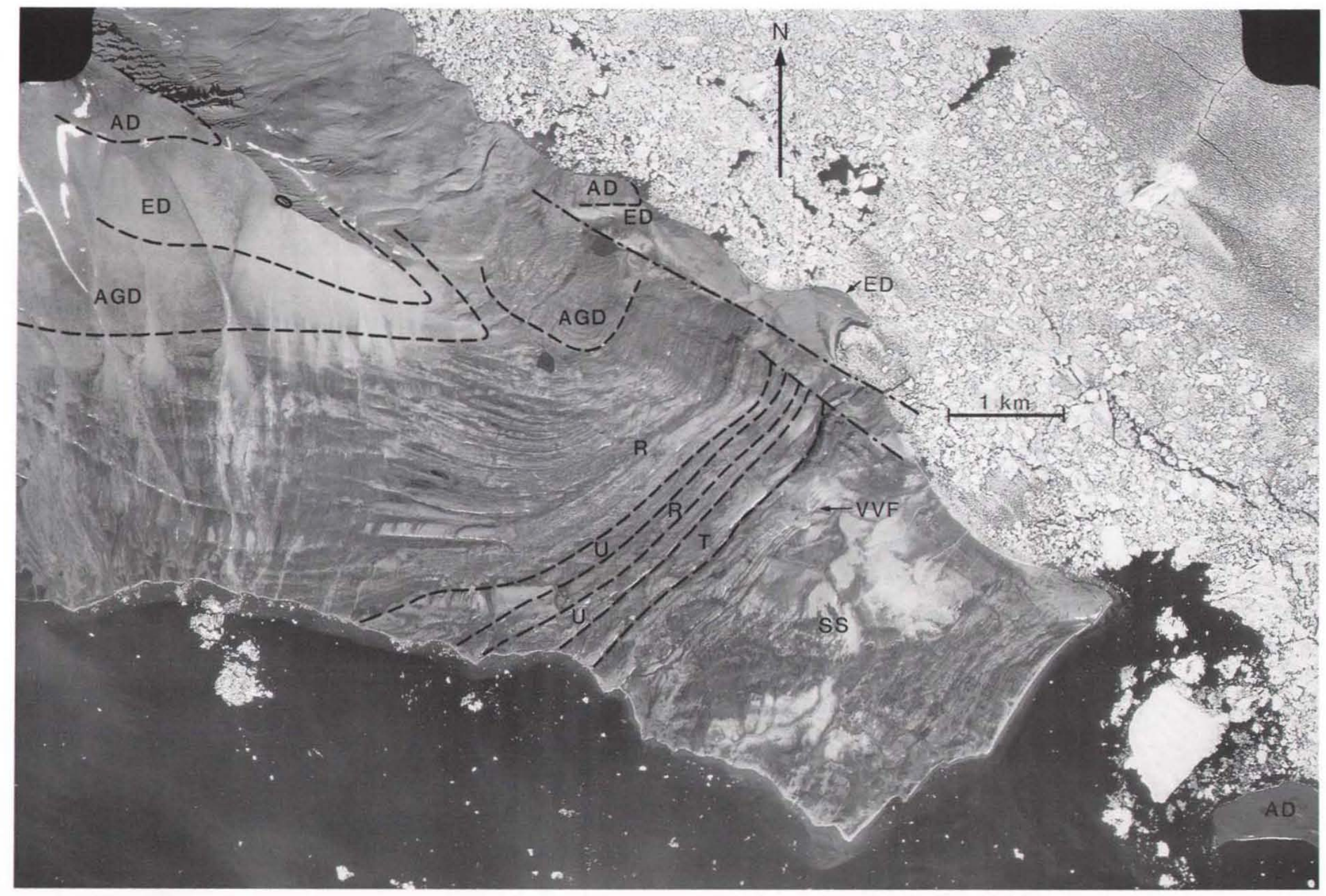




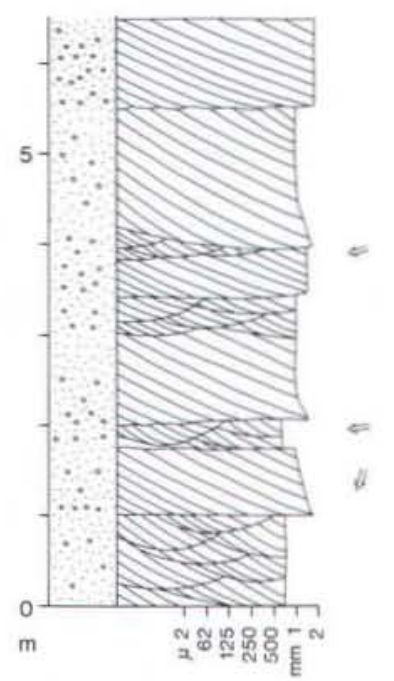

Fig. 44. Facies log from the type section of the Teglbjerg Member (Sofia Sund Formation), measured c. $200 \mathrm{~m}$ below the contact to the Kap Graah Group at Kap Graah (section 17. Figs 30, 42). Legend: Plate. Except for the red or pink colour the member is generally similar to the rest of the sandstones in the Sofia Sund Formation at this locality, although pebbles and cobbles of sandstone and volcanic rocks abound in the lower few tens of metres of the member.

Boundaries. At Kap Graah the member locally overlies a volcanic unit and locally overlies white sandstones of other parts of the Sofia Sund Formation (Figs 42, 43; Larsen, 1990a). Above this contact volcanic and sandstone cobbles abound. The upper boundary is defined by a change from red pebbly sandstones of the Teglbjerg Member to red pebbly free sandstones of the Udkiggen Formation of the Kap Graah Group. At Teglbjerg the lower boundary is defined by an upward change from white pebbly sandstones (undifferentiated Sofia Sund Formation) to red pebbly sandstones of the Teglbjerg Member. Here the upper boundary was not studied by us. On aerial photographs a slightly darker coloured red unit seems to overly the Teglbjerg Member, interpreted to be the Kap Graah Group (Fig. 42).

Distribution. The Teglbjerg Member crops out in eastern Ymer $\emptyset$ at Kap Graah and on Teglbjerg (Fig. 42; Larsen, 1990a).

Geological age. No fossils were discovered in this member. It occurs, however, in the uppermost part of the Sofia Sund Formation and an early Famennian age is assigned to it.

\section{Vergys Formation \\ new formation}

History. This formation includes part of the 'Kap Kolthoff Series' and 'Kap Kolthoff Supergroup' deposits in the Ankerbjergselv area as defined by Bütler (1959) and Alexander-Marrack \& Friend (1976), respectively. It was indicated as 'Cape Kolthoff Series' on the map of Koch \& Haller (1971).

Name. After the mountain Vergys, northeast of Ankerbjergselv, Hudson Land (Fig. 45).

Type and reference sections. The type section is located in the area around Ankerbjergselv in Hudson Land (section 9, Figs 28, 45, 46). The detailed reference section is located immediately NW of the junction between Forbindelsesdal and Ankerbjergselv (Fig. 47).

Thickness. Due to folding and the erosive upper boundary of the formation the thickness of the unit is difficult to measure. However, up to c. $2000 \mathrm{~m}$ has been estimated in the type area (Larsen. 1990d).

Lithology and sedimentary structures. The formation is composed of a basal, $25 \mathrm{~m}$ thick conglomerate with overlying fine-grained sandstones in the Ankerbjergselv area. The conglomerate is grey. whereas the sandstones are green on a freshly broken surface. Both lithologies weather to a distinct buff-yellow colour. The conglomerate is dominated by scour and fill structures and parallel lamination. The clast composition is dominated by carbonate clasts with minor quartzites and crystalline rocks. The sandstones are typically trough and planar cross-bedded. Northwest of the junction between Forbindelsesdal and Ankerbjergselv (Fig. 45) the formation is dominated by fine-grained sandstones (Fig. 47). greenish and reddish grey, weathering buff-yellow. Very fine to fine-grained sandstones and siltstones occur commonly and one black shale unit. $5 \mathrm{~m}$ thick, is also observed. Sedimentary structures in the fine-grained sandstones are similar to the sandstones at other localities, except for the common appearance of convolute bedding. The very fine to fine-grained sandstones and associated siltstones are dominated by parallel lamina-

Fig. 45. Geological map of the Moskusoksefjord area and eastern part of Gauss Halvo showing the distribution of the Langbjerg and Vergys Formations (Kap Kolthoff Group). Locations of sections 9,13 and 14 are indicated. 


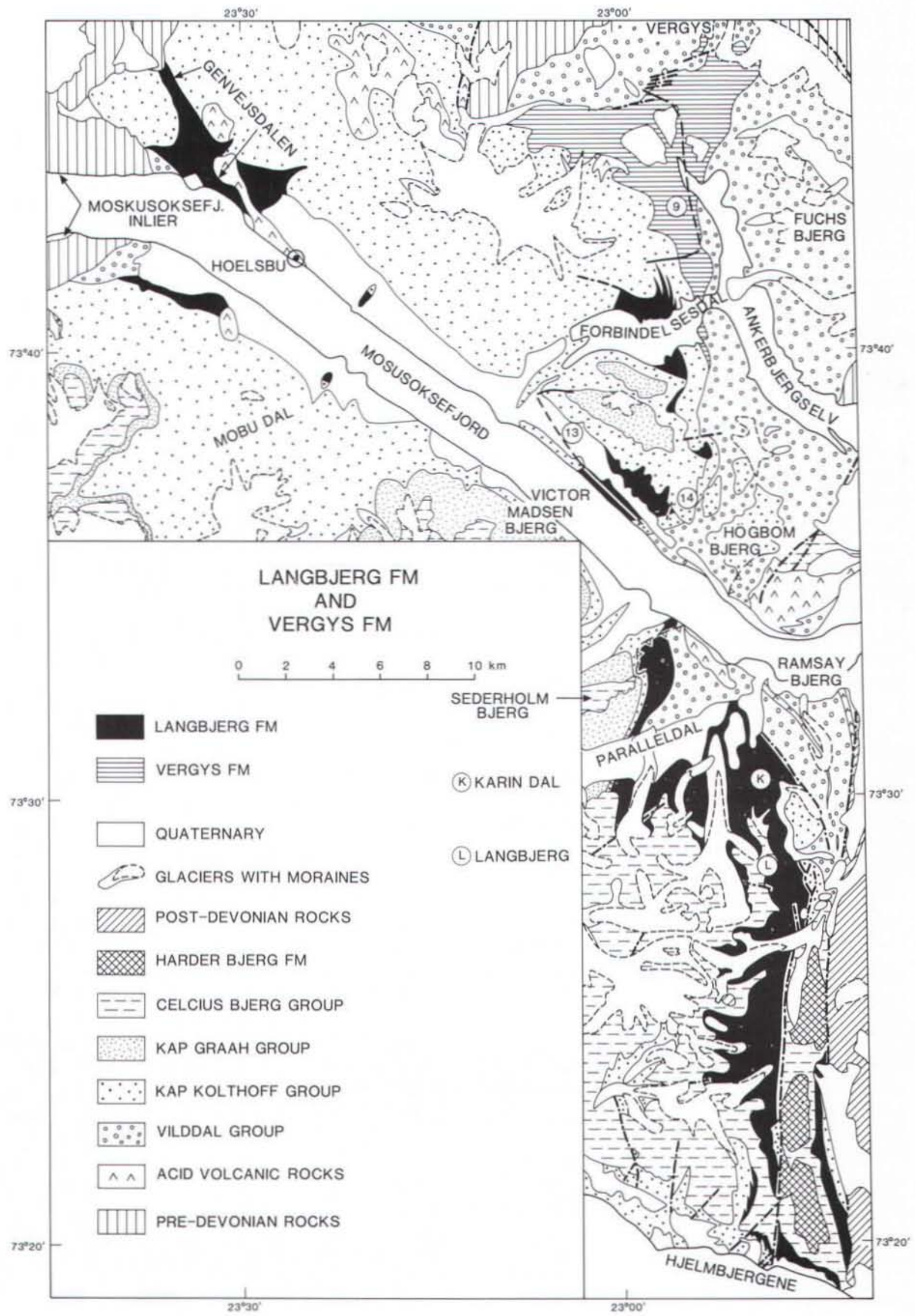


tion, commonly associated with symmetrical ripple forms (wave ripples), and convolute bedding is very common.

Depositional environments and palaeocurrents. The conglomerate was deposited in the proximal part of a braidplain. The cross-bedded sandstones represent sandy braidplain deposition. The finer-grained sediments were deposited in lakes. The depositional subenvironments collectively form a stream dominated system with terminal lakes (Olsen, 1993). Palaeocurrents are directed southeastwards (Olsen, 1993).

Boundaries. The formation rests unconformably on the Ankerbjergselv Formation (Vilddal Group) (Figs 45. 46) (Larsen, 1990d) and is defined by the upward change from red and green sandstones and siltstones to grey conglomerates, weathering buff-yellow. The upper boundary is an unconformity surface. In the field this boundary is locally recognized as an upward change from sandstones, weathered buff-yellow, of the Vergys Formation to grey conglomerates of the Sofia Sund Formation (Larsen, 1990d).

Distribution. The formation crops out in Hudson Land in the vicinity of Ankerbjergselv (Fig. 45; Larsen, 1990a).

Geological age. No fossils were discovered in the formation. It occurs, however, in the lowermost part of the Kap Kolthoff Group and a Givetian age is accordingly assigned to it.

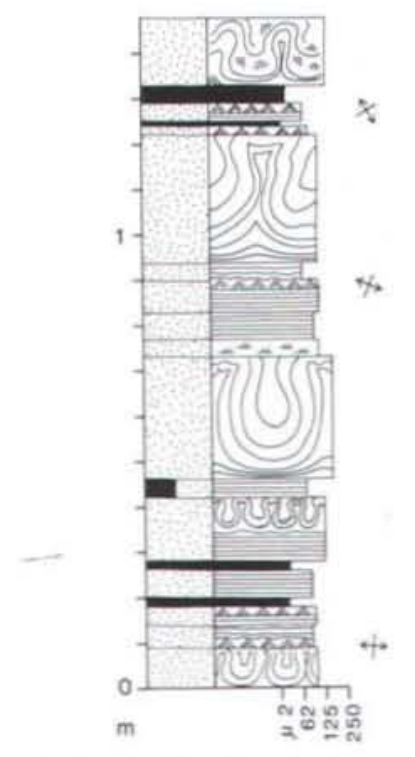

Fig. 47. Detailed facies log from the Vergys Formation in the upper part of type section 9 (Figs 28,45 ) c. $2 \mathrm{~km}$ WNW of the junction between Forbindelsesdal and Ankerbjergselv in Hudson Land. Legend: Plate 2. The section is representative of the upper few hundred metres of the formation preserved below the unconformable contact to the Sofia Sund Formation.

\section{Langbjerg Formation new formation}

History. The formation name is adapted from Alexander-Marrack \& Friend's (1976) 'Red Langbjerg Sandstone', which forms part of this formation. It also includes the 'Hjelmbjergene Red Sandstone' of Alexan-

Fig. 46. Northeastern side of the Ankerbjergselv valley in Hudson Land viewed from the southwest. This is the upper part of section 6 (left) (Figs 8, 12) which is the type section of the Ankerbjergselv Formation (A), and the lower part of section 9 (right) (Figs 28, 45) which is the type section of the Vergys Formation (V). The Vergys Formation is preserved in a synclinal fold with a fold axis dipping towards the SW (see also Larsen, 1990d).

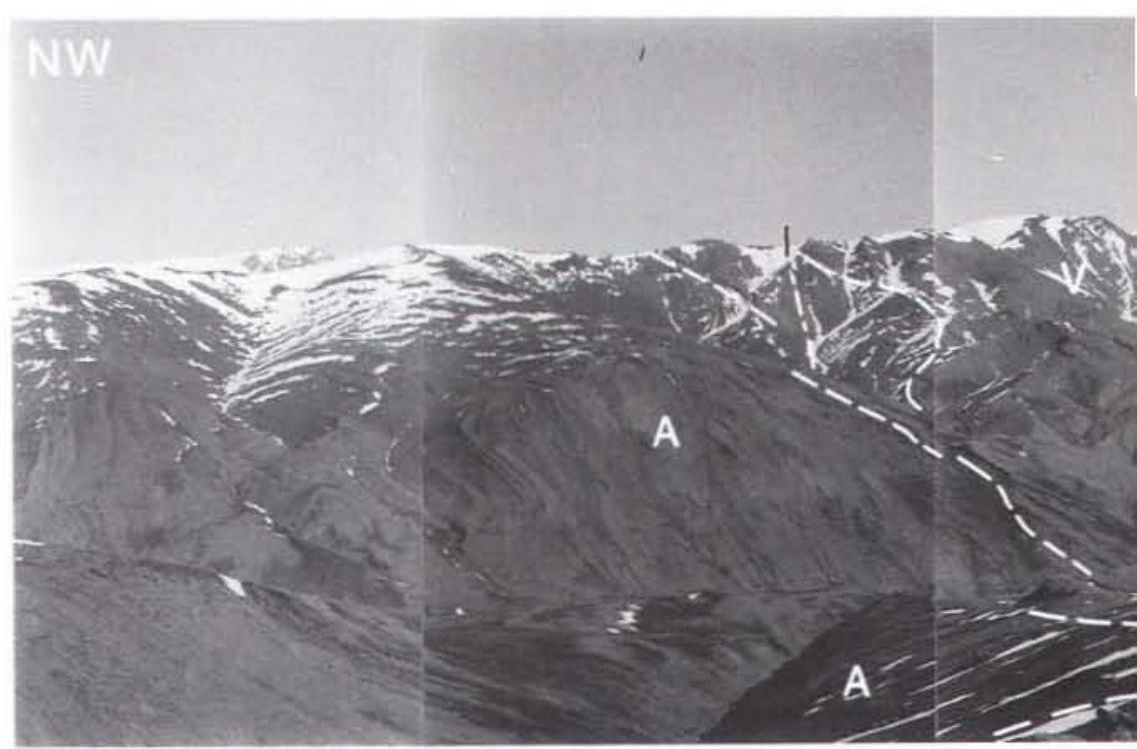


der-Marrack \& Friend (1976) (Fig. 5). These names only served as geographical subdivisions of one genetic unit and are suggested abandoned. Parts of the formation were included in Bütler's (1959) 'Ramsays Bjerg Series' (Fig. 4). The formation was indicated on the map of Koch \& Haller (1971) partly as 'Middle Devonian', and partly as 'Cape Kolthoff Series' and 'Cape Graah Series'.

Name. From Langbjerg, the prominent ridge west of Karin Dal, eastern Gauss Halvø (Fig. 45).

Type and reference sections. The type section is western Högbom Bjerg (section 13, Figs 29, 45). Reference section is a gorge $4 \mathrm{~km} \mathrm{SE}$ of Hoelsbu Fangststation in Moskusokselandet (section 12, Figs 29, 38). From this gorge the detailed section (Fig. 48) is measured.

Thickness. The thickness of the unit has been estimated to $c .600 \mathrm{~m}$ in the Högbom Bjerg - Sederholm Bjerg area.

Lithology and sedimentary structures. The formation is dominated by large-scale trough cross-bedded, fine to medium-grained, brownish red sandstones. The sandstones are characterized by abundant cross-sets thicker than $1 \mathrm{~m}$ (Fig. 49). In the upper few tens of metres of the formation fine-grained, green sandstones alternate with the red sandstones. Also in the Genvejsdalen area and on Sederholm Bjerg green sandstones are important. Changes in colour from brownish red to green are not always associated with the bedding, but commonly

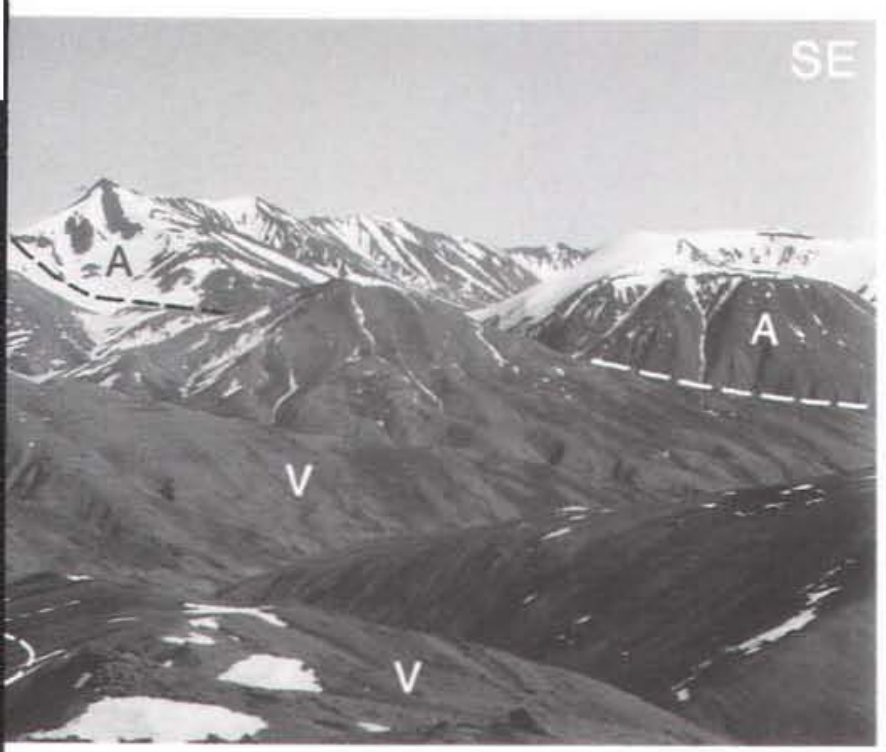

occur laterally within the beds, most pronounced in the Genvejsdalen outcrops (Fig. 45). The colour changes parallel to bedding are mainly ascribed to reduction processes in combination with nearby volcanic activity.

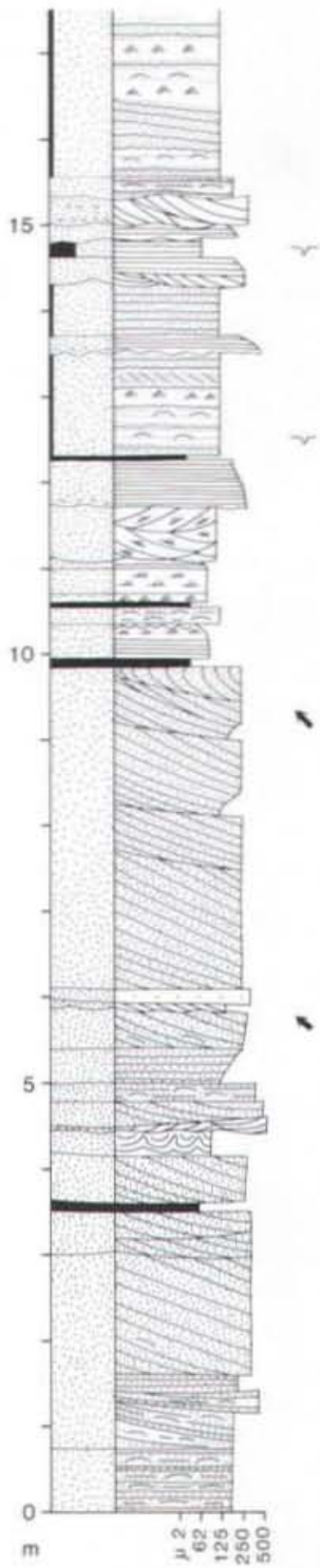

Fig. 48. Facies $\log$ from the Langbjerg Formation in reference section 12 in Moskusokselandet (Figs 29, 38), a gorge c. $4 \mathrm{~km}$ ESE of Hoelsbu Fangststation. The log is measured c. $200 \mathrm{~m}$ below the top of the formation. The lower $10 \mathrm{~m}$ of the logged section are typical of the formation. The upper c. ${ }^{7} \mathrm{~m}$ are only locally important, mostly in the uppermost few tens of metres of the formation. Legend: Plate 2. 


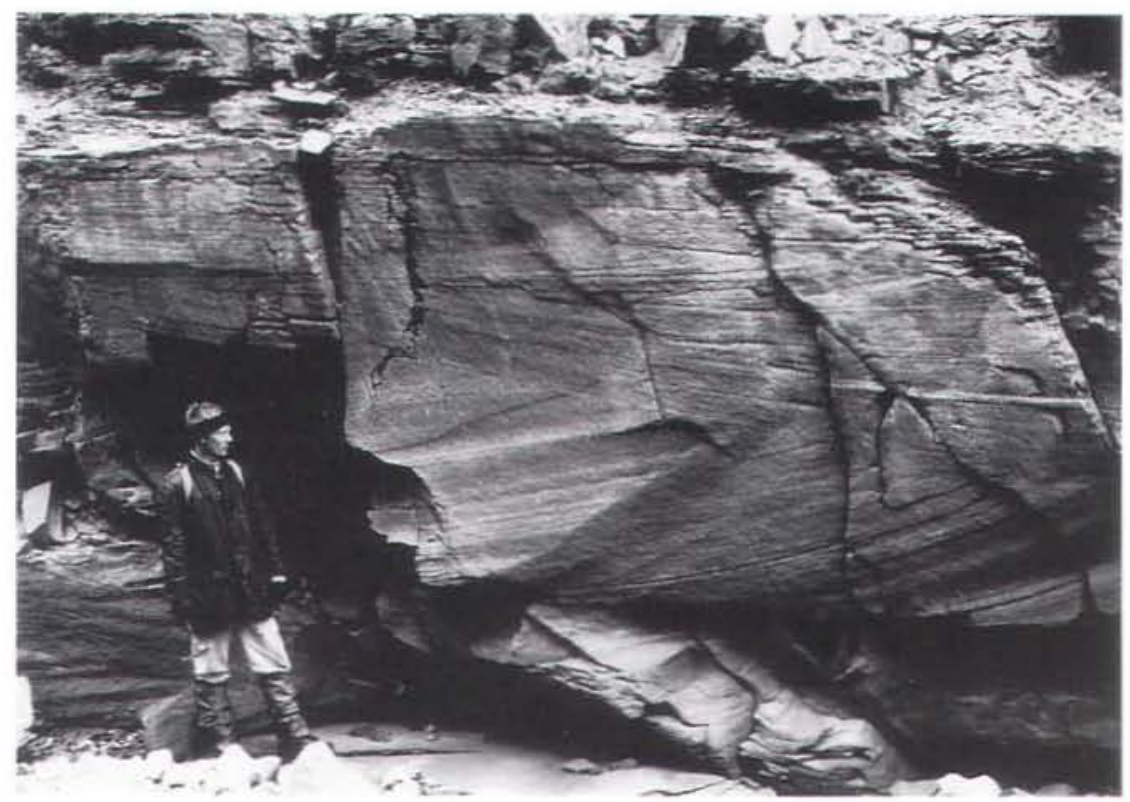

Fig. 49. Sandstones of the Langbjerg Formation, dominated by large-scale cross-bedding, observed in a gorge c. $4 \mathrm{~km}$ ESE of Hoelsbu Fangststation (section 12, Figs 29, 38, 48).

Depositional environments and palaeocurrents. The Langbjerg Formation indicates aeolian deposition. mainly of barchanoid dunes (Olsen, 1993). Aeolian sandsheet deposition and ephemeral stream processes also contributed to the formation. Fluvial deposits become more common in the upper few tens of metres of the formation, forming almost $50 \%$. Palaeowind directions are northwards, palaeocurrents in the fluvial deposits are westwards (Olsen, 1993).

Boundaries. The lower boundary, exposed in the Moskusoksefjord area (Fig. 45), is defined by an abrupt upward change from white or grey sandstones and locally conglomerates of the Sofia Sund Formation to brownish red sandstones of the Langbjerg Formation. The lower boundary, exposed in eastern Hjelmbjergene, is defined by an upward change from green sandstones of the Sofia Sund Formation to brownish red sandstones of the Langbjerg Formation. However, on the southern face of the Hjelmbjergene an interfingering contact seems to occur, but this was only observed from a distance. The upper boundary, exposed in Moskusoksefjord, is defined at an upward change from brownish red and/or green sandstones of the Langbjerg Formation to grey sandstones of the Sofia Sund Formation (Fig. 15), except at Högbom Bjerg. Here the boundary exposed at western Högbom Bjerg is difficult to recognize. It is defined by an upward change from the brownish red pebble free sandstones of the Langbjerg Formation to lighter red pebbly sandstones of the Watson Plateau Member (Sofia Sund Formation). The contact is apparently unconformable. At central Högbom
Bjerg the Langbjerg Formation is unconformably overlain by a red conglomerate of the Sofia Sund Formation. From Högbom Bjerg the formation wedges out towards the north with an interdigitating contact to red and grey sandstones of the Sofia Sund Formation (Fig. 45). In Hjelmbjergene the upper contact is defined by a parallel unconformity. This surface is underlain by brownish red sandstones of the Langbjerg Formation and overlain by light grey or reddish grey conglomerates and pebbly sandstones of the Agda Dal Formation (Celsius Bjerg Group; Fig. 45).

Distribution. The formation crops out in the vicinity of Moskusoksefjord and in an area from Langbjerg to Hielmbjergene in Gauss Halvø (Fig. 45: Larsen. 1990a).

Geological age. Lack of fossils in this formation prohibits a precise age determination. The age may be late Middle Devonian to early Late Devonian.

\section{Barnabas Dal Formation new formation}

History. The formation was indicated as part of 'Middle Devonian' on the map of Koch \& Haller (1971).

Name. After Barnabas Dal east of Rødebjerg on southern Ymer $\emptyset$ (Fig. 50). 


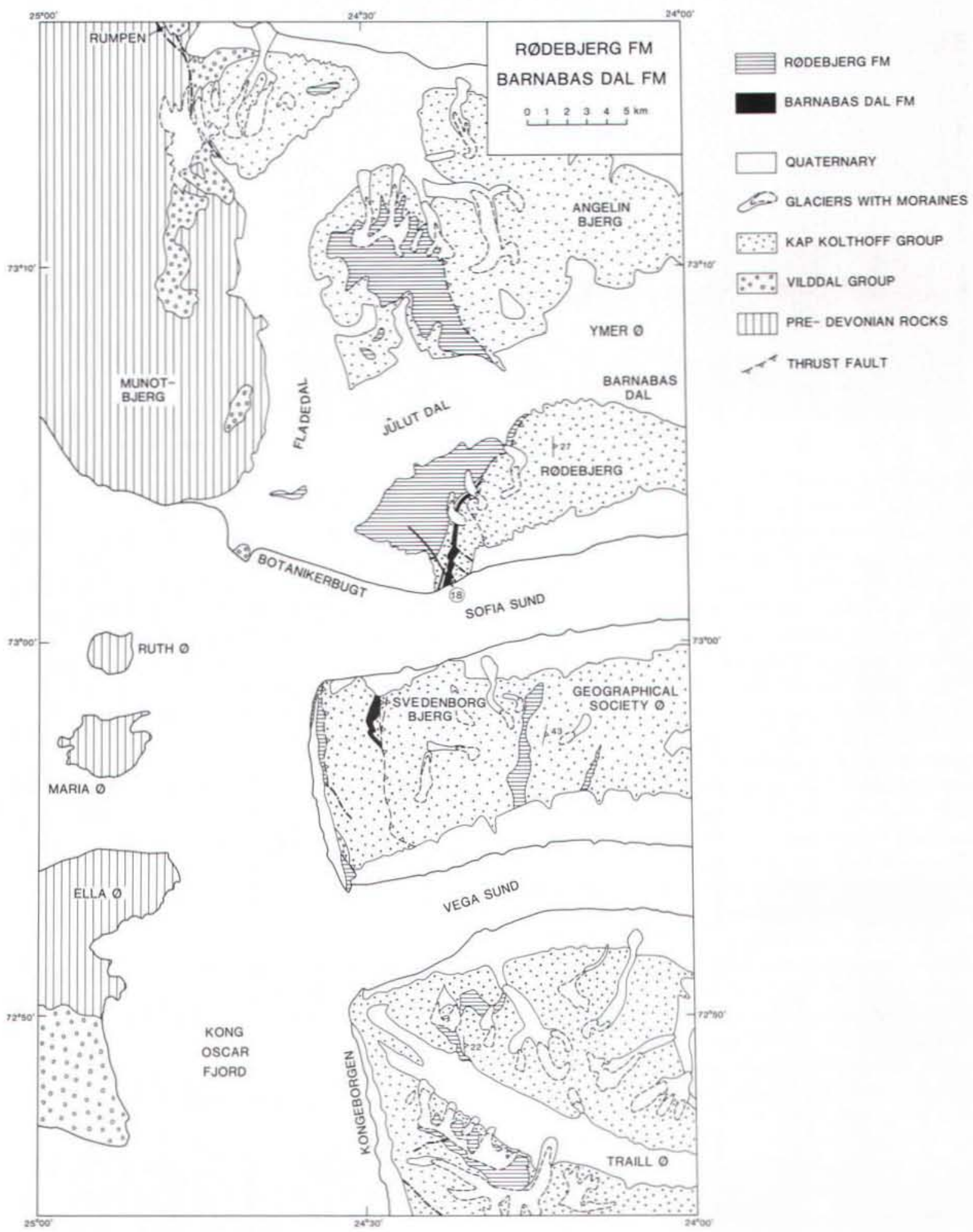

Fig. 50. Geological map of the area around the northern part of Kong Oscar Fjord showing the distribution of the Rødebjerg and Barnabas Dal Formations (Kap Kolthoff Group). The location of section 18 is indicated. 


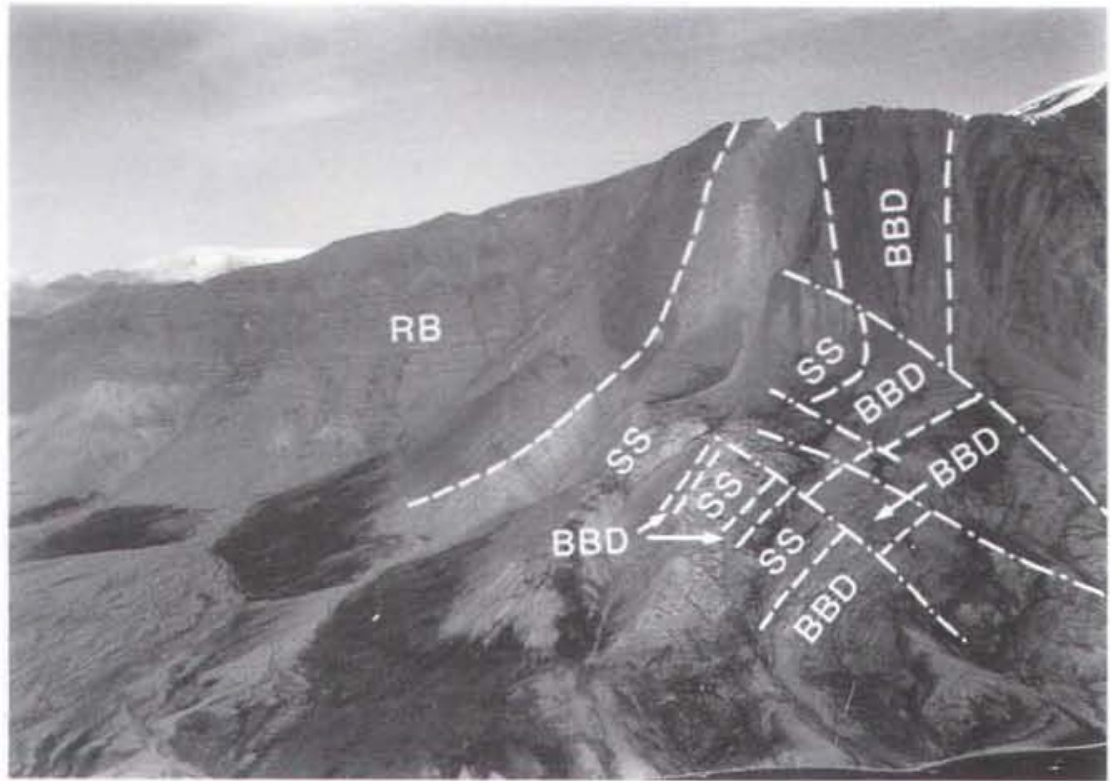

Fig. 51. The mountain Rødebjerg on southern Ymer $\emptyset$, facing Sofia Sund. This is type section 18 (Figs 31, 50) for the Barnabas Dal Formation (BBD) and Rodebjerg Formation (RB) and reference section for the Sofia Sund Formation. Highest point visible on Rodebjerg is c. $1300 \mathrm{~m}$ above sea level.

Type section. The type section is at Rødebjerg, southern Ymer $\emptyset$ (section 18, Figs 31, 50, 51).

Thickness. At Rødebjerg three wedges of the formation have been measured having thicknesses of $350 \mathrm{~m}, 50 \mathrm{~m}$ and $20 \mathrm{~m}$. respectively (Fig. 51).

Lithology and sedimentary structures. The formation is characterized by red fine and medium-grained sandstones. In detail the sandstones exhibit an alternation of red sandstones and variegated red and reddish grey sandstones. Dominant sedimentary structures are trough cross-bedding on a very large scale with individual sets commonly exceeding $1 \mathrm{~m}$ in thickness (Fig. 52). Subordinate sedimentary structures are parallel lamination and irregular lamination. The cross-bedded units are either red or variegated, whereas the parallel laminated and irregularly laminated units are always red.

Depositional environments and palaeocurrents. The formation represents mainly aeolian deposition (Olsen, 1993). Migrating dunes were responsible for the majority of the formation, represented by the trough cross-

Fig. 52. Very large-scale trough cross-bedding (person for scale) in the Barnabas Dal Formation at type section 18 (Figs 31.50 ) at Rodebjerg, Ymer $\emptyset$. The photograph was taken $c$. $300 \mathrm{~m}$ above the base of the formation. Up is to the left; the sediments are tilted to an almost vertical position.

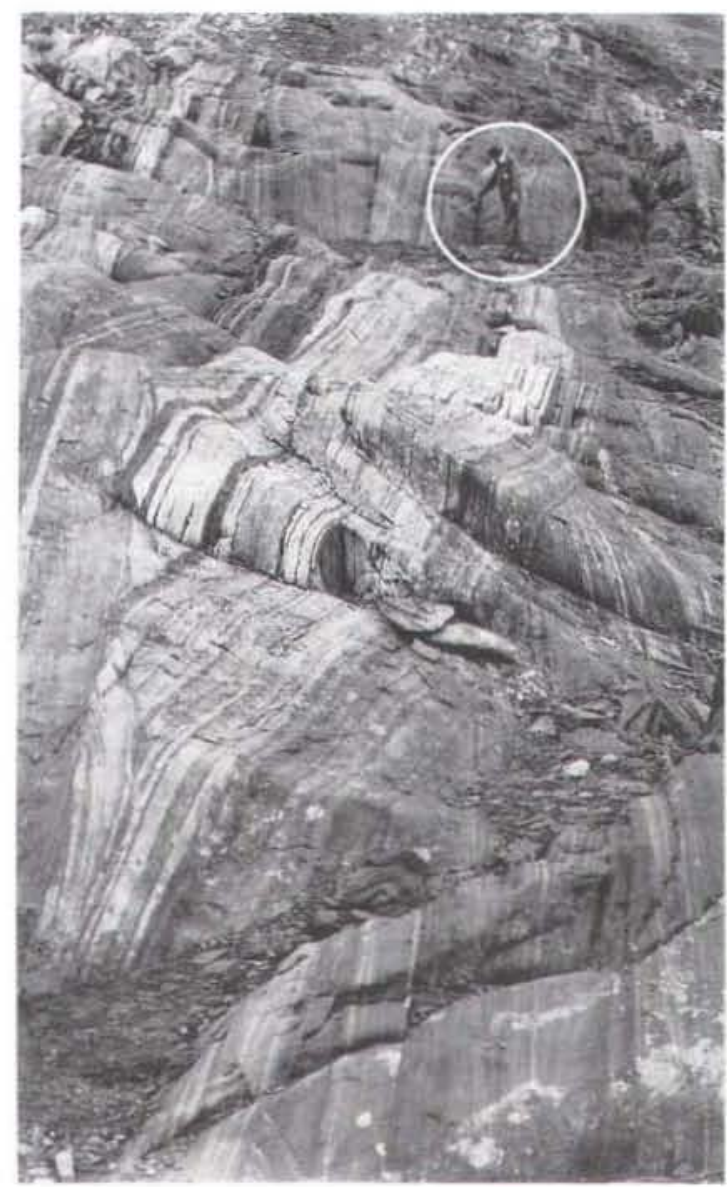


bedded parts. Aeolian sandsheets or interdunes were also important contributors, indicated by the parallel laminated and irregularly laminated units. Ephemeral streams were of only minor importance. Palaeowind blew from the southeast (Olsen, 1993).

Boundaries. Boundary relations were only observed in detail at Rødebjerg (Fig. 50). The lower boundary is taken at the base of the red sandstones resting on the greenish grey sandstones with minor red sandstones of the Sofia Sund Formation. The upper boundary is an interdigitation with the Sofia Sund Formation (Fig. 51). A c. $350 \mathrm{~m}$ thick unit of the red Barnabas Dal Formation is sharply overlain by a $c .100 \mathrm{~m}$ grey sandstone unit of the Sofia Sund Formation. With a gradational contact c. $50 \mathrm{~m}$ of red sandstones follow, taken to be a wedge of the Barnabas Dal Formation. These again are succeeded with a sharp contact by $100 \mathrm{~m}$ white pebbly sandstones of the Sofia Sund Formation. A c. $20 \mathrm{~m}$ thick unit of red sandstones follow, interpreted as a wedge of the Barnabas Dal Formation. This sharply defined unit is overlain by white pebbly sandstones of the Sofia Sund Formation.

Distribution. On Ymer $\emptyset$ the Barnabas Dal Formation crops out at Rødebjerg. On Geographical Society $\emptyset$ to the south, the formation seems to thicken (Larsen, $1990 \mathrm{a})$, but here no detailed sedimentological investigations were carried out.

Geological age. No fossils were identified from this formation. As part of the Kap Kolthoff Group the age of the formation is late Middle Devonian to late Upper Devonian. Fish fossils of probably early Upper Devonian age (Bendix-Almgreen, personal communication, $1990)$ in the stratigraphically younger Rødebjerg Formation may indicate a late Middle Devonian (Givetian) age for the Barnabas Dal Formation.

\section{Rødebjerg Formation new formation}

History. The formation name is adapted from Yeats \& Friend's (1978) 'Lower Rødebjerg Formation' and 'Upper Rødebjerg Formation' (Fig. 5). The formation corresponds to the main, red part of their 'Upper Rødebjerg Formation' on southern Ymer $\emptyset$. It includes, however, also red, green and grey to white sandstones of their Lower Rødebjerg Formation at Rødebjerg. To avoid the use of one geographical name in several lithostratigraphical unit names the early names are sug-
Fig. 53. Facies $\log$ from the Rødebjerg Formation at a locality $c .8 \mathrm{~km}$ SE of Rumpen, Ymer $\varnothing$ (Fig. 50). The $\log$ was measured $c .100 \mathrm{~m}$ above the base of the formation and shows the presence of fluvial sandstones without associated aeolian sandstones. Legend: Plate 2.

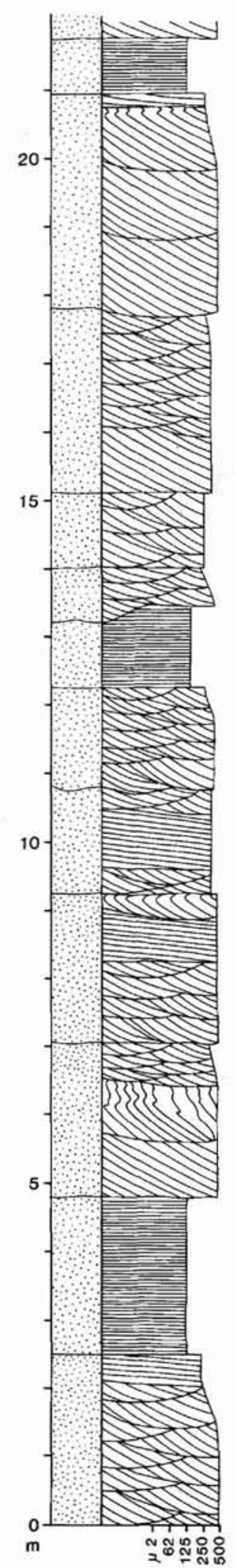



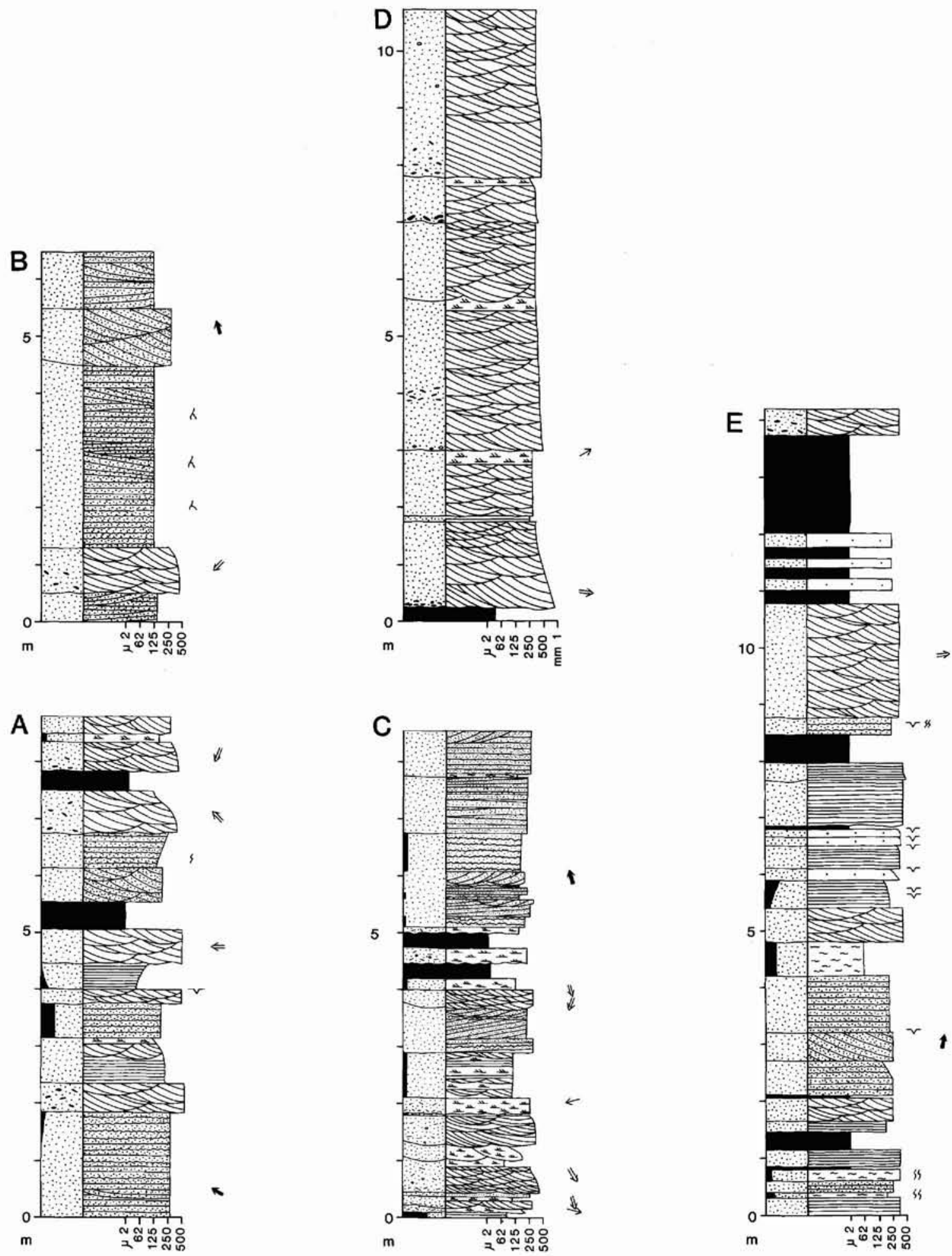

Fig. 54. Facies logs from the Rødebjerg Formation showing close association of fluvial and aeolian sediments in type section 18 (Figs 31, 50) at Rødebjerg. Positions above the base of the formation are (A), c. $185 \mathrm{~m} ;$ (B), c. $195 \mathrm{~m} ;$ (C), c. $410 \mathrm{~m}$; (D), c. $360 \mathrm{~m}$; (E), c. $460 \mathrm{~m}$. Legend: Plate 2. 


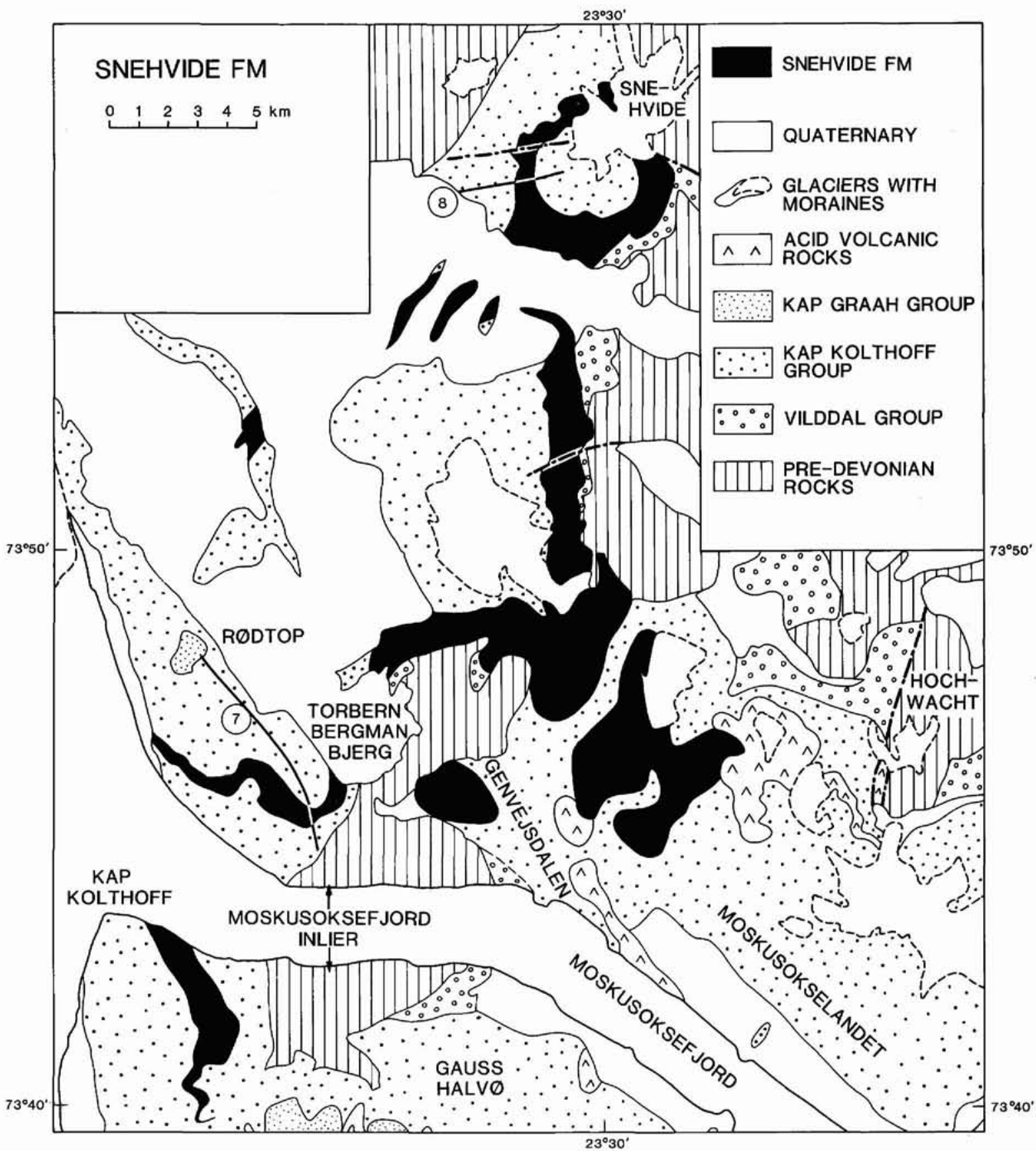

Fig. 55. Geological map of southwestern Hudson Land and northwestern Gauss Halvø showing the distribution of the Snehvide Formation (Kap Kolthoff Group). Locations of sections 7 and 8 are indicated.

gested abandoned. On the map by Koch \& Haller (1971) the formation is partly indicated as 'Middle Devonian' partly as 'Cape Kolthoff Series'.

Name. After Rødebjerg on southern Ymer $\emptyset$ (Fig. 50).

Type and reference sections. The type section is Rødebj- erg (section 18, Figs 31, 50, 51). Detailed reference sections are from the mountain immediately southeast of Rumpen (Figs 50, 53) and Rødebjerg (Figs 50, 54).

Thickness. Only the basal part of the formation is preserved within the main study area, comprising a minimum thickness of $c .900 \mathrm{~m}$, measured on Rødebjerg. 


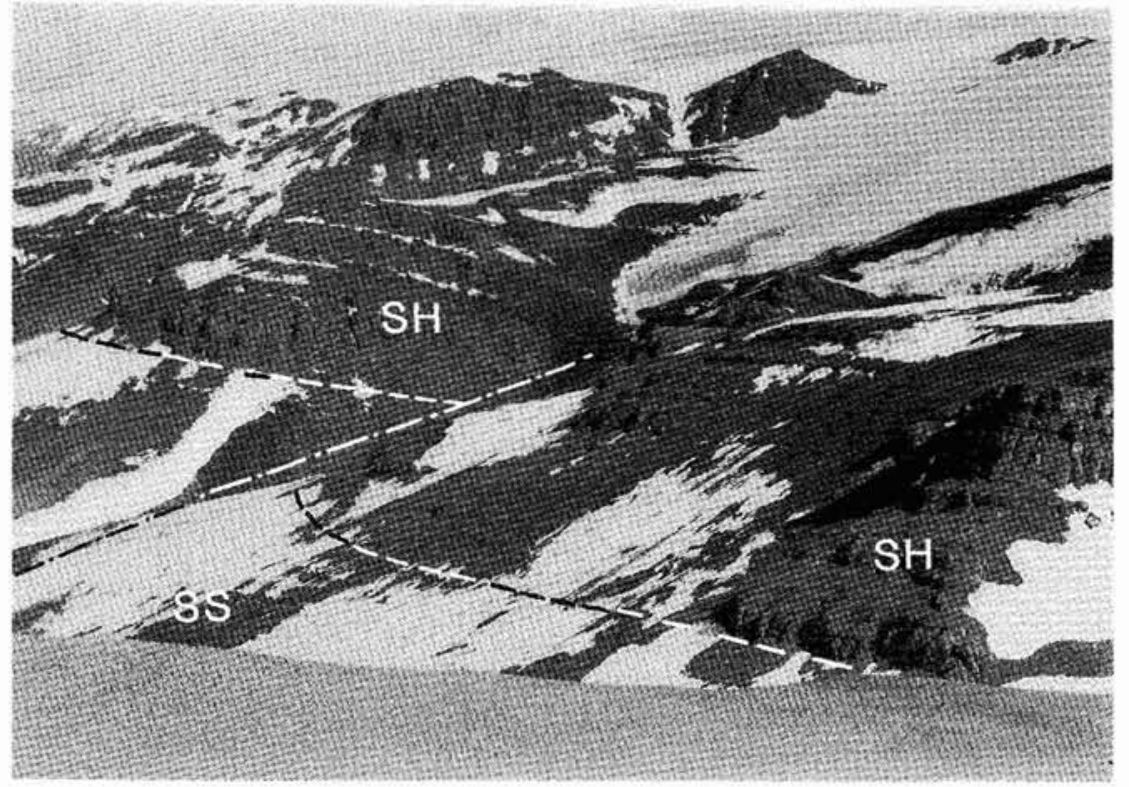

Fig. 56. The mountain Snehvide viewed towards the NE. This is type section 8 (Figs 28,55 ) of the Snehvide Formation (SH) and reference section of the Sofia Sund Formation (SS). The conglomerates are more resistant than the sandstones and form a $c$. $130 \mathrm{~m}$ high cliff. The detailed log in Fig. 57A was measured in the cliff immediately to the right of the centre of the photograph.

Lithology and sedimentary structures. The formation was only studied in detail on Ymer $\emptyset$. The formation is here dominated by medium and fine-grained red, reddish grey and occasionally greenish grey sandstones. Red mudstones form c. $20 \%$ of the formation at $\mathrm{R} \phi$ debjerg (Fig. 54), but are absent in outcrops north of Rødebjerg (Fig. 53). Sedimentary structures are trough cross-bedding, parallel lamination and minor irregular lamination. From a distance the formation seems to be entirely red, but lateral colour changes from greenish grey to red are present on Rødebjerg.

Depositional environments and palaeocurrents. The formation was deposited by a fluvial terminal fan system, and by winds (Olsen, 1993; Kelly \& Olsen, 1993). Palaeocurrents were towards southeast and in this direction the proportion of aeolian deposits also increases (Olsen, 1993). Fluvial deposits are mainly of braided stream origin in the proximal part north of Rødebjerg; in the distal part of the formation increasing amounts of ephemeral stream and aeolian deposits occur. The aeolian sediments were deposited as local sandsheets and dunes. Palaeowinds blew northwards (Olsen, 1993).

Boundaries. The lower boundary is defined by a distinct change from white and grey sandstones of the Sofia Sund Formation to red sandstones of the Rødebjerg Formation. The upper boundary is not exposed on Ymer $\emptyset$. On Geographical Society $\emptyset$ and Traill $\varnothing$ the formation seems to be conformably overlain by white or grey sandstones of the Sofia Sund Formation and to wedge out laterally into this formation (Fig. 50).
Distribution. The formation is exposed along Fladedal on southern Ymer $\emptyset$. It has also been mapped on Geographical Society $\emptyset$ and Traill $\varnothing$ (Larsen, 1990a), but here no detailed sedimentological investigations were carried out (Fig. 50).

Geological age. Fish scales of the Crossopterygian Panderichthys indicates a probable early Late Devonian age; although a latest Middle Devonian age can not be rejected (Bendix-Almgreen, personal communication, 1990). The formation is probably partly Givetian and partly Frasnian in age.

\section{Snehvide Formation}

new formation

History. Outcrops of this formation in the Moskusoksefjord area were referred to as part of the 'Kap Kolthoff Series' and 'Kap Kolthoff Supergroup' by Bütler (1959, p. 50) and Nicholson \& Friend (1976, p. 84), respectively. The formation was partly indicated as 'Middle Devonian' and partly as 'Cape Kolthoff Series' on the map of Koch \& Haller (1971).

Name. After the permanently snow covered mountain top, Snehvide in Hudson Land (Fig. 55).

Type and reference sections. Type section is Snehvide (section 8, Figs 28, 55, 56). Reference section is at Torbern Bergman Bjerg (section 7, Figs 28, 55). De- 
tailed reference sections are shown from Snehvide (Figs 57A-D), Torbern Bergman Bjerg (Figs 57E) and east of Genvejsdalen (Fig. 57F).

Thickness. The thickness of the formation is $c .250 \mathrm{~m}$ on Snehvide. On western Torbern Bergman Bjerg the formation is up to $c .150 \mathrm{~m}$ thick and wedges out in the cliff sections north of Moskusoksefjorden.

Lithology and sedimentary structures. The lithology changes gradually from conglomerates in the northernmost outcrops to mainly fine and medium-grained sandstones, and finally very fine to fine-grained sandstones in the southernmost outcrops of this formation (Fig. 57A-F). The conglomerates are dominated by scour and fill structures, trough cross-bedding and parallel lamination. The fine to medium-grained sandstones are mainly trough cross-bedded, whereas the very fine to finegrained sandstones exhibit low-angle trough cross-bedding and parallel lamination, associated with desiccation cracks. All sediments of the Snehvide Formation are red.

Depositional environments and palaeocurrents. The formation represents a fluvial terminal fan system (Olsen, 1993; Kelly \& Olsen, 1993). The proximal part of the system was composed of gravelly streams and associated overbank areas. The main part of the system was composed of sandy braided streams grading downstream into braided channels with extensive interchannel areas, characterized by sheetfloods. Also in these interchannel areas and at the margin of the system aeolian processes were acting, mainly resulting in small dunes. Palaeocurrents were towards the south, whereas palaeowinds blew from the southeast (Olsen, 1993).

Boundaries. The Snehvide Formation forms a wedge shaped unit within the Sofia Sund Formation, thinning towards west and south (Fig. 55). The lower boundary at Snehvide is taken at the base of the red conglomerates of the Snehvide Formation resting on greenish grey sandstones of the Sofia Sund Formation (Fig. 56). Northwards the conglomerates onlaps the Precambrian Eleonore Bay Group sediments and eastwards on the conglomeratic Solstrand Formation (Vilddal Group; Fig. 55). The top of the Snehvide Formation at this locality is placed where the red sandstones of the formation are succeeded by grey sandstones (conglomeratic at the base) of the Sofia Sund Formation. Further southwest on Torbern Bergman Bjerg the Snehvide Formation, composed of red sandstones, interfingers over 20 $m$ with green sandstones of the Sofia Sund Formation below. The red sandstones also interfinger with grey sandstones of the Sofia Sund Formation above, over a $40 \mathrm{~m}$ interval. Wedging out towards the west is clearly observed at Torbern Bergman Bjerg (Fig. 58). East of Genvejsdalen the red sandstones of the Snehvide Formation rest with a sharp contact on green and red tuffs of the Sofia Sund Formation. Here the top of the Snehvide Formation is not exposed. On Gauss Halvø near Kap Kolthoff a wedge of the Snehvide Formation is observed, wedging out towards the southeast. It is underlain by green sandstones of the Sofia Sund Formation and overlain by grey sandstones also of the Sofia Sund Formation (Fig. 55).

Distribution. The formation crops out in Hudson Land, from Snehvide in the north to Torbern Bergman Bjerg in the south. In Gauss Halvø the formation crops out immediately north of Flett Plateau (Fig. 55; Larsen, 1990a).

Geological age. No fossils were found in this formation. A tentative Givetian to Frasnian age is assigned to it.

\section{Madsen Bjerg Formation}

new formation

History. In Moskusokselandet the formation was included in the 'Kap Graah Series' by Bütler (1959, pl. 3), and in the 'Cape Graah Series' on the map of Koch \& Haller (1971). It was included in the Kap Graah Group by Nicholson \& Friend (1976). On Victor Madsen Bjerg the formation was considered as part of the 'Kap Kolthoff Series' (Bütler, $1959 \mathrm{pl} .3$ ) and the 'Cape Kolthoff Series' (Koch \& Haller, 1971), whereas the map by Nicholson \& Friend $(1976$, p. 8 ) is too simplified to show if the formation was included in their 'Kap Kolthoff Supergroup' or Kap Graah Group. Sedimentological evidence (Olsen, 1993) shows that these sediments may not be part of the Kap Graah Group but instead included in the Kap Kolthoff Group as defined by us.

\section{Name. After Victor Madsen Bjerg in Gauss Halvø (Figs $38,59)$.}

Type and reference section. Northwestern part of Victor Madsen Bjerg (section 11, Figs 29, 38, 59). The reference section is located in Moskusokselandet east of Hoelsbu Fangststation (section 12, Figs 29, 38).

Thickness. The formation attains a maximum thickness of approximately $150 \mathrm{~m}$ at Victor Madsen Bjerg. 
62

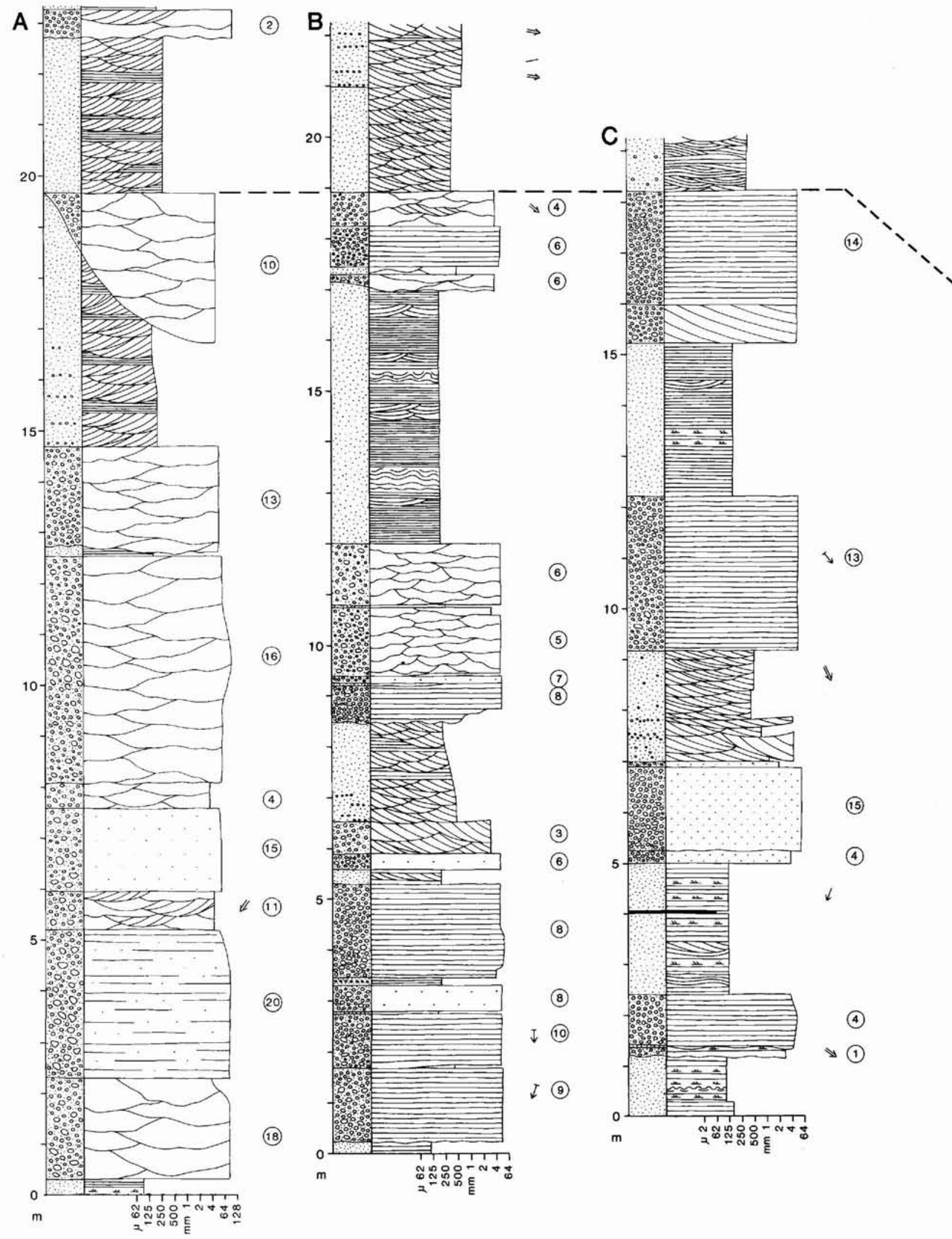

Fig. 57. See opposite page for figure text. 
Lithology and sedimentary structures. The formation is composed of fine and medium-grained red sandstones, dominated by trough cross bedding with individual sets usually exceeding $1 \mathrm{~m}$ in thickness.

Depositional environment and palaeocurrents. The for- mation represents aeolian dune deposition. Palaeowinds blew from the southeast (Olsen, 1993).

Boundaries. At Victor Madsen Bjerg the red pebble free sandstones of this formation are bounded below and above by light grey pebbly sandstones of the Sofia
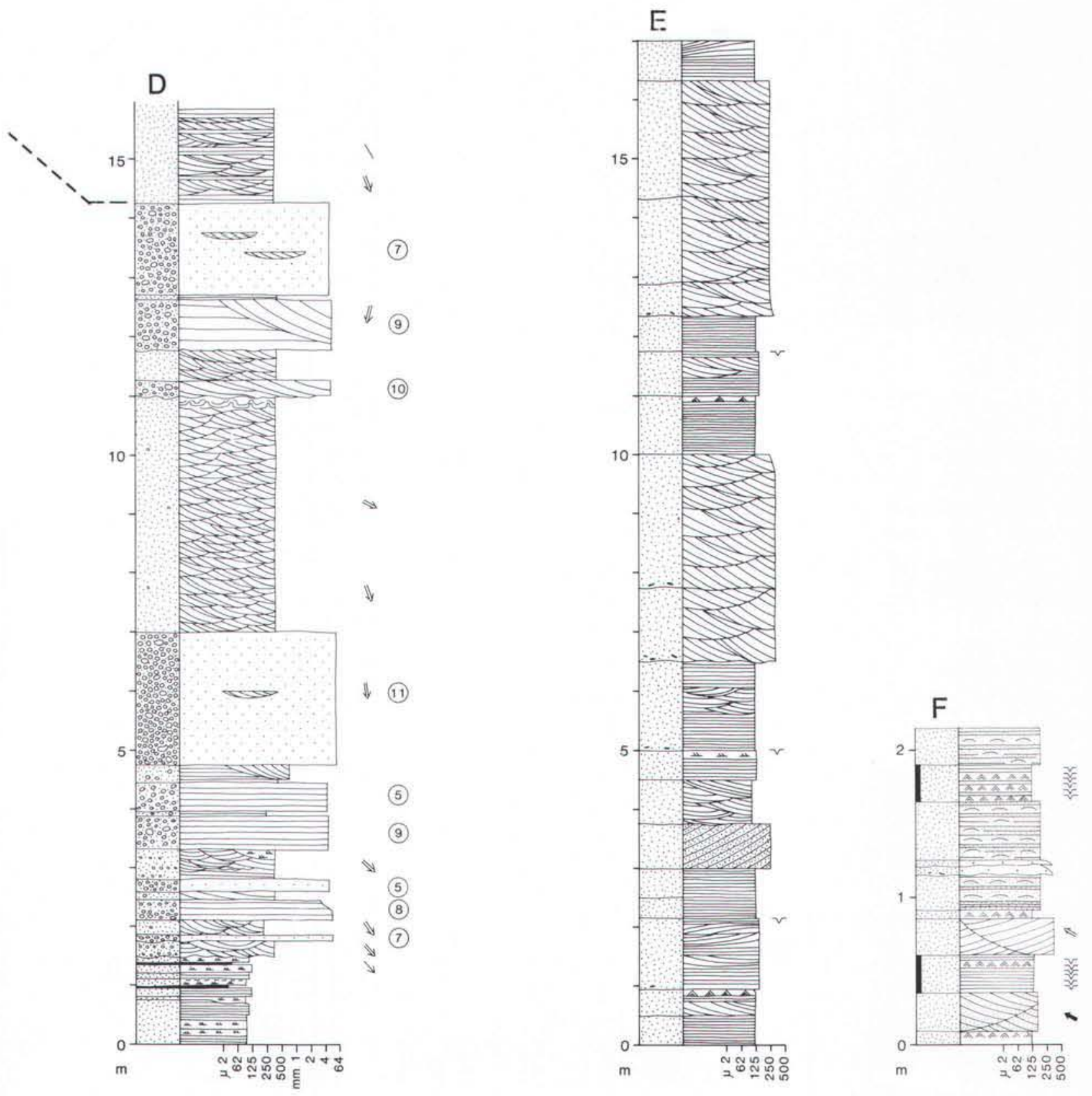

Fig. 57. Facies logs from the Snehvide Formation. A-D are from the type locality, Snehvide in Hudson Land illustrating the conglomeratic lower part of the formation at this locality, c. $60-80 \mathrm{~m}$ above the base. A was measured in type section 8 (Figs 28 , 55): B, C and D were measured c. $1900 \mathrm{~m}, 2700 \mathrm{~m}$ and $3300 \mathrm{~m}$ south of A, respectively. Correlation of sections is shown by dashed line. E, being entirely composed of sandstones, is measured c. $100 \mathrm{~m}$ above the base of the formation in Moskusokselandet $8 \mathrm{~km}$ NNE of the delta of Genvejsdalen (Fig. 55). F is dominated by aeolian sandstones and measured c. $30 \mathrm{~m}$ above the base of the formation $3.5 \mathrm{~km} \mathrm{NE}$ of the delta of Genvejsdalen. Notice the different scale in section F. Legend: Plate 2. 


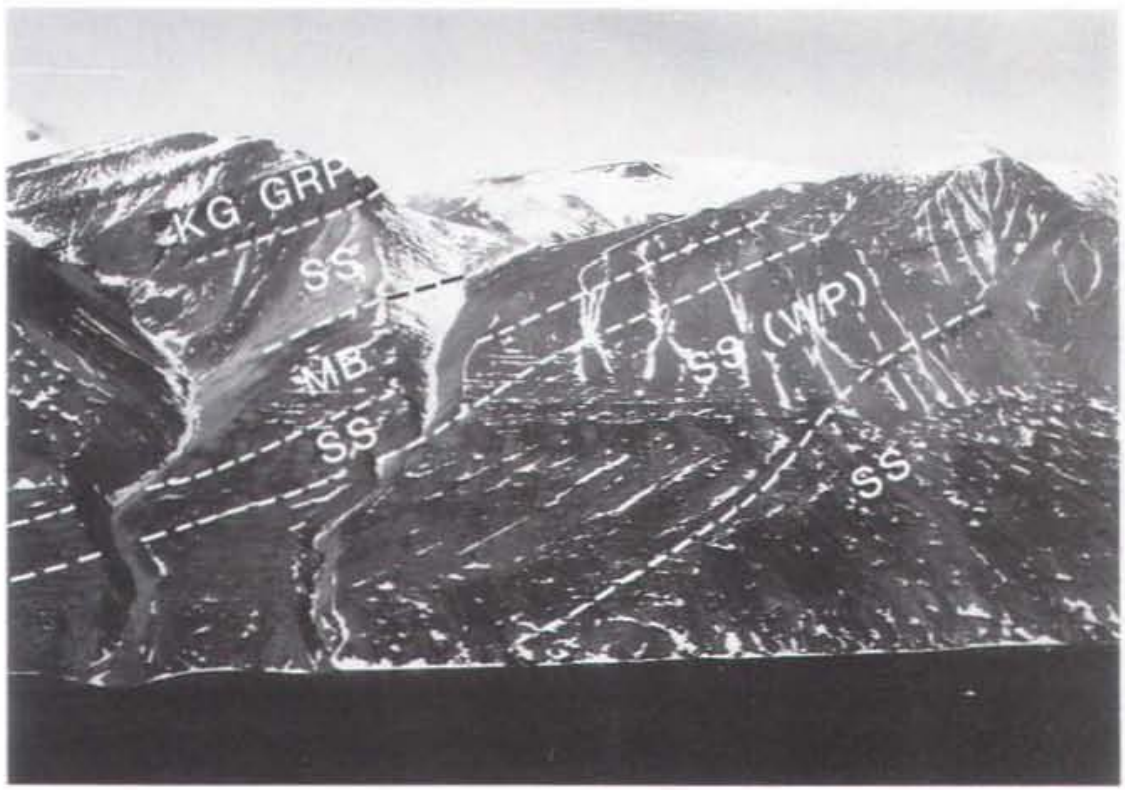

Fig. 59. Northwestern part of the mountain Victor Madsen Bjerg facing Moskusoksefjord. This is type section 11 (Figs 29, 38) of the Madsen Bjerg Formation (MB), and a reference section of the Sofia Sund Formation (SS) including the Watson Plateau Member (WP). The Kap Kolthoff Group sediments are overlain by the Kap Graah Group (KG GRP). Highest point of cliff face in the right part of the photograph is c. $950 \mathrm{~m}$ above sea level.

Sund Formation (Fig. 59). In Moskusokselandet the red pebble free sandstones of the Madsen Bjerg Formation rest on darker red pebbly sandstones of the Sofia Sund Formation. The top of the Madsen Bjerg Formation is not exposed in Moskusokselandet, though a change in colour to grey in the scree covering the mountain north of Hoelsbu Fangststation may indicate a transition to the Sofia Sund Formation (Fig. 38).

Distribution. The formation crops out only in the Moskusoksefjord area; in Moskusokselandet and Gauss Halvø (Fig. 38),
Geological age. No fossils were found in this formation. The position in the upper part of the Kap Kolthoff Group indicates a possible Late Devonian age.

\section{Midnatspas Formation}

new formation

History. This formation was included in the 'Cape Kolthoff Series' on the map of Koch \& Haller (1971) and in the 'Kap Kolthoff Supergroup' by Friend et al. (1983, p. 9).
Fig. 58. The mountain Torbern Bergman Bjerg in Moskusokselandet viewed from the south. Crystalline rocks (CRYST) in the centre of the 'inlier' are covered by pre-Devonian sediments (PDS). These are succeeded by the Sofia Sund Formation (SS) with a wedge of the Snehvide Formation (SH). Section 7 is located at the mountain ridge (see also Fig. 55). The Kap Kolthoff Group is topped by the red coloured and resistant Kap Graah Group (KG GRP) giving the name to the mountain Rødtop (= red top). The highest point of the Torbern Bergman Bjerg is c. $1400 \mathrm{~m}$ above sea level.

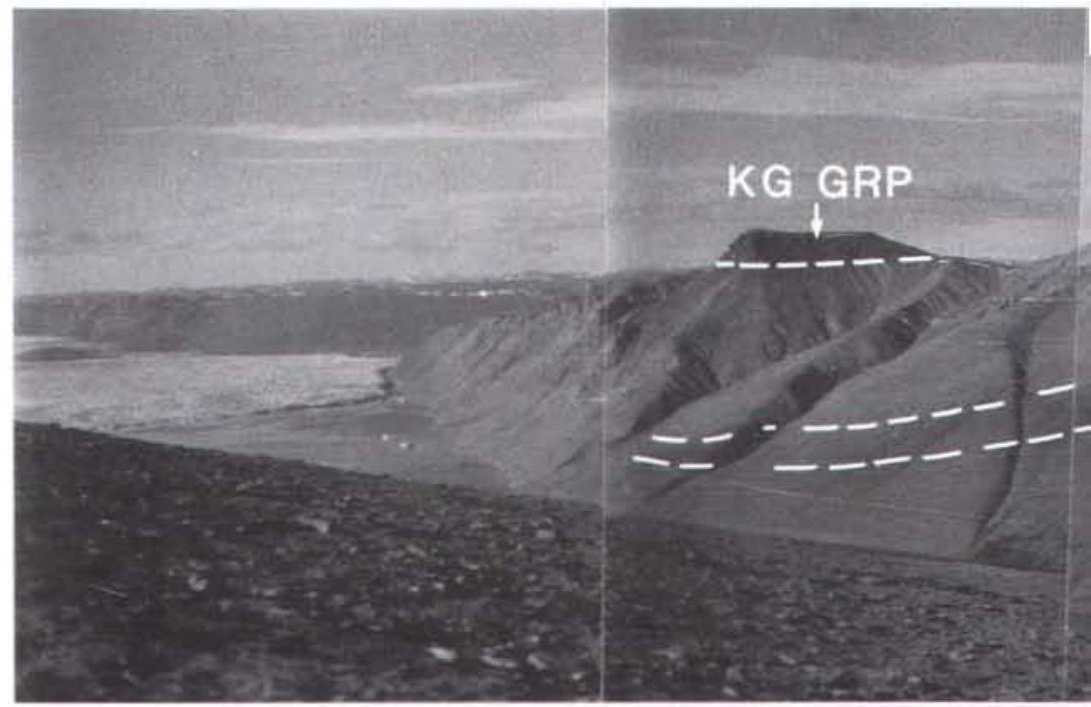


Formation are taken at the base of the lowermost black mudstone bed and at the top of the uppermost black mudstone bed, respectively.

Distribution. The formation crops out between Midnatspas and Zoologdalen on Gunnar Andersson Land (Fig. 40).
Geological age. No identifiable fossils were collected from this formation. The position immediately below the Kap Graah Group indicates, however. an Upper Devonian (early Famennian) age.

\section{Kap Graah Group}

History. Koch (1929b) included the entire Devonian succession in the 'Cape Graah Formation'. Bütler (1935) used the name 'Kap Graah Serien' for the mainly red sediments generally corresponding to the group as now defined by us. He subsequently renamed it the 'Kap Graah Series' (Bütler, 1959) and Cape Graah Se- ries (Bütler, 1961) (Fig. 4). Koch \& Haller (1971) used the last suggestion in their geological map of central east Greenland, based on Bütler's mapping. Finally Nicholson \& Friend (1976) applied the name Kap Graah Group to the lithostratigraphic unit (Figs 4,5), although they never defined any constituent formations. While
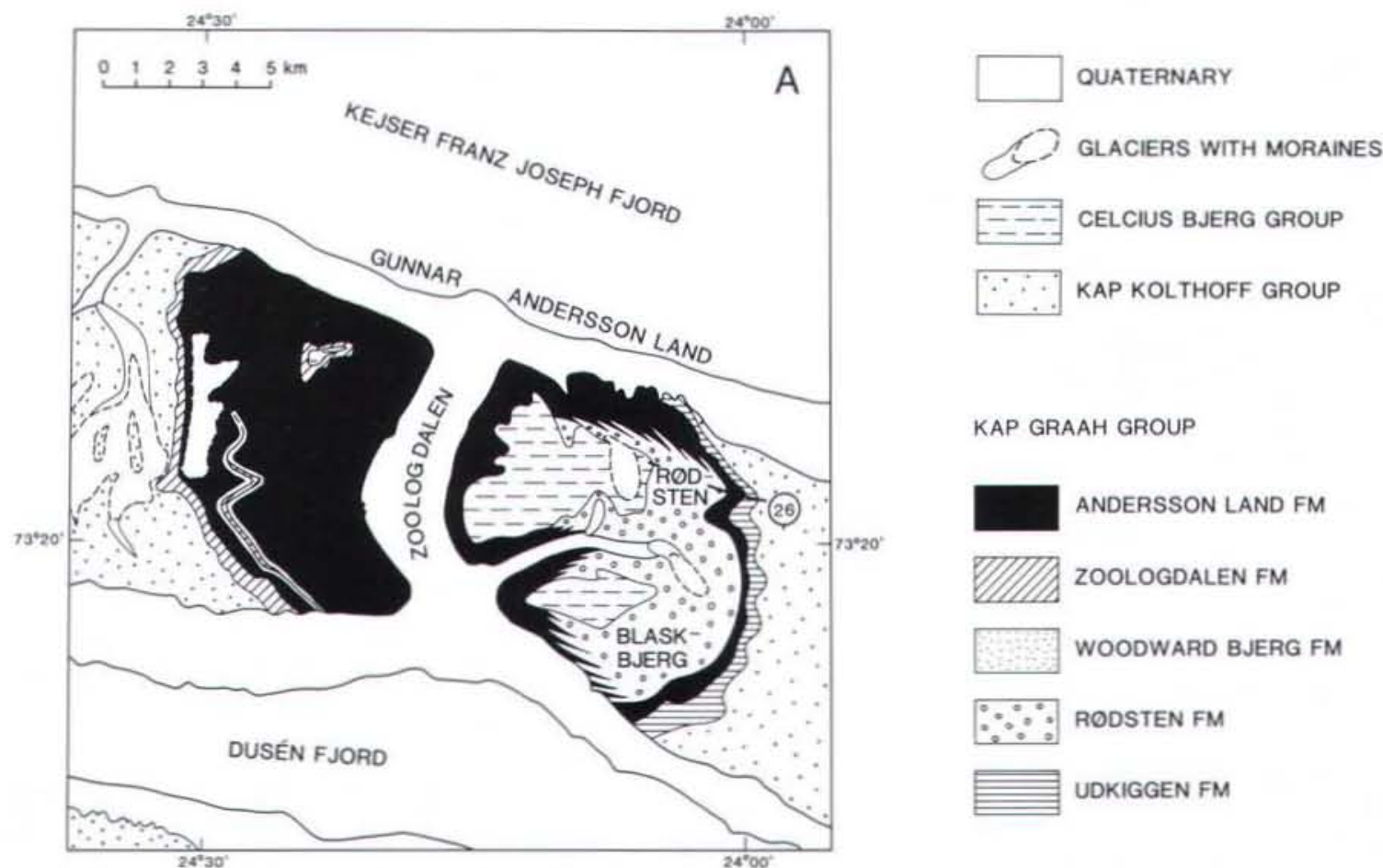

KAP GRAAH GROUP

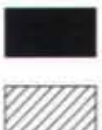

ANDERSSON LAND FM

ZOOLOGDALEN FM

WOODWARD BJERG FM

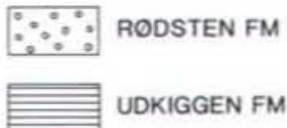

Fig. 61. Geological map of Gauss Halvø (B), Torbern Bergman Bjerg (C), the southeastern part of Strindberg Land (D) and the central (A) and eastern part of Gunnar Andersson Land (E) showing the distribution of the formations of the Kap Graah Group. Locations of sections 19-24 and 26-28 in Figs 62-63 are indicated. 

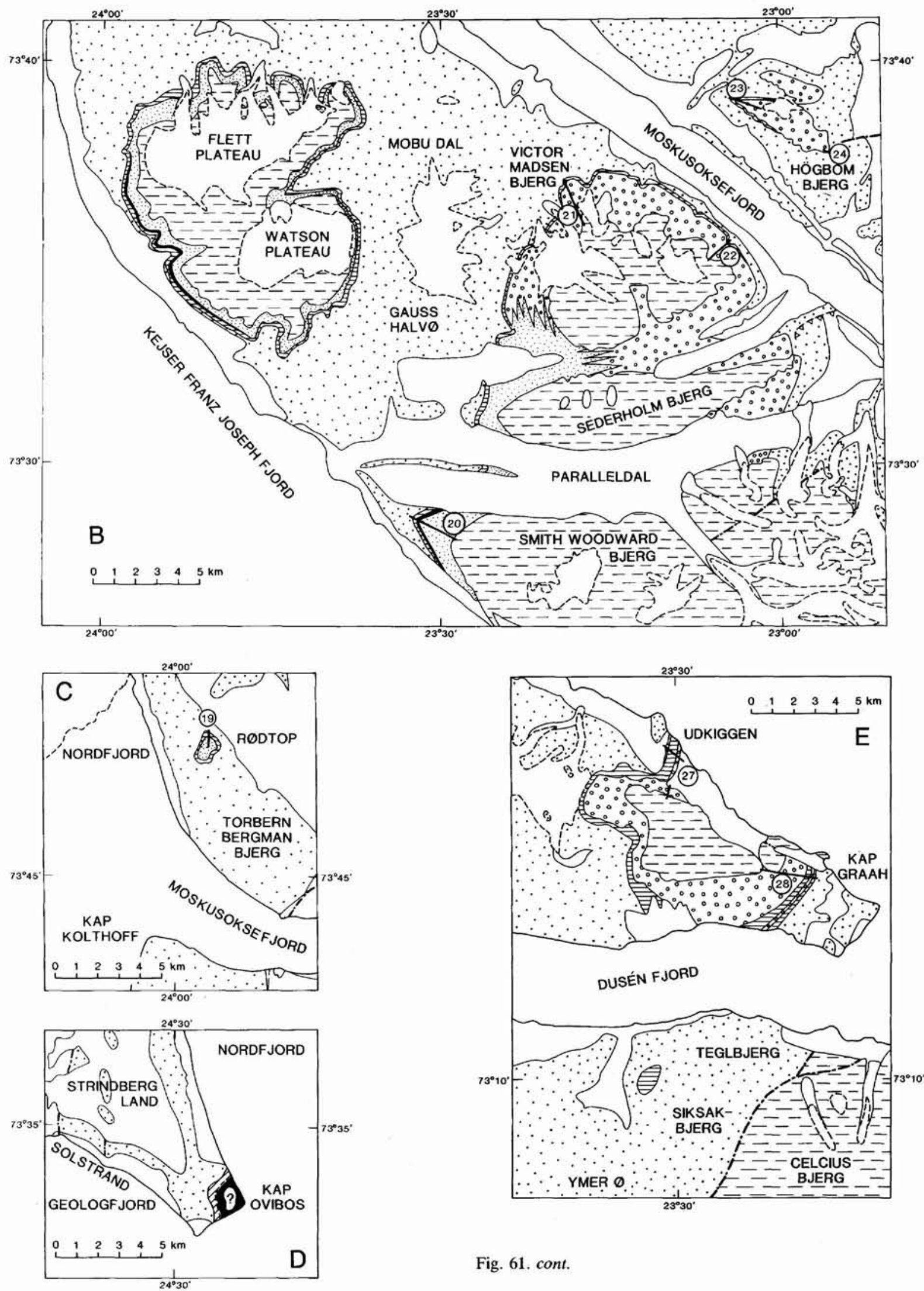

Fig. 61. cont. 
maintaining the main body of the previously defined series/group the boundary delimitation of the Kap Graah Group, as defined by us, differs in detail at several localities (see below).

Name. After the cape in easternmost Gunnar Andersson Land, Ymer $\emptyset$, where a complete succession of the group is exposed (Figs 6, 43, 61).

Type area. Gunnar Andersson Land (Figs 6, 61).

Thickness. The maximum thickness of the group has been measured around Zoologdalen in Gunnar Andersson Land, reaching $c .1300 \mathrm{~m}$. The thickness decreases eastwards and northwards. At Kap Graah the group has been measured to $c .1100 \mathrm{~m}$; on Smith Woodward Bjerg $750 \mathrm{~m}$ occurs and on Victor Madsen Bjerg c. $700 \mathrm{~m}$ has been measured (Larsen, 1990c).

Dominant lithology. The group is mainly composed of trough cross-bedded fine and medium-grained red sandstones (Figs 62,63). Locally red and grey conglomerates occur, mainly in the eastern part of the outcrop area. Red and minor amounts of green siltstones commonly occur in the western and central outcrop areas.

Depositional environments and palaeocurrents. The group was deposited by three main types of depositional systems (Olsen, 1993; Olsen \& Larsen, 1993). Firstly terminal distributary fluvial systems drained the borderlands in the east and west, and transported sediments transversely into the basin with a southwards component. Secondly a longitudinal meandering river in the interior of the basin transported sediments towards the south during the main part of the group's history. Finally aeolian sand seas or ergs developed in parts of the basin. Palaeowinds blew from the east.

Boundaries. The red sandstones and conglomerates, and locally red and green siltstones, rest conformably with a sharp contact on grey or yellowish white and locally red sandstones, usually pebbly, of the Kap Kolthoff Group in the entire outcrop area. The group is overlain by red (generally darker but locally lighter)

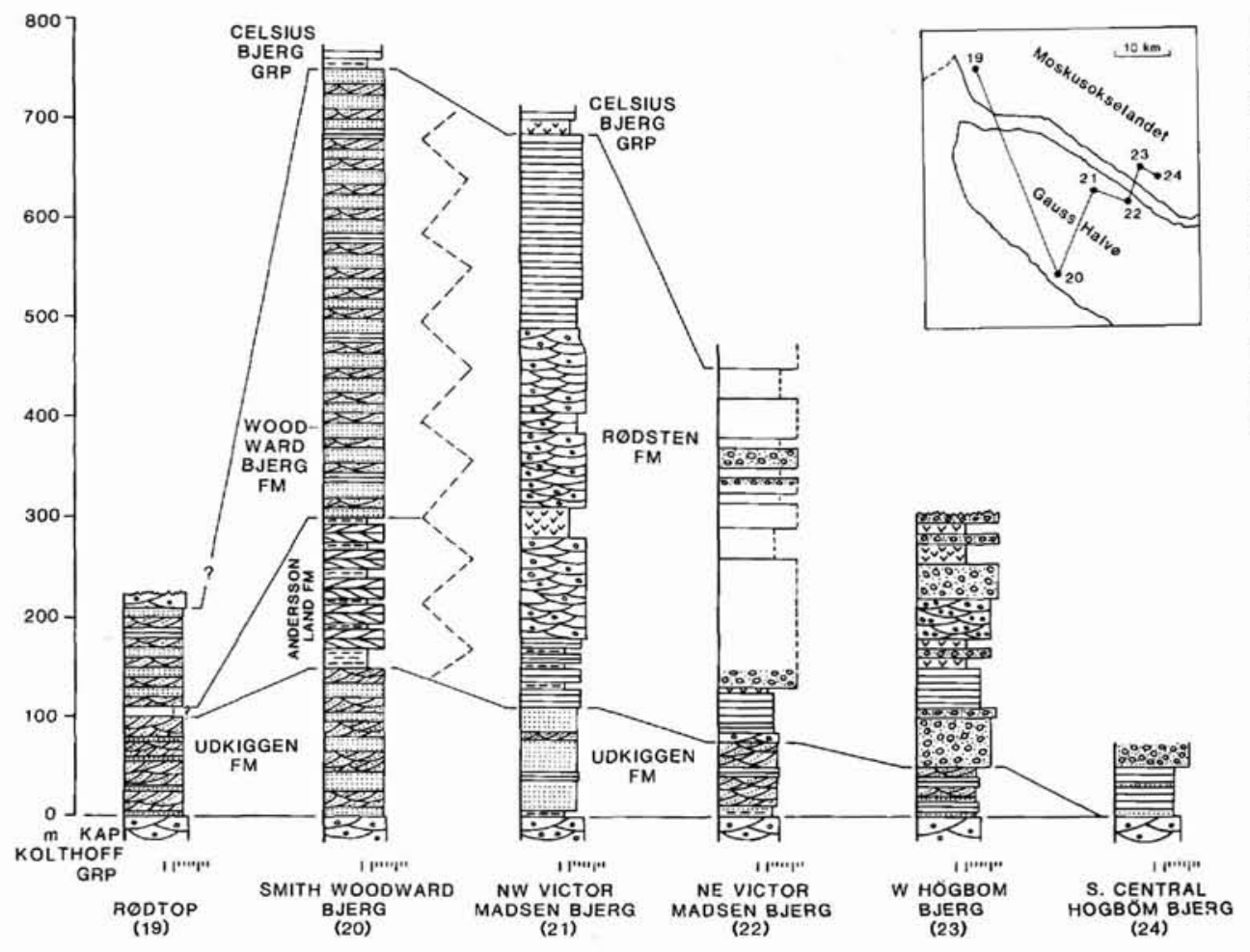

Fig. 62. Generalized sections from the Kap Graah Group in Moskusokselandet and Gauss Halvø. Legend: Plate 2. Section 20 is the type section for the Woodward Bjerg Formation. For locations see also Fig. 61 . 
siltstones and sandstones of the Agda Dal Formation of the Celsius Bjerg Group. This boundary is locally developed as an angular unconformity.

The positions of boundaries, as defined by us, differ at several localities from those described by previous authors. The lower boundary at the type section, Kap Graah (Fig. 61), is defined as the base of the brick red pebble free Udkiggen Formation (Kap Graah Group) resting on red pebbly sandstones of the Teglbjerg Member (Figs 42, 43; Sofia Sund Formation, Kap Kolthoff Group). This is in contrast to Nicholson \& Friend (1976, fig. 15), who placed the boundary c. $400 \mathrm{~m}$ lower, at the base of a volcanic unit (their 'volcanic division'), now regarded as part of the Kap Kolthoff Group. Bütler (1955, fig. 10) placed the base of the group on top of the volcanic unit, where a red pebbly sandstone occurs, now referred to as the Teglbjerg Member (Sofia Sund Formation, Kap Kolthoff Group; Figs 42, 43, Table 1).

Further west the lower boundary is defined as the base of the red pebble free sandstones of the Udkiggen Formation overlying pebbly sandstones of the Sofia Sund Formation, which are either white (Udkiggen; Fig. 64), dark grey (Rødsten; Fig. 72) or red (Blaskbjerg). Nicholson \& Friend (1976, p. 46) placed the boundary, exposed in the coastline on northern Udkiggen, at the base of the rhyolite $c .600 \mathrm{~m}$ below the boundary as defined by us. At southern Udkiggen they placed, however, the boundary as we do at the base of the Udkiggen Formation (Nicholson \& Friend, 1976, fig. 19).

West of Zoologdalen (Fig. 71) and in Strindberg Land (Fig. 61) the lower boundary is defined by an upward change from grey or yellowish white (Strindberg Land) pebbly sandstones of the Sofia Sund Formation to alternating red, green and grey siltstones and sandstones of the Zoologdalen Formation.

In western Gauss Halvø and on Rødtop (Figs 61, 79), Moskusokselandet, the lower boundary is defined as the base of the resistant red Udkiggen Formation resting on white or grey, recessive pebbly sandstones of the Sofia Sund Formation. This is in agreement with Bütler (1959) and Nicholson \& Friend (1976) except for Smith Woodward Bjerg (Fig. 78). At this locality the previous authors placed the boundary several hundred metres lower in the succession, at the base of the Watson Plateau Member (Sofia Sund Formation, Kap Kolthoff Group; Fig. 39, Table 1).

At Victor Madsen Bjerg (Fig. 65) the lower boundary is defined as the base of the red pebble free sandstones of the Udkiggen Formation resting on grey (NW part of mountain) or red (E part of mountain) pebbly sandstones of the Sofia Sund Formation. Bütler (1959, fig. $15)$ placed the lower boundary a few hundred metres lower, at the base of the underlying grey pebbly sandstone unit forming part of the Sofia Sund Formation, exposed on NW Victor Madsen Bjerg.

At western Högbom Bjerg the lower boundary is defined at the base of the pebble free red sandstones of the Udkiggen Formation resting on red pebbly sandstones of the Sofia Sund Formation. On south central Högbom Bjerg the lower boundary is defined as the base of a red flat laminated pebble free sandstone unit (getting conglomeratic higher up), the Rødsten Formation, resting on red cross-bedded pebbly sandstones of the Sofia Sund Formation. The boundary at Högbom Bjerg is difficult to recognize from a distance. Bütler (1959, fig. 22, pl. 3) and Nicholson \& Friend (1976, p. 77) placed the boundary on Högbom Bjerg at an angular unconformity occurring internally in the Sofia Sund Formation several hundred metres below the boundary, as defined by us (Larsen, 1990d).

In Moskusokselandet between Rødtop and Högbom Bjerg the group is absent (Fig. 61). This is in contrast to Bütler (1959, pl. 3) and Nicholson \& Friend (1976, p. 83), who considered the Watson Plateau Member (Sofia Sund Formation; Fig. 38) as the basal part of the Kap Graah Group.

Bütler (1955, fig. 15) and Nicholson \& Friend (1976, fig. 2) considered several red and grey outliers on Ymer $\emptyset$, Geographical Society $\emptyset$ and Traill $\emptyset$ as part of the Kap Graah Group. These outliers are now considered as part of the Sofia Sund Formation.

At Celsius Bjerg (Ymer $\emptyset$ ) and Rudbeck Bjerg (Geographical Society $\varnothing$ ) Bütler (1955, fig. 16) and Nicholson \& Friend (1976, fig. 24, p. 52) defined the lower boundary of the unit where red pebbly sandstones rest on grey pebbly sandstones. These rocks are now regarded partly as constituents of the Sofia Sund Formation and partly as constituents of the Celsius Bjerg Group (Fig. 6, Table 1; Larsen, 1990a).

The upper boundary of the Kap Graah Group is exposed in central Gauss Halvø and on Gunnar Andersson Land (Fig. 61). On Victor Madsen Bjerg (Fig. 65) this boundary is defined by an upward abrupt transition from recessive red sandstones of the Rødsten Formation to resistant darker red conglomerates (east) and sandstones (west) of the Agda Dal Formation (Celsius Bjerg Group). A change in palaeocurrent directions from SSW in the Rødsten Formation to NNW in the Agda Dal Formation is also evident (Olsen, 1993).

At Sederholm Bjerg the Group is unconformably overlain by the Agda Dal Formation. This angular unconformity was also suggested as the top of the unit by Bütler (1959, fig. 18) but redefined by Nicholson \& Friend $(1976$, figs 38,39$)$ as the base of the 'upper Kap Graah Group' (now recognized as Agda Dal and Elsa 
Fig. 63. Generalized sections from the Kap Graah Group in Gunnar Andersson Land. Legend: Plate 2. Section 25 is type section for the Zoologdalen Formation and Andersson Land Formation. Section 26 is type section for the Rødsten Formation. Section 27 is type section for the Udkiggen Formation. For locations see also Figs $61,81$.

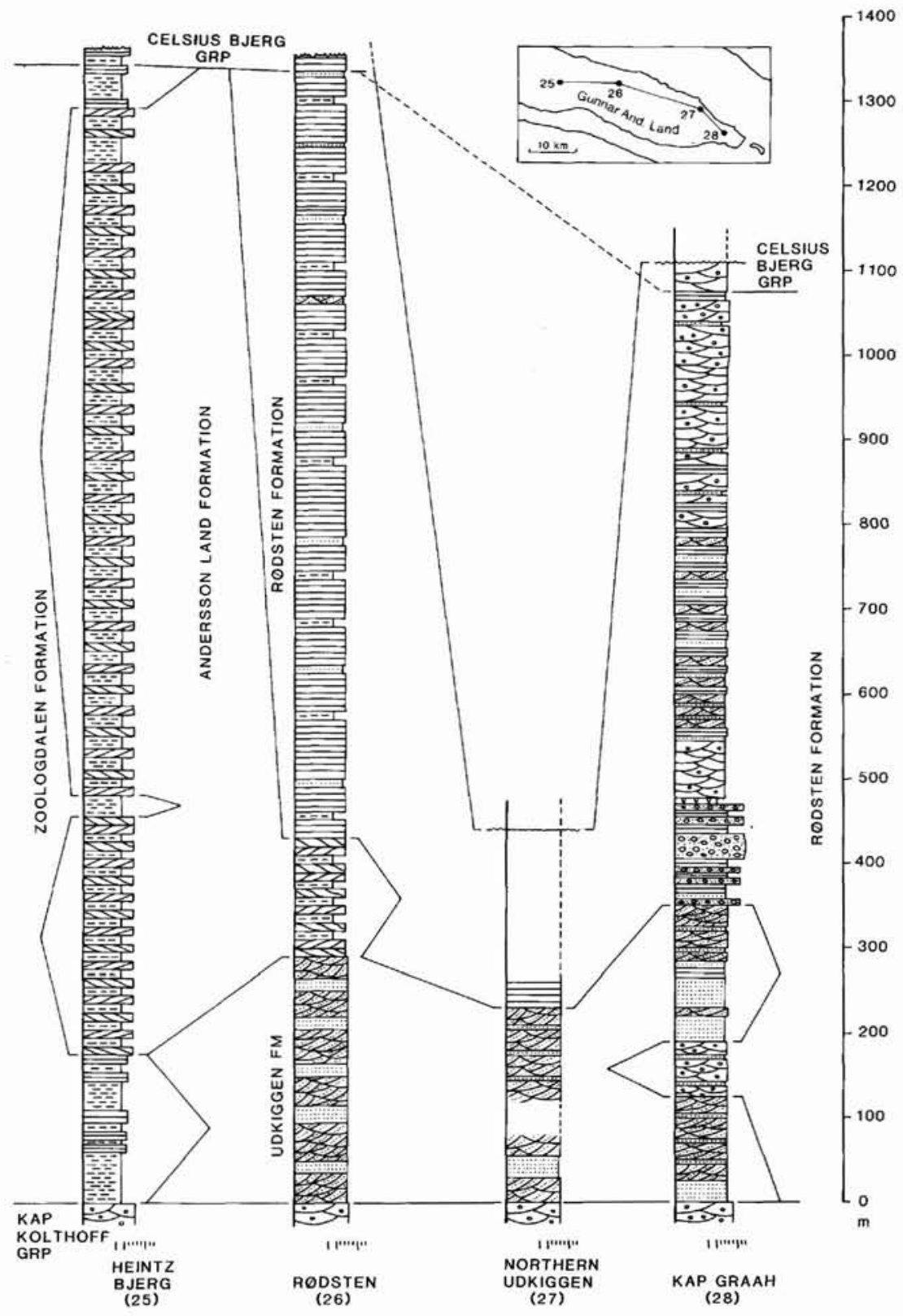

Dal Formations, Celsius Bjerg Group).

At Smith Woodward Bjerg (Fig. 78) the top of the group is defined by the top of the red sandstones of the Woodward Bjerg Formation overlain by the interbedded red siltstones and sandstones of the Agda Dal Formation.

In central Gunnar Andersson Land, at Rødsten (Fig. 72), the upper boundary is defined as the top of the interbedded red sandstone and siltstone unit of the
Rødsten Formation overlain by lighter red or reddish grey sandstones and siltstones of the Agda Dal Formation. Also a change in palaeocurrent directions is involved, being directed towards the SW in the Rødsten Formation (Kap Graah Group) and towards the NNE in the Agda Dal Formation (Celsius Bjerg Group) (Olsen, 1993; Olsen \& Larsen, 1993).

On Heintz Bjerg, in Gunnar Andersson Land (Fig. 81 ), the upper boundary is defined by the upward tran- 
Fig. 64. Northern part of the mountain Udkiggen, Gunnar Andersson Land, facing Kejser Franz Joseph Fjord. The coastal exposure in the lower part of the photograph is type section 27 (Figs 61, 63) of the Udkiggen Formation (U). (SS) Sofia Sund Formation, (R) Rødsten Formation. (AGD) Agda Dal Formation and (ED) Elsa Dal Formation are also seen. Notice the presence of a coast parallel fault. Thickness of the Udkiggen Formation at this locality is $c .230 \mathrm{~m}$.

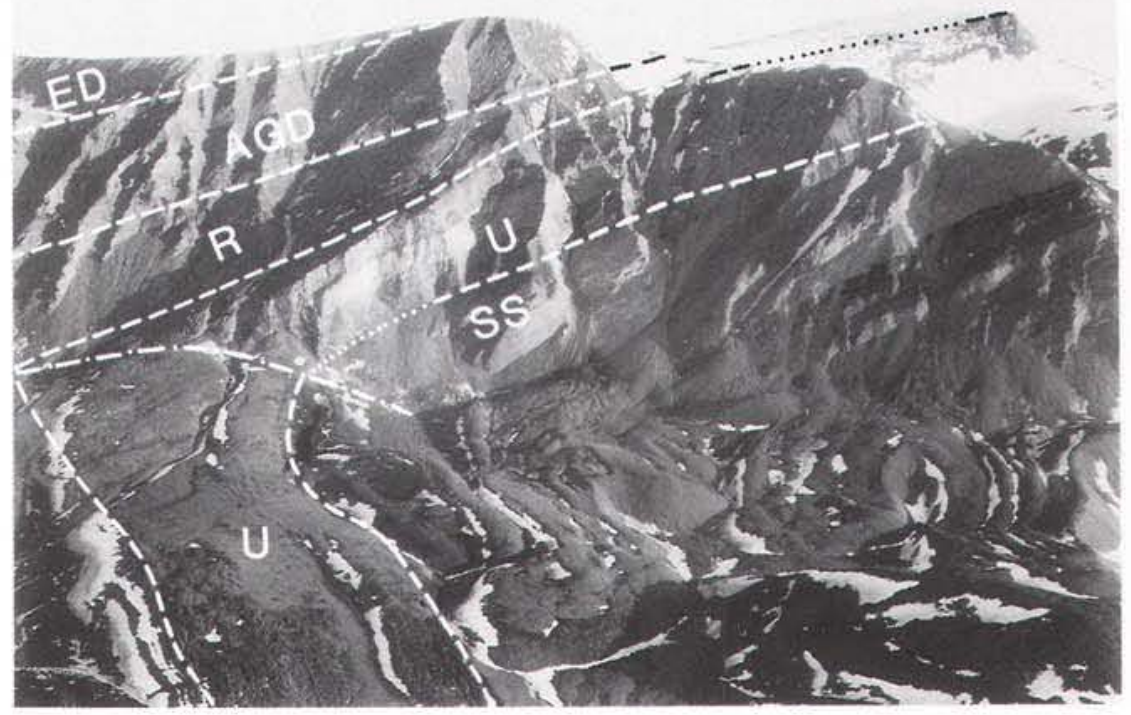

sition from mainly red siltstones of the Zoologdalen Formation (Kap Graah Group) to mainly lighter red siltstones of the Agda Dal Formation. This change is associated with a change in palaeocurrent directions from SSW in the Zoologdalen Formation to NNE in the Agda Dal Formation (Olsen, 1993; Olsen \& Larsen. 1993).
Distribution. The group crops out in southern and eastern Hudson Land, in Gauss Halvø and in Gunnar Andersson Land (Figs 6, 61). In contrast to Koch \& Haller (1971), Nicholson \& Friend (1976) and Friend et al. (1983) no rocks on Celsius Bjerg are considered part of the Kap Graah Group by us. It may be present on Geographical Society $\varnothing$ south of Rudbeck Bjerg and on

Fig. 65. Northwestern part of the mountain Victor Madsen Bjerg, immediately SE of Fig. 59. Section 21 of the Kap Graah Group was measured above the Kap Kolthoff Group (KK GRP) along the mountain ridge in the middle of the photograph (Figs 62, 63). This is the reference section of the Udkiggen Formation (U) and Rødsten Formation (R). The Celsius Bjerg Group (CB GRP) tops the mountain. Section 29 (Figs 85, 89) was measured immediately above section 21 along the mountain ridge. Elevation above sea level of mountain ridge in the middle of the photograph is c. $1200 \mathrm{~m}$.

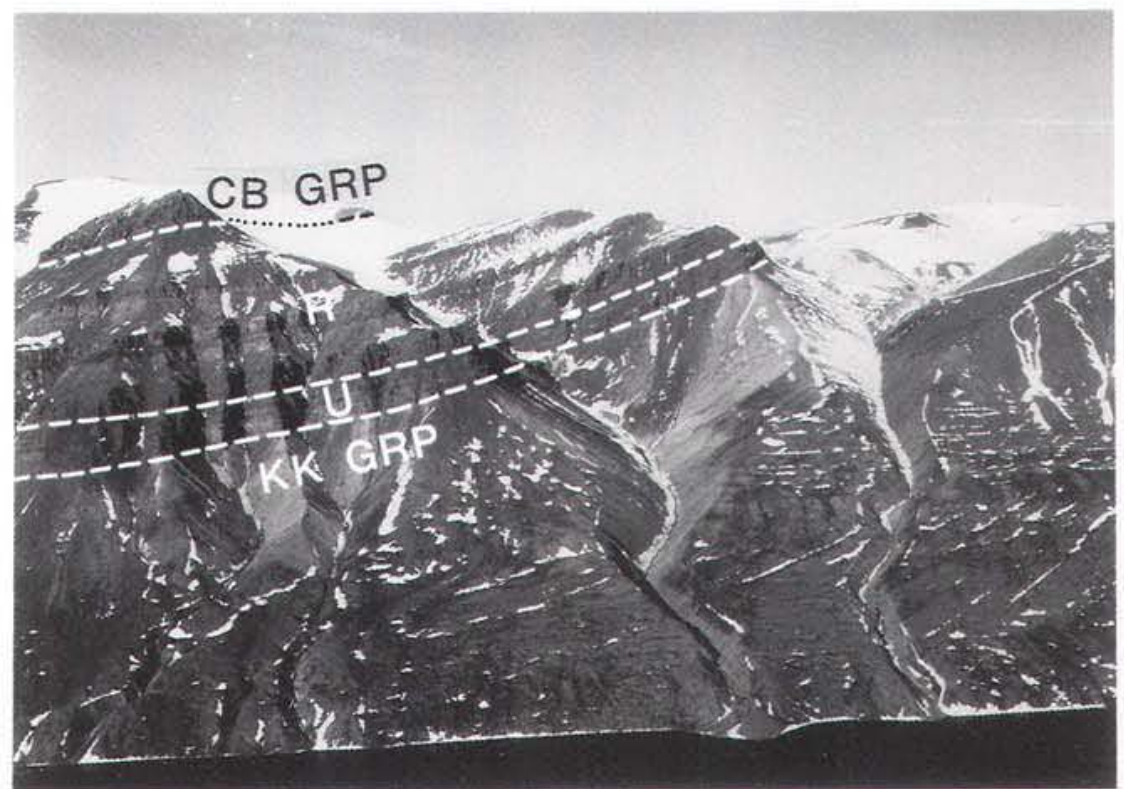



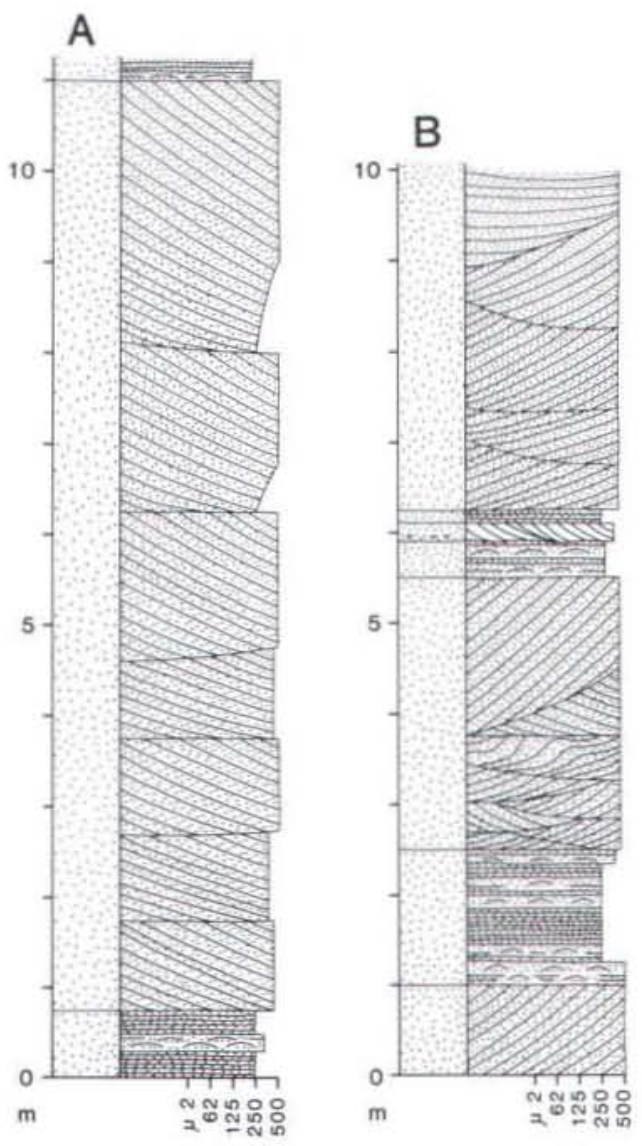

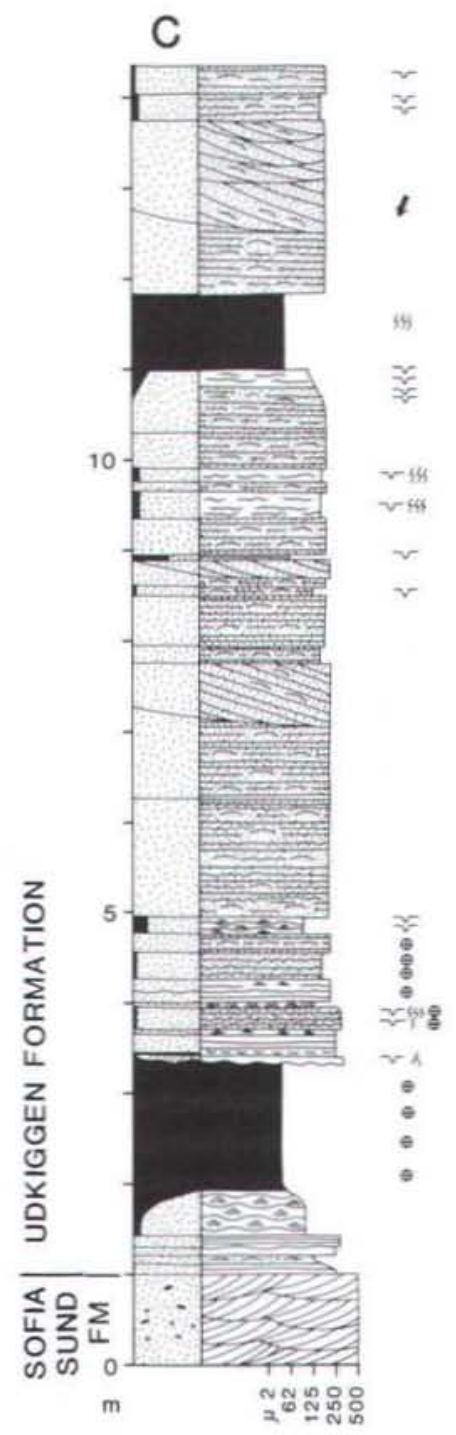

Fig. 66. Facies logs from the Udkiggen Formation showing the dominance of acolian sandstones. A is from type section 27 (Figs 61, 63) in the coastal exposures of northern Udkiggen. It was measured c. $200 \mathrm{~m}$ above the base of the formation. B is from reference section 28 (Figs 61, 63) at Kap Graah, c. $300 \mathrm{~m}$ above the contact to the Kap Kolthoff Group. C is measured at the lower boundary to the Sofia Sund Formation (Kap Kolthoff Group) in reference section 21 (Figs 61, 62), NW Victor Madsen Bjerg, Legend: Plate 2.
Traill Ø (Larsen, 1990a), but has not been examined by us in these areas.

Geological age. Numerous finds of fossil fish suggest a Late Devonian (Famennian) age of this group (Friend $e t$ al., 1983).

Subdivisions. The group, although already established in 1976 (Nicholson \& Friend, 1976), has never been formally subdivided. It is now subdivided into five formations: Udkiggen Formation, Zoologdalen Formation, Rødsten Formation, Woodward Bjerg Formation and Andersson Land Formation (Plate 1). These will be described in turn below.

\section{Udkiggen Formation new formation}

History. This formation was included in Kulling's (1931, fig. 4) 'midmost red sandstone series' and mapped by Bütler $(1935,1959,1961)$ as part of his 'Kap Graah Series'. It was indicated as part of the 'Cape Graah Series' on the map of Koch \& Haller (1971). It was included in the Kap Graah Group by Nicholson \& Friend (1976), and the informal 'red arkose division' and 'division 1' were assigned to it at the Kap Graah and Watson Plateau localities, respectively.

Name. After the mountain, Udkiggen west of Kap Graah on Gunnar Andersson Land (Figs 61, 64). 
Type and reference sections. The type section is northern Udkiggen (section 27, Figs 61, 63, 64). Reference sections are located at several localities in Hudson Land, Gauss Halvo and Gunnar Andersson Land (sections 19-23, Figs $61,62,65,78,79$ and sections $26 \& 28$, Figs $61,63,72$ ). Detailed reference sections are from northern Udkiggen (Figs 66A, 67A), Kap Graah (Figs 66B, 67B) and Victor Madsen Bjerg (Figs 66C).

Thickness. The thickness of the formation in Gunnar Andersson Land is c. $350 \mathrm{~m}$ at Kap Graah (including an interfingering wedge of the Rødsten Formation) and $c$. $250 \mathrm{~m}$ at northern Udkiggen. At Rødtop in Moskusokselandet the formation is $c .100 \mathrm{~m}$ thick. At Watson Plateau in western Gauss Halvø the unit measures $c$. $200 \mathrm{~m}$ decreasing towards the east, i.e. c. $150 \mathrm{~m}$ at Smith Woodward Bjerg and $c .100 \mathrm{~m}$ at Victor Madsen Bjerg (Larsen, 1990a).

Lithology and sedimentary structures. The formation is composed of fine to medium-grained red sandstones with locally grey sandstone interbeds. Coarse-grained sandstone beds and siltstones also rarely occur. Trough cross-bedding dominates this formation with important contributions (locally dominant) of flat lamination and irregular lamination. Locally very large tabular crosssets with trough cross-bedded intra sets occur. Intraand extraformational clasts are extremely rare. The formation is characterized by the abundance of large-scale trough cross-sets more than $1 \mathrm{~m}$ in thickness.

Depositional environments and palaeocurrents. The sediments of this formation are at most localities almost entirely aeolian (Olsen, 1993; Olsen \& Larsen, 1993) (Figs 68, 69). They are dominated by trough crossbedding of barchanoid dune origin and winds blew from the east (Olsen, 1993). Individual trough sets commonly form part of up to $20 \mathrm{~m}$ thick composite sets of tabular appearance (Fig. 69) interpreted as composite dune or draa deposits. The flat and irregular lamination was formed as sandsheets or interdunes.

Boundaries. The lower boundary of the Udkiggen Formation is defined by a change from grey, white or locally, at Högbom Bjerg, Blaskbjerg and Kap Graah, red pebbly sandstones of the Sofia Sund Formation to red, pebble free sandstones of the Udkiggen Formation (Figs 61, 64, 65, 72, 79). The upper boundary is defined on Rødtop (Fig. 79), in western and southern Gauss Halvø and central Gunnar Andersson Land (Fig. 72) by an abrupt contact to interbedded red, grey and minor green siltstones and sandstones of the Andersson Land Formation, and is commonly recognized by the change from resistant rocks of the Udkiggen Formation to recessive rocks of the Andersson Land Formation. In eastern Gunnar Andersson Land the Udkiggen Forma-
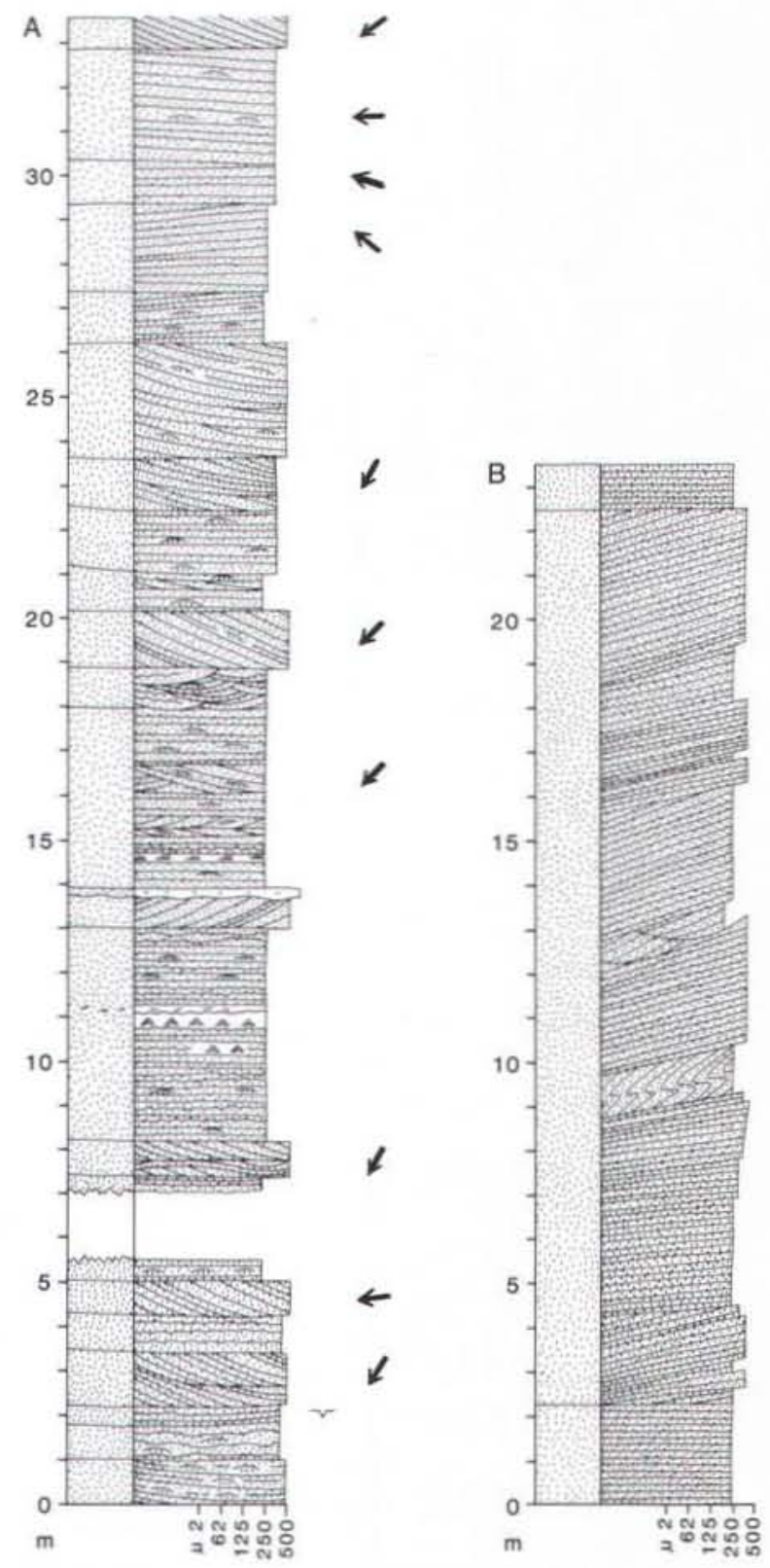

Fig. 67. Facies logs from the Udkiggen Formation. A shows the dominance of flat-bedded aeolian sandstones. Subaqueous deposits are only represented by cross-laminations, a thin intraclast-rich bed and a massive bedded layer. It is measured in type section 27 (Figs 61, 63) at northern Udkiggen, c. $30-60 \mathrm{~m}$ above the base. B shows a single large aeolian cross-set with minor intrasets. It is measured c. $75-100 \mathrm{~m}$ above the base of the formation at reference section 28 (Figs 61, 63) at Kap Graah. Notice the different scale in both logs compared to Fig. 66. Legend: Plate 2. 


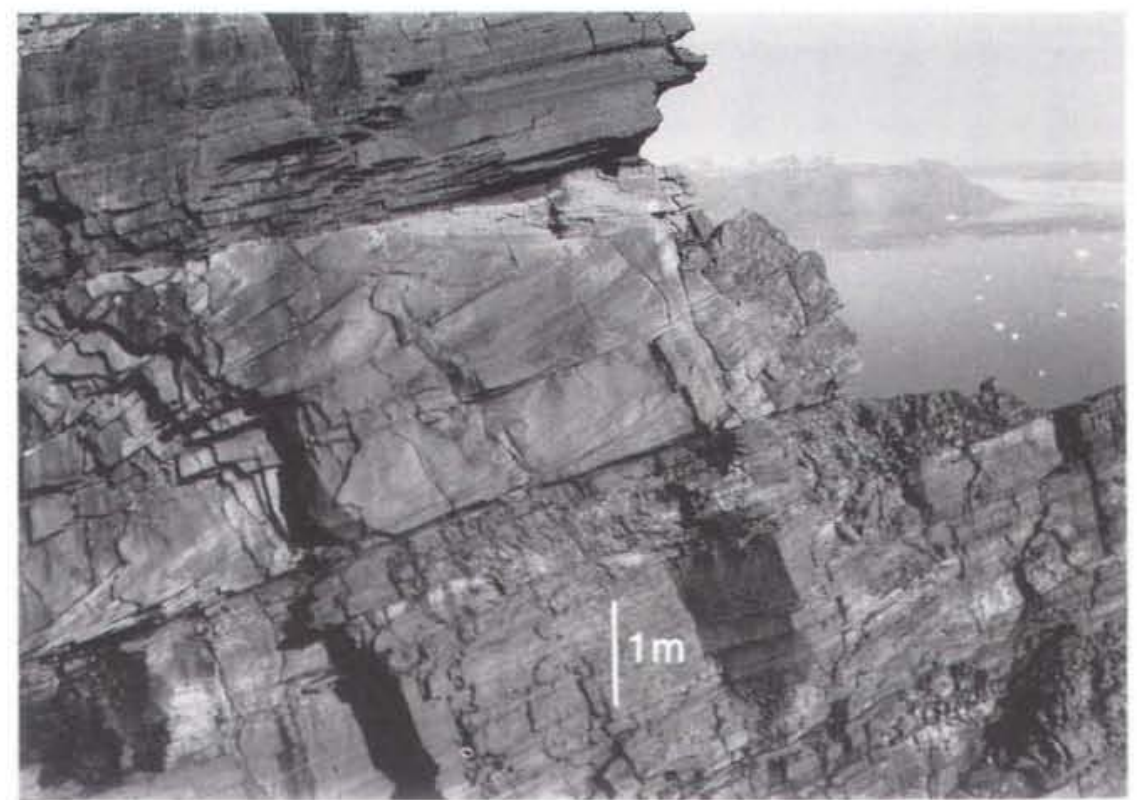

Fig. 68. Aeolian sandstones of the Udkiggen Formation at Rødsten (section 26; Figs 61, 63). In the upper and lower part of the photograph flat-bedding dominates, in the middle part a coset of elongate trough cross-sets is observed. View is towards NNE. Strindberg Land and the Waltershausen Gletscher is seen in the background.

tion interdigitates with grey and red pebbly sandstones of the Rødsten Formation (Figs 43, 61, 64, 69). On Högbom Bjerg the formation is overlain by red pebbly sandstones and conglomerates of the Rødsten Formation. On NW Victor Madsen Bjerg it is overlain by red interbedded sandstones and siltstones of the Rødsten Formation (Fig. 65).

Distribution. The formation crops out on Rødtop and
Högbom Bjerg in Hudson Land, in Gauss Halvø, and eastern and central Gunnar Andersson Land (Fig. 61).

Geological age. No fossils have been identified from this formation. Famennian fossil fish have, however, been found (Friend et al., 1983) in both the underlying Sofia Sund Formation and the overlying Rødsten Formation, and a Famennian age (Late Devonian) is thus also assigned to the Udkiggen Formation.

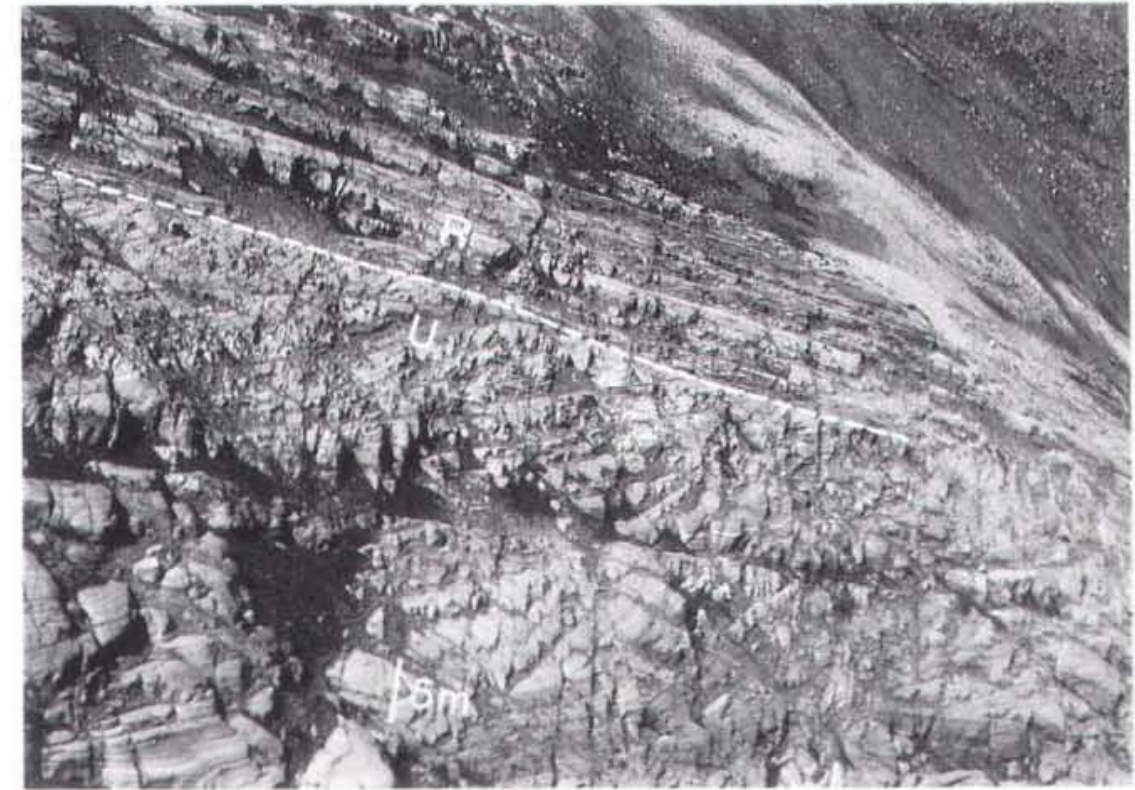

Fig. 69. Bedding characteristics of the Udkiggen Formation (U) and the Rødsten Formation (R) at Kap Graah (section 28; Figs $61,63)$. The boundary is $c .125 \mathrm{~m}$ above the base of the Kap Graah Group. Notice the two up to 20 $\mathrm{m}$ thick composite cross-sets of tabular appearance in the Udkiggen Formation. They were formed by large compound dunes/draas. 


\section{Zoologdalen Formation} new formation

History. The sediments of this formation were mapped by Bũtler $(1935 a, 1959,1961)$ as part of his 'Kap Graah Series' and indicated on the map of Koch \& Haller (1971) as part of the 'Cape Graah Series' on Gunnar Andersson Land and as part of the 'Cape Kolthoff Series' on Strindberg Land at Kap Ovibos. The formation exposed in Gunnar Andersson Land was ascribed to the Kap Graah Group by Nicholson \& Friend (1976). They placed the Strindberg Land sediments in the 'Kap Kolthoff Supergroup' but later in Friend et al. (1983, fig. 30) they described the sediments as questionable Kap Graah Group deposits.

Type and reference sections. The type section is the mountain Heintz Bjerg west of Zoologdalen (section 25 , Figs $63,71,81)$. The detailed reference section is also from this locality (Fig. 70).

Lithology and sedimentary structures. The formation is dominated by red and green siltstones. Grey, red and green sandstone beds locally form up to $60 \%$ of the formation (Fig. 70). The sandstone beds are generally less than $1 \mathrm{~m}$ thick, but may reach up to $3.5 \mathrm{~m}$ in thickness. The siltstones are parallel laminated and rarely cross-laminated. Calcrete horizons are commonly observed. Bioturbation is common. The sandstones are very fine to fine-grained and rarely medium-grained. Sedimentary structures include trough cross-bedding, parallel lamination and cross-lamination. Rootlet impressions and desiccation cracks are common at the top of sandstone beds.

Depositional environment and palaeocurrents. The formation was deposited by ephemeral streams and in associated extensive flood basins. Palaeocurrents are southeastwards and the formation probably represents a terminal fan system draining the highlands west of the basin (Olsen, 1993; Olsen \& Larsen, 1993).

Thickness. The formation is developed as wedges as observed on Heintz Bjerg, where the most complete succession is preserved. The cumulative thickness of these wedges reaches $250 \mathrm{~m}$.

Boundaries. In Strindberg Land (Fig. 61) and Gunnar Andersson Land (Figs 61, 71) the lower boundary is defined by an upward abrupt change from grey or yellowish white pebbly sandstones of the Sofia Sund Formation to red, green and grey siltstones and sandstones of the Zoologdalen Formation. The formation interdig- itates with the Andersson Land Formation in Gunnar Andersson Land (Fig. 61) and is recognized by the absence of metre-thick tabular bodies of mediumgrained sandstones, characteristic of the Andersson Land Formation. The Zoologdalen Formation is overlain by the Agda Dal Formation in Gunnar Andersson Land (Figs 61, 71, 81). The transition is not associated

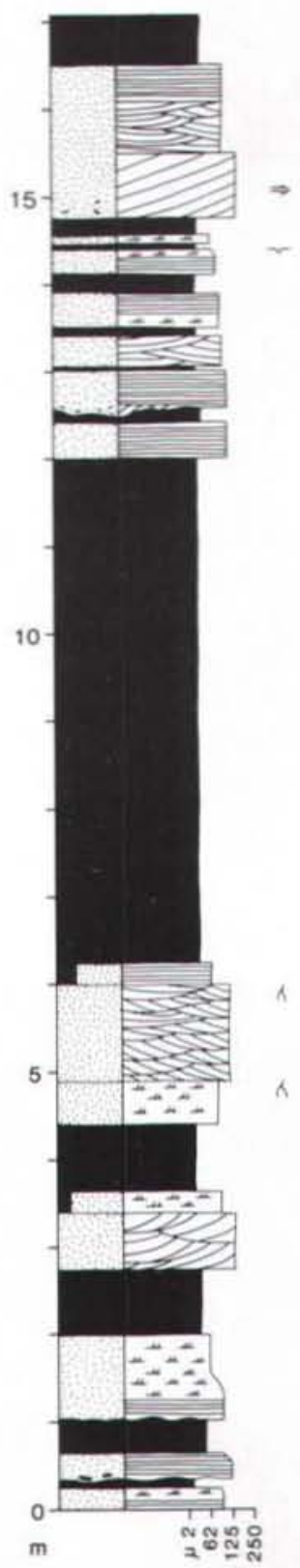

Fig. 70. Facies log from the Zoologdalen Formation measured c. $160 \mathrm{~m}$ above the base of the formation in type section 25 (Figs 63, 81), west of Zoologdalen in Gunnar Andersson Land. Legend: Plate 2. 


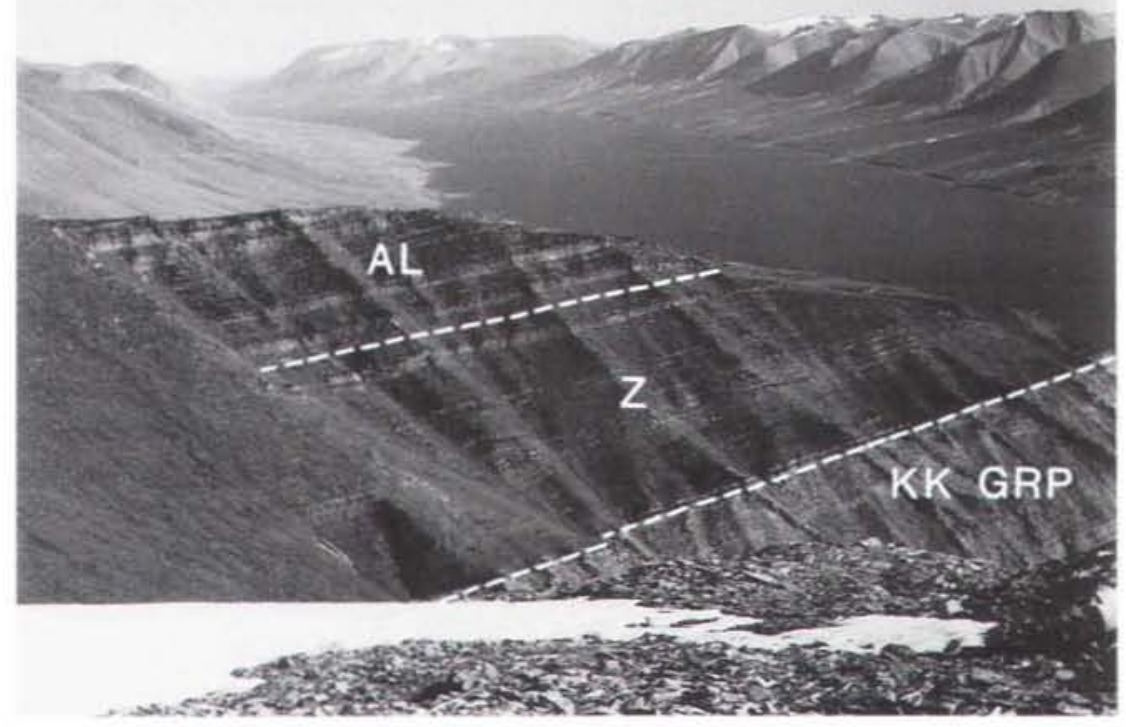

Fig. 71. The lower part of section 25 (Figs 63, 81) at the mountain immediately west of Zoologdalen. This is the type section of the Zoologdalen Formation and Andersson Land Formation. The resistant sandstones of the Kap Kolthoff Group (KK GRP) are overlain by the mudstone dominated Zoologdalen Formation. The thickness of this lower unit of the Zoologdalen Formation is c. $175 \mathrm{~m}$. The Andersson Land Formation is characterized by tabular sandstone bodies alternating with mudstones. The view is towards SE, the Dusén Fjord is seen in the background.

with a change in sediment type. It is, however, recognized by a slight change of the siltstones to a lighter red colour in the Agda Dal Formation. This change is associated with a change in palaeocurrent directions from $\mathrm{SE}$ in the Zoologdalen Formation to NNE in the Agda Dal Formation (Olsen, 1993; Olsen \& Larsen, in press). The top of the Zoologdalen Formation is not exposed in Strindberg Land (Fig. 61).
Distribution. The formation crops out only at Kap Ovibos in Strindberg Land and west of Zoologdalen in Gunnar Andersson Land (Fig. 61).

Geological age. West of Zoologdalen in Gunnar Andersson Land the formation is rich in fossil fish, e.g. Phyllolepis (Nicholson \& Friend, 1976, p. 47) indicating a Famennian age (Friend et al., 1983; Jarvik, 1961).

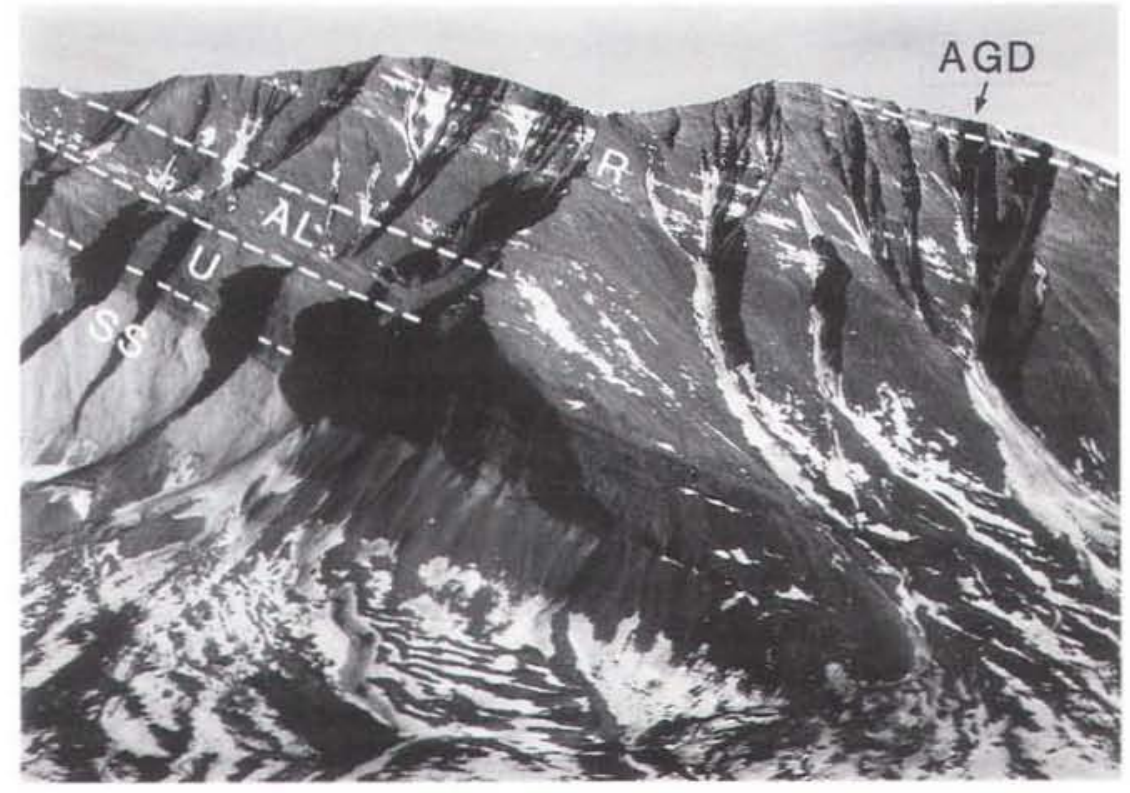

Fig. 72. The mountain Rødsten in Gunnar Andersson Land, facing Kejser Franz Joseph Fjord. Along the mountain ridge, section 26 (Figs 61, 63) was measured through the Kap Graah Group. The section is type section of the Rødsten Formation (R) and reference section of the Udkiggen Formation (U) and Andersson Land Formation (AL). The Kap Graah Group overlies the Sofia Sund Formation (SS) of the Kap Kolthoff Group and is itself overlain by the Agda Dal Formation (AGD) of the Celsius Bjerg Group. Thickness of the Udkiggen Formation is c. $300 \mathrm{~m}$. 


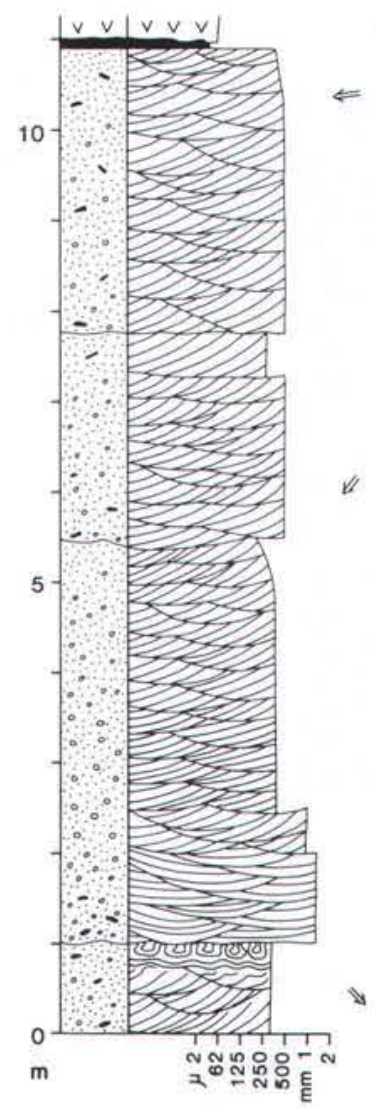

Fig. 73. Facies $\log$ from the Rødsten Formation at reference section 21 (Figs 61,62 ) on NW Victor Madsen Bjerg. The log was measured c. $175 \mathrm{~m}$ above the base of the formation. Legend: Plate 2.

\section{Rødsten Formation}

new formation

History. This formation was included in Kulling's (1930, 1931) 'midmost red sandstone series'. It was included in the 'Kap Graah Series' by Bütler $(1935,1959,1961)$ and indicated as part of the 'Cape Graah Series' on the map of Koch \& Haller (1971). Nicholson \& Friend (1976) included the formation in the Kap Graah Group, without assigning any formal formation name to it. The informal 'upper pebbly sandstone division' and 'greenspotted and grey sandstone division' at Kap Graah (Nicholson \& Friend, 1976, fig. 15) are included in the formation.

Name. After the mountain Rødsten in northern Gunnar Andersson Land (Fig. 61).

Type and reference sections. The type section is Rødsten (section 26, Figs 61, 63, 72). Reference sections are
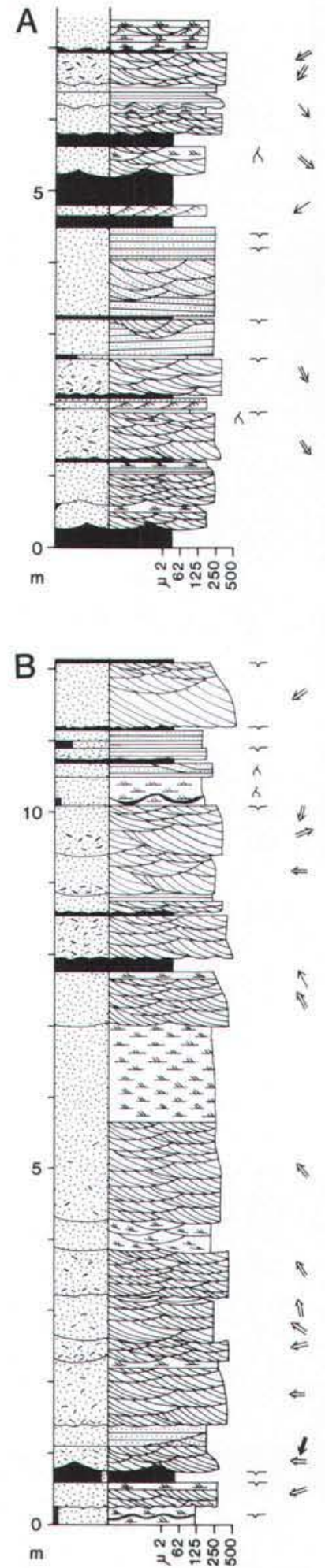

Fig. 74. Facies logs illustrating interbedded sandstones and siltstones of the Rødsten Formation. A is from type section 26 (Figs 61, 63) at the mountain Rødsten and B is from the mountain Blaskbjerg immediately south of Rødsten. Both logs are measured c. $250 \mathrm{~m}$ above the base of the formation. Legend: Plate 2. 


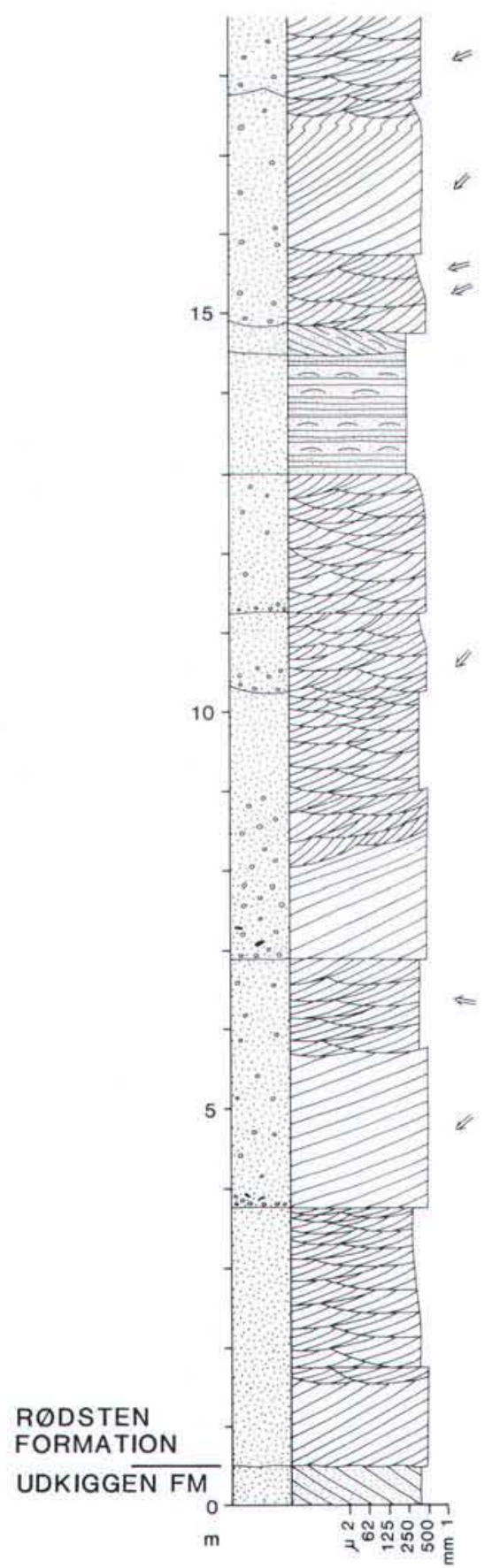

Fig. 75. Facies $\log$ from the Rødsten Formation at reference section 28 (Figs 61, 63) at Kap Graah. The $\log$ was measured $c$. $125 \mathrm{~m}$ above the base of the Kap Graah Group. The dominance of trough cross-bedded pebbly sandstones is typical of the formation at this locality. Legend: Plate 2. from several localities in Moskusokselandet, Gauss Halvø and Gunnar Andersson Land (sections 21-24, Figs 61, 62 and section 28. Figs 61, 63). Detailed reference sections are from Victor Madsen Bjerg (Fig. 73), Rødsten (Fig. 74A), Blaskbjerg (Fig. 74B) and Kap Graah (Figs 75, 76).

Thickness. The formation is $c$. $900 \mathrm{~m}$ thick at Rødsten and $725 \mathrm{~m}$ plus $70 \mathrm{~m}$ (lower lying wedge) at Kap Graah. In Gauss Halvø at Victor Madsen Bjerg the thickness of the unit has been measured to $375 \mathrm{~m}$ in the east, increasing to $c .575 \mathrm{~m}$ in the west.

Lithology and sedimentary structures. The formation is dominated by medium to coarse-grained red or reddish grey sandstones (Fig. 75). Locally red pebbly conglomerates dominate (Fig. 76). At some localities a high proportion, or the whole formation, is composed of red interbedded fine to medium-grained sandstones and siltstones, dominated by the sandstones (Figs 74, 77) The sandstones are usually trough cross-bedded, locally parallel lamination is an important constituent, whereas cross-lamination is absent to common. In certain intervals trough cross-bedding with translatent strata. characterized by sets $0.5-1 \mathrm{~m}$ thick, is abundant to dominant. The siltstones commonly display desiccation cracks. The conglomerates are dominated by scour and fill structures and parallel lamination. Imbrication is locally well-developed. Basaltic lavas are common in the formation.

Depositional environments and palaeocurrents. The Rødsten Formation was deposited as terminal fans and alluvial fans (Olsen, 1993; Olsen \& Larsen, 1993). Alluvial fans occurred close to the basin margin in the east. The terminal fans occurred further into the basin exhibiting sandy braided stream patterns in their proximal parts and ephemeral streams in their distal parts. Palaeocurrents are westwards and southwestwards indicating draining of the highlands bordering the basin in the east (Olsen, 1993). In the distal part of the system reworking of fluvial sands by aeolian processes was common, though large dunes were rare. In the proximal part of the systems interchannel areas were sometimes dominated by aeolian processes and dune development.

Fig. 76. Facies $\log$ from the Rødsten Formation c. 350-415 m above the base of the Kap Graah Group from reference section 28 (Figs 61, 63) at Kap Graah. The log shows the lower coarsening upward part of a coarsening-to-fining upward sequence, interpreted as an alluvial fan deposit. Legend: Plate 2. 

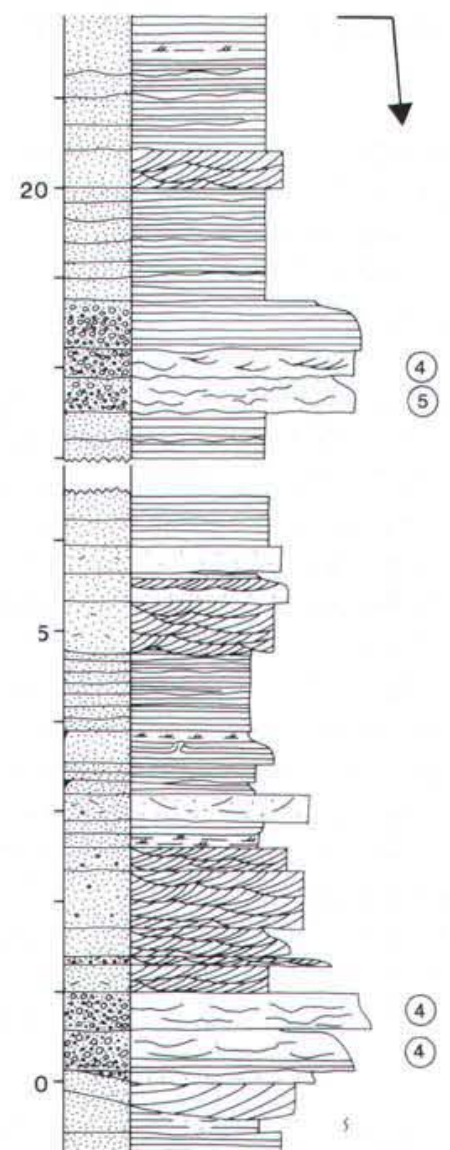

(4)

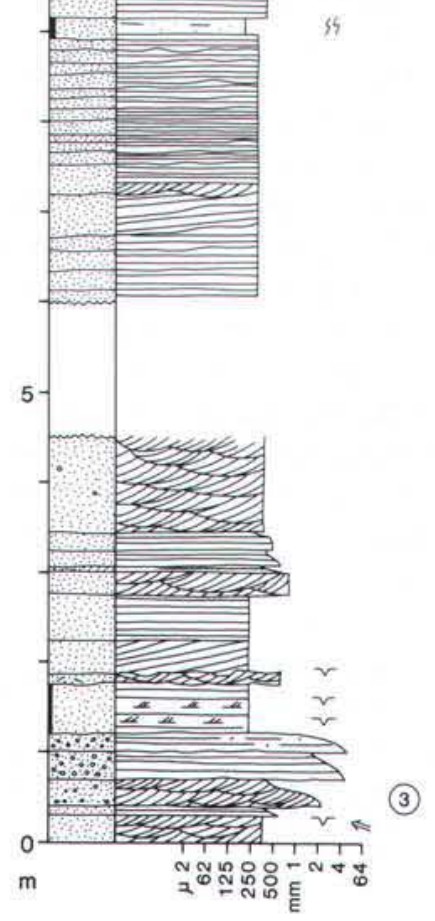

(4)
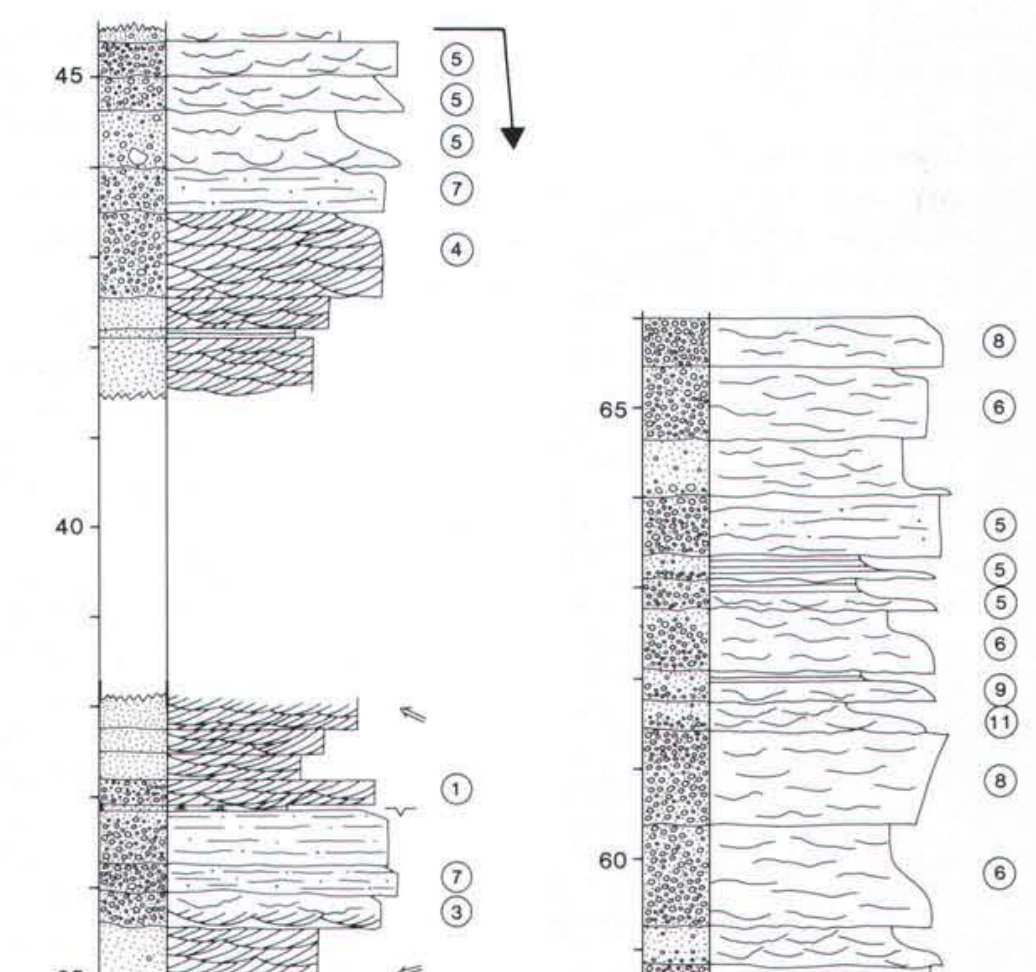

(3)

(5)

(2)
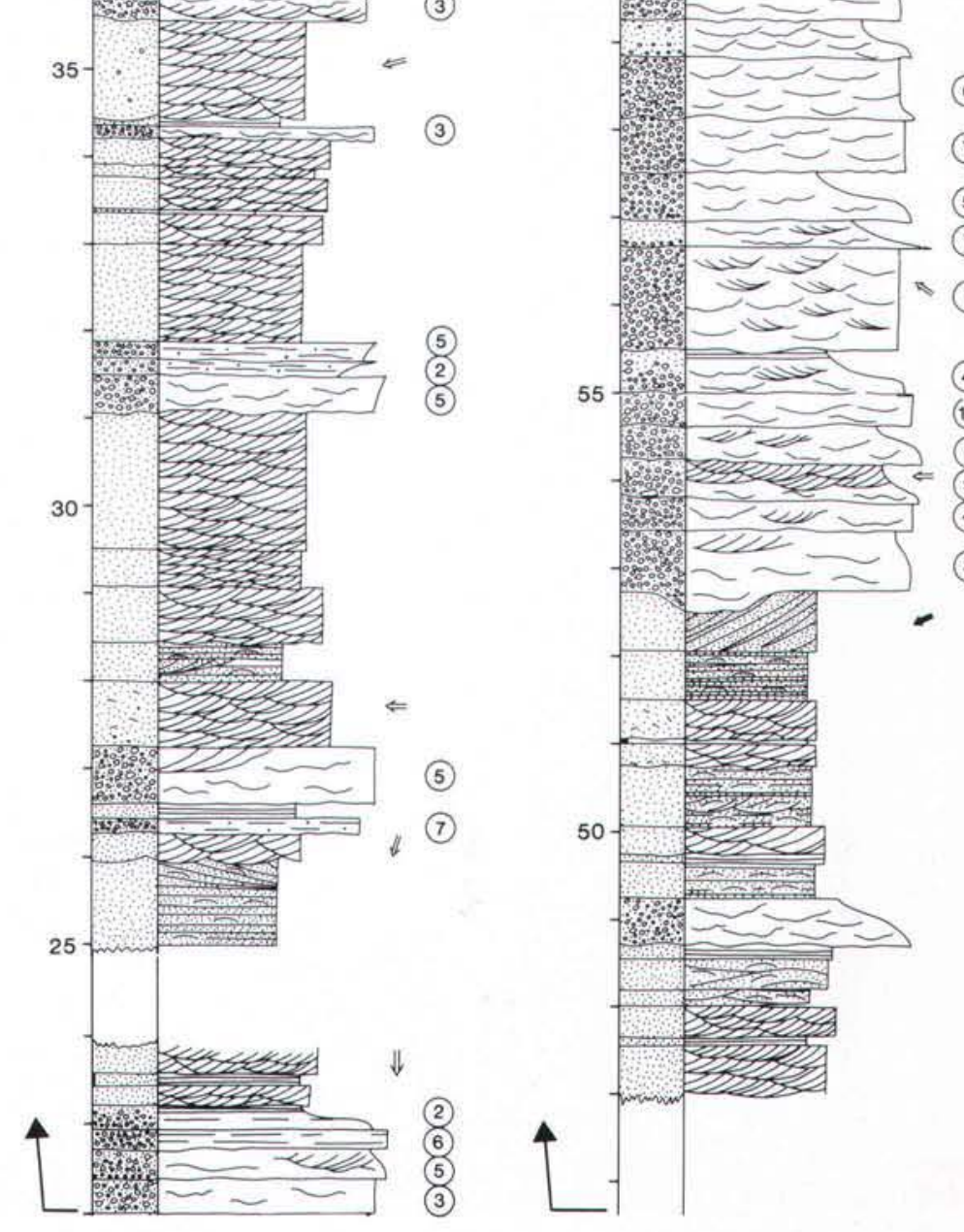
Palaeowinds are from the east-northeast (Olsen, 1993: Olsen \& Larsen, 1993).

Boundaries. At Högbom Bjerg in Moskusokselandet the lower boundary is characterized by an upward abrupt transition from red recessive sandstones of the Udkiggen Formation (western Högbom Bjerg) and Sofia Sund Formation (eastern Högbom Bjerg) to red resistant pebbly sandstones and conglomerates of the Rødsten Formation. The top of the formation is not exposed on Högbom Bjerg (sections 23, 24; Figs 61, $62)$.

At and immediately east of Victor Madsen Bjerg (Fig. 61), Gauss Halvø, the lower boundary is defined by an abrupt transition from fine-grained red aeolian sandstones below (Udkiggen Formation) to red medium-grained sandstones and conglomerates above (Rødsten Formation). Siltstones are interbedded with the sandstones in the basal part of the formation in western Victor Madsen Bjerg (Fig. 65). The formation is conformably overlain by the Agda Dal Formation of the Celsius Bjerg Group at Victor Madsen Bjerg. Little change in lithology is involved, but the transition is clearly identifiable in the field as an upward abrupt transition from recessive red sandstones to resistant darker red conglomerates (east) and sandstones (west). Also a change in palaeocurrent direction is involved, SSW in the Rødsten Formation, NNW in the Agda Dal Formation (Olsen, 1993). A basaltic lava, up to $15 \mathrm{~m}$ thick, occurs immediately above the boundary on westernmost Victor Madsen Bjerg (Larsen, 1990a, b). On Sederholm Bjerg, east of Victor Madsen Bjerg, the formation is unconformably overlain by the Agda Dal Formation (Fig. 61).

In eastern Gunnar Andersson Land the pebbly grey and red sandstones of the Rødsten Formation interfinger with red pebble free sandstones of the Udkiggen Formation (Fig. 43). The Rødsten Formation is partly conformably and partly unconformably overlain by red sandstones of the Agda Dal Formation. In central Gunnar Andersson Land, at Rødsten (Figs 61, 72), the Rødsten Formation partly overlies and partly interfingers with the Andersson Land Formation. Lithologically these two formations are almost identical. The Andersson Land Formation can, however, be distinguished by the slightly darker colour and presence of 1.5-7 $\mathrm{m}$ thick tabular units of lateral accretion bedding in the sandstones. The upper boundary of the Rødsten Formation is observed at Rødsten (Fig. 72). Here it is concordantly overlain by the Agda Dal Formation. The formations are of identical lithology, composed of fine to medium-grained sandstones associated with $5-10 \%$ siltstones. The colour is, however, slightly different. being lighter red or reddish grey in the Agda Dal Formation compared to the Rødsten Formation. Also a change in palaeocurrent directions is involved, being directed towards the southwest in the Rødsten Formation and towards the north-northeast in the Agda Dal Formation (Olsen, 1993; Olsen \& Larsen, 1993).

Distribution. The Rødsten Formation is exposed in eastern Moskusokselandet, central Gauss Halvø, eastern and central Gunnar Andersson Land (Fig. 61).

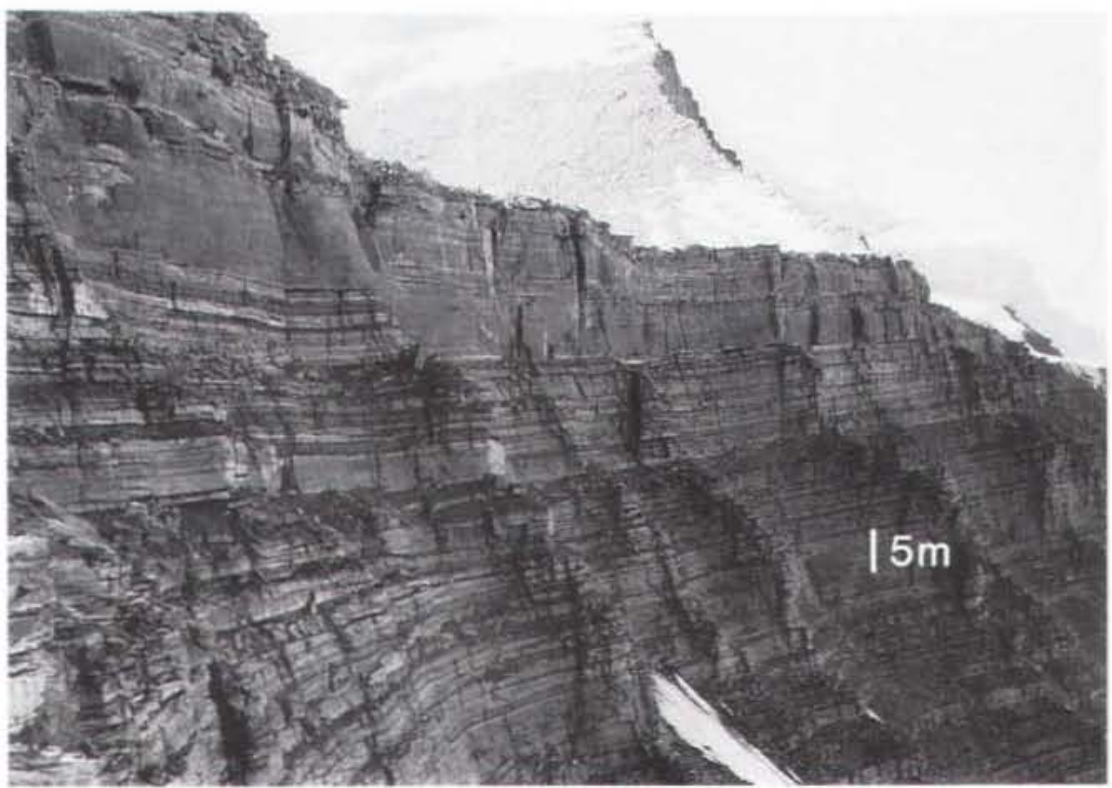

Fig. 77. Bedding characteristics of the Rødsten Formation at type section 26 (Figs 61, 63), the mountain Rødsten in Gunnar Andersson Land. The sediments are dominated by thin beds of sandstone alternating with thinner siltstone beds. The upper $c$. $10 \mathrm{~m}$ of the cliff are dominated by aeolian sandstone. The cliff faces Kejser Franz Joseph Fjord and top of cliff is $c .640 \mathrm{~m}$ above the base of the formation. 
Fig. 78. Southwestward facing cliff of the mountain Smith Woodward Bjerg, Gauss Halvo, showing section 20 (Figs 61. 62) and lower part of section 30 (Figs 85, 89). The ridge is the type section for the Woodward Bjerg Formation (WWB) and reference section (to the left of photograph) for the Udkiggen and Andersson Land Formations (U and $A L$ ). and also reference section for the Agda Dal Formation (AGD) and Elsa Dal Formation (ED) of the Celsius Bjerg Group (CB GRP). The Aina Dal Formation (AD) and Wimans Bjerg Formation (WB) of the Celsius Bjerg Group are also observed as well as part of the Sofia Sund Formation (SS) of the Kap Kolthoff Group (KK GRP). KG GRP: Kap Graah Group. Maximum cliff height is $c .1200 \mathrm{~m}$.

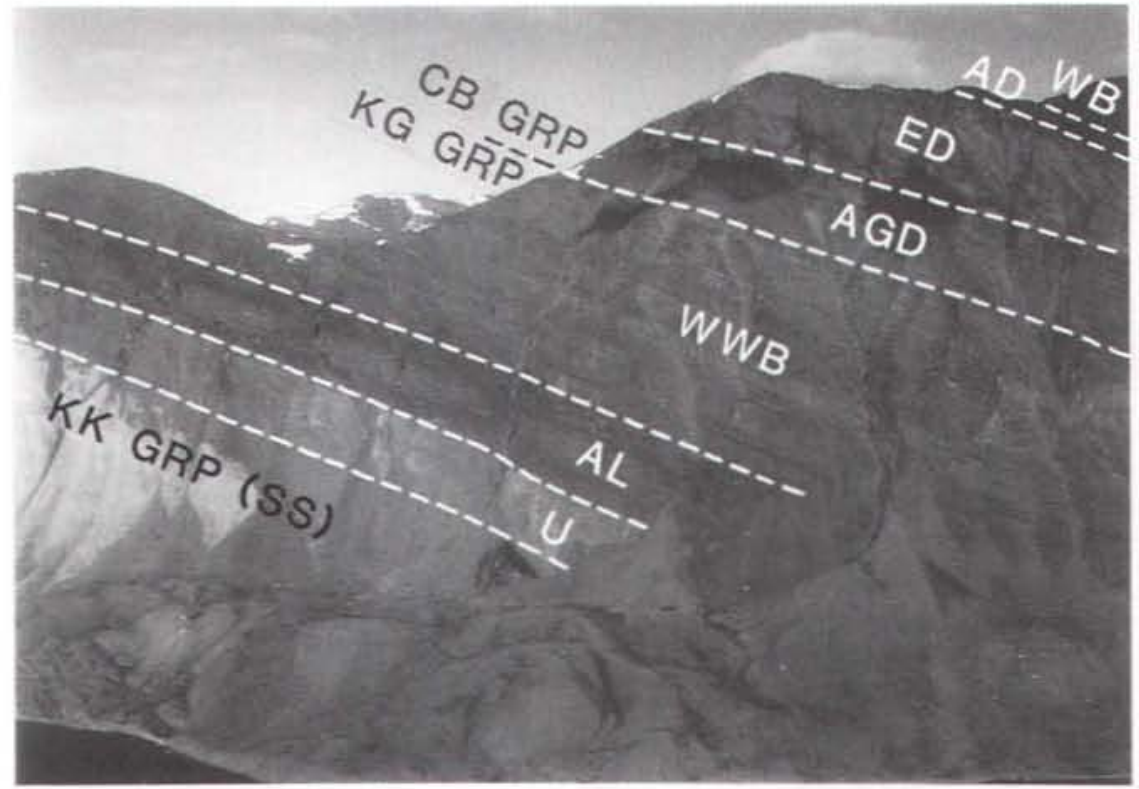

Geological age. Fossil fish of Famennian age have been identified in this formation (Friend $e t$ al., 1983).

Subdivisions. The formation is not subdivided. The conglomeratic alluvial fan deposits may be defined as members or independent formations, as well as the dominantly aeolian sandy interchannel deposits. These constituent units were, however, insufficiently defined and mapped in the field, and further investigations are needed for identification of these probable members or formations.

\section{Woodward Bjerg Formation new formation}

History. This formation was included in Kulling's (1931, fig. 4) 'upper red sandstone series', in Bütler's (1935, 1959, 1961) 'Kap Graah Series' and also in Nicholson \& Friend's (1976) Kap Graah Group. It was shown as part of the 'Cape Graah Series' on the map of Koch \& Haller (1971).

Name. After Smith Woodward Bjerg, southern Gauss Halvø (Fig. 61).

Type section. The type section is Smith Woodward Bjerg (section 20, Figs 61, 62, 78). Reference section is Rødtop (section 19, Figs 61, 62, 79). No detailed reference sections were measured.
Thickness. At Smith Woodward Bjerg on Gauss Halvø the formation is $450 \mathrm{~m}$ thick. The unit measures $c .100$ $\mathrm{m}$ of Rødtop in western Moskusokselandet (Larsen. $1990 \mathrm{c})$.

Lithology and sedimentary structures. The formation is composed of red fine to medium-grained sandstones. It is characterized by the abundance of parallel lamination, generally forming $30-50 \%$ of the formation (Fig. $80)$. Also characteristic is the presence of trough and planar cross-bedding in single sets $0.5-1 \mathrm{~m}$ thick, rarely up to $4 \mathrm{~m}$ thick, forming $40-50 \%$ of the formation.

Depositional environment and palaeocurrents. The Woodward Bjerg Formation is aeolian in origin, with only c. $10 \%$ fluvial deposits. It was deposited as small sandsheets and barchanoid dunes (Olsen, 1993). Palaeowinds blew from the east-northeast.

Boundaries. The lower boundary is placed where the solid red sandstones of the formation overly the alternating red sandstones and siltstones of the Andersson Land Formation. The two formations contrast in that the Woodward Bjerg Formation is generally resistant, whereas the Andersson Land Formation is generally recessive (Fig. 79). In Gauss Halvø the upper boundary of the formation is marked by the base of the first siltstone bed in the interbedded red sandstones and siltstones of the overlying Agda Dal Formation. At Rødtop (Fig. 79) the Woodward Bjerg Formation is 


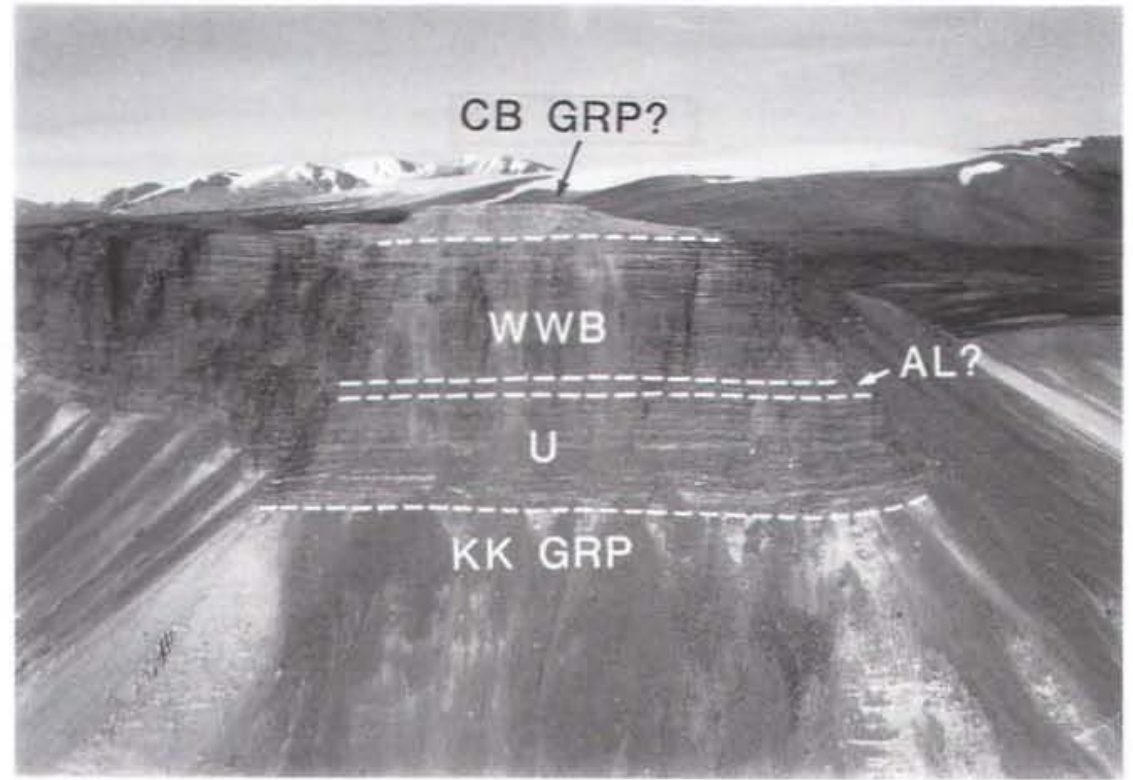

Fig. 79. The mountain Rødtop in western Hudson Land, viewed towards the east. Section 19 (Figs 61 . 62) was measured immediately to the left of this photograph. The recessive deposits of the Kap Kolthoff Group (KK GRP) are overlain by the resistant deposits of the Udkiggen Formation (U) and Woodward Bjerg Formation (WWB). An intervening thin recessive unit is interpreted as the Andersson Land Formation (AL) although at section 19 this unit is poorly exposed. The recessive white sandstones topping the outcrops may be part of the Celsius Bjerg Group (CB GRP?), but they are very poorly exposed. The thickness of the Kap Graah Group sediments $(\mathrm{U}+\mathrm{AL}+\mathrm{WWB})$ is $c$. $210 \mathrm{~m}$.

abruptly overlain by light grey, pebbly, fine to mediumgrained sandstones. These deposits are highly weathered, and a definite assignment to a formation is not possible. The most likely interpretation is assignment to the Rodsten Formation or the Agda Dal Formation. The Woodward Bjerg Formation, in general, is interpreted to interfinger with the Rødsten Formation towards the north, south and east, although these transitional zones have not been studied.
Distribution. The formation crops out on Rødtop in western Hudson Land close to Nordfjord and on Flett Plateau, Watson Plateau and Smith Woodward Bjerg in Gauss Halvø (Fig. 61). It is uncertain whether the formation is present on Sederholm Bjerg and Victor Madsen Bjerg, as shown in Fig. 61, because the rocks have only been studied from a distance.

Geological age. No fossils have been identified from this formation. It is believed to be Famennian in age like the rest of the Kap Graah Group.

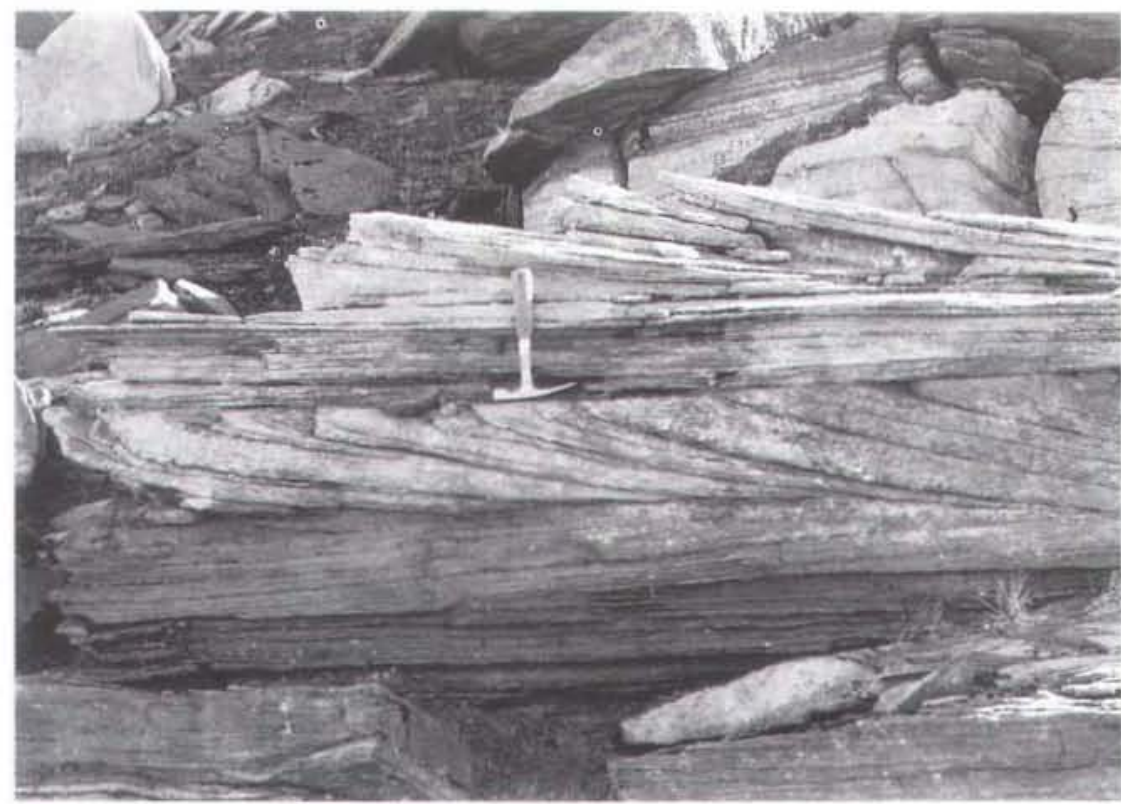

Fig. 80. Typical flat-bedding and relatively small solitary cross-sets in aeolian sandstones of the Woodward Bjerg Formation at type section 20 (Figs 61, 62), Smith Woodward Bjerg. Hammer for scale. 
Fig. 81. Vertical aerial photograph of the mountain Heintz Bjerg immediately west of Zoologdalen in Gunnar Andersson Land showing location of section 25 (Fig. 63 ) in the Kap Graah Group. The lower and upper parts of the section are indicated and correlated by a distinct (arrowed) sandstone body. The section is the type section of the Andersson Land Formation (AL) and reference section of the Zoologdalen Formation (Z). The Kap Graah Group rests on the Midnatspas Formation (M) and the Sofia Sund Formation (SS) including the Blaskbjerg Member (B) of the Kap Kolthoff Group. The Agda Dal Formation (AGD) overlies the Kap Graah Group. Copyright Kort-og Matrikelstyrelsen, Denmark, route 888M, no 1264 (A200/87).

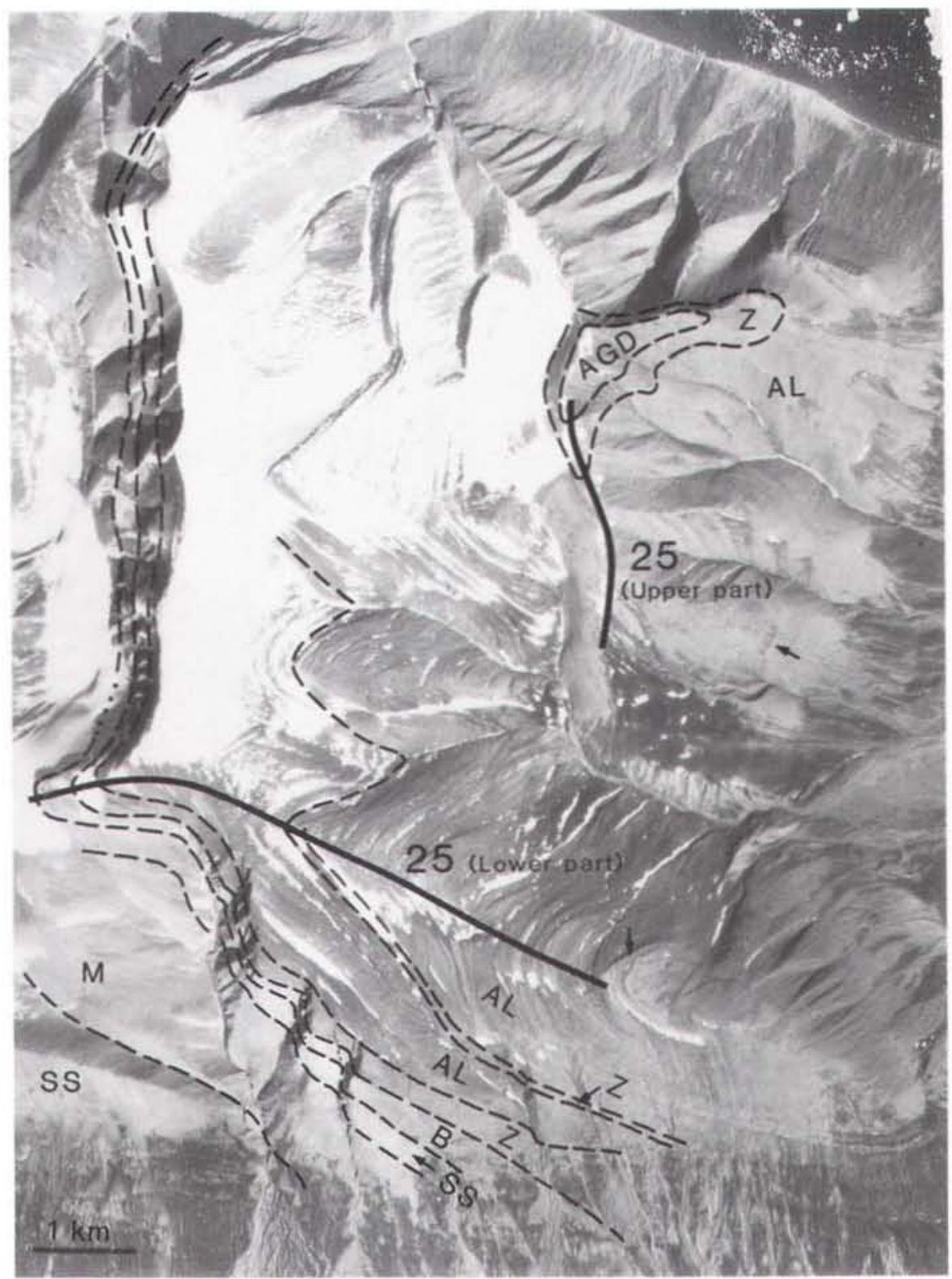

\section{Andersson Land Formation} new formation

History. This formation was included in Kulling's (1931, fig. 4) 'midmost grey sandstone series' and in Bütler's $(1935,1959,1961)$ 'Kap Graah Series' and indicated as 'Cap Graah Series' on the map of Koch \& Haller (1971). It forms part of Nicholson \& Friend's (1976) Kap Graah Group.

Name. After the peninsula, Gunnar Andersson Land, northern Ymer $\emptyset$ (Figs 6, 61).
Type and reference sections. The type section is the mountain immediately west of Zoologdalen in Gunnar Andersson Land (section 25, Figs 61, 63, 81). Reference sections are from Rødsten (section 26, Figs 61, 63, 64) and Smith Woodward Bjerg (section 20. Figs 61, 62, 65). Detailed sections are measured west of Zoologdalen (Fig. 82) and on Rødsten (Fig. 83).

Thickness. The thickness of the unit is measured as $c$. $1000 \mathrm{~m}$ on the mountain immediately west of Zoologdalen in Gunnar Andersson Land. The thickness decreases drastically eastwards to $c .150 \mathrm{~m}$ at Rødsten in 


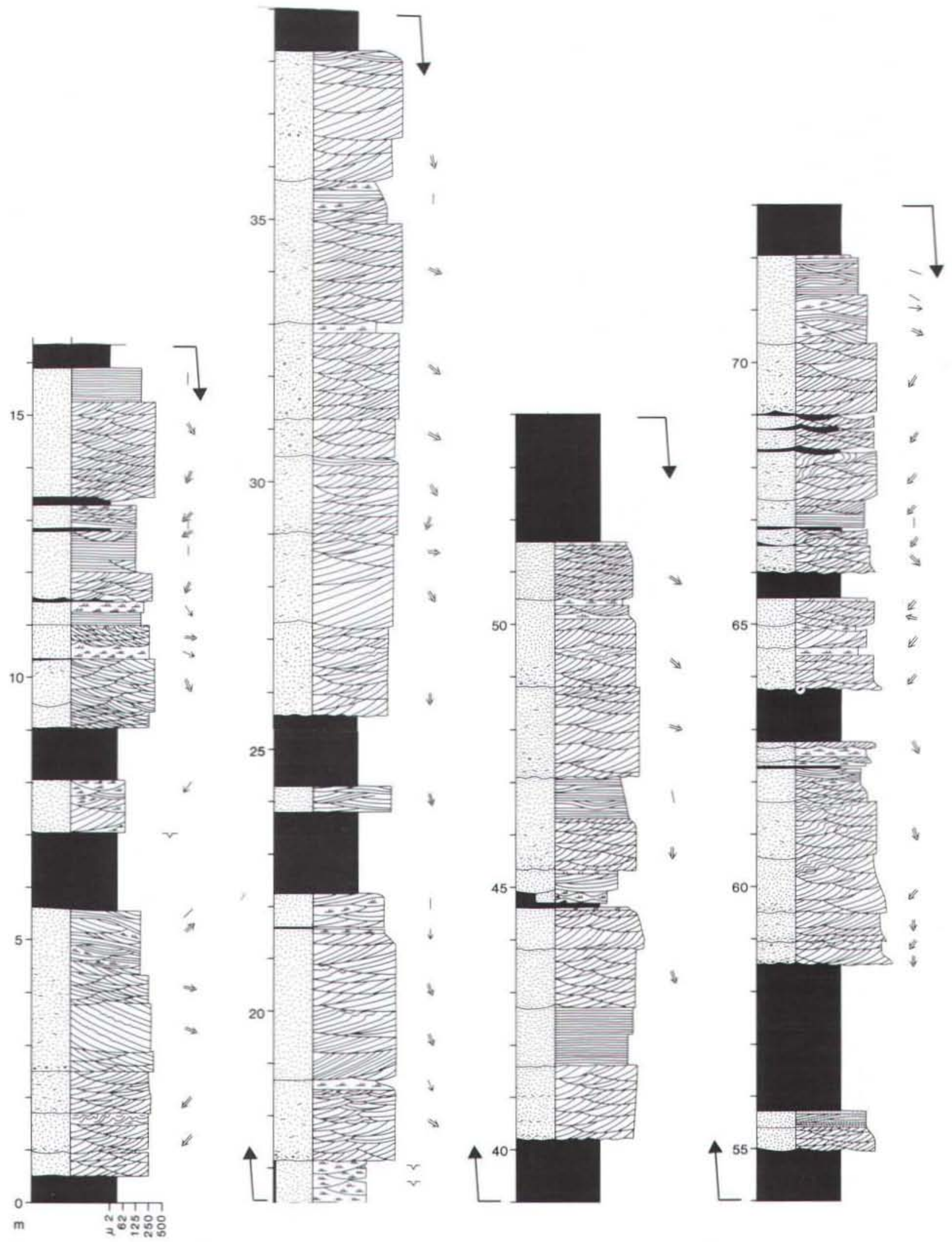

Fig. 82. See opposite page for figure text. 


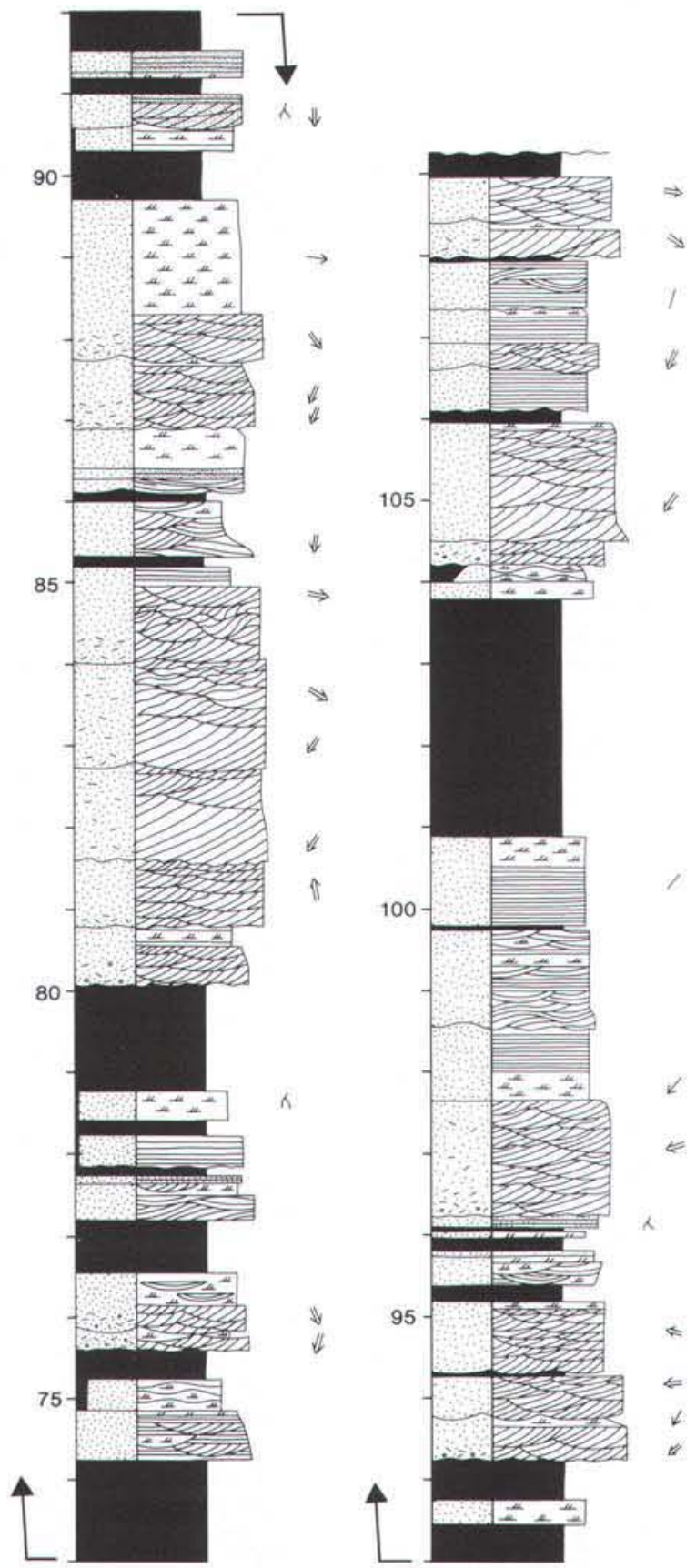

Fig. 82. Facies log from the Andersson Land Formation near type section 25 (Figs 63, 81), west of Zoologdalen in Gunnar Andersson Land. It shows the typical development of tabular sandstones with lateral accretion bedding, associated with siltstones and thin sandstone beds. The log was measured in a ravine facing Dusén Fjord (below the letter ' $\mathrm{Z}$ ' with an arrow in Fig. 81) and starts $c, 80 \mathrm{~m}$ above the base of the formation.
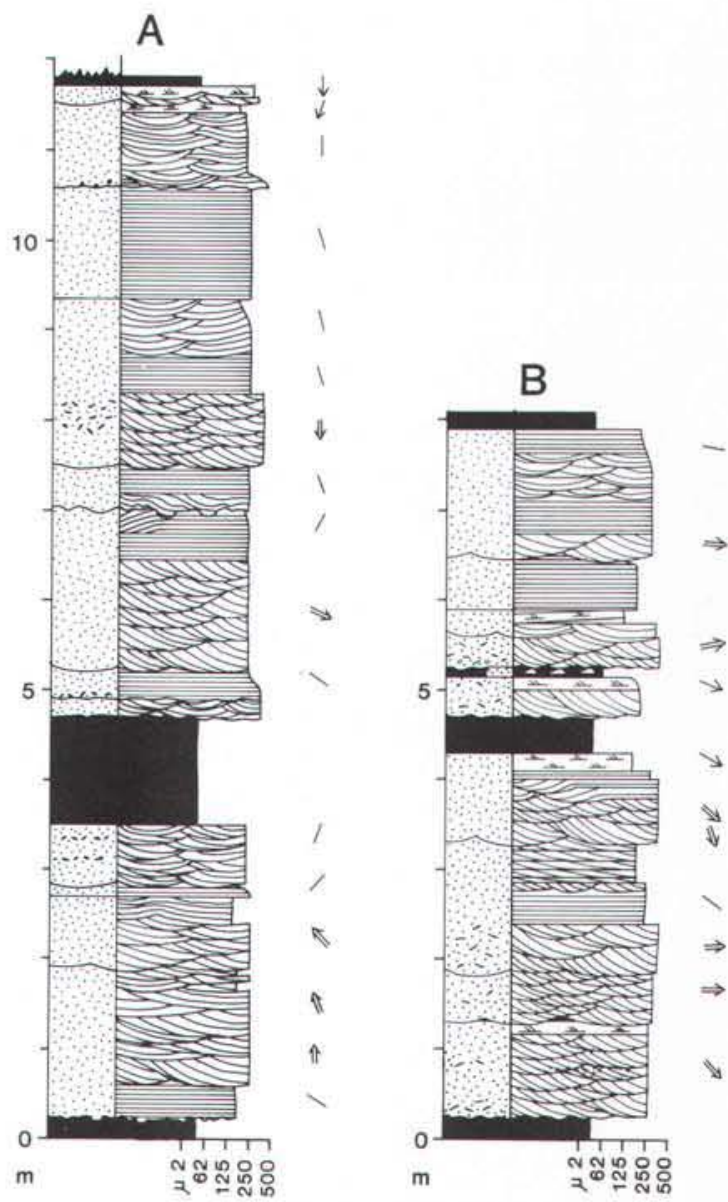

Fig. 83. Facies $\log$ from the Andersson Land Formation at reference section 26 (Figs 61, 63) at Rødsten. A is measured $c$. $20 \mathrm{~m}$ above the base and $\mathrm{B}$ is measured $c .125 \mathrm{~m}$ above the base of the formation.

Gunner Andersson Land and c. $150 \mathrm{~m}$ at Smith Woodward Bjerg in Gauss Halvø (Larsen, 1990c).

Lithology and sedimentary structures. This formation is composed of alternating fine to medium-grained tabular sandstones, $1.5-13 \mathrm{~m}$ thick, and siltstones with associated very fine-grained sandstone beds (Figs 82, 83). The tabular sandstones are mainly light red and characterized by lateral accretion bedding with component trough cross-bedding and parallel lamination. Occasionally these sandstones are grey or greenish grey. The siltstones with associated sandstone beds are mainly dark red, with rare occurrences of grey and green beds. The proportion of sandstone to siltstone varies significantly in the outcrop area.

Depositional environments and palaeocurrents. The tabular sandstones represent point bar deposition in a 
meandering river. The siltstones and very fine-grained sandstones were deposited in the adjacent flood basins. Palaeocurrents from the point bar deposits indicate that the river flowed towards the south-southeast (Olsen, 1990. 1993, in press; Olsen \& Larsen, 1993).

Boundaries. The base and top of the formation in Gauss Halvo and on Rødtop, are defined by the base of the first siltstone bed and top of the last siltstone bed, respectively (Figs 78, 79). In these areas the formation rests on the resistant sandstones of the Udkiggen Formation and is overiain by the resistant sandstones of the Woodward Bjerg Formation. The Andersson Land Formation itself is recessive at several localities in these areas.

On Rødsten (Fig. 72) the formation is likewise defined by the base of the first siltstone resting on the solid sandstones of the Udkiggen Formation. The upper part of the Andersson Land Formation at this locality is partly interdigitating with, and partly overlain by, the Rødsten Formation (Fig. 61). Lithologically these two formations are almost identical. The Andersson Land Formation can, however, be distinguished by the slightly darker colour and presence of $1.5-7 \mathrm{~m}$ thick units of lateral accretion bedding in the sandstones.

The formation interdigitates with the Zoologdalen Formation west of Zoologdalen in Gunnar Andersson Land (Figs 61, 82). It is identified by the presence of several metres thick, tabular sandstone bodies, which are absent from the Zoologdalen Formation and by the higher proportion of sandstone to siltstone, compared with the Zoologdalen Formation.

Distribution. The formation crops out on Rodtop in Moskusokselandet and in central Gunnar Andersson Land (Fig. 61). In Gauss Halvo the unit has been examined on Smith Woodward Bjerg. A unit of similar recessive appearance occurs on Flett/Watson Plateau. This may be the Andersson Land Formation, but it was not visited in the field.

Geological age. Identifiable fossils were not found in this formation. A Famennian age is assigned to it because sediments stratigraphically both above and below this formation contain Famennian fossils (Friend $e t$ al., 1983).

\section{Celsius Bjerg Group}

History. The group was originally named 'Mount Celsius Series' by Bütler (1935, 1954, 1959, 1961) (Figs 3, 4) and indicated as such on the map of Koch \& Haller (1971)(Fig. 4). Later Nicholson \& Friend (1976) renamed it 'Mount Celsius Supergroup' (Figs 4, 5). It includes parts of the upper Kap Graah Group as defined by Nicholson \& Friend (1976) (Fig. 4). It also includes outcrops previously referred to as Carboniferous (Kulling, 1931; Koch \& Haller, 1971). The rank of the unit is proposed changed to group status, because one of the two constituent groups, the 'Grönlandaspis Group' (Nicholson \& Friend, 1976) was never subdivided into formations by them. Finally the name is suggested changed to the official geographic name: Celsius Bjerg, instead of the English translation, previously used. The names: 'Remigolepis Group' and 'Grönlandaspis Group' (Nicholson \& Friend, 1976) (Fig. 5), used for parts of the Celsius Bjerg Group, are suggested abandoned as they are mixtures of biostratigraphic and lithostratigraphic nomenclature. The names were originally introduced as 'Remigolepis Series' and 'Grönlandaspis Series' by Säve-Söderbergh (1934) and Jarvik (1961) (Figs 3, 4), and correspond to the Aina Dal, Wimans Bjerg and
Britta Dal Formations, and the Stensiö Bjerg and Harder Bjerg Formations, respectively.

Name. After the mountain, Celsius Bjerg, on southeastern Ymer $\emptyset$ (Figs 6, 85, 87).

Type area. South central Gauss Halvø (Fig. 84).

Thickness. On Gauss Halvø the group reaches its maximum preserved thickness of about $1550 \mathrm{~m}$ along the south coast at Stensiö Bjerg (Fig. 89). The thickness decreases eastwards to only c. $300 \mathrm{~m}$ at Obrutschew Bjerg. On Celsius Bjerg the maximum preserved thickness is c. $1150 \mathrm{~m}$ (Larsen, 1990b, d).

Dominant lithology. The group forms a gross fining to coarsening upward succession (Fig. 89). The lower part of the group, a few tens to hundreds of metres, comprises mainly sandstones with only local siltstones and conglomerates. The lowermost sandstones are red, overlain by a unit of mainly grey sandstones. These sediments are succeeded by a few hundred metres thick unit mainly composed of siltstones. The siltstones are 
Fig. 84. Detailed geological map of the southwest coast of Gauss Halvø showing the local distribution of the formations within the Celsius Bjerg Group and the Harder Bjerg Formation. This is the type area of the Celsius Bjerg Group.

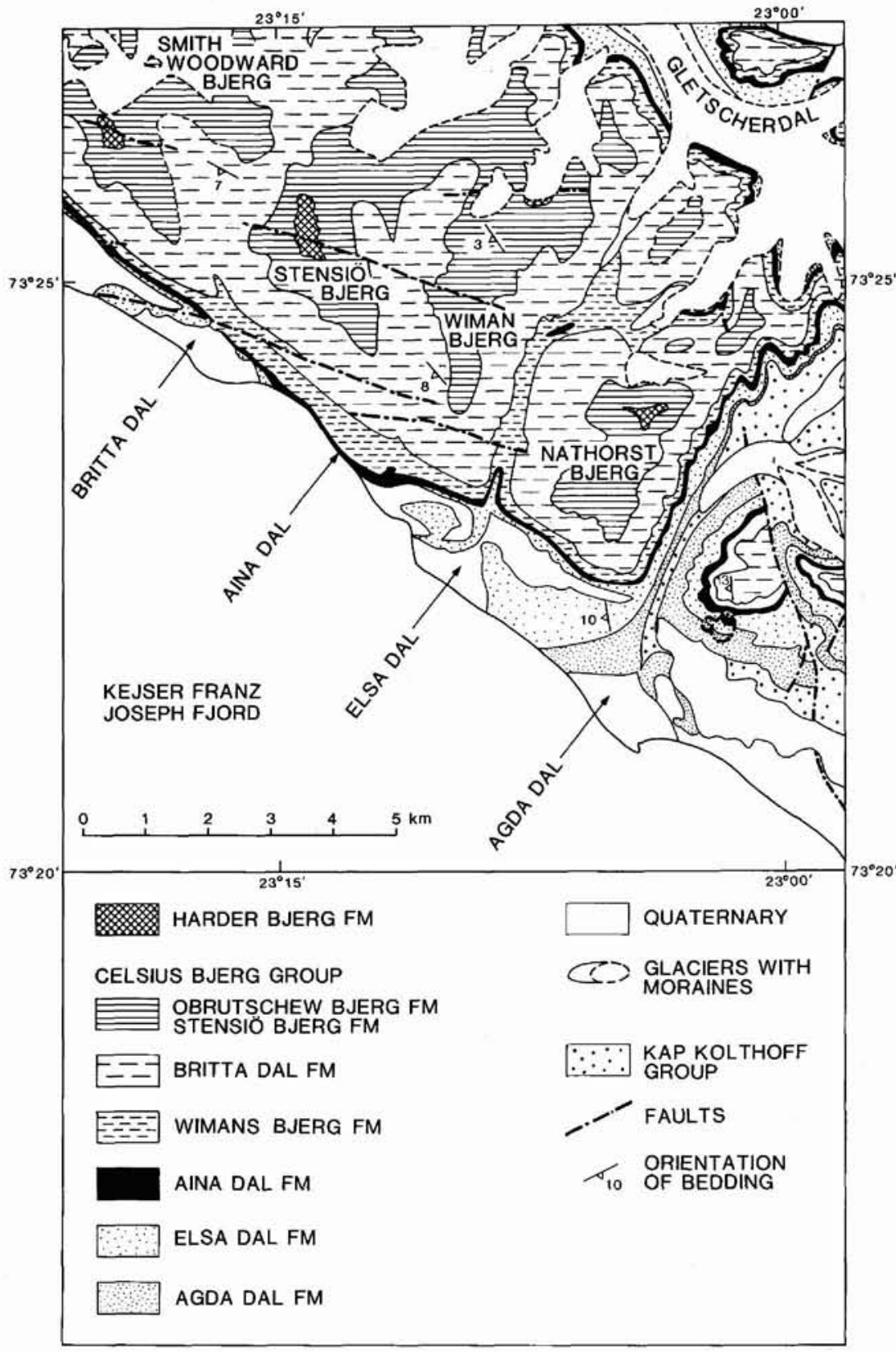

dominantly red with green and grey beds. Very fine and fine-grained sandstones are associated with the siltstones. Finally a succession of mainly yellowish grey sandstones forms the upper part of the group topped by a few metres thick black shale unit.

Depositional environments and palaeocurrents. The group is mainly of fluvial origin (Olsen, 1993). All sandstones were deposited by rivers, mainly as point bars in meandering rivers. The siltstones and shales were de- posited in flood basins and lakes. Palaeocurrents are generally northwards.

Boundaries. The group rests locally unconformably on the Kap Graah Group and Kap Kolthoff Group (Figs $43,87,92)$. The upper boundary is conformable and defined as the top of the upper black shale unit overlain by red, white and grey sandstones of the Harder Bjerg Formation. 


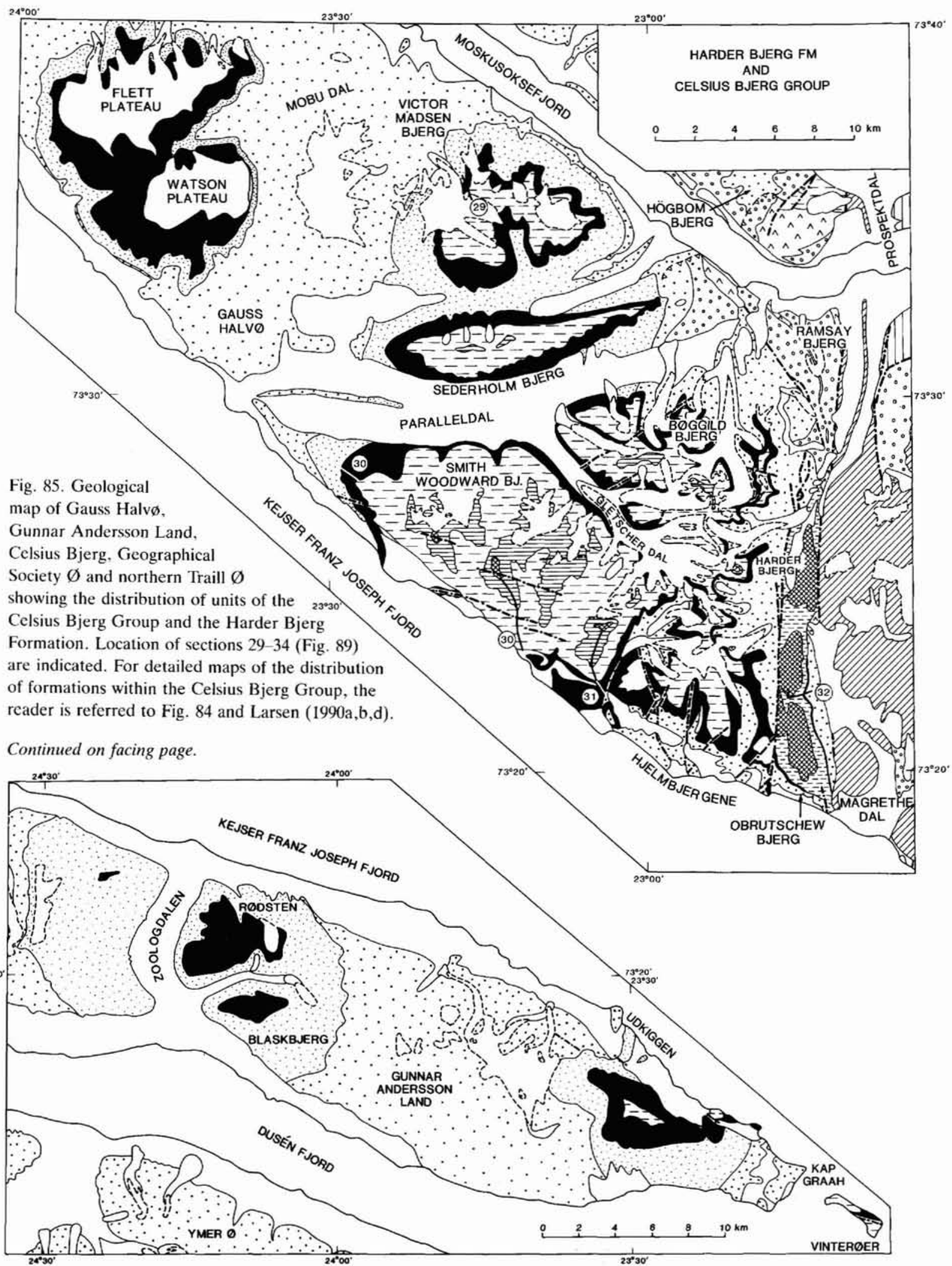




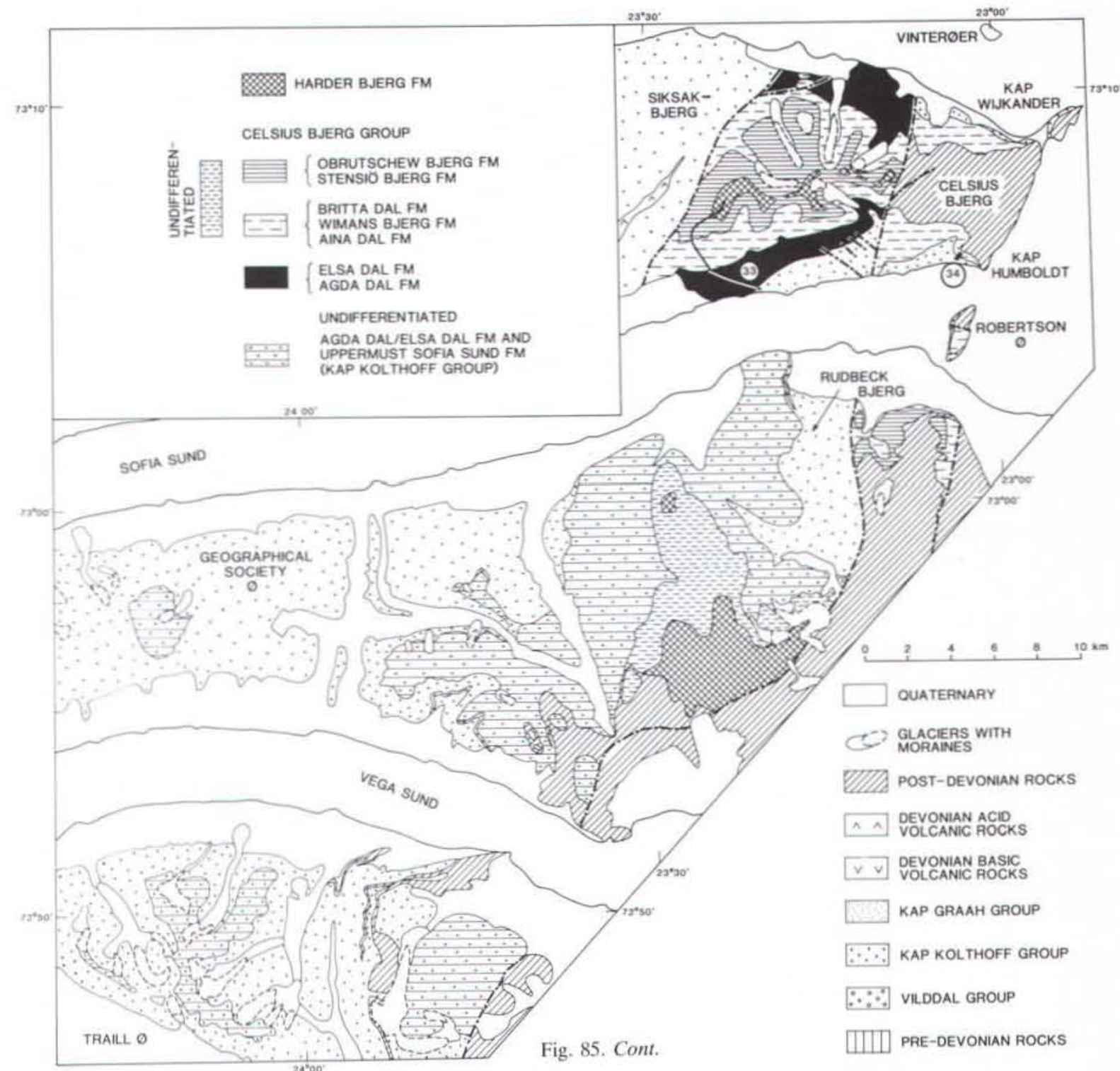

Distribution. The group crops out in southern Hudson Land, central Gauss Halvø, central and eastern Ymer $\emptyset$ and central Geographical Society $\emptyset$ (Figs 6, 85; Larsen et al., 1989; Larsen, 1990a).

Geological age. Fossil fish, especially the antiarch Remigolepis and the arthrodire Grönlandaspis, are common in the group, indicating a Famennian age of the sediments (Jarvik, 1961; Friend et al., 1983).

Subdivisions. The group is subdivided into seven formations (Plate 1), including the Agda Dal Formation, Elsa Dal Formation, Aina Dal Formation, Wimans Bjerg Formation, Britta Dal Formation, Stensiō Bjerg Forma- tion and Obrutschew Bjerg Formation. The descriptions of the formations in the next sections are chronological. starting with the oldest and ending with the youngest.

\section{Agda Dal Formation new formation}

History. Originally this formation formed part of Kulling's (1931, figs 1,3) middle grey sandstone series and Bütler's $(1935,1959,1961)$ 'Bassischichten der Mount Celsiusserie' (Figs 3,4). Parts of it were, however, included as 'Cape Graah Series' (Fig. 4) on the map of 


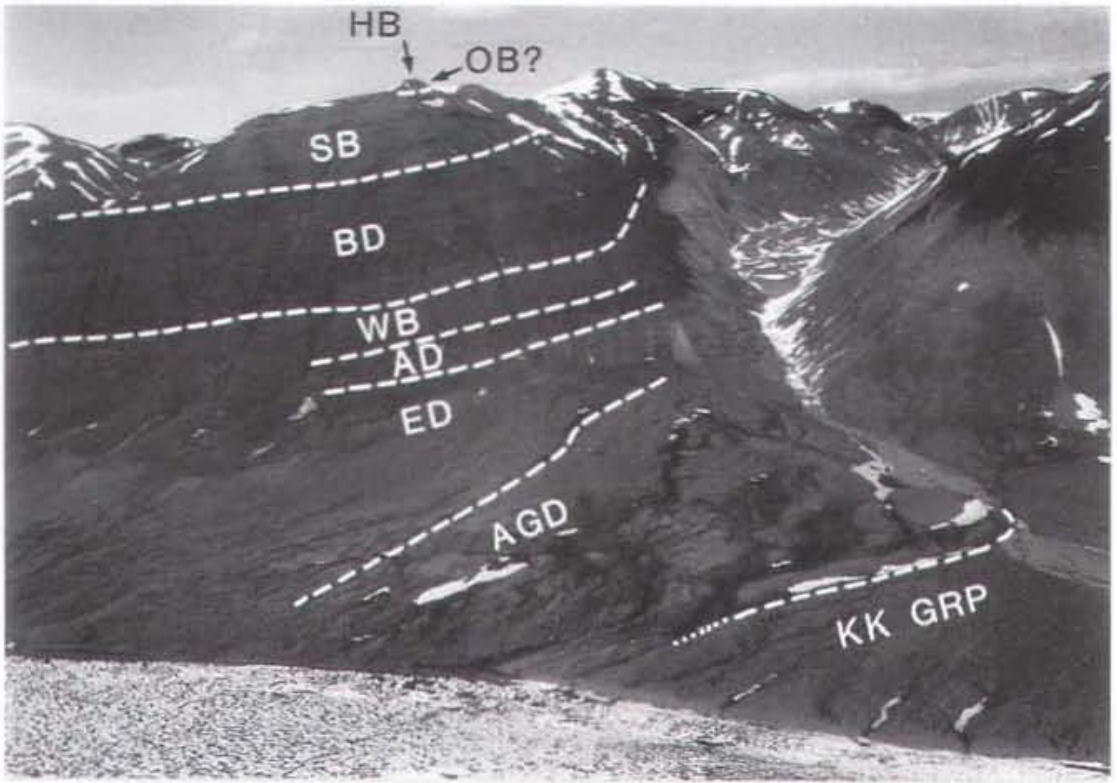

Fig. 86. The Agda Dal valley in Gauss Halvo (see also Fig. 84). Section 31 (Figs 85, 89) was measured to the left (west) of the valley (Nathorst Bjerg). This section is type section for the Agda Dal Formation (AGD) and Elsa Dal Formation (ED), and reference section for the Aina Dal Formation (AD) and Wimans Bjerg Formation (WB). Also shown are the contact to the Kap Kolthoff Group (KK GRP), exposed in the river, and the Britta Dal Formation (BD), Stensiö Bjerg Formation (SB), probable location of the Obrutschew Bjerg Formation $(\mathrm{OB})$, and Harder Bjerg Formation (HB). Height of cliff facing the fjord is $c .1200 \mathrm{~m}$.

Koch \& Haller (1971). Later, Nicholson \& Friend (1976) incorporated the formation in their Kap Graah Group (Fig. 5). The present authors propose that the formation be defined as part of the Celsius Bjerg Group, because it shares the same generally northward palaeocurrent direction as the rest of the group and, in this way, is in contrast to the Kap Graah Group, as defined by us. Moreover, the formation locally rests unconformably on the Kap Graah Group in the eastern part of the outcrop area, e.g. on Sederholm Bjerg and at Kap Graah (Larsen, 1990d).

Name. After the valley, Agda Dal, $20 \mathrm{~km}$ southeast of the mouth of Paralleldal on the southwest coast of Gauss Halvø (Fig. 84).

Type and reference sections. The type section is Agda Dal (section 31, Figs 84, 85, 86, 89). Reference sections are Victor Madsen Bjerg (section 29, Figs 65, 85, 89), Smith Woodward Bjerg (section 30, Figs 85, 89), N Obrutschew Bjerg (section 32, Figs 85, 89) and SW Celsius Bjerg (section 33, Figs 85, 89). Detailed sections were measured at Agda Dal (Fig. 88A,B), the mountain immediately west of Zoologdalen (Fig. 88C) and Obrutschew Bjerg (Figs 90, 91).

Fig. 87. South side of the mountain Celsius Bjerg, facing Sofia Sund. Section 33 (Figs 85, 89) was measured up the mountain slope, immediately below the letters 'OB'. The section is the type section of the Harder Bjerg Formation (HB). The photograph shows the Sofia Sund Formation (SS) overlain by the Agda Dal and Elsa Dal Formations ( $A G D$ and ED), succeeded by the Aina Dal (AD), Wimans Bjerg (WB), Britta Dal (BD), Stensiö Bjerg (SB), Obrutschew Bjerg (OB) and Harder Bjerg Formations. In the eastern part of the mountain (east of a major fault) the Sofia Sund Formation is directly overlain by the Aina Dal Formation of the Celsius Bjerg Group (CB GRP). Here also the Wimans Bjerg and Britta Dal Formations occur (not differentiated on this photograph) being unconformably overlain by Carboniferous deposits. The highest point visible on Celsius Bjerg is c. 1400 $\mathrm{m}$ above sea level.

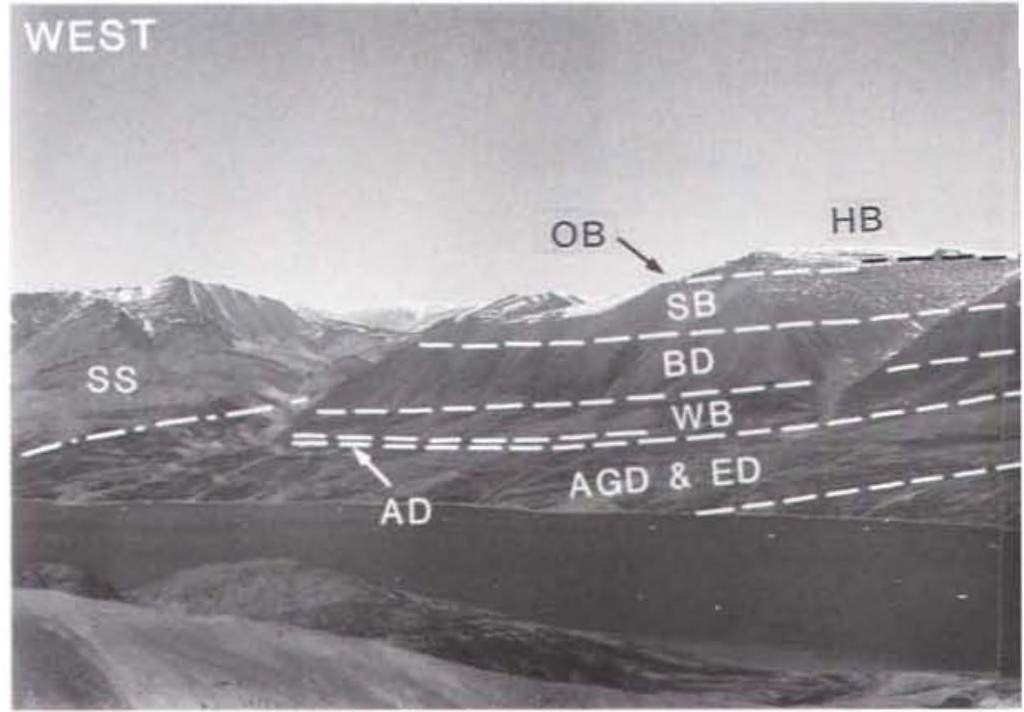



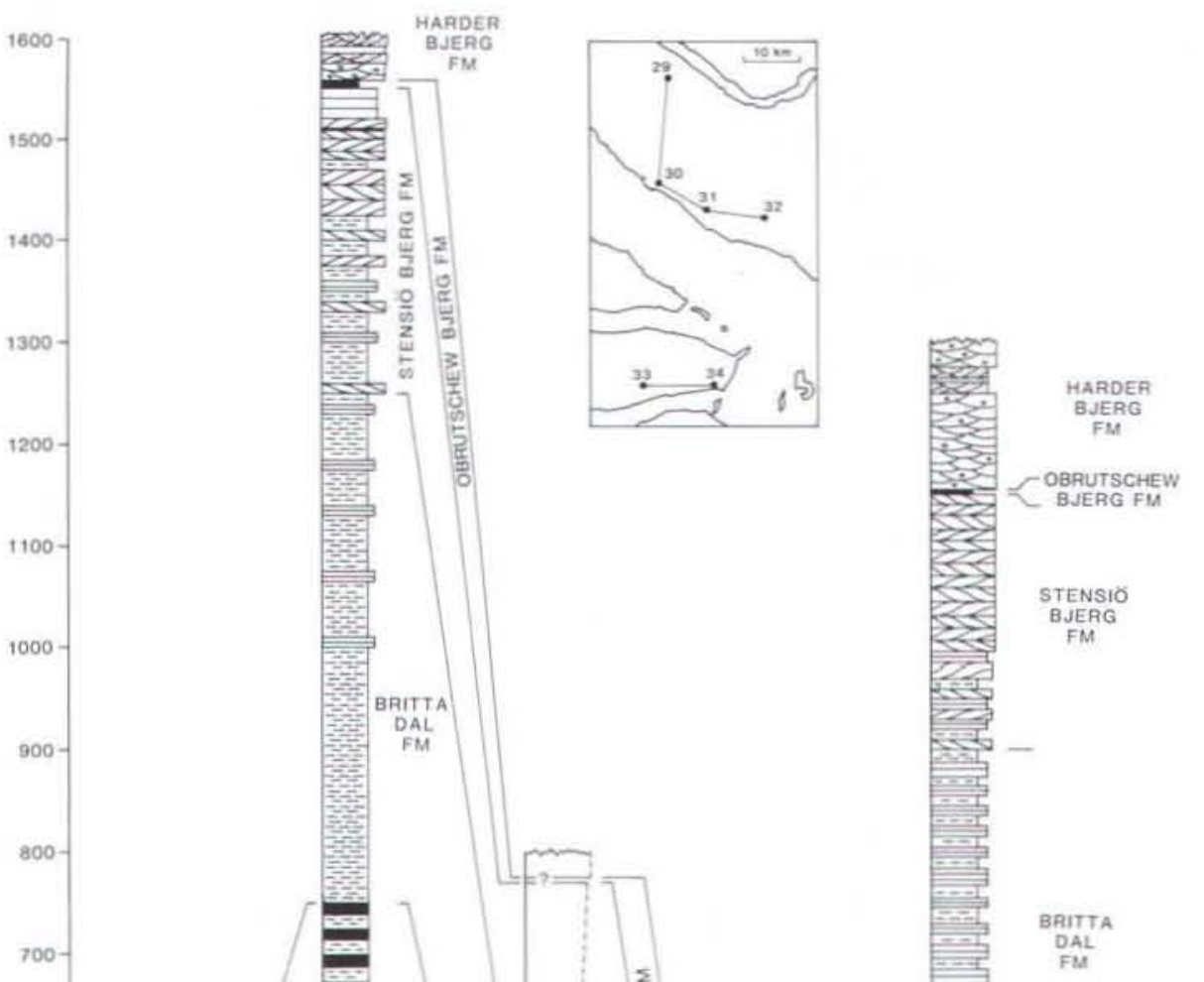

Fig. 89. Generalized sections from the Celsius Bjerg Group in Gauss Halve and Ymer $\emptyset$. For location see also Fig. 85. Legend: Plate 2. Section 30 is type section for the Aina Dal, Wimans Bjerg. Britta Dal and Stensió Bjerg Formations. Section 31 is type section for the Agda Dal and Elsa Dal Formations. Section 32 is type section for the Obrutschew Bjerg Formation. Section 33 is type section for the Harder Bjerg Formation. In section 30 the Agda Dal and Elsa Dal Formations were measured at Smith Woodward Bjerg, whereas the rest of the section was measured at Stensiô Bjerg.

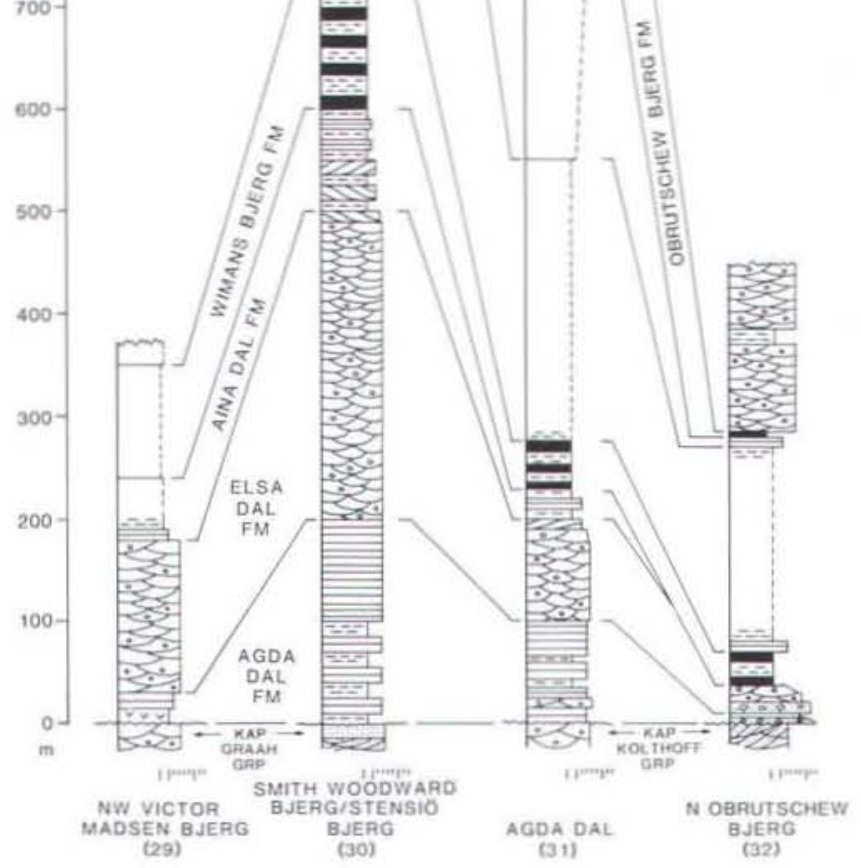


Fig, 90. Facies log from the Agda Dal and Elsa Dal Formations at the northern part of Obrutschew Bjerg. reference section 32 (Figs 85, 89). The formations are developed as two gross fining upward units. Conglomerates form important constituents of both formations. Legend: Plate 2.

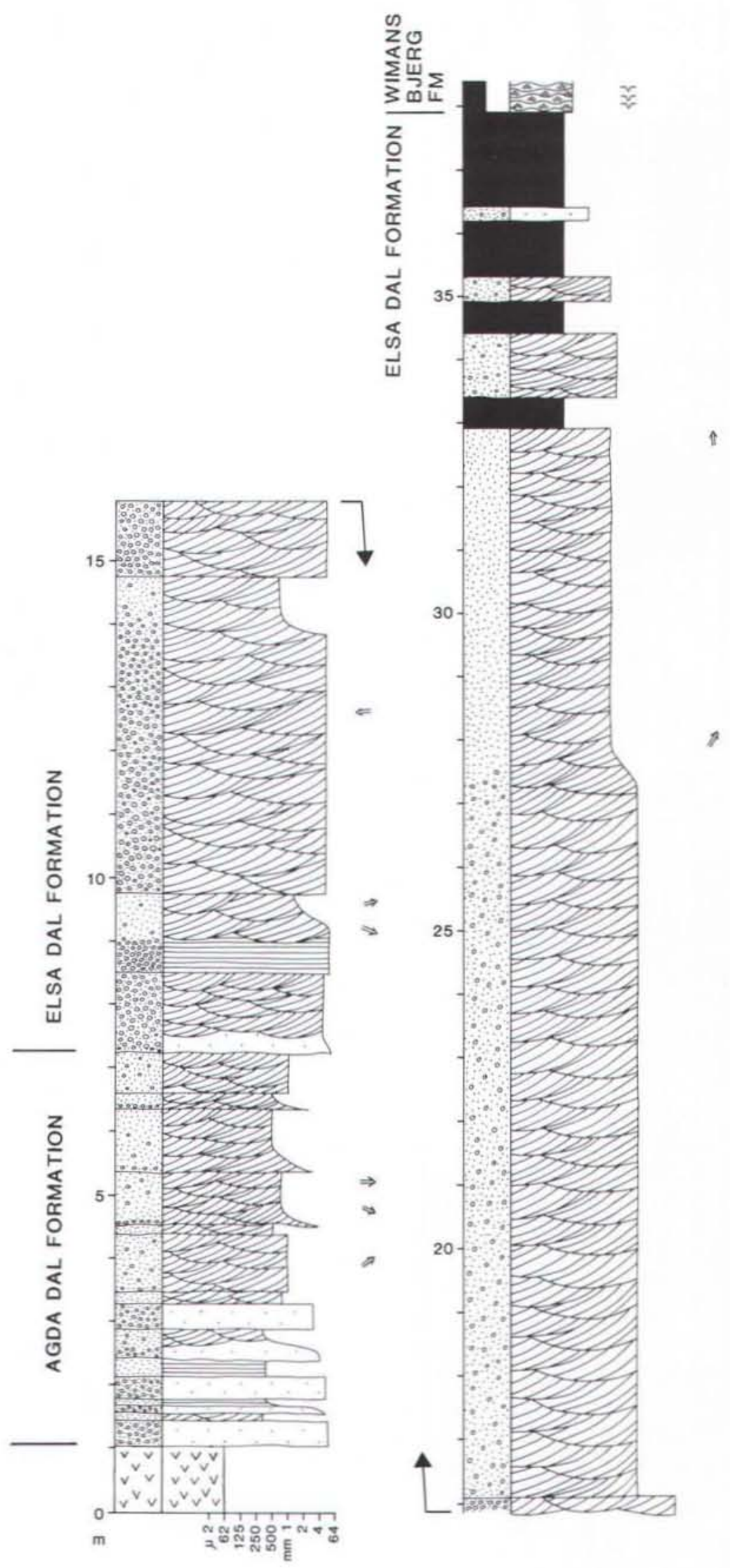




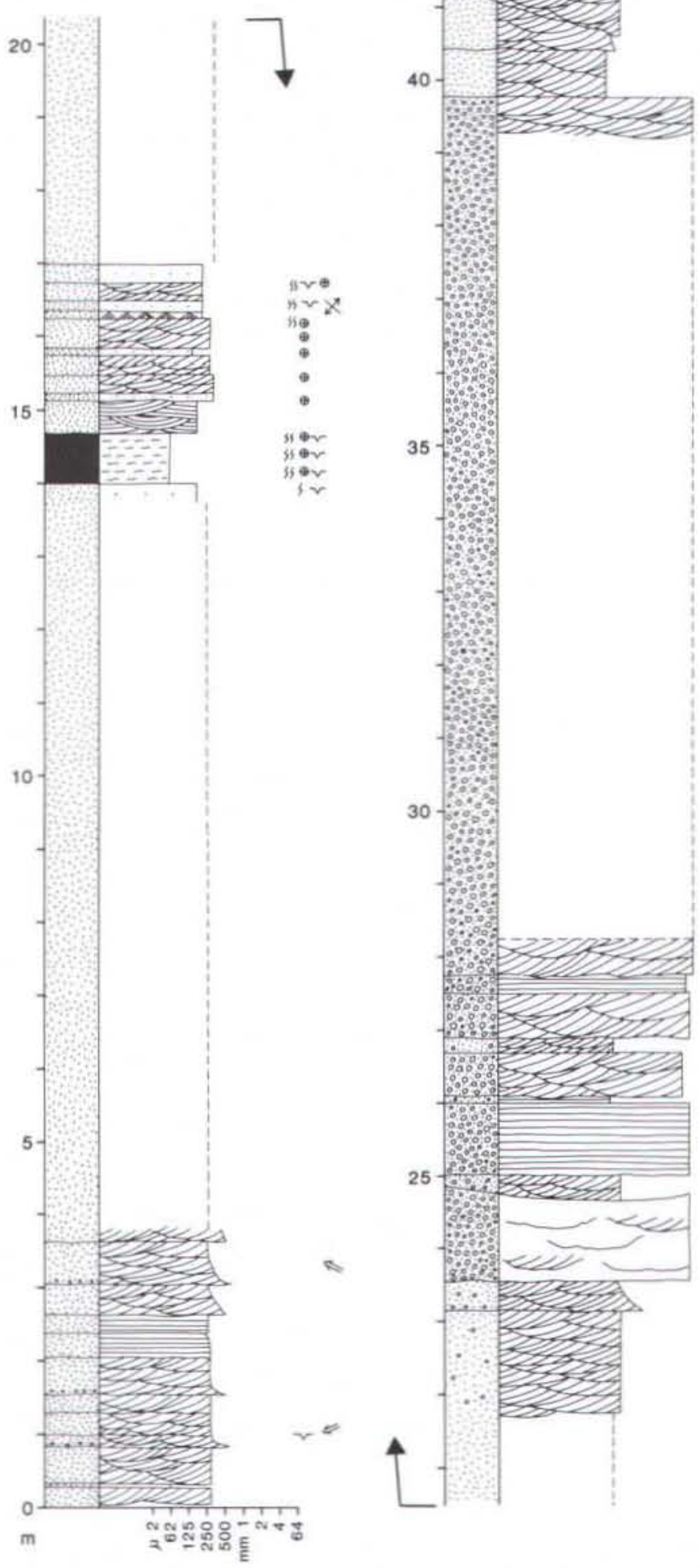

(6)

Fig. 91. Facies log from the Agda Dal and Elsa Dal Formations. The section was measured at the downfaulted coastal exposure at southern Obrutschew Bjerg. Gauss Halvo (Fig. 85). Notice the presence of conglomerates in the Elsa Dal Formation. Legend: Plate 2.

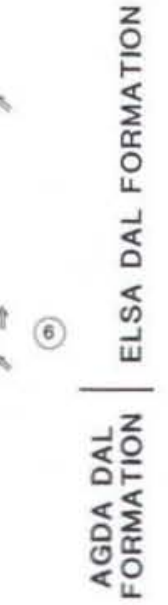


Fig. 92. Northeastern part of the mountain Bøggild Bjerg in Gauss Halvo (Fig. 85) viewed from the east. The deposits of the Langbjerg Formation (L) are tilted and unconformably overlain by the Agda Dal Formation (AGD). Elsa Dal Formation (ED), Aina Dal Formation (AD), Wimans Bjerg Formation (WB) and Britta Dal Formation of the Celsius Bjerg Group. Maximum observed thickness of the Celsius Bjerg Group sediments on this photograph is c. $200 \mathrm{~m}$.

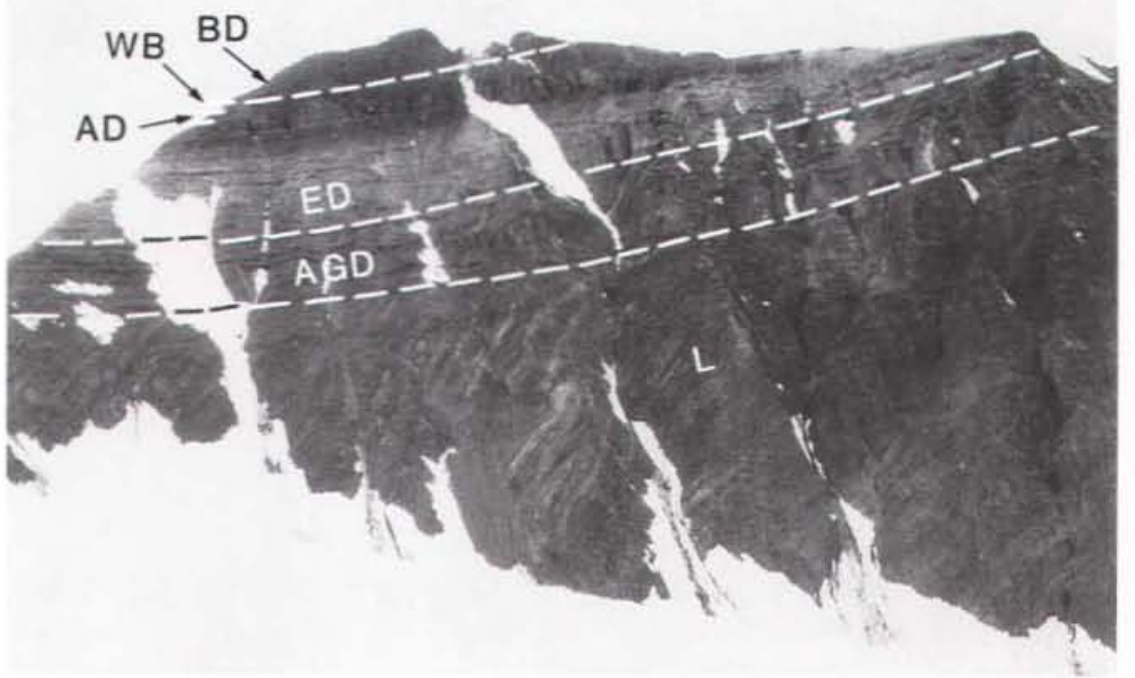

half of the Agda Dal Formation is recessive, resting on resistant rocks of the Woodward Bjerg Formation The Agda Dal Formation is, on Smith Woodward Bjerg, conformably followed by yellowish and reddish grey sandstones of the Elsa Dal Formation.

On Udkiggen, Gunnar Andersson Land (Figs 64, 93), the formation rests unconformably on grey sandstones of the Rødsten Formation. The Agda Dal Formation is conformably overlain by grey and greenish grey sandstones of the Elsa Dal Formation. The Agda Dal Formation conformabiy overlies the Rødsten Formation east of Udkiggen (Figs 43, 93) in the core of the Kap Graah syncline (Larsen, 1990a, Olsen \& Larsen, in press). The boundary is here defined by a few metres of alternating red sandstones and siltstones with huge desiccation cracks, forming the top of the Rødsten Formation. The overlying Agda Dal Formation is composed of grey sandstones.

On Rødsten and Blaskbjerg (Figs 61, 72) the Agda Dal Formation rests conformably on the Rødsten Formation. The two formations are here of identical lithology. The colour is, however, slightly different, being lighter red or reddish grey in the Agda Dal Formation. Also a change in palaeocurrent directions is involved, being directed towards the southwest in the Rødsten Formation and towards NNE in the Agda Dal Formation. The formation forms the top of the mountains. On Heintz Bjerg the Agda Dal Formation conformably

Fig. 93. Southeastern part of the mountain Udkiggen in eastern Gunnar Andersson Land, Dusén Fjord is seen in the foreground. The photograph shows the location of the angular unconformity between the deposits of the Kap Graah Group (KG GRP) and the Agda Dal Formation (AGD) of the Celsius Bjerg Group. The Elsa Dal Formation (ED) and probably the Aina Dal Formation (AD) are also visible. The latter, however, was not checked in the field. Highest point of mountain visible on the photograph is $c$. $1200 \mathrm{~m}$ above sea level.

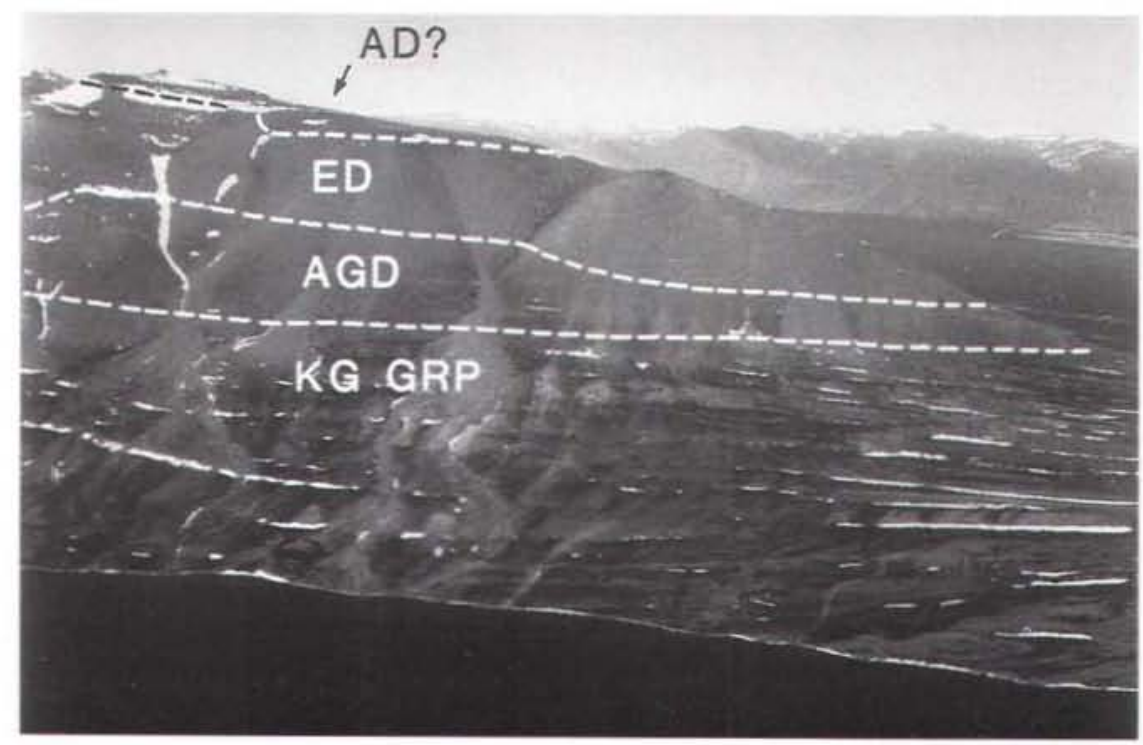


overlies the Zoologdalen Formation (Fig. 82). The transition is not associated with a lithological change. It is, however, recognized by a slight change to a lighter red colour in the Agda Dal Formation. This change is associated with a change in palaeocurrent directions from southeastwards in the Zoologdalen Formation to northwards in the Agda Dal Formation. The formation forms the top of this mountain.

On Celsius Bjerg, Ymer $\emptyset$ (Figs 85, 87, Table 1), the Agda Dal Formation rests conformably or, more likely, with a parallel unconformity on the Sofia Sund Formation. Kap Kolthoff Group. The two formations are of similar facies, composed of trough cross-bedded medium-grained, red sandstones. The Agda Dal Formation is, however, almost pebble free, in contrast to the Sofia Sund Formation, and recognized by the presence of millimetre sized green spots of chloritified basalt grains 'greenspotted sandstones' of Nicholson \& Friend (1976, fig. 22). Also a palaeocurrent change from westwards in the Sofia Sund Formation to northeastwards in the Agda Dal Formation is observed. The Agda Dal Formation is conformably overlain by yellowish grey sandstones of the Elsa Dal Formation.

Distribution. The formation crops out on Gauss Halve (Larsen, 1990b, d), central and eastern Ymer $\emptyset$, and possibly also on Geographical Society $\emptyset$. but the unit has not been examined in this area (Figs 84, 85; Larsen. 1990a).

Geological age. Nicholson \& Friend (1976) obtained Bothriolepis bones from the formation at Celsius Bjerg. This may indicate a Famennian age (Jarvik, 1961).

\section{Elsa Dal Formation}

new formation

History. This formation formed part of Kulling's (1931, figs 1.3) middle grey sandstone series (Fig. 3) and Bütler's $(1935,1959,1961)$ 'Basisschichten der Mount Celsiusserie'. Parts of it were, however, indicated as 'Cape Graah Series' (Fig. 4) on the map of Koch \& Haller (1971). Later, Nicholson \& Friend (1976) included the unit in their Kap Graah Group (Fig. 4). The present authors propose that the formation be defined as part of the Celsius Bjerg Group, because it shares the same general palaeocurrent trends towards the north as the rest of the group.

Name. After the valley, Elsa Dal, on the southwest coast of Gauss Halvø (Fig. 86).
Type and reference sections. The type section is Agda Dal (section 31. Figs 85, 89). Reference sections are NW Victor Madsen Bjerg (section 29. Figs 85, 89). Smith Woodward Bjerg (section 30, Figs 85, 89), N Obrutschew Bjerg (section 31, Figs 85, 89) and SW Celsius Bjerg (section 33, Figs 85, 89). Detailed reference sections are from Wimans Bjerg (Fig. 94B), Agda Dal (Fig. 94A) and Obrutschew Bjerg (Figs 90, 91).

Thickness. The formation measures c. $300 \mathrm{~m}$ in western Smith Woodward Bjerg on Gauss Halvo. The thickness decreases to the north and east (Larsen, 1990b, d). At Udkiggen in Gunnar Andersson Land the formation reaches $c .350 \mathrm{~m}$. while the unit measures $c .100 \mathrm{~m}$ on Celsius Bjerg, eastern Ymer $\emptyset$.

Lithology and sedimentary structures. The formation is dominated by fine- and medium-grained trough crossbedded and parallel laminated sandstones (Figs 90.91). It occurs in channel formed units, 2-5 $\mathrm{m}$ thick. The colour is typically light yellowish grey, but reddish grey, greenish grey and white rocks also occur. In the easternmost part of the outcrop area, north of Obrutschew Bjerg, conglomerates occupy approximately the lower half of the formation overlain by sandstones. The uppermost $5-10 \mathrm{~m}$ of the formation are composed of alternating beds of yellowish grey and green sandstone and green, black and red siltstone. The proportion of siltstone in this interval increases from c. $10 \%$ to $c$. $50 \%$. Elsewhere in the formation siltstone only occurs as decimetre thick lenses or centimetre thick partings.
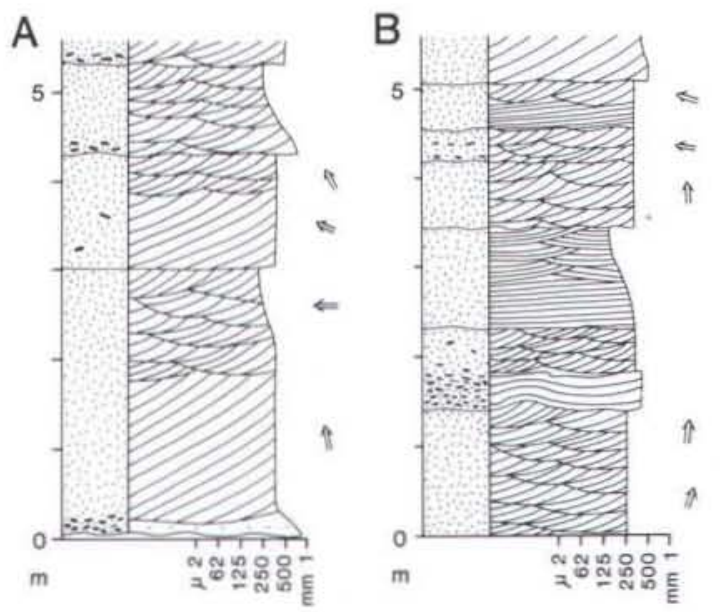

Fig. 94. Facies logs from the Elsa Dal Formation. A was measured in type section 31 (Figs 85, 89) at Agda Dal, c. $30 \mathrm{~m}$ above the base of the formation. B was measured at Wiman Bjerg, between sections 30 and 31 (Fig. 85), c. $50 \mathrm{~m}$ below the top of the formation (see also Fig. 84). Legend: Plate 2. 
Depositional environments and palaeocurrents. The Elsa Dal Formation was deposited mainly in sandy braided rivers flowing northwards (Olsen, 1993). Gravelly streams were locally important in the eastern part of the area.

Boundaries. The formation conformably overlies the Agda Dal Formation everywhere in its outcrop area. It is recognized by a transition from red rocks of the Agda Dal Formation to mainly yellowish and reddish grey rocks of the Elsa Dal Formation. The formation is conformably overlain by the dark red Aina Dal Formation at most localities. The boundary is defined as the base of the first dark red sandstone of the Aina Dal Formation. Immediately north of Obrutschew Bjerg the Elsa Dal Formation is conformably overlain by the Wimans Bjerg Formation (Fig. 91). The boundary is here placed at the base of the first wave ripple-laminated very finegrained sandstone bed of the Wimans Bjerg Formation.

Distribution. The Elsa Dal Formation crops out on Gauss Halvø and eastern Ymer $\emptyset$ (Figs 84, 85; Larsen, $1990 \mathrm{~b}, \mathrm{~d})$. It may be present on central Geographical Society $\emptyset$ (Larsen, 1990a). The unit has, however, not been examined in the field in this area.

Geological age. No fossils have been obtained from this formation. The presence of Famennian fossil fish in the formations immediately below and above this formation (Nicholson \& Friend, 1976) indicates, however, a Famennian age for the Elsa Dal Formation.

\section{Aina Dal Formation}

History. Nicholson \& Friend (1976) established the Aina Dal Formation (Fig. 5) and included it in their 'Remigolepis Group' ('Mount Celsius Supergroup'), corresponding to Säve-Söderbergh's (1934) 'Remigolepis Series, division a' of (Fig. 3). The formation was included in Kulling's (1931, fig. 1) upper red sandstone series (Fig. 3). Bütler (1935, 1954, 1959, 1961) included this formation in his 'Mount Celsius Series' (Figs 3,4) and it was indicated as part of that unit (Fig. 4) on the map of Koch \& Haller (1971).

Name. After the valley, Aina Dal, on the southwest coast of Gauss Halvø (Fig. 86).

Type and reference sections. The type section is Stensiö Bjerg at Aina Dal on the southwest coast of Gauss
A

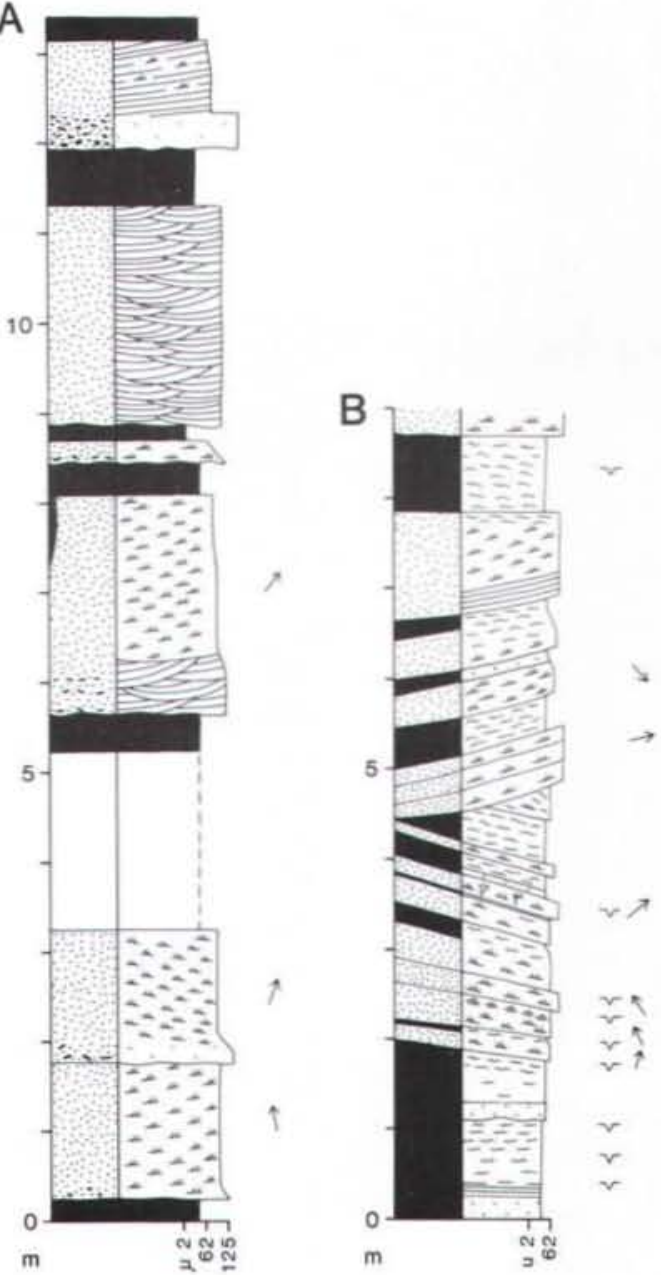

Fig. 95. Facies logs from the Aina Dal Formation at type section 30 (Figs 85, 89) at Stensiö Bjerg, Gauss Halvø. A was measured c. $40 \mathrm{~m}$ and B c. $70 \mathrm{~m}$ above the base of the formation. Legend: Plate 2.

Halvø (section 30, Figs 85, 89). Reference sections are located in Agda Dal (section 31, Figs 85, 89) and on SE Celsius Bjerg (section 34, Figs 85, 89). Detailed reference sections were measured in Aina Dal (Fig. 95) and on Stensiö Bjerg (Fig. 96).

Thickness. The thickness of the unit does not exceed $100 \mathrm{~m}$ in the Gauss Halvø. The greatest thickness occurs at Sederholm Bjerg, Smith Woodward Bjerg and Stensiö Bjerg (up to $90 \mathrm{~m}$ ), whereas the thickness decreases eastwards. On Celsius Bjerg the thickness is less than 50 m (Larsen, 1990b, d).

Lithology and sedimentary structures. The formation is composed of very fine and fine-grained sandstones and siltstones (Figs 95, 96). The rocks are generally dark red 


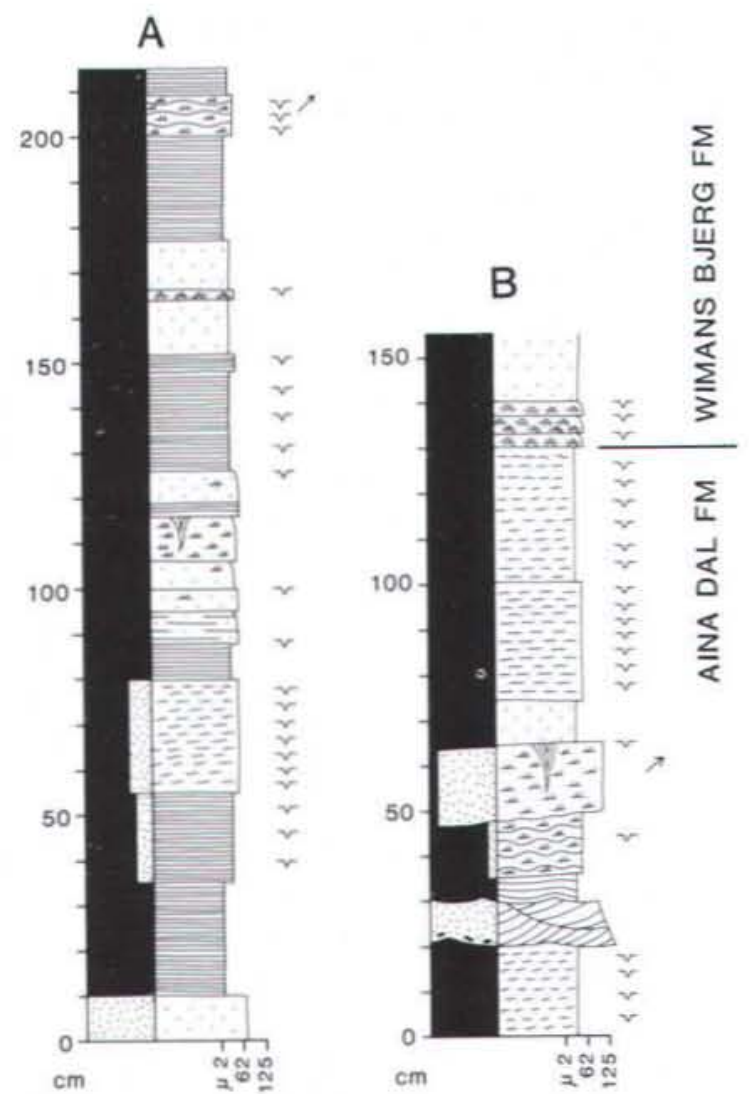

Fig. 96. Facies logs from the Aina Dal Formation at type section 30 (Figs 85, 89) at Stensiō Bjerg. B was measured at the upper boundary of the formation and $\mathrm{A}$ immediately below $\log$ $\mathrm{B}$ a few hundred metres west of B. Legend: Plate 2. but the upper 4-5 $\mathrm{m}$ are mainly grey or black with minor brown beds. The proportion of sandstone decreases upwards in the formation. The sandstones are dominated by cross-lamination, with common parallel lamination and rare trough cross-bedding. The siltstones are mainly massive or brecciated, but parallel lamination also occurs frequently. Desiccation cracks are very abundant.

Depositional environments and palaeocurrents. The formation was deposited in a meandering river and flood basin environment (Olsen, 1993). Deposition of sand on point bars occurred initially in a perennial river environment. Towards the end of Aina Dal Formation time the rivers became ephemeral, though still meandering, and the point bars became more silty. Palaeocurrents were towards the north (Nicholson \& Friend, 1976; Olsen, 1993).

Boundaries. The Aina Dal Formation lies with conformable contact above the Elsa Dal Formation (Figs 87, 97, 101). The boundary is defined by the base of the first dark red sandstone bed of the Aina Dal Formation overlying green, black or red siltstone or green or yellowish grey sandstone of the Elsa Dal Formation. On eastern Celsius Bjerg (Fig. 85) the formation overlies the yellowish grey pebbly sandstones of the Sofia Sund Formation, probably with a parallel unconformity. The boundary is here defined by the base of the first dark red sandstone or siltstone bed of the Aina Dal Formation. In Prospektdal (Fig. 85) north of Moskusoksefjord

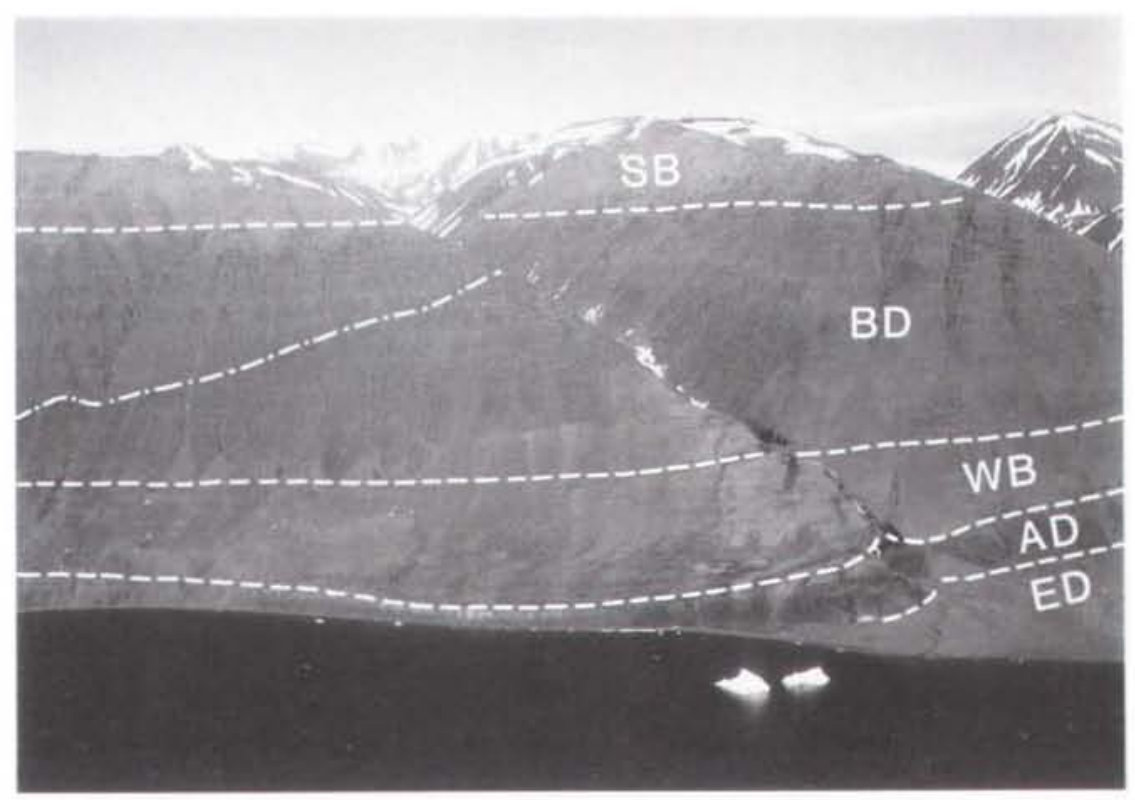

Fig. 97. The mountains Stensiö Bjerg (to the left) and Wiman Bjerg, separated by the Aina Dal valley (see Fig. 84). The upper part of section 30 (Figs 85, 89) was measured along the mountain ridge of Stensiō Bjerg. shown on this photograph. This is the type section of the Aina Dal Formation (AD), Wimans Bjerg Formation (WB) and Stensiō Bjerg Formation (SB). Also shown on this photograph is the Elsa Dal Formation (ED), exposed at the foot of Wiman Bjerg. Cliff face of Wiman Bjerg in the foreground is c. $900 \mathrm{~m}$ high. 
the unit rests on acid magmatic rocks (Larsen et al., 1989).

The Aina Dal Formation is conformably overlain by the grey and red siltstones of the Wimans Bjerg Formation (Fig. 98). The boundary is placed at the base of the first wave ripple-laminated coarse siltstone bed of the Wimans Bjerg Formation.

Distribution. This formation occurs in Gauss Halvø, eastern Ymer $\emptyset$ and probably central Geographical Society $\emptyset$ (Figs 84, 85; Larsen, 1990b, d). A small outlier has been found in Prospektdal north of Moskusoksefjord (Larsen et al., 1989).

Geological age. Numerous fossil fish, including Ichthyostega, the earliest known tetrapod, indicate a Famennian age of this formation (Friend et al., 1983).

\section{Wimans Bjerg Formation}

History. Nicholson \& Friend (1976) established this formation, forming part of their 'Remigolepis Group' ('Mount Celsius Supergroup') of mainly grey siltstone (Fig. 5). The formation was included in Kulling's (1931, fig. 1) upper red sandstone series (Fig. 3). It corresponds to the 'Remigolepis Series, division b' of SäveSöderbergh (1934) and was included in Bütler's (1935, $1954,1959,1961)$ 'Mount Celsius Series' and indicated as such (Figs 3,4) on the map of Koch \& Haller (1971).
Name. After the mountain, Wiman Bjerg, on the southwest coast of Gauss Halvø (Fig. 84). The genitive case Wimans Bjerg is maintained from Nicholson \& Friend (1976).

Type and reference sections. Stensiö Bjerg, immediately west of Wiman Bjerg on the southwest coast of Gauss Halv 6 is the type section of this formation (section 30. Figs 85, 89). Reference sections are from Agda Dal (section 31, Figs 85, 89), N Obrutschew Bjerg (section 32. Figs 85, 89) and SE Celsius Bjerg (section 34, Figs 85,89 ). The detailed section (Fig. 99) is from Stensiö Bjerg. See also sections by Nicholson \& Friend (1976. figs 10,13$)$.

Thickness. The unit is approximately $150 \mathrm{~m}$ thick in southern Gauss Halvø, decreasing to the north and east (Larsen, 1990b, d). On Celsius Bjerg the formation reaches $c .100 \mathrm{~m}$ in thickness.

Lithology and sedimentary structures. The Wimans Bjerg Formation is composed of grey and red muddy siltstones alternating with grey coarse siltstone beds (and occasionally very fine sandstones), a few to $12 \mathrm{~cm}$ thick (Fig. 99). In the upper part of this formation green siltstone beds occur. Green siltstones also occur in the easternmost outcrops, where the formation is very thin. The muddy siltstones are massive or brecciated. The coarse siltstones and sandstones are mainly wave ripplelaminated and also commonly parallel-laminated. Desiccation cracks are common in both sediment types. Occasionally channel-formed sandstones, less than $1 \mathrm{~m}$
Fig. 98. The Aina Dal waterfall occurring near the coast between Stensiō Bjerg and Wiman Bjerg (Fig. 84), Gauss Halvø. The outcrop shows the field appearance of the Aina Dal Formation (AD) and Wimans Bjerg Formation (WB). The vertical cliff height is c. $35 \mathrm{~m}$. Notice that the upper $c$. $5 \mathrm{~m}$ of the Aina Dal Formation are very resistant, whereas the underlying part of the formation is recessive.

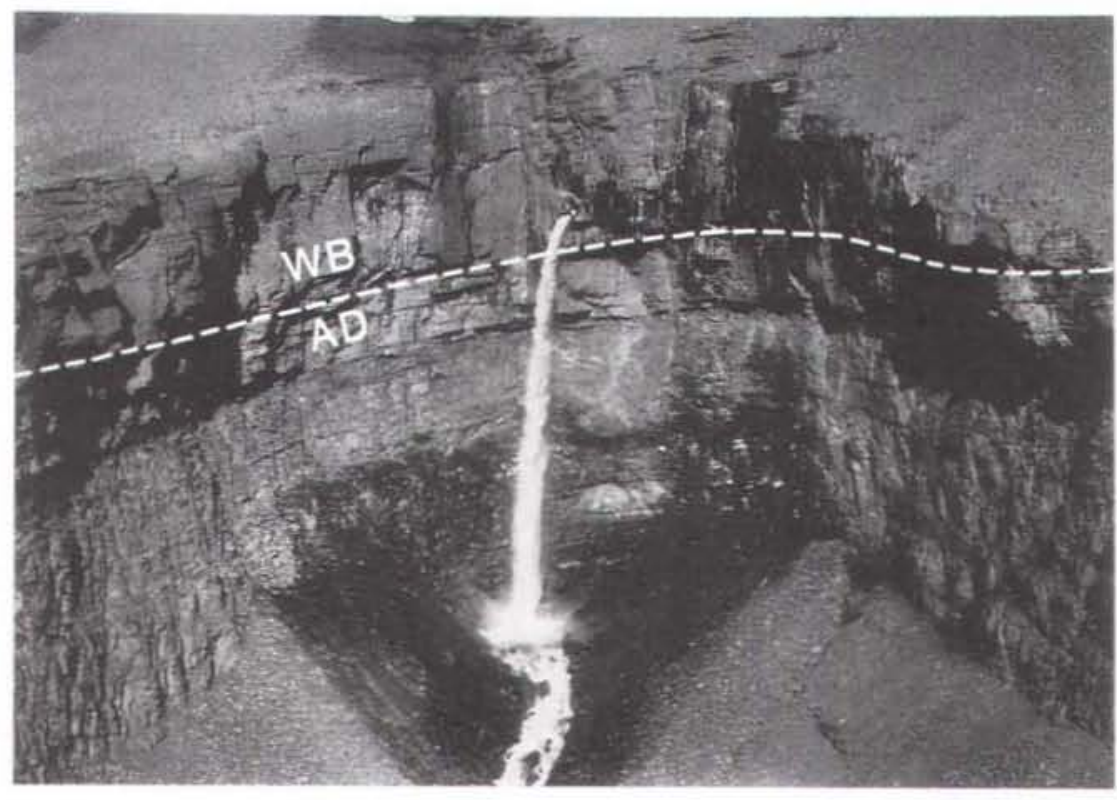




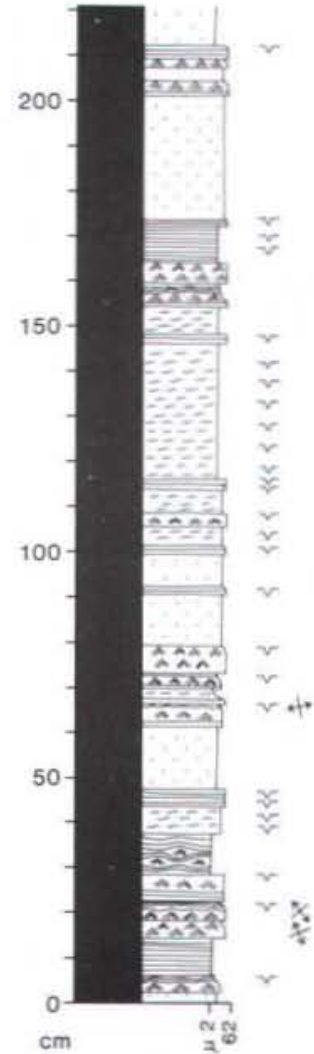

Fig. 99. Detailed facies log from the Wimans Bjerg Formation at type section 30 (Figs 85.89) at Stensiō Bjerg. The log was measured c. $20 \mathrm{~m}$ above the base of the formation. Legend: Plate 2.

thick occur. The coarse siltstones are densely carbonate cemented and in the easternmost outcrop the siltstones are interbedded with carbonates, crudely laminar and concretionary in character and exhibiting tepee-like structures.

Depositional environments and palaeocurrents. The formation was deposited in a lacustrine/playa mudflat environment (Nicholson \& Friend. 1976; Olsen. 1993, in press). The coarse siltstones and very fine sandstones were deposited during lacustrine conditions. The muddy siltstones were deposited during subaerial mudflat conditions. The limestones were deposited at the lake margin.

Boundaries. The formation rests conformably on the Aina Dal Formation (Figs 87. 97. 98, 101). The lower boundary is placed at the base of the first wave-ripple laminated coarse siltstone bed of the Wimans Bjerg Formation. On Obrutschew Bjerg the formation rests conformably or with a parallel unconformity on the Elsa Dal Formation (Fig. 91). Here the boundary is taken at the base of the first wave ripple-laminated very finegrained sandstone bed of the Wimans Bjerg Formation.

The Wimans Bjerg Formation is conformably overlain by the Britta Dal Formation (Figs 97. 101). The boundary is arbitrarily defined by an upward decrease in coarse siltstones with wave ripple-lamination from $c$. $25 \%$ in the upper part of the Wimans Bjerg formation to $c .5 \%$ in the Britta Dal Formation, or by an upward change from siltstone with concretionary and stromatolitic carbonate (Wimans Bjerg Formation) to finegrained sandstone with calcrete nodules (Britta Dal Formation) at northeastern Obrutschew Bjerg. The upward disappearance of green siltstones near the boundary also marks the transition to the Britta Dal Formation and is clearly visible from a distance.

Distribution. The formation occurs on Gauss Halvø and on eastern Ymer $\emptyset$ and probably also on central Geographical Society $\emptyset$ (Figs 84, 85; Larsen, 1990b, d). A small outlier has been found in Prospektdal north of Moskusoksefjord (Larsen et al., 1989).

Geological age. The Wimans Bjerg Formation contains no fossils. The presence of Famennian fish faunas in the Aina Dal and Britta Dal Formations immediately below and above, respectively, suggests a Famennian age also for this formation (Friend et al., 1983).
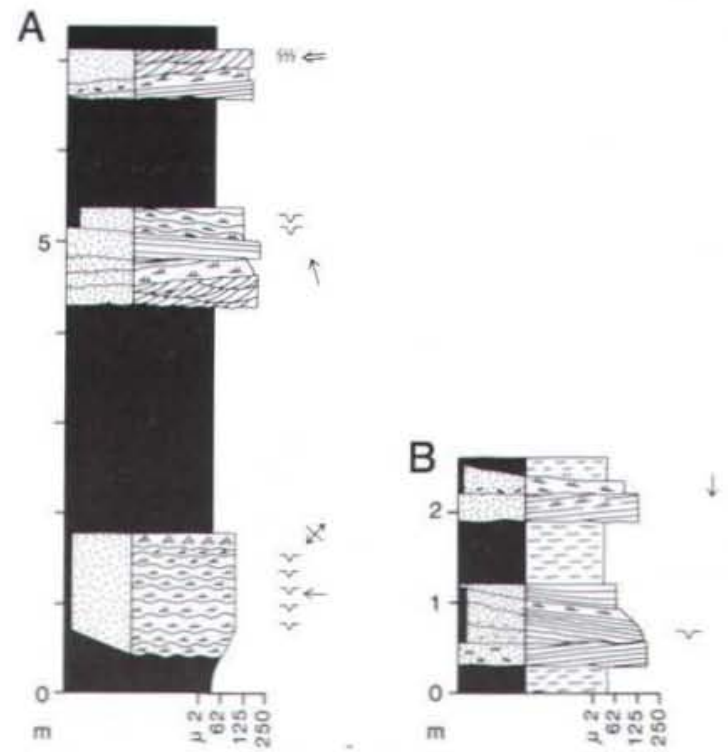

Fig. 100. Facies logs from the Britta Dal Formation at type section 30 (Figs 85.89 ) at Stensiô Bjerg. A was measured $c$. $150 \mathrm{~m}$ and $\mathrm{B} \mathrm{C.} 100 \mathrm{~m}$ below the top of the formation. Legend: Plate 2. Fossils of the tetrapod Acanthostega were found in the lower sandstone body in B in 1987 (Bendix-Almgreen et al. 1988, 1990). 


\section{Britta Dal Formation}

History. The Britta Dal Formation was defined by Nicholson \& Friend (1976) as part of their 'Remigolepis Group' ('Mount Celsius Supergroup') (Fig. 5). The formation forms part of Kulling's (1931, fig. 1) upper red sandstone series (Fig. 3). Bütler (1935, 1954, 1959. $1961)$ included it in the 'Mount Celsius Series' and Koch \& Haller (1971) mapped it as such being equivalent to the 'Remigolepis Series, division c' of Säve-Söderbergh (1934; Figs 3, 4).

Name. After the valley, Britta Dal, on the southwest coast of Gauss Halvo (Fig. 84).

Type and reference sections. The type section is the mountain. Stensiô Bjerg on the central southwest coast of Gauss Halvo (section 30, Figs 85, 89). Reference section is from SW Celsius Bjerg (section 33. Figs 85 , 89). The detailed sections (Fig. 100) are from Stensiö Bjerg,

Thickness. Maximum thickness of $c .500 \mathrm{~m}$ is reached on the south coast of Gauss Halvø. The thickness decreases to the north and cast (Larsen 1990b, d). On Celsius Bjerg the thickness of the unit has been measured as $c .450 \mathrm{~m}$.

Lithology and sedimentary structures. The Britta Dal Formation is composed of alternating siltstone and very fine to fine-grained sandstone (Fig. 100). The proportion of siltstone to sandstone varies highly, e.g. c. $50 \%$ siltstone on Celsius Bjerg and c. $90 \%$ on Stensiö Bjerg. The rocks are mainly dark red, alternating with up to $25 \%$ dark grey and (mainly in the upper part of the formation) green siltstones. The alternation is on a metre to 10 metres scale. The siltstones are generally massive or brecciated, with occasional wave ripple-lamination. Desiccation cracks are common. The sandstones are mainly cross-laminated and parallel laminated and commonly display lateral accretion bedding.

Depositional environments and palaeocurrents. This formation was deposited as point bars (sandstones) in shallow meandering fluvial channels, and in extensive flood basins (siltstones). The discharge was highly fluctuating to ephemeral (Bendix-Almgreen et al., 1990; Olsen. 1993). Palaeocurrents were difficult to obtain but generally palaeoflow towards the north is inferred (Olsen. 1993).

Boundaries. The Britta Dal Formation rests conformably on the Wimans Bjerg Formation (Figs 87. 97, 101). The boundary is arbitrarily defined by an upward decrease in coarse siltstones with wave ripple-lamination from c. $25 \%$ in the upper part of the Wimans Bjerg Formation to c. $5 \%$ in the Britta Dal Formation. This is commonly associated with disappearance of green siltstones (occurring in the uppermost part of the Wimans Bjerg Formation), clearly visible in the field. At the easternmost localities the transition is defined by an upward change from siltstone with concretionary and stromatolitic carbonate (Wimans Bjerg Formation) to
Fig. 101. Southwestern part of the mountain Stensio Bjerg (Fig. 84), Gauss Halvø, facing Kejser Franz Joseph Fjord. The mountain ridge to the right (east) is the type section for the Stensiö Bjerg Formation (SB) and reference section for Obrutschew Bjerg Formation (OB) and Harder Bjerg Formation (HB), and forms part of the composite section 30 (Figs 85, 89). Also visible are the Aina Dal Formation (AD). Wimans Bjerg Formation (WB) and Britta Dal Formation (BD). Note the coast parallel fault. Height of mountain is $c$. $1200 \mathrm{~m}$.

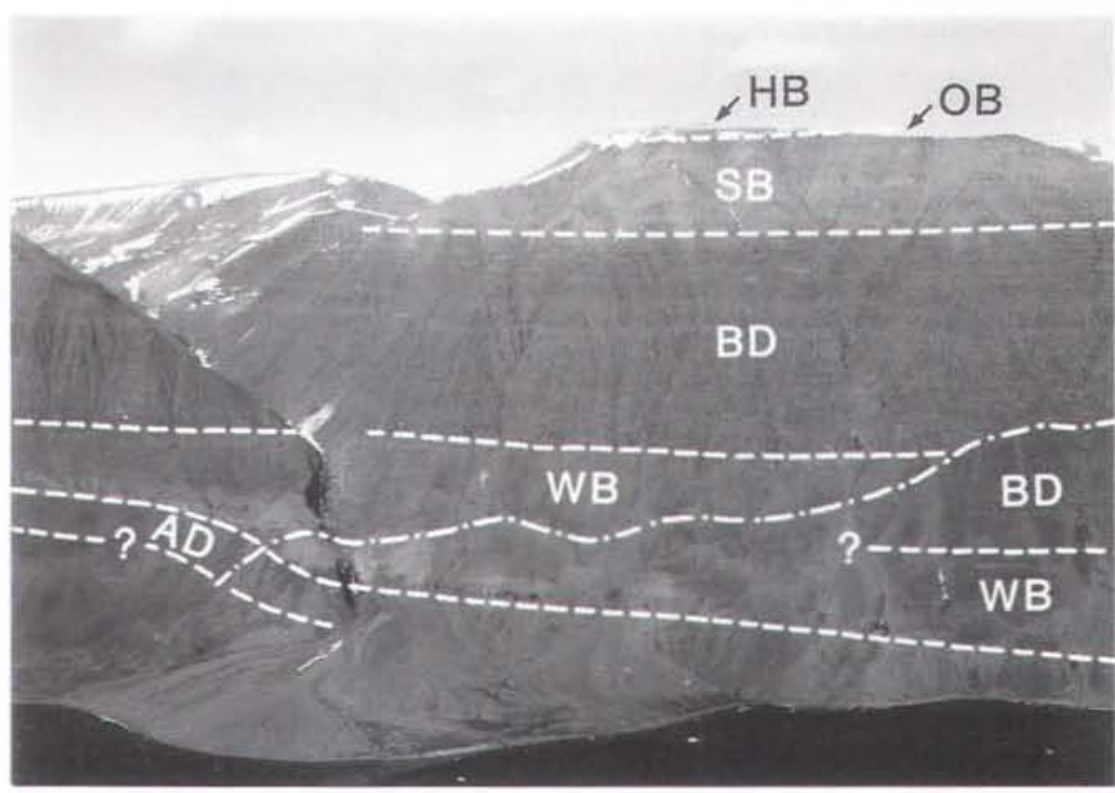



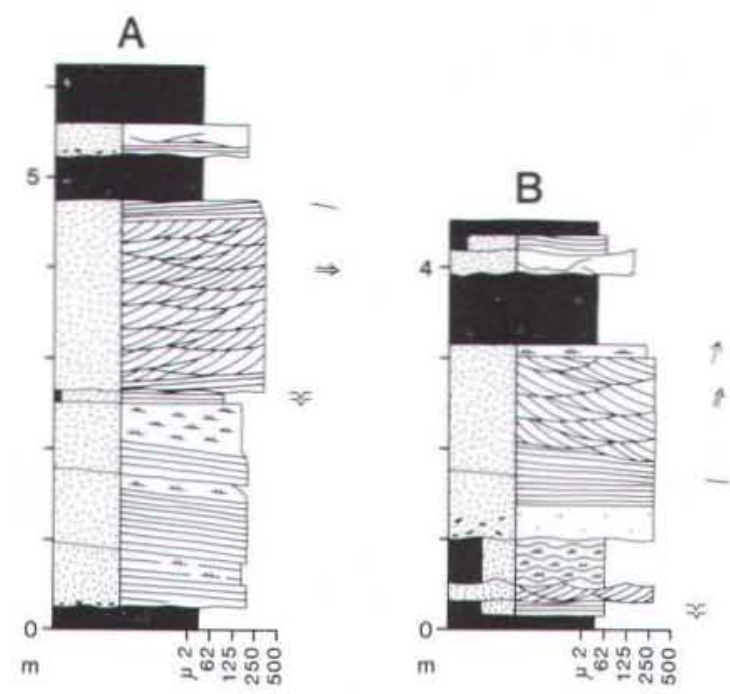

fine-grained sandstone with calcrete nodules (lower part of Britta Dal Formation).

The upper part of the formation is gradually transitional to the Stensiö Bjerg Formation (Figs 87, 97, 101). The boundary is taken at the base of the first fine to medium-grained greenish or yellowish grey sandstone bed of the Stensiö Bjerg Formation.

Distribution. The formation crops out on Gauss Halvø and on Celsius Bjerg, Ymer $\emptyset$ and probably also on central Geographical Society $\emptyset$ (Figs 84, 85, 87; Larsen. 1990b, d). A small outlier has been found in Prospektdal north of Moskusoksefjord, being the youngest known Devonian deposit preserved in Hudson Land (Larsen et al., 1989).

Geological age. The presence of numerous fossil fish, including the tetrapod Acanthostega, indicates a Famennian age of the formation (Friend et al., 1983; BendixAlmgreen et al., 1988, 1990).

\section{Steinsö Bjerg Formation new formation}

History. The Stensiö Bjerg Formation forms part of Kulling's (1931, fig. 1) upper grey sandstone series (Fig. 3). It corresponds to the 'Artrodire Sandstone Series' (Fig. 3) of Säve-Sōderbergh (1934). Būtler (1935, 1954. 1959, 1961) included the formation in his 'Mount Celsius Series' and also Koch \& Haller (1971) indicated the formation as such on their geological map (Figs 3, 4).

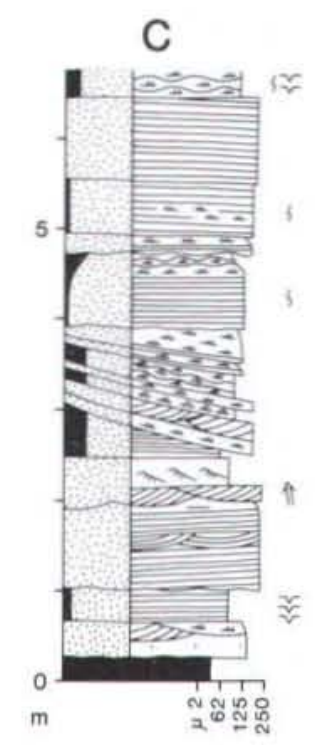

Fig. 102. Facies logs from the Stensiö Bjerg Formation at type section 30 (Figs 85, 89) at Stensiō Bjerg. The sandstone bodies exhibit lateral accretion bedding. A was measured $c$. $90 \mathrm{~m}$. B C. $150 \mathrm{~m}$ and C c. $180 \mathrm{~m}$ above the base of the formation. Legend: Plate 2

The formation forms the main part of Nicholson \& Friend's (1976) 'Grönlandaspis Group' ('Mount Celsius Supergroup') (Fig. 5). The mixture of biostratigraphic and lithostratigraphic nomenclature is unfortunate and it is suggested that the old name be abandoned.

Name. After the mountain, Stensio Bjerg, on the southwest coast of Gauss Halvø (Fig. 84).

Type and reference sections. The type section is Stensiō Bjerg (section 30 , Figs 85,89 ). The reference section is from SW Celsius Bjerg (section 33, Figs 85, 89). Detailed sections (Fig. 102) are from Stensiö Bjerg.

Thickness. The thickness of the formation in southern Gauss Halvø has been measured as c. $300 \mathrm{~m}$ (Larsen. 1990b, d). On Celsius Bjerg the thickness of the unit is estimated at c. $250 \mathrm{~m}$.

Lithology and sedimentary structures. The formation is dominated by fine and medium-grained, yellowish, greenish and reddish grey sandstones. Red, grey, green and black siltstones are associated with the sandstones (Fig. 102). A gross upward increase in the proportion of sandstone to siltstone from $c .30 \%$ to $c .90 \%$ is observed at most localities. Sandstones generally occur as $1-5 \mathrm{~m}$ thick tabular bodies exhibiting lateral accretion bedding dominated by parallel lamination and trough cross-bedding. At one locality, between Harder Bjerg and Obrutschew Bjerg, $10 \mathrm{~m}$ of alternating thin grey sandstone and siltstone beds with desiccation cracks form the whole formation. One black silty shale unit of less than $1 \mathrm{~m}$ thick occurs $c .40 \mathrm{~m}$ below the top of the formation. 
Depositional environments and palaeocurrents. The sand was deposited as point bars in meandering rivers and, to a lesser degree, as crevasse splays. The siltstones represent the flood basins, associated with the rivers. The alternating sandstones and siltstones also represent flood basins or ephemeral streams. The black silty shale unit is interpreted as a flood basin lake deposit (Olsen. 1993). Palaeocurrents from the point bar deposits indicate northward transport directions (Olsen, 1993).

Boundaries. The lower part of the formation is gradually transitional to the underlying Britta Dal Formation (Figs 87, 97, 101). The boundary is placed at the base of the first fine to medium-grained greenish or yellowish grey sandstone bed of the Stensiö Bjerg Formation. The upper boundary of the formation is taken at the base of the first black shale or associated grey mudstone or black limestone unit of the succeeding Obrutschew Bjerg Formation, resting on grey pebbly sandstones (Celsius Bjerg) or alternating very fine sandstones and siltstones (Gauss Halvø) of the Stensiö Bjerg Formation.

Distribution. The Stensiō Bjerg Formation crops out on south central Gauss Halvø and on Celsius Bjerg, Ymer $\emptyset$ (Larsen, 1990b, d). It probably also occurs in central Geographical Society $\emptyset$, but it has not been examined by us in this area (Figs 84, 85, 87).

Geological age. Abundant fossil fish, including Grönlandaspis, are found in this formation. They may in- dicate an uppermost Famennian (Devonian) or lowermost Tournaisian (Carboniferous) age (Jarvik, 1959; Bütler, 1961: Nicholson \& Friend, 1976: Friend et al., 1983).

\section{Obrutschew Bjerg Formation new formation}

History. This formation was described by Sãve-Söderbergh (1933, p. 20 \& p. 31) as part of his Arthrodire Sandstone Series (Fig. 3) and by Nicholson \& Friend (1976, p. 96) as part of their Grönlandaspis Group (Fig. 4). It was included in the 'Mount Celsius Series' (Fig. 4) on the map of Koch \& Haller (1971).

Name. After the mountain, Obrutschew Bjerg, in southeastern Gauss Halvø, forming the easternmost mountain of the Hjelmbjergene (Fig. 85).

Type and reference sections. The type section is from Obrutschew Bjerg (section 32, Figs 85, 89, 103). Reference sections are from Stensiö Bjerg (section 30, Figs 85,89 ) and Celsius Bjerg (section 33, Figs 85, 89). Detailed sections (Fig. 104) have been measured at all localities.

Thickness. In the outcrop area the formation varies in thickness between $4 \mathrm{~m}$ at the type locality and $6 \mathrm{~m}$ in Stensiö Bjerg. In Celsius Bjerg the formation measures $5 \mathrm{~m}$ in thickness.
Fig. 103. Outcrop of the Obrutschew Bjerg Formation at type section 32 (Figs 85, 89) at the northern part of Obrutschew Bjerg, Gauss Halvø. Black shales (SH) are interbedded with a more massive black limestone (L). Backpack in foreground for scale.

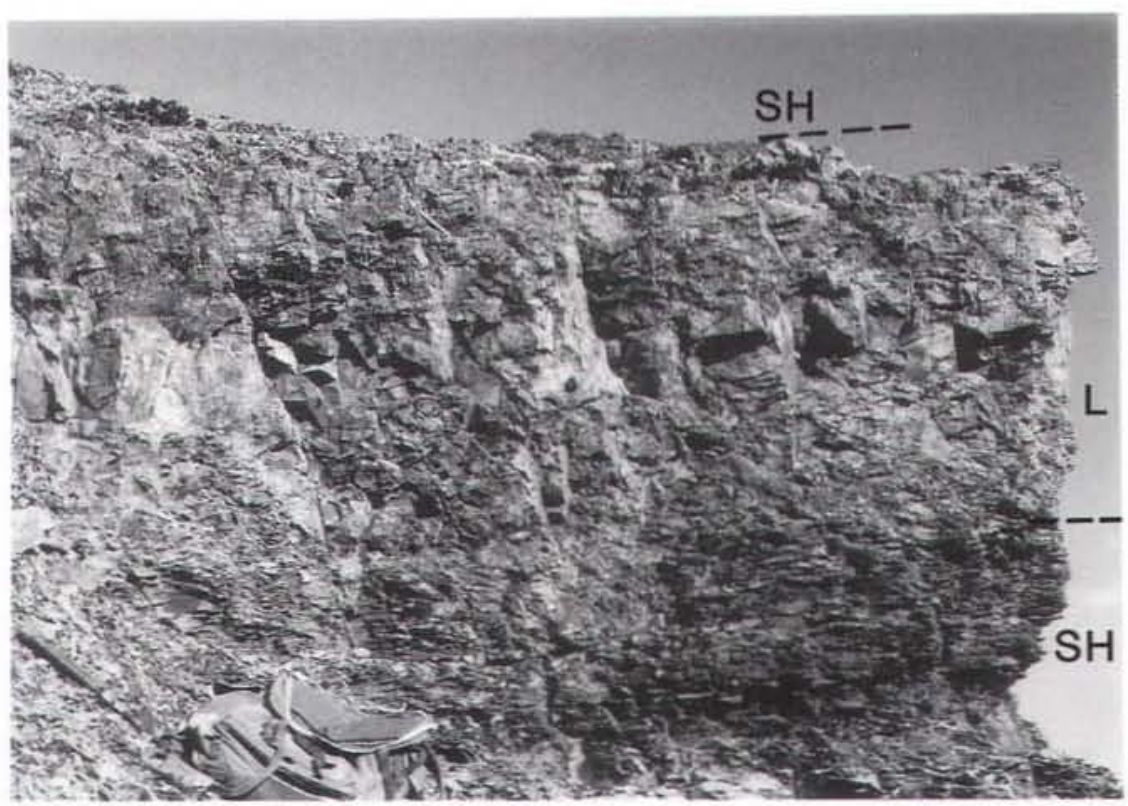




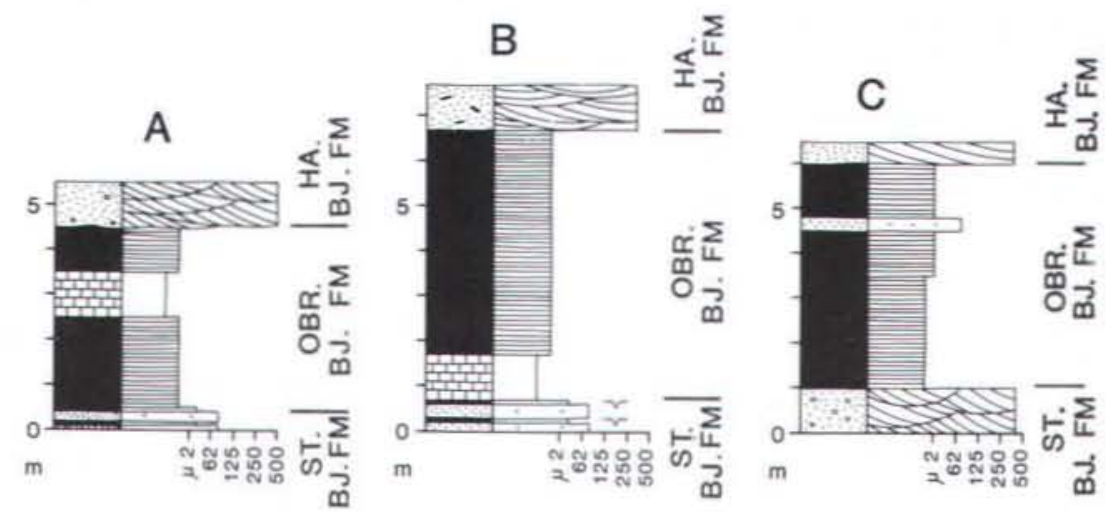

Fig. 104. Facies logs from the Obrutschew Bjerg Formation at three localities. A is from type section 32 (Figs 85,89 ) at the northern part of Obrutschew Bjerg. B was measured in reference section 30 at Stensiö Bjerg and C was measured at reference section 33 (Figs 85, 89) at SW Celsius Bjerg. All sections show the dominance of black shales in the formation. The Obrutschew Bjerg Formation is underlain by the Stensiö Bjerg Formation and overlain by the Harder Bjerg Formation. Legend: Plate 2.

Lithology. The formation is dominated by black shale, with associated black limestone, grey mudstone and red sandstone (Figs 103, 104). The shale and limestone are bituminous. At the type locality the formation is composed of $2 \mathrm{~m}$ of calcareous black shale overlain by $1 \mathrm{~m}$ of non-calcareous black limestone and $1 \mathrm{~m}$ of black shale. At Stensiö Bjerg the formation is composed of 1 $\mathrm{m}$ of black limestone succeeded by $5 \mathrm{~m}$ of black shale. At Celsius Bjerg the formation is composed of $2.5 \mathrm{~m}$ of black shale overlain by $2.5 \mathrm{~m}$ of grey mudstone with a 30 $\mathrm{cm}$ thick red very fine sandstone bed. At the type locality solid bitumen occurs as fracture fillings in the limestone.

Depositional environments. The formation was deposited in a lake, generally characterized by anaerobic conditions (Olsen, 1993).

Boundaries. The lower boundary of the formation is taken at the base of the first black shale or black limestone bed overlying alternating grey sandstones and siltstones with desiccation cracks of the Stensiö Bjerg Formation (type locality and Stensiö Bjerg) or overlying grey pebbly sandstones of the Stensio Bjerg Formation (Celsius Bjerg). The top of the formation is taken at the top of the uppermost black shale, black limestone or grey mudstone bed, overlain by grey, red or white sandstones of the Harder Bjerg Formation.

Distribution. The Obrutschew Bjerg Formation crops out in south central Gauss Halvo and on Celsius Bjerg, Ymer Ø (Figs 84, 85, 87).

Geological age. No age diagnostic fossils have been found in this formation. A probable Famennian or lowermost Tournaisian age is, however, indicated by the presence of Holoptychius and Grönlandaspis in the underlying Stensiö Bjerg Formation and overlying Harder Bjerg Formation (Jarvik, 1959; Bütler, 1961; Nicholson \& Friend, 1976; Friend et al., 1983). Plant fossils found by us are preserved as silvery films, lacking details. They include isolated pinnules of Sphenopteris-type, but insufficient details are available to distinguish between Archaeocalamites (first recorded in Late Devonian) and the Carboniferous Calamites. The plants thus indicate that the unit can be no older than Frasnian, but could also be Carboniferous (D. Edwards, written communication, 1988).

\section{Harder Bjerg Formation \\ new formation}

History. This formation was the uppermost part of Nicholson \& Friend's (1976) 'Grönlandaspis Group' and corresponds to the uppermost Red Sandstone Series of
Kulling (1931) and the 'Upper Sandstone Complex' of Sãve-Söderbergh (1934). It was included in Bütler's (1935, 1954, 1959, 1961) 'Mount Celsius Series' and 
indicated as such on the map of Koch \& Haller (1971) (Figs 3, 4).

Name. After the mountain, Harder Bjerg, on central Gauss Halvø (Fig. 85).

Type and reference sections. The type section is from Celsius Bjerg on eastern Ymer $\emptyset$ (section 33, Figs 87, 89). Reference sections were measured at Stensiö Bjerg (section 30, Figs 85, 89) and N Obrutschew Bjerg (section 32, Figs 85, 89). No detailed sectioning was carried out.

Thickness. The formation represents the uppermost preserved units of the Devonian (or Carboniferous) deposits at the summits of Stensiō Bjerg, Wimans Bjerg and Nathorst Bjerg (c. $50 \mathrm{~m}$; Figs 84, 101), the area between Obrutschew Bjerg and Harder Bjerg (c, $200 \mathrm{~m}$; Fig. 85) and on the summit of Celsius Bjerg (c. $150 \mathrm{~m}$; Fig. 87). South of Rudbeck Bjerg on Geographical Society $\emptyset$ the unit is thought to form more than $200 \mathrm{~m}$, but it has not been examined in the field (Fig. 85).

Lithology and sedimentary structures. The formation is dominated by trough cross-bedded fine to coarsegrained sandstones, sometimes pebbly (Fig. 105). The rocks are bright red, grey and white. The red rocks are commonly characterized by trough cross-bedding with sets 1-2 $\mathrm{m}$ thick and lack of pebbles. Rarely green, grey and red siltstones also occur. The formation is generally poorly exposed.

Depositional environments and palaeocurrents. The majority of red pebble free sandstones are of aeolian dune origin, reflecting winds blowing from the southeast $(\mathrm{Ol}$ sen, 1993). The pebbly sandstones and the siltstones are of fluvial origin: braided rivers and ephemeral streams (Olsen, 1993). Palaeocurrents are sparse but generally trend southwestwards.

Boundaries. The lower boundary of the formation is placed at the top of the black shale and associated grey
Fig. 105. Bedding characteristics of the aeolian sandstones in the Harder Bjerg Formation. The photograph was taken near the summit of the mountain Stensiō Bjerg (Fig. 84), Gauss Halvø, in reference section 30 (Figs 85, 89).

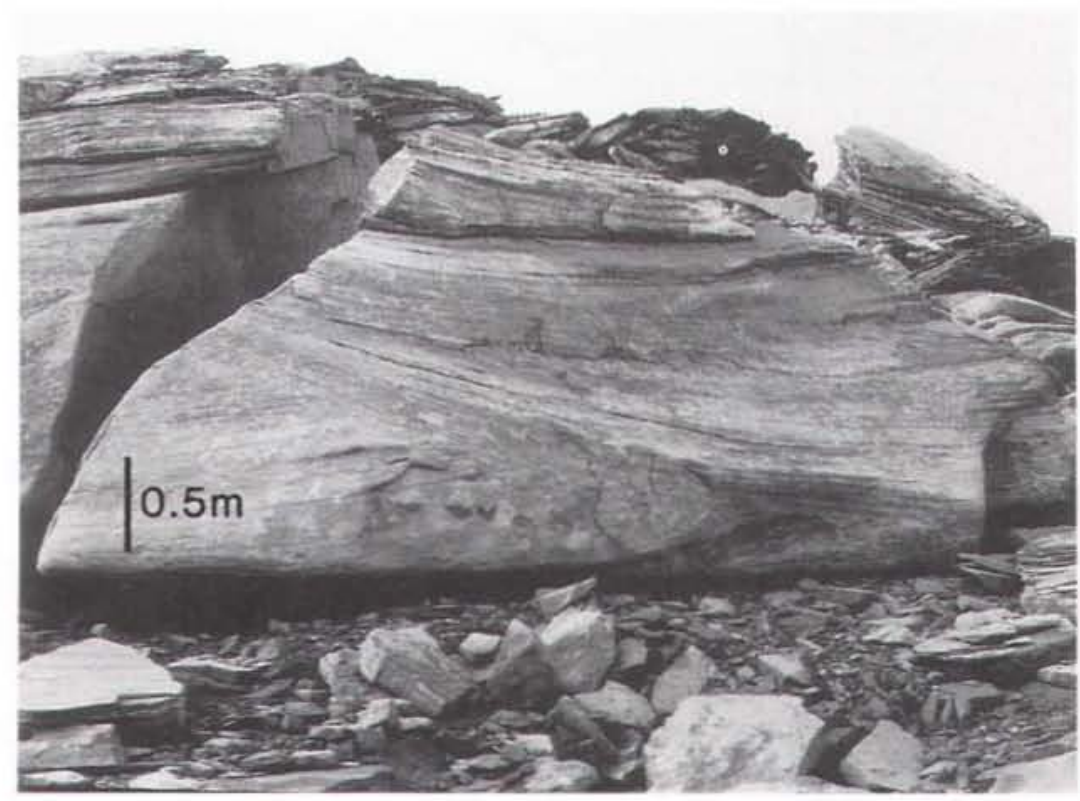


mudstone or black limestone of the underlying Obrutschew Bjerg Formation. The top of the formation is not exposed within the study area.

Distribution. The Harder Bjerg Formation always occurs as a mountain top cover. It forms the top of the mountains between Harder Bjerg and Obrutschew Bjerg (Fig. 85), and the top of Stensiō Bjerg, Wiman Bjerg and Nathorst Bjerg, Gauss Halvø (Fig. 84; Larsen. 1990b. d). It also forms the top of Celsius Bjerg on Ymer $\emptyset$ (Fig. 87), and probably occurs in central parts of Geographical Society $\emptyset$ south of Rudbeck Bjerg (Fig. 85; Larsen, 1990a).

Geological age. The presence of Holoptychius and Grönlandaspis indicate an uppermost Famennian (Devonian) or lowermost Tournaisian (Carboniferous) age (Jarvik. 1950; Bütler, 1961; Nicholson \& Friend, 1976; Friend et al., 1983).

\section{Acknowledgements}

The fieldwork forming the basis of this report was carried out in 1986. 1987 and 1988 during the general studies of basin development and onshore hydrocarbon potential in North-East Greenland undertaken by the Geological Survey of Greenland (GGU) in the years 1986-1990. The study was financed partly by the Carisberg Foundation and GGU (H. O.) and by the Mineral Resources Administration for Greenland. Ministry of Energy (P.-H. L. and H. O.). All logistical aspects of the fieldwork were organized by GGU and we are especially thankful to C. Marcussen, N. Henriksen and I. Olsen for their field support. We are thankful to P. F. Friend and W. S. Watt for critically reviewing the manuscript. A. Heilman. K. Zinck Jorgensen, F. O. Rasmussen, H. F. Jepsen, H. Nohr-Hansen. J. Bojesen-Koefoed and U. G. Wilken are thanked for good company in the field. We are grateful to S. E. Bendix-Almgreen and D. Edwards for identification of our fossil fauna and flora assemblages. Finally, we thank J. Halskov for drafting the many figures, J. Lautrup for photographic assistance and $\mathrm{V}$. Hermansen for typing the manuscript.

The vertical aerial photographs are published with the courtesy of Kort- og Matrikelstyrelsen. Denmark (permission A.200/87).

\section{References}

Alexander-Marrack. P. D. \& Friend, P. F. 1976: Devonian sediments of East Greenland. III. The eastern sequence, Vilddal Supergroup and part of the Kap Kolthoff Supergroup. Meddr Gronland 206(3). 22 pp.

Allen, K. C, 1972: Devonian megaspores from East Greenland: their bearing on the development of certain trends. Rev. Palaeobotn. Palynol. 14, 7-17.

Bendix-Almgreen, S. E. 1976: Palaeovertebrate faunas of Greenland. In Escher. A. \& Watt, W. S. (ed.) Geology of Greenland, 536-573. Copenhagen: Geol. Surv. Greenland.

Bendix-Almgreen, S. E.. Clack, J. A. \& Olsen, H. 1988: Upper Devonian and Upper Permian vertebrates collected in 1987 around Kejser Franz Joseph Fjord, central East Greenland. Rapp. Gronlands geol. Unders. 140, 95-102.

Bendix-Almgreen, S. E.. Clack, J. A. \& Olsen, H. 1990: Upper Devonian tetrapod palaeoecology in the light of new discoveries in East Greenland. Terra Nova 2, 131-137.

Bütler, H. 1935: Die Mächtigkeit der kaledonischen Molasse in Ostgrönland. Mitt. Naturforsch. Gesellschaft Schaffhausen 12. 17-33.

Bütler, H. 1954: Die stratigraphische Gliederung der mitteldevonischen Serien im Gebiet von Kap Franklin in ZentralOstgrōnland. Meddr Gronland 116(7), 126 pp.

Bütler. H. 1955: Das variscisch gefaltete Devon zwischen Dusén Fjord und Kongeborgen in Zentral-Ostgrönland. Meddr Gronland 155(1), 131 p.
Bütler, H. 1957: Beobachtungen an der Hauptbruchzone der Küste von Zentral-Ostgrönland. Meddr Gronland 160(1), 79 pp.

Bütler, H. 1959: Das Old Red-Gebiet am Moskusoksefjord. Attempt at a correlation of the series of various Devonian areas in Central East Greenland. Meddr Gronland 160(5). $88 \mathrm{pp}$.

Bütler, H. 1961: Devonian deposits of Central East Greenland. In Raasch. G. O. (ed.) Geology of the Arctic 1, 188196. Toronto U. P.

Clack, J. A. 1988: New material of the early tetrapod Acanthostega from the Upper Devonian of East Greenland. Palaeontology 31, 699-724.

Clack, J. A. 1989: Discovery of the earliest known tetrapod stapes. Nature 342, 425-427.

Friend, P. F., Alexander-Marrack, P. D., Nicholson, J. \& Yeats, A. K. 1976: Devonian sediments of East Greenland. I. Introduction, classification of sequences, petrographic notes. Meddr Gronland 206(1), 56 pp.

Friend, P. F., Alexander-Marrack, P. D., Nicholson, J. \& Yeats, A. K. 1976: Devonian sediments of East Greenland. II. Sedimentary structures and fossils. Meddr Gronland 206 (2), $91 \mathrm{pp}$.

Friend, P. F., Alexander-Marrack, P. F., Allen, K. C., Nicholson, J. \& Yeats, A. K. 1983: Devonian sediments of East Greenland. VI. Review of results. Meddr Grenland 206(6). $96 \mathrm{pp}$. 
Haller, J. 1971: Geology of the East Greenland caledonides, 415 pp. New York: Interscience Publishers.

Heintz, A. 1930: Oberdevonische Fischreste aus Ostgrönland. Skr. Svalbard Ishavet 30, 31-46.

Heintz, A. 1932: Beitrag zur Kenntnis der devonischen Fischfauna Ostgrönlands. Skr. Svalbard Ishavet 42, 1-27.

Jarvik, E. 1948: Note on the Upper Devonian vertebrate fauna of East Greenland and the age of the Ichthyostegid Stegocephalian. Arkiv Zool., Stockh. 41A(13), 1-8.

Jarvik, E. 1950a: Note on Middle Devonian Crossopterygians from the eastern part of Gauss Halvø, East Greenland. With an appendix: An attempt at a correlation of the Upper Old Red Sandstone of East Greenland with the marine sequence. Meddr Gronland 149(6), $20 \mathrm{pp}$.

Jarvik, E. 1950b: Middle Devonian vertebrates from Canning Land and Wegeners Halvø (East Greenland). Part II. Crossopterygii. Meddr Grønland 96(4), 132 pp.

Jarvik, E. 1952: On the fish-like tail in the Ichthyostegid Stegocephalians. With descriptions of a new Crossopterygian from the Upper Devonian of East Greenland. Meddr Grønland 114(12), $90 \mathrm{pp}$.

Jarvik, E. 1955: The oldest tetrapods and their forerunners. Sci. Monthly 80, 141-154.

Jarvik, E. 1961: Devonian vertebrates. In Raasch, G. O. (ed.) Geology of the Arctic 1, 197-204. Toronto U.P.

Jarvik, E. 1963: The fossil vertebrates from East Greenland and their zoological importance. Experientia 19, 184-289.

Johansson, A. E. V. [Jarvik, E.] 1935: Upper Devonian fossiliferous localities in Parallel Valley on Gauss Peninsula, East Greenland, investigated in the summer of 1934. Meddr Grønland 96(3), 37 pp.

Kelly, S. B. \& Olsen, H. 1993: Terminal fans - a review with reference to Devonian examples. Sediment. Geol. (in press).

Koch, L. 1929a: The geology of East Greenland. Meddr Grønland 73(2), 1-204.

Koch, L. 1929b: Stratigraphy of Greenland. Meddr Grønland 73(2), 205-320.

Koch, L. \& Haller, J. 1971: Geological map of East Greenland $72^{\circ}-76^{\circ} \mathrm{N}$ Lat. $(1: 250,000)$. Meddr Grønland 183, 26 pp.

Kulling, O. 1930: Stratigraphic studies of the geology of Northeast Greenland (Preliminary report). Meddr Gronland $\mathbf{7 4}$ (13), 317-346.

Kulling, O. 1931: An account of the localities of the Upper Devonian vertebrate finds in East Greenland in 1929. Meddr Grønland 86(2), 14 pp.

Larsen, P.-H. 1990a: Geological map (1:100 000) of the Devonian basin, North-East Greenland. Unpubl. intern. GGU rep., 6 pp., 3 maps.

Larsen, P.-H. 1990b: Geological, structural contour and isopach maps (1:50 000) of the Upper Devonian Celsius Bjerg Group on eastern Gauss Halvø, North-East Greenland. Unpubl. intern. GGU rep., 6 pp., 12 maps.

Larsen, P.-H. 1990c: Structural contour and isopach maps (1:50 000) of the Upper Devonian Kap Graah Group on western Gauss Halvø, North-East Greenland. Unpubl. intern. GGU rep., 6 pp., 6 maps.

Larsen, P.-H. 1990d: The Devonian basin in East Greenland.
Status of structural studies, June 1990. Unpubl. intern. GGU rep., 54 pp.

Larsen. P.-H. \& Bengaard, H.-J. 1991: The Devonian basin initiation in East Greenland: a result of sinistral wrench faulting and Caledonian extensional collapse. J. geol. Soc. London 148, 355-368.

Larsen, P.-H. \& Olsen, H. 1991: The Devonian basin project, North-East Greenland - a summary. Rapp. Grønlands geol. Unders. 152, 17-20.

Larsen, P.-H., Olsen, H., Rasmussen, F. D. \& Wilken, U. G. 1989: Sedimentological and structural investigations of the Devonian basin, East Grecnland. Rapp. Gronlands geol. Unders. 145, 108-113.

Marcussen, C., Christiansen, F. G., Larsen, P.-H., Olsen, H., Piasecki, S., Stemmerik, L., Bojesen-Koefoed, J., Jepsen, H. F. \& Nøhr-Hansen, H. 1987: Studies of the onshore hydrocarbon potential in East Greenland 1986-87: fieldwork from $72^{\circ}$ to $74^{\circ}$ N. Rapp. Grønlands geol. Unders. 135, 72-81.

Marcussen, C., Larsen, P.-H., Nøhr-Hansen, H., Olsen, H., Piasecki, S. \& Stemmerik, L. 1988: Studies of the onshore hydrocarbon potential in East Greenland 1986-87: fieldwork from $73^{\circ}$ to $76^{\circ}$ N. Rapp. Grønlands geol. Unders. 140,89-95.

Maync, W. 1949: On the pre-Permian basement of the Giesecke Mountains (Gauss Peninsula), northern East Greenland. Meddr Grønland 114(2), 65 pp.

Miall, A. D. 1984: Principles of sedimentary basin analysis, 490 pp. New York: Springer Verlag.

NACSN 1983: North American Stratigraphic Code. Am. Ass. Petrol. Geol. Bull. 67, 841-875.

Nathorst, A. G. 1901: Bidrag til nordöstra Grönlands Geologi (with petrographic descriptions by H. Bäckström). Geol. Fören. Stockh. Förh. 23(207), 275-306.

Nicholson, J. \& Friend, P. F. 1976: Devonian sediments of East Greenland. V. The central sequence, Kap Graah Group and Mount Celsius Supergroup. Meddr Grønland 206(5), 117 pp.

Olsen, H. 1990: Astronomical forcing of meandering river behaviour: Milankovitc cycles in Devonian of East Greenland. Palaeogeogr. Palaeoclimatol. Palaeoecol. 79, 99-115.

Olsen, H. 1993: Sedimentary basin analysis of the continental Devonian basin in North-East Greenland, Bull. Grønlands geol. Unders. (in press)

Olsen, $\mathrm{H}$. in press: Orbital forcing on continental depositional systems - lacustrine and fluvial cyclicity in the Devonian of East Greenland. In de Boer, P. L. \& Smith, D. G. (ed.) Orbital forcing and cyclic sequences. Spec. Publ. int. Ass. Sediment.

Olsen, H. \& Larsen, P.-H. 1993: Structural and climatic controls on fluvial depositional systems - Devonian, North-East Greenland. In Marzo, M. \& Puigdefàbregas, C. (ed.) Alluvial sedimentation. Spec. Publ. int. Ass. Sediment. 17, 401423.

Orvin, A. K. 1930: Beiträge zur Kenntnis des Oberdevons Ostgrönlands. Skr. Svalbard Ishavet 30, 1-30.

Orvin, A. K. 1931: A fossil river bed in East-Greenland. Norsk geol. Tidsskr. 12, 469-474.

Säve-Sönderbergh, G. 1932a: Notes on the Devonian stratigraphy of East Greenland. Meddr Grønland 94(4), 40 pp. 
Säve-Sönderbergh, G. 1932b: Preliminary note on Devonian Stegocephalians from East Greenland. Meddr Gronland 94 (7), $107 \mathrm{pp}$.

Säve-Sönderbergh, G. 1933: Further contributions to the Devonian stratigraphy of East Greenland, I. Results from the summer expedition 1932. Meddr Gronland 96(1), 40 pp.

Säve-Sönderbergh, G. 1934: Further contributions to the Devonian stratigraphy of East Greenland, II. Investigations on Gauss Peninsula during the summer of 1933. With an appendix: Notes on the geology of the Passage Hills (East Greenland). Meddr Gronland 96(2), $74 \mathrm{pp}$.

Säve-Sönderbergh, G. 1935: On the dermal bones of the head in Labyrinthodont Stegocephalians and primitive reptilia, with special reference to Eotriassic Stegocephalians from East Greenland. Meddr Grønland 98(3), 211 pp.

Säve-Sönderbergh, G. 1937: On the Paleozoic stratigraphy of Canning Land, Wegener Peninsula, and Depot Island (East Greenland). Meddr Gronland 96(5), 41 pp.

Stensiö, E. A. 1931: Upper Devonian vertebrates from East Greenland, collected by the Danish Greenland Expeditions in 1929 and 1930. Meddr Grønland 86(1), $212 \mathrm{pp}$.

Stensiö, E. A. 1934: On the Placodermi of the Upper Devonian of East Greenland. I. Phyllolepida and Arthrodira. Meddr Gronland 97(1), 58 pp.
Stensiö, E. A. 1936: On the Placodermi of the Upper Devonian of East Greenland. Supplement to Part I. Meddr Grønland $\mathbf{9 7}(2), 52 \mathrm{pp}$.

Stensiö, E. A. 1939: On the Placodermi of the Upper Devonian of East Greenland. Second supplement to Part I. Meddr Grønland 97(3), 33 pp.

Stensiö, E. A. 1940: Über dic Fische des Devons von Ostgrönland. Mitt. naturf. Ges. Schaffhausen 16, 132-137.

Stensiö, E. A. 1948: On the Placodermi of the Upper Devonian of East Greenland. II. Antiarchi: Subfamily Bothriolepinae, with an attempt at a revision of the previously described species of that subfamily. Meddr Grønland 139.622 pp.

Stensiö, E. A. 1961: Permian Vertebrates. In Raasch. G. O. (ed.) Geology of the Arctic 1, 231-247. Toronto U.P.

Stensiö, E. A. \& Säve-Sönderbergh, G. 1938: Middle Devonian vertebrates from Canning Land and Wegener Peninsula (East Greenland). Part I. Placodermi, Ichthyodorulithes. Meddr Gronland 96(6), 38 pp.

Woodward, A. S. 1900: Notes on some Devonian fish-remains discovered by Prof. A. G. Nathorst in East Greenland. Bih. K. svenska VetenskAkad. Handl. 26(4), $10 \mathrm{pp}$.

Yeats, A. K. \& Friend, P. F. 1978: Devonian sediments of East Greenland. IV. The western sequence, Kap Kolthoff Supergroup of the Western Areas. Meddr Gronland 206(4), 112 pp. 
Plate 1

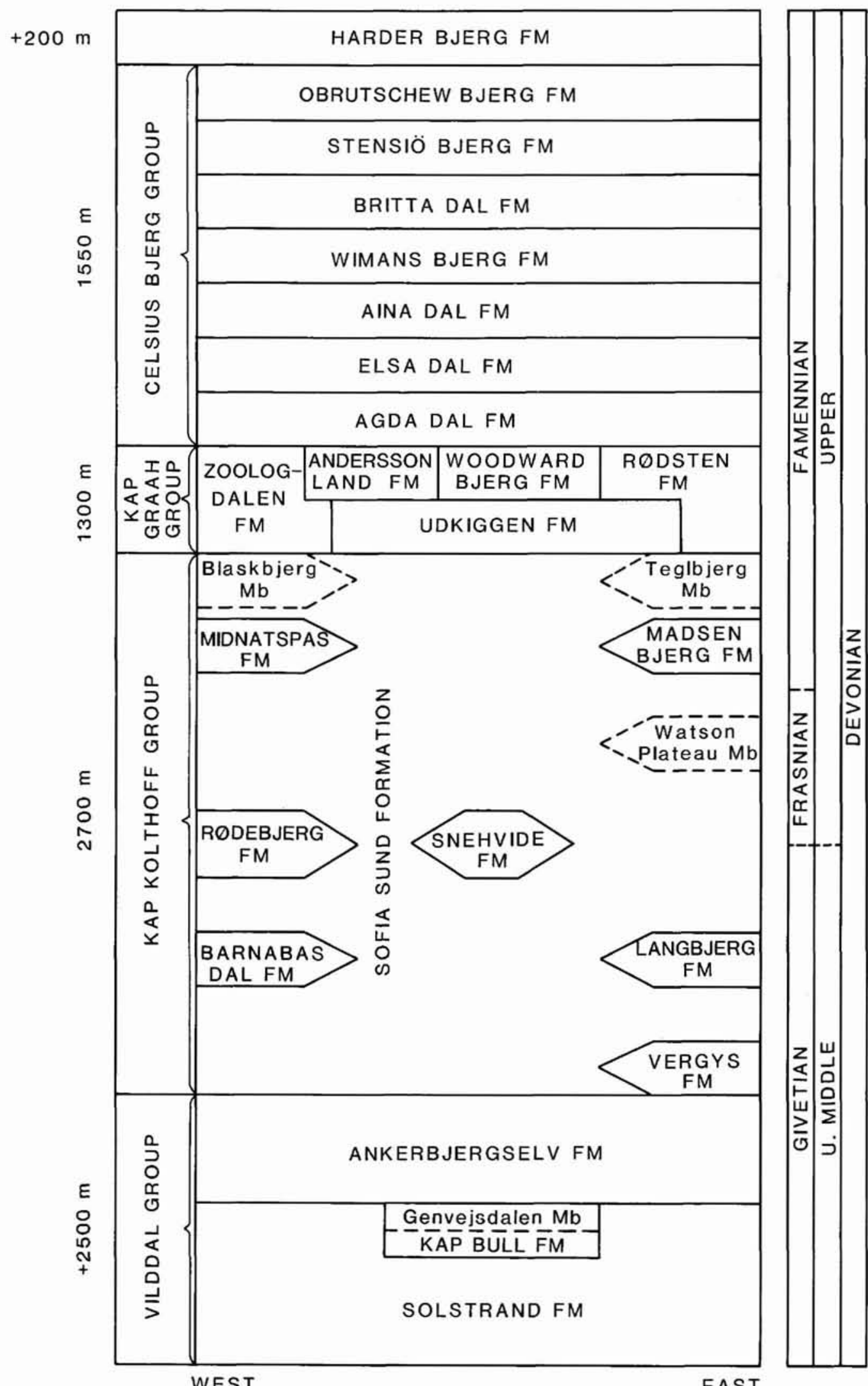

Devonian lithostratigraphy in North-East Greenland, proposed in this paper. 
Legend covering all logged sections. Facies association key refers only to the generalized sections (Figs 12, 28, 29, 30. 31, 62, 63, 89). Lithology and sedimentary structure keys refer only to the facies logs (except signature 16 which also refers to the generalized sections).

1: cross-bedded aeolian sandstones (dunes);

2: parallel laminated and irregular laminated aeolian sandstones (sandsheet/interdune);

3: interbedded siltstones and sandstones (flood basin);

4: thin-bedded sandstones (ephemeral streams);

5: tabular sandstone bodies with lateral accretion bedding (meandering rivers);

6: cross-bedded pebbly sandstones (braided rivers);

7: conglomerates (gravelly rivers/alluvial fans);

8: shales, mudstones, sandstones and limestones

(lakes);

9: limestones;

10: claystones, mudstones, siltstones and shales;

11: heterolith (claystones etc. + sandstones);

12: sandstones;

13: pebbly sandstones;

14: sandstones with intraformational clasts;

15: conglomerates;

16: volcanic rocks;

17: brecciated bedding;

18: massive bedding;

19: parallel lamination (horizontal or unidirectionally inclined);

20: wave ripple lamination (lower part) and draped lamination;

21: undifferentiated structures in claystones,

mudstones and siltstones;
22: cross-lamination (current ripples);

23: wavy bedding (with cross-lamination);

24: low-angle inclined lamination;

25: festoon cross-bedding;

26: trough cross-bedding;

27: planar cross-bedding;

28: deformed bedding;

29: diffuse lamination;

30: scour-and-fill bedding;

31: scour-and-fills forming lenticular bedding;

32: horizontal lamination (aeolian);

33: low-angle inclined lamination (aeolian);

34: windripple formsets (medium to coarse-grained sand);

35: irregular lamination (aeolian);

36: cross-bedding (aeolian);

37: current direction from cross-lamination (current ripples);

38: current direction from cross-bedding;

39: current sense from parting/streaming lineation;

40: current direction from imbrication;

41: wind direction from aeolian cross-bedding;

42: current direction from wave ripples;

43: desiccation cracks;

44: rootlets;

45: few burrows;

46: densely burrowed;

47: bioturbated;

48: calcrete nodules;

49: MPS (mean of ten largest particles, locally);

50: grain-size scale for the generalized sections;

51: grain-size scale for the detailed sections. 
Plate 2

FACIES ASSOCIATIONS
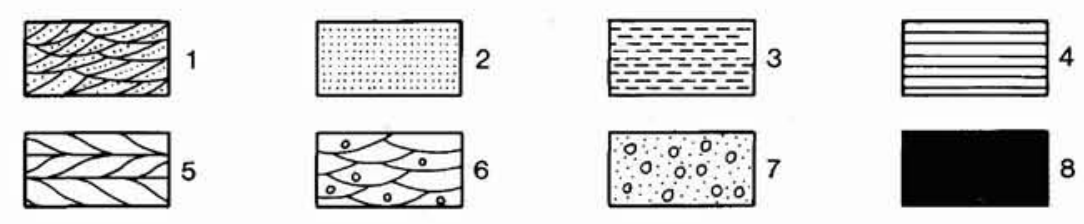

$\begin{array}{lllll}0 & 0 & 0 & 0 \\ 0 & 0 & 0 & 0 \\ 0 & 0 & 0 & 0 & 0\end{array}$

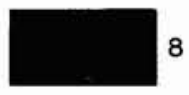

\section{LITHOLOGY}
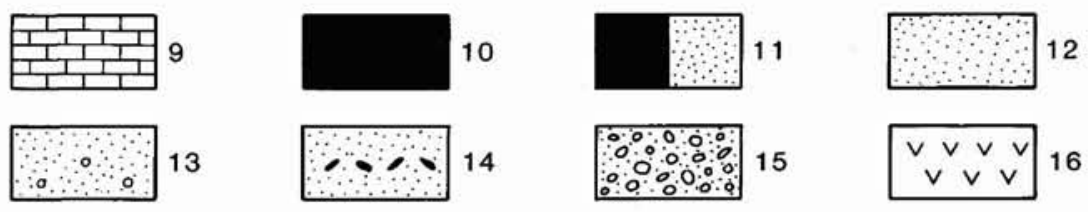

\section{SEDIMENTARY STRUCTURES}

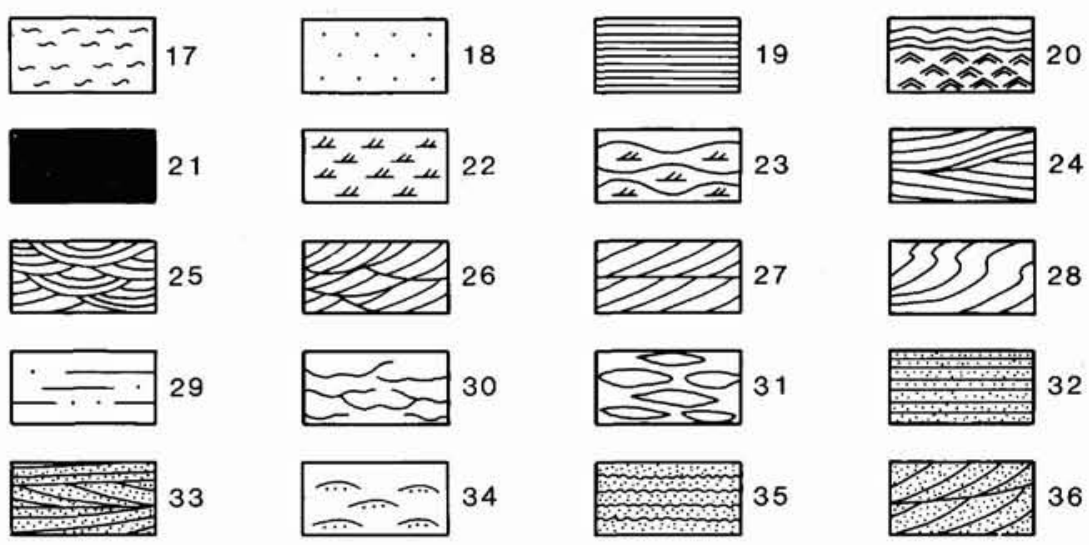

MISCELLANEOUS FEATURES

\begin{tabular}{|c|c|c|c|c|c|}
\hline$\nearrow_{37}$ & $\not 38$ & $/ 39$ & $\nearrow_{40}$ & $\boldsymbol{\gamma}_{41}$ & $\chi_{42}$ \\
\hline 人44 & $S 45$ & SS 46 & & SSS 47 & $\oplus 48$ \\
\hline & $\begin{array}{l}\text { I I I I I I I I } \\
\text { SAND } \\
\\
\\
\end{array}$ & $\begin{array}{l}150 \\
10 \\
0\end{array}$ & \multicolumn{3}{|c|}{ 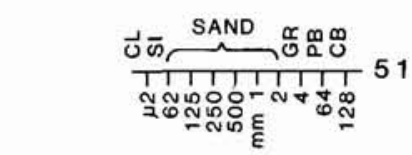 } \\
\hline
\end{tabular}

